\title{
BINDER MODIFICATION AND DEVELOPMENT FOR BRIQUETTING STEEL MILL RESIDUES
}

\section{EERC Final Report}

for the period June 2, 1997, through June 30, 1998

Prepared for:

Federal Energy Technology Center

AAD Document Control

U.S. Department of Energy

PO Box 10940, MS 921-143

Pittsburgh, PA 15236

Cooperative Agreement No. DE-FC21-93MC30098 - -53

Performance Monitor: Bob Patton

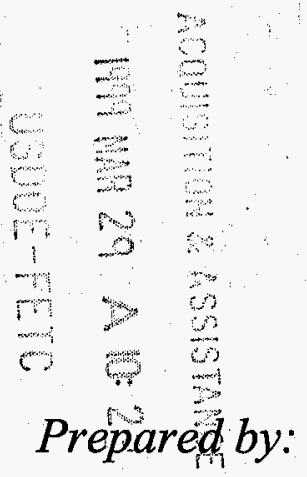

Edwin S. Olson

Energy \& Environmental Research Center University of North Dakota PO Box 9018

Grand Forks, ND 58202-9018 


\section{TABLE OF CONTENTS}

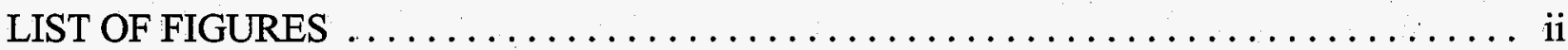

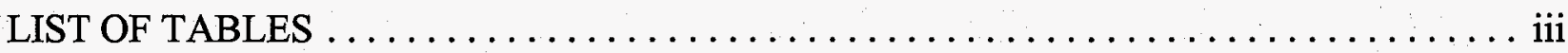

EXECUTIVE SUMMARY $\ldots \ldots \ldots \ldots \ldots \ldots \ldots \ldots \ldots \ldots \ldots \ldots \ldots \ldots \ldots$

INTRODUCTION $\ldots \ldots \ldots \ldots \ldots \ldots \ldots \ldots \ldots \ldots \ldots \ldots \ldots \ldots \ldots \ldots \ldots \ldots \ldots \ldots \ldots \ldots$

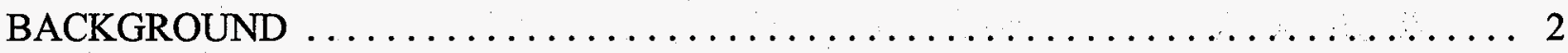

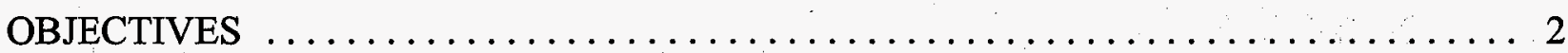

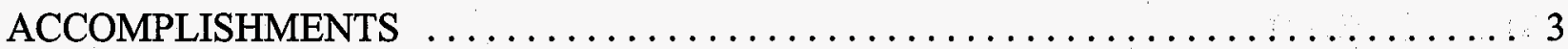

Method Development .................................. 3

Hand Press - Standard Molasses-OPC Binder $\ldots \ldots \ldots \ldots \ldots \ldots \ldots \ldots \ldots$

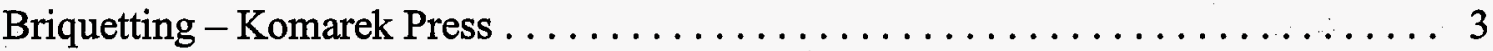

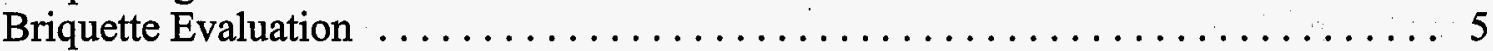

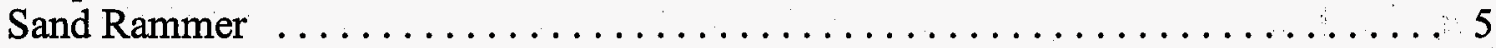

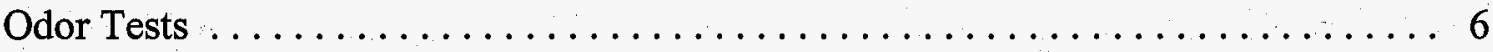

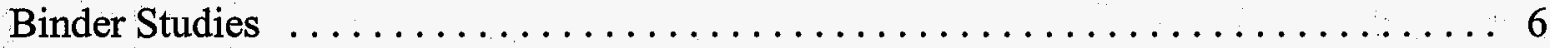

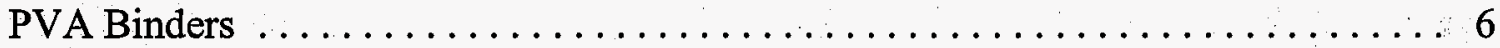

Other Polymer Binders $\ldots \ldots \ldots \ldots \ldots \ldots \ldots \ldots \ldots \ldots \ldots \ldots \ldots, 8$

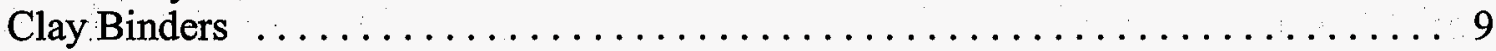

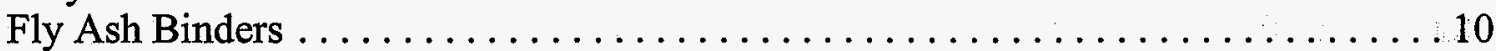

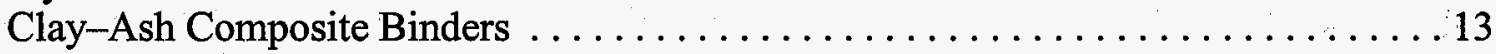

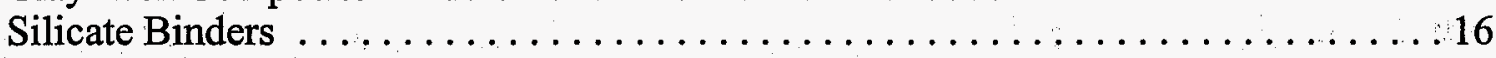

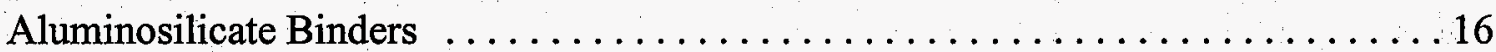

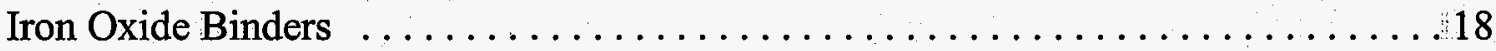

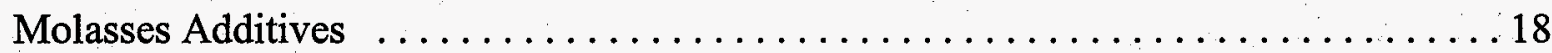

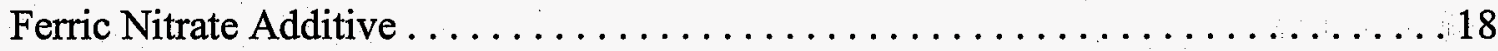

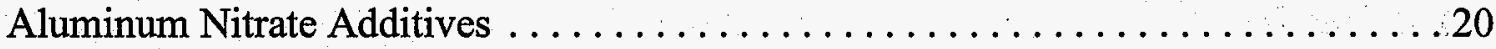

Additional Binder Compositions . . . . . . . . . . . . . . . . . . . . . . . . 20

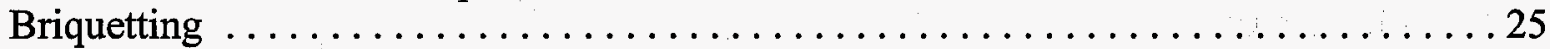

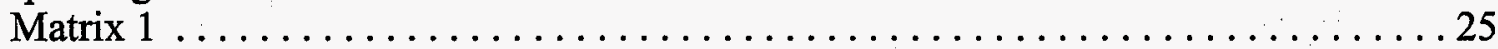

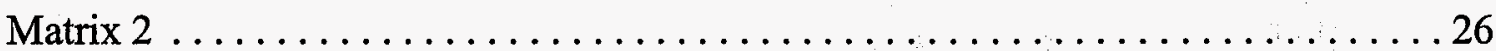

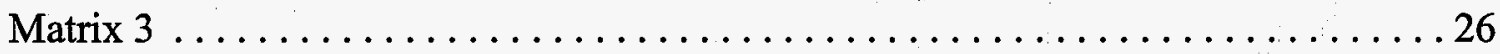

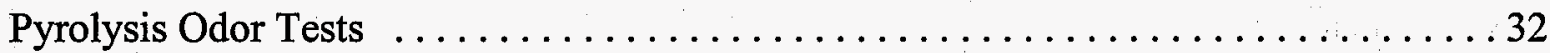

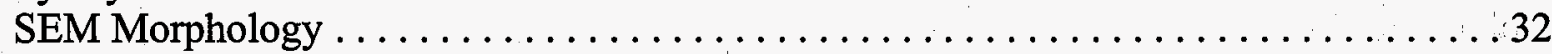

Molasses Binder Pellet Sample 980429 . . . . . . . . . . . . . . . . . . 32

Molasses-Aluminum Nitrate Binder Pellet Sample $980428 \ldots \ldots \ldots \ldots \ldots \ldots \ldots . \ldots 32$

Molasses-Ferric Nitrate Binder Pellet Sample 980427 . . . . . . . . . . . . . . . 36

Molasses-Ferric Nitrate Binder Briquette Sample $980426 \ldots \ldots \ldots \ldots \ldots \ldots \ldots . \ldots 6$

Molasses-Ferrous Sulfate Binder Pellet Sample 980430 . . . . . . . . . . . . . 40

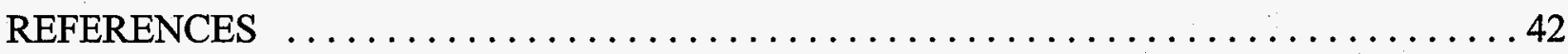

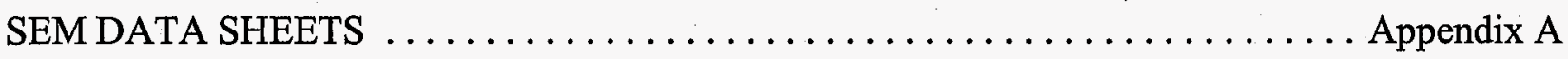




\section{LIST OF FIGURES}

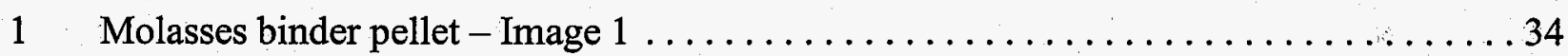

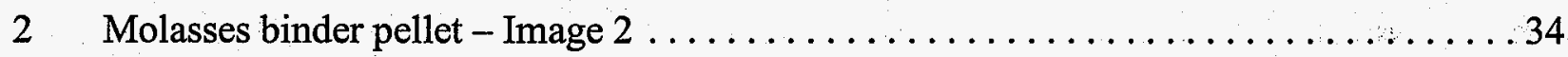

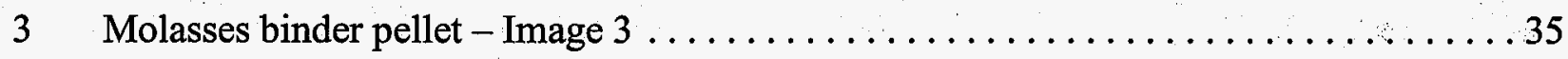

$4 \quad$ Molasses-aluminum nitrate binder pellet - Image $1 \ldots \ldots \ldots \ldots \ldots \ldots \ldots \ldots \ldots$

5 Molasses-aluminum nitrate binder pellet-Image $2 \ldots \ldots \ldots \ldots \ldots \ldots \ldots \ldots \ldots$

$6 \quad$ Molasses-aluminum nitrate binder pellet-Image $3 \ldots \ldots \ldots \ldots \ldots \ldots \ldots \ldots \ldots$

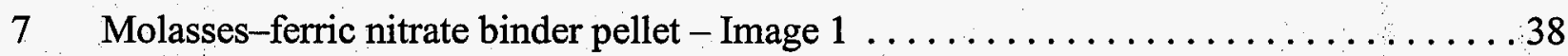

$8 \quad$ Molasses-ferric nitrate binder - Image $2 \ldots \ldots \ldots \ldots \ldots \ldots \ldots \ldots \ldots \ldots \ldots \ldots \ldots \ldots \ldots$

$9 \quad$ Molasses-ferric nitrate binder briquette - Image $1 \ldots \ldots \ldots \ldots \ldots \ldots \ldots \ldots \ldots \ldots \ldots$

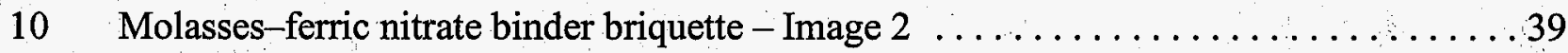

11 Molasses-ferric nitrate binder briquette - Image $3 \ldots \ldots \ldots \ldots \ldots \ldots \ldots$

12 Molasses-ferrous sulfate binder pellet - Image $1 \ldots \ldots \ldots \ldots \ldots \ldots \ldots \ldots \ldots$

13 Molasses-ferrous sulfate binder pellet - Image $2 \ldots \ldots \ldots \ldots \ldots \ldots \ldots \ldots \ldots 41$

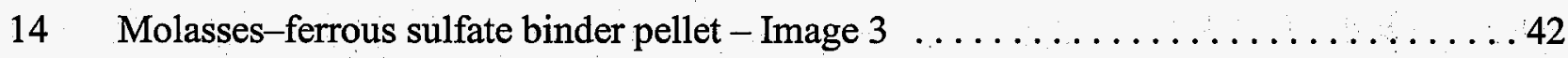




\section{LIST OF TABLES}

1 Fabrication and Strength-Testing Conditions for Steel Mill Residue Pellets $\ldots \ldots \ldots \ldots 4$

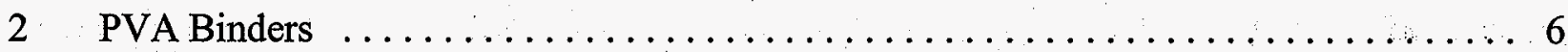

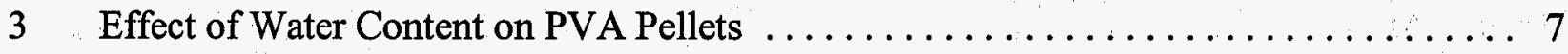

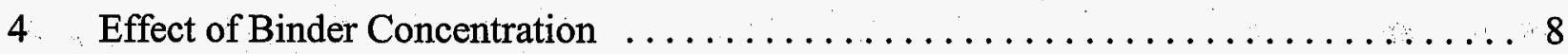

$5 \quad$ Other Macromolecular Binders $\ldots \ldots \ldots \ldots \ldots \ldots \ldots \ldots \ldots \ldots \ldots \ldots$

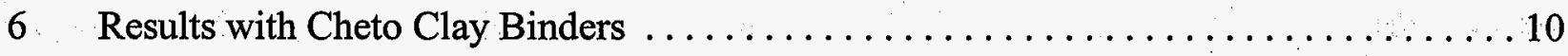

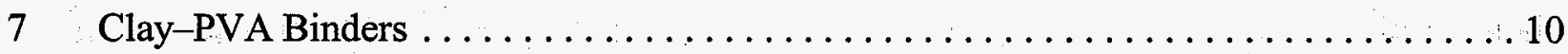

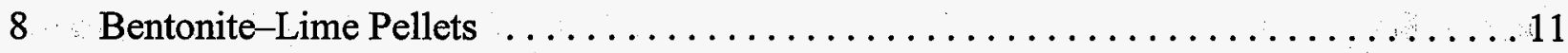

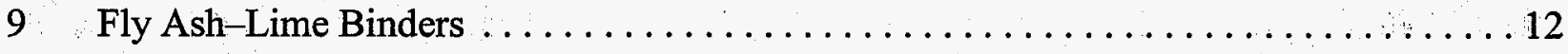

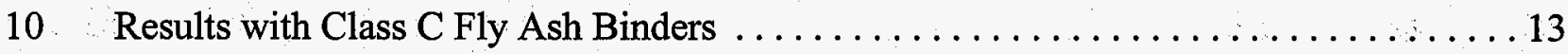

11 Results from Ash-Clay Composite Binders ...................... 14

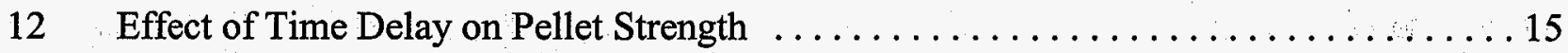

13 Pelletization of Premixed Steel Waste-Binder Mixture $\ldots \ldots \ldots \ldots \ldots \ldots \ldots \ldots \ldots$

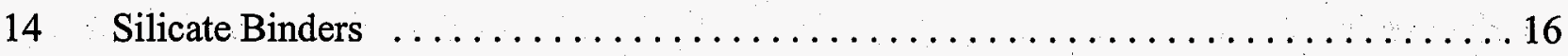

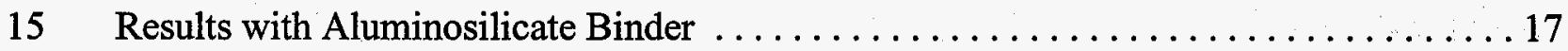

16 Results from Metal Salt Additives to Molasses Binders $\ldots \ldots \ldots \ldots \ldots \ldots \ldots \ldots$

17 Effect of Water Concentration on Molasses-Metal Salt Binders . . . . . . . . . . . . 19

18 Effect of Metal Salts and Water Concentrations on Molasses-OPC and Molasses-Lime

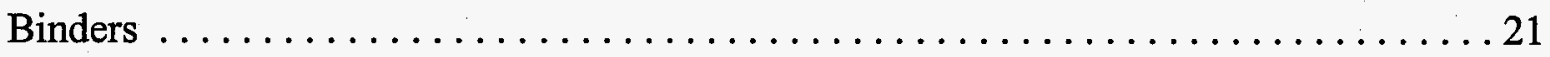

19 Effect of Molasses-Metal Salt Binder Concentrations $\ldots \ldots \ldots \ldots \ldots \ldots \ldots 22$

20 Effect of Aluminum Nitrate and Molasses Concentrations $\ldots \ldots \ldots \ldots \ldots \ldots 22$

21 Results of Tests with Molasses-Salt Binders of Various Compositions . . . . . . . 23 
22 Compositions and Conditions for Briquetting Steel Mill Waste . . . . . . . . . . 27

23 Drop-Shatter and Compressive Strength Results $\ldots \ldots \ldots \ldots \ldots \ldots \ldots$

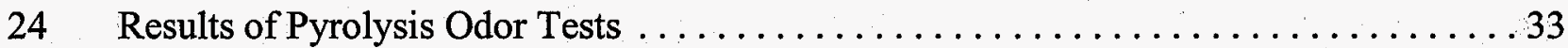




\section{BINDER MODIFICATION AND DEVELOPMENT FOR BRIQUETTING STEEL MILL RESIDUES}

\section{EXECUTIVE SUMMARY}

Alternatives to the molasses-ordinary portland cement (OPC) binder as a binder for steel mill residues were extensively investigated. A large number of binder modifications were tested using a hand pelleting apparatus to identify effective compositions. The more effective compositions were evaluated in a series of three briquetting matrices using the Komarek press. Evaluations consisted of drop tests, compression tests of green and cured pellets, and tumble tests of cured pellets. Pyrolysis odor tests were performed to determine the effects of certain compositions on the disagreeable "wet campfire" odor produced during heating of the molasses-OPC briquettes. Several scanning electron microscope (SEM) morphology studies were conducted to examine the nature of structures formed during pelleting or briquetting.

Several tacky polymers were investigated as alternatives to the molasses compositions. A water-soluble form of polyvinyl alcohol (PVA) gave high-strength pellets and briquettes at low concentrations of binder (1\%). At $0.5 \%$ PVA, the pellets failed the drop test, but compressive strengths were adequate for $0.75 \%$ PVA. Water was added to dilute the PVA and allow better coating of the steel residues. Maximum strength was achieved at $4 \%$ water. Variation in the OPC and lime concentrations had little effect on the green strength, but increased the cured strength at higher concentrations (8\%). Briquettes made with the PVA binder were of comparably high strength. Other macromolecular binders were less successful. Pyrolysis odor tests showed that the PVA pellets also generate a wet campfire odor. Cost of the PVA would be high; thus, further work with alternative organic binders was not pursued.

Clay binders were investigated using two types of clays (montmorillonite and bentonite) in various compositions, excluding molasses. The montmorillonite compositions gave poor green strengths and failed drop tests. Cured strengths were also relatively poor. Sodium bentonite-lime compositions passed the drop tests but gave poor cured compressive strengths. A clay-PVA binder composition gave a much stronger pellet.

Binders were prepared from two types of fly ashes. A fly ash obtained from Heckett Multiserve was tested with and without an alkali pretreatment. The fly ash-lime binders all failed the drop test and gave poor cured strengths. A Class $\mathrm{C}$ fly ash (Corrette) was also tested in mixtures with lime, but again all pellets failed the drop test. Cured strengths were higher but not comparable to those for the molasses-lime binders. Clays were combined with the twoashes and the composite binders tested. These all passed the drop test and developed moderate cured strengths. When the Class $\mathrm{C}$ ash was pretreated with sodium hydroxide and mixed with lime and clay, the resulting pellets were substantially stronger, but still not comparable to those'formed with molasses-lime binders.

Several other inorganic binders were investigated in combination with lime and OPC. Silicate binders were unsuccessful. Aluminosilicate binders gave better results, with survival of 
the drop test and moderate compressive strengths for cured pellets. However, the results were inferior to those from pelleting with molasses binders, and the cost of the aluminosilicate binders may be prohibitive.

The addition of salts of trivalent ions, such as aluminum and iron, to the molasses results in a dramatic decrease in the viscosity of the molasses. Consequently, the binder is able to coat or wet the steel waste much more effectively and much stronger binding occurs. Pellets produced using aluminum or ferric nitrate were about $30 \%$ stronger. Less molasses-salt binder can be used to produce the same strength as molasses alone. Other salts, such as sulfates and chlorides, were also effective in increasing the binder strength of the molasses.

Pyrolysis odor tests demonstrated that eliminating the calcium from the binder changes the wet campfire odor to are more like burned sugar and burned wood. Further addition of nitrate salts reduces the odor significantly at lower temperatures, presumably by oxidizing the odorproducing constituents.

Many kinds of component particles were identified in the SEM images of the modified molasses pellets and briquettes. Characterization of the bonding interactions were not conclusive, however, since no definite crystalline structures formed between the particles. Instead, the molasses appears to be evenly distributed around the particles. Subsequent testing will determine whether these binder systems generate noxious odors during devolatilization in the kind of reducing atmosphere that is found in the top section of a blast furnace.

Briquetting tests with the Komarek press showed that the fly ash, hydrated lime, and sodium silicate binder systems are ineffective at providing tumble resistance that approaches that of the baseline (OPC, molasses, water). Further, without the aid of a significant level of moisture, none of these binder systems provide the necessary green drop-shatter resistance that the molasses imparts. However, the molasses and aluminum/iron nitrate/sulfate salt binder systems evaluated in Matrix 3 are clearly superior to the baseline binder.

The modified molasses-salt binders represent a significant advance in binder technology in increasing the strength and abrasion resistance of briquettes. The potential for odor control needs further investigation. Additional benefits that can be obtained from these binder systems are 1) reduction in slag owing to elimination of inerts such as portland cement or hydrated lime, 2) reduction in furnace fuel requirements owing to lower heat burden for melting inert binder components, 3) simplification of the briquetting process, and 4) reduction of material handling. The cost of the additives has not been evaluated, but utilizing a small unit to convert steel waste to iron nitrate or sulfate might be considered. 


\section{BINDER MODIFICATION AND DEVELOPMENT FOR BRIQUETTING STEEL MILL RESIDUES}

\section{INTRODUCTION}

Blast furnace operations for steel production generate a diverse array of residues. The metallic residues include blast furnace dust, mill scale, blast oxygen furnace (BOF) precipitator dust, BOF metallic fines (metallic recovery from slag), and kish metallics (desulfurization waste materials). Cost recovery, energy efficiency, and environmental regulations are current driving factors for companies in developed countries to deal with steel mill residues acceptably.

The diverse steel mill residues need to be agglomerated before being recycled to the blast furnace. Disc pelletizers, pelletizer or extrusion die machines, and briquetting roll presses have been used. Using a double-roll briquetting press with and without binder to agglomerate the steel mill residues is currently an economically and environmentally sound practice in developed countries. In the absence of a binder, very high temperatures are used (e.g., $1470^{\circ}-1650^{\circ} \mathrm{F}$ ). Several papers attest to the substantial interest in agglomeration technology; particularly briquetting with binders via roll presses (Aumônier, 1995) and extrusion with binders (Steele, 1993) for recycling steel residues.

Commonly used binders for briquetting steel mill residues include molasses-hydrated lime (portlandite $\left[\mathrm{Ca}(\mathrm{OH})_{2}\right]$ ), lignosulfonate- $\mathrm{Ca}(\mathrm{OH})_{2}$, bentonite-cement, sodium silicate-cement, and cement-molasses, to name a few. Good green strength is required from the selected binder for the briquettes to survive initial handling and transport. In addition, the binder needs to provide subsequent high-temperature strength in order for the briquettes to withstand the elevated temperatures in the upper section of the blast furnace. The binder selected must be cost-effective, be applied at relatively low concentrations, exhibit acceptable blending characteristics, have benign qualities during handling and after application, and be in ready supply.

Several new binders or binder mixtures for use with iron/steel mill residues have appeared in the patent literature over the last 25 years. These include polyvinyl pyrrolidine, phenolaldehyde resin, starch plus polyvinyl alcohol (or with an acrylic or a gum), urethane (or epoxy resin), metal phosphate, and silica/clay. A major disincentive in using most of these binders is the cost of application or, in the case of the organic binders, their failure at high temperatures. For aggregating steel mill residues, Lambert (1995) has delineated the key problems of some past and currently used binders as well as the criteria for briquette strength relating to steel mill operations.

Fly ash and other waste products from combustion of fossil fuel are a potential resource for binder materials, owing to their content of aluminum and silicon and known pozzolanic activity: They interact strongly with cement and can replace a portion of cement, and they can provide a basis for their own cementious reactions. Methods for accelerating these reactions require further study. 
The search for the optimum binder for briquetting steel mill residues continues, motivated by cost and environmental pollution factors. Obnoxious odors ("wet campfire" smell) result from the use of effective molasses-ordinary portland cement (OPC) binders in the current practice. Increasing competition, more stringent regulations, and the drive for improved financial return on all aspects of operating a steel mill have focused attention on the need for an improved means of agglomerating waste by-products. Briquetting waste materials is an effective and efficient means of producing lump products from fine solid feedstocks which otherwise could contaminate the environment.

\section{BACKGROUND}

Heckett MultiServ has expressed a keen interest in the development and application of a modified or new binder in place of its existing binder for briquetting BOF and allied residues into pillow-shaped briquettes with dimensions of $3 \times 2.5 \times 1.25 \mathrm{in}$. The existing binder consists of molasses $(8 \mathrm{wt} \%)$-portland cement $(8 \mathrm{wt} \%)$ or molasses $(4 \mathrm{wt} \%)$-whey $(4 \mathrm{wt} \%)$-portland cement $(8 \mathrm{wt} \%)$. The major problems of these two binder mixtures are the dustiness of the briquettes, the insufficient strength of the briquettes at high temperatures (e.g., the molasseswhey-cement-based briquettes break up at about $570^{\circ}-750^{\circ} \mathrm{F}$ ), and the noxious odor emanating from the cooling towers following the addition of the briquettes to the blast furnace. It is believed that this odor is associated with the molasses component of the binder. The lack of binder strength is due to the weakness of the bond between the inorganic and organic components at temperatures above about $570^{\circ} \mathrm{F}$.

Heckett MultiServ in its many plants worldwide currently handles hundreds of thousands of tons of blast furnace residues. The economic potential for modifying or developing a suitable binder is critical, as are the environmental implications. The goal is to produce an acceptable binder with a cost of US\$12-\$15 per metric ton of briquetted product, i.e., no more than the cost of adding molasses, whey, and cement. The briquetted steel mill residue must have a suitable green strength and a high-temperature strength, say, at $700^{\circ}-800^{\circ} \mathrm{F}$, of about $50 \%$ of its cured ambient strength. No odor should result from use of the binder after transfer of the briquettes to the blast furnace. An understanding of the binder mechanism is also required for improving the binder and the conditions of application.

\section{OBJECTIVES}

The objectives were to investigate the following:

- Alternative components to molasses and or whey blended with portland cement as a binder for a mixture of steel mill residues. The modified binder is to yield briquettes of an acceptable green strength to withstand a 2 -ft drop, durability to moisture, adequate strength at high temperatures $\left(700^{\circ}-800^{\circ} \mathrm{F}\right)$ (i.e., $50 \%$ of the cured strength at ambient temperatures). In addition, the modified binder must not generate any noxious odors as 
a result of briquette use. The cost of the binder components should not exceed US\$15 per metric ton of briquetted product.

- A new noncement binder meeting the above criteria.

- The mechanism of binder action.

\section{ACCOMPLISHMENTS}

\section{Method Development}

\section{Hand Press - Standard Molasses-OPC Binder}

Tests were undertaken to develop a "standard" pellet based on the supplied blended steel mill residue and molasses-cement binder. Pellets were made by blending steel mill residues, $1.6 \mathrm{~g}$ of sugarcane molasses, and $1.6 \mathrm{~g}$ of OPC in a Simplimet 11 (Buehler Ltd.) mixer and pressing the mixture at about $7000 \mathrm{psi}$ to generate pellets $1.25 \mathrm{in}$. in diameter and about 1 in. long. The pellets were tested for green as well as cured strength by dropping them in air from a height of 42 in. onto a steel plate and by determining compressive strengths.

Seven conditions of mixing were tested, from room temperature to $140^{\circ} \mathrm{F}$. Various pressing conditions were applied to the mixture, again from room temperature to $140^{\circ} \mathrm{F}$, and pressing immediately, after 1 minute, or after 3 minutes. Conditions and test results are presented in Table 1.

Satisfactory pellets were produced at all temperatures using the pelleting press, but the heated mixture and mold gave somewhat stronger pellets. Generally, the drop tests resulted in little damage or cracking to the standard binder pellets.

\section{Briquetting - Komarek Press}

A series of three briquetting matrices was performed to allow evaluation of the most promising binders identified during bench-scale pelleting tests. A total of 35 briquetting tests was performed, with the conditions as specified in the tables in the Briquetting section. Binder concentrations are presented in the tables on a steel mill waste basis.

Some preliminary tests were performed using the polyvinyl alcohol (PVA)-OPC binder. This binder gave briquettes with acceptable drop test results, and compressive strengths were comparable to those obtained using the molasses-OPC binder. However, the briquettes were not fully evaluated with tumble tests, since the PVA binder gave poor results in the pyrolysis odor test. 
TABLE 1

Fabrication and Strength-Testing Conditions for Steel Mill Residue Pellets

\begin{tabular}{|c|c|c|c|c|}
\hline \multirow[b]{2}{*}{ Mixing Conditions } & \multirow[b]{2}{*}{$\begin{array}{l}\text { Pressing } \\
\text { Conditions }\end{array}$} & \multirow[b]{2}{*}{$\begin{array}{l}\text { Drop } \\
\text { Test }\end{array}$} & \multicolumn{2}{|c|}{ Compressive Strength (psi) } \\
\hline & & & Green & Cured \\
\hline Residue and & & & 32 & 242 \\
\hline Molasses at Room & & & 29 & 248 \\
\hline \multirow[t]{2}{*}{ Temperature } & Mold at $75^{\circ} \mathrm{F}$ & All pellets passed. & 32 & 242 \\
\hline & & & Avg. $=31$ & $A v g:=244$ \\
\hline Residue and $O P C$ at & & & 38 & 286 \\
\hline $75^{\circ} \mathrm{F}$ - Hot Molasses & & & 39 & 273 \\
\hline$\left(100^{\circ} \mathrm{F}\right)$ Added and & & & 38 & 273 \\
\hline Mixed Thoroughly & Mold at $100^{\circ} \mathrm{F}$ & All pellets passed. & Avg: $=38$ & Avg, $=277$ \\
\hline
\end{tabular}

Briquetting Tests 1 to 15 were performed between October 3 and 7, 1997; Tests 16 to 24 were performed on December 17, 1997; and Tests 25 to 35 were performed between May 13 and 22, 1998. Tests 1 to 15 and 25 to 35 were performed using -16-mesh steel mill waste, and Tests 16 to 24 used -1/a-in. steel mill waste. Briquettes were produced using a Komarek Model B100R cantilever roll press equipped with 5 -in.-diameter by 2 -in.-wide rolls. The briquetter rolls contain 18 pockets and produce briquettes with nominal dimensions of $1 / 1 / 4 \times 7 / 6 \times 1 / 2$ inl. The briquetter is equipped with a steel chute to collect briquettes directly at the roll discharge.

Briefly, for each test, between 3000 and $4000 \mathrm{~g}$ of steel mill waste was used. The procedures for binder addition differed between matrices. For Matrices 1 (Tests 1 to 15) and 2 (Tests 16 to 24), the dry binder components (Corrette fly ash, hydrated lime, sodium bentonite, Heckett Multiserv fly ash, and portland cement) were added first to the dry steel mill waste, with water and American Crystal Sugar beet molasses (preheated to $135^{\circ} \mathrm{F}$ ) than added. For Matrix 3 (Tests 25 to 35 ), the dry binder components (ferric nitrate, aluminum nitrate, ferrous sulfate, and ferric sulfate) were added to the Heckett Multiserv molasses. The molasses was preheated to $100^{\circ} \mathrm{F}$ prior to addition to the steel mill waste. Mixing of the steel mill waste and binder components was achieved using a hand-held kitchen-type blender. All wet binder components were incrementally added to facilitate distribution on the steel mill waste.

Tests 1 to 3 functioned as shakedown tests to determine suitable operating conditions with the B100R briquetter. For subsequent tests, a roll speed of $3 \mathrm{rpm}$ ( $25 \%$ of maximum speed) and a roll separation force of $90 \mathrm{kN} \mathrm{(} 90 \%$ of maximum) were used. To attain uniformity of briquetting conditions from test to test, an attempt was made to achieve a nominal foll torque of $950700 \mathrm{ft}-$ $1 \mathrm{~b}_{\mathrm{j}}$. This was accomplished by adjusting the screw feed rate. During shakedown, it was determined that the roll timing was off slightly, but this was considered to be insignificant for the purpose of comparative briquette evaluations. 
For each test, eight or nine briquettes were collected from the discharge chute of the briquetter and were then used for green strength determinations. The remaining briquettes were collected in a 5-gal plastic pail after a vertical drop of about $16 \mathrm{in}$. The collected briquettes were screened with $1 / 4$-in. sieve to remove flashing and then spread in a single layer on a flat surface to dry at the prevailing conditions of the laboratory.

\section{Briquette Evaluation}

Briquette evaluations included drop-shatter, compressive strength, and tumble (abrasion resistance) testing. For drop-shatter testing, five or six briquettes were sequentially dropped through a 34 -in.-long, 1.5 -in.-ID steel pipe, oriented with the bottom opening 8 in. from the concrete floor. The briquettes were given a pass or fail ranking. A pass rating was given to briquettes that largely remained intact with only minor chipping or deformation. A fail rating was given to briquettes that broke into several substantially smaller fragments or disintegrated.

For compressive strength testing, a briquette was stressed between a stationary block and a moveable platen on a spring-type load tester. A dial indicator measured the deflection of the calibrated spring on the load tester. The briquette was stressed until deflection of the spring stopped. This usually indicated the point at which the briquette fractured or catastrophically failed. The maximum deflection, as measured by the dial indicator, was converted to a force using a calibration curve for the spring. A normalized compressive strength was obtained by dividing the force value by the thickness of the briquette as measured by a dial caliper. The average compressive strength value for the three briquettes is reported.

Tumble testing was performed in a 7.8-in.-long $\times 7.8$-in.-diameter stainless steel vessel with a wall thickness of $1 / 4$ in. The tumbling vessel was outfitted with three 1 -in.-wide lifters to increase tumbling intensity. For this procedure, six briquettes were weighed and then charged to the tumbling vessel. The vessel was turned on rollers at $40 \mathrm{rpm}$ for 20 minutes. The proper tumbling conditions were determined from shakedown tests performed using briquettes from Test 14 of the first matrix. The contents of the tumbling vessel was screened with a $1 / 4-$ in. sieve and the material retained on the screen weighed to determine the percent recovery.

Drop-shatter and compressive strength testing were performed on green briquettes, typically between 1 and 3 minutes after the briquette was produced. Compressive strength and tumble testing were performed on briquettes that had been air-dried for 2 and 7 days.

\section{Sand Rammer}

Testing with the sand rammer using the molasses-OPC binder for the steel waste mixture gave sporadic results. Nearly all the large pellets exhibited cracks or deformed shapes. It was difficult to judge exactly how much water to add, and limited testing with other binders gave similarly poor results. Although Heckett Multiserv has utilized this test method, we found it difficult to evaluate the results of our tests. The pellets pressed in the hand press and briquettes were superior in quality, and evaluation of the results could be done by compression testing, which gives a value for the strength. 


\section{Odor Tests}

Pyrolysis odor tests were conducted with the molasses binder to determine the basis for potential environmental problems resulting from use of various binders. A 7-g sample of a cured pellet prepared with molasses-OPC was heated in a tube furnace from ambient temperature to $600^{\circ} \mathrm{C}$. At about $300^{\circ} \mathrm{C}$, the wet campfire odor that is characteristic of the molasses briquette pyrolysis was considerable. The evolving gases were bubbled through water and a water sample stored in a freezer. The water sample continued to evolve the odor for some time, but after a day the pellet sample emitted a strong freshly poured cement odor.

\section{Binder Studies}

\section{PVA Binders}

After several unsuccessful attempts to dissolve PVA in water, the more soluble hydrolyzed PVA (Elmer's glue) was used for the macromolecular binder. The binder was prepared by diluting $4 \mathrm{~g}$ of the glue (moisture content $=59 \mathrm{wt} \%$ ) with $8 \mathrm{~g}$ of water.

The steel residue ( $20 \mathrm{~g})$, diluted glue (1.2 or $1.6 \mathrm{~g})$, and OPC $(1.2$ or $1.6 \mathrm{~g})$ and, on occasion, $\mathrm{Ca}(\mathrm{OH})_{2}$, were thoroughly mixed and the mixture pressed in the Simplimet hand press. As previously, the pressure was about $7000 \mathrm{psi}$. The 1.25-in.-diameter pellets were tested for green strength by dropping them down a tube in air from a height of 42 in. onto a steel plate. The results are given in Table 2.

\section{TABLE 2}

PVA Binders

\begin{tabular}{lcccccc}
\hline & & & & & \multicolumn{2}{c}{$\begin{array}{c}\text { Compressive Strength } \\
\text { (psi) }\end{array}$} \\
\cline { 5 - 7 } $\begin{array}{l}\mathrm{PVA} \\
(\mathrm{wt} \%)\end{array}$ & $\begin{array}{c}\mathrm{OPC} \\
(\mathrm{wt} \%)\end{array}$ & $\begin{array}{c}\mathrm{Ca}(\mathrm{OH})_{2} \\
(\mathrm{wt} \%)\end{array}$ & $\begin{array}{c}\mathrm{H}_{2} \mathrm{O} \\
(\mathrm{wt} \%)\end{array}$ & $\begin{array}{c}\text { Drop } \\
\text { Test }\end{array}$ & Green & Cured \\
\hline 1 & 4 & 4 & 6.4 & Passed & 45 & 172 \\
1 & 8 & 0 & 6.4 & Passed & 51 & 204 \\
1 & 4 & 0 & 6.4 & Passed & 41 & 159 \\
1 & 0 & 4 & 6.4 & Passed & 44 & 178 \\
1 & 0 & 8 & 6.4 & Passed & 51 & 204 \\
1 & 4 & $4(\mathrm{CaO})$ & 6.4 & Passed & 48 & 210 \\
\hline
\end{tabular}


Pellets prepared with $4 \%$ and $8 \% \mathrm{Ca}(\mathrm{OH})_{2}$ and with $4 \%$ and $8 \%$ OPC were nearly comparable in strength. Use of $\mathrm{CaO}$ gave a high-strength pellet.

Comparison of the data in Tables 1 and 2 shows that the green strength of the pellets produced with Elmer's glue and cement was markedly greater than the green strength of the standard molasses-OPC pellets. The Elmer's glue-produced pellets also exhibited a very good appearance.

The effect of water content on the strength of the pellets was investigated by using a different dilution of the PVA solution. The results are given in Table 3 . The $2 \%$ water content was too low to adequately wet the particles, and not much strength developed during curing. Maximum strength was obtained at the $4 \%$ water content.

Since the $1 \%$ PVA binder concentration used in the previous tests would likely result in costs exceeding $\$ 20 /$ ton of product, lower concentrations of the binder were investigated. All of the pellets prepared with $0.75 \%$ PVA passed the drop test and developed acceptable cured strengths. When the concentration was reduced to $0.5 \%$ PVA, the pellets exhibited cracks in the drop test (Table 4). Green strength was not evaluated for this concentration.

A pyrolysis odor test was conducted to determine whether an environmental problem is likely to occur as it does with the molasses binder. A 7-g sample of a cured pellet prepared with PVA and $\mathrm{Ca}(\mathrm{OH})_{2}$ was heated in a tube furnace from ambient temperature to $500^{\circ} \mathrm{C}$. At about $300^{\circ} \mathrm{C}$, the wet campfire odor that is characteristic of the molasses briquette pyrolysis was considerable. The evolving gases were bubbled through water and a water sample stored in a freezer. Water continued to evolve the odor for some time, but after a day, no odor was observed. The frozen sample was thawed, and the odor had changed to a slight aldehyde odor and later to a strong freshly poured cement odor.

TABLE 3

Effect of Water Content on PVA Pellets

\begin{tabular}{lcccccc}
\hline & & & & \multicolumn{2}{c}{$\begin{array}{c}\text { Compressive Strength } \\
\text { (psi) }\end{array}$} \\
\cline { 5 - 7 } $\begin{array}{l}\text { PVA } \\
(\mathrm{wt} \%)\end{array}$ & $\begin{array}{c}\mathrm{OPC} \\
(\mathrm{wt} \%)\end{array}$ & $\begin{array}{c}\mathrm{Ca}(\mathrm{OH})_{2} \\
(\mathrm{wt} \%)\end{array}$ & $\begin{array}{c}\mathrm{H}_{2} \mathrm{O} \\
(\mathrm{wt} \%)\end{array}$ & $\begin{array}{c}\text { Drop } \\
\text { Test }\end{array}$ & Green & Cured \\
\hline 1 & 8 & 0 & 6.4 & Passed & 51 & 204 \\
1 & 0 & 8 & 6.4 & Passed & 51 & 204 \\
1 & 8 & 0 & 4 & Passed & 54 & 217 \\
1 & 0 & 8 & 4 & Passed & 67 & 229 \\
1 & 8 & 0 & 2 & Failed & 50 & 89 \\
1 & 0 & 8 & 2 & Failed & 51 & 95 \\
\hline
\end{tabular}


TABLE 4

Effect of Binder Concentration

\begin{tabular}{|c|c|c|c|c|c|c|}
\hline \multirow[b]{2}{*}{$\begin{array}{l}\text { PVA } \\
\text { (wt\%) }\end{array}$} & \multirow[b]{2}{*}{$\begin{array}{c}\text { OPC } \\
(w t \%)\end{array}$} & \multirow[b]{2}{*}{$\begin{array}{c}\mathrm{Ca}(\mathrm{OH})_{2} \\
(\mathrm{wt} \%)\end{array}$} & \multirow[b]{2}{*}{$\begin{array}{c}\mathrm{H}_{2} \mathrm{O} \\
(\mathrm{wt} \%)\end{array}$} & \multirow[b]{2}{*}{$\begin{array}{c}\text { Drop } \\
\text { Test }\end{array}$} & \multicolumn{2}{|c|}{$\begin{array}{l}\text { Compressive Strength } \\
\text { (psi) }\end{array}$} \\
\hline & & & & & Green & Cured \\
\hline 0.75 & 4 & 4 & 5 & $\mathrm{P}$ & 43 & 165 \\
\hline 0.75 & 8 & 0 & 5 & $\mathrm{P}$ & 48 & 172 \\
\hline 0.75 & 0 & 8 & 4 & $\mathrm{P}$ & 57 & 185 \\
\hline 0.75 & 0 & 4 & 4 & $P$ & 54 & 178 \\
\hline 0.5 & 0 & 8 & 4 & Cracked & $\mathrm{NA}^{1}$ & NA \\
\hline
\end{tabular}

${ }^{1}$ Not applicable

\section{Other Polymer Binders}

Other macromolecular binders were investigated (Table 5). These include polyvinylpyrrolidoneco-polyvinyl acetate (PVPcoPVA), polyethylene oxide, polyacrylamide, and a water-soluble low-sulfur lignin preparation, all at $1 \mathrm{wt} \%$ concentrations in the pellets. The PVPcoPVA binder with $\mathrm{Ca}(\mathrm{OH})_{2}$ and with $\mathrm{OPC}$ gave pellets that passed the drop test, but did not develop significant cured strength. A second series of tests did not pass the drop test. Other binders (polyethylene oxide [PEO], polyacrylamide, and lignin) with $8 \% \mathrm{Ca}(\mathrm{OH})_{2}$ failed the drop test and were not further investigated with OPC.

TABLE 5

Other Macromolecular Binders

Compressive

Strength (psi)

\begin{tabular}{lcccccccc}
$\begin{array}{l}\text { Organic Binder } \\
\text { (wt\%) }\end{array}$ & $\begin{array}{c}\text { Cheto Clay } \\
\text { (wt\%) }\end{array}$ & $\begin{array}{c}\mathrm{OPC} \\
(\mathrm{wt} \%)\end{array}$ & $\begin{array}{c}\mathrm{Ca}(\mathrm{OH})_{2} \\
(\mathrm{wt} \%)\end{array}$ & $\begin{array}{c}\mathrm{H}_{2} \mathrm{O} \\
(\mathrm{wt} \%)\end{array}$ & $\begin{array}{c}\text { Drop } \\
\text { Test }\end{array}$ & Green & Cured \\
\hline PVPcoPVA & 1 & 0 & 8 & 0 & 5 & $\mathrm{P}$ & 25 & 89 \\
PVPcoPVA & 1 & 0 & 0 & 8 & 5 & $\mathrm{P}$ & 27 & 95 \\
PVPcoPVA & 1 & 0 & 0 & 8 & 5 & $\mathrm{~F}$ & NA & NA \\
PVPcoPVA & 1 & 0 & 8 & 0 & 5 & $\mathrm{~F}$ & NA & NA \\
PEO & 1 & 0 & 0 & 8 & 5 & F & NA & NA \\
Polyacrylamide & 1 & 0 & 0 & 8 & 5 & F & NA & NA \\
Lignin & 1 & 0 & 0 & 8 & 5 & F & NA & NA \\
\hline
\end{tabular}




\section{Clay Binders}

Clay minerals can be divided into two general categories, the swelling clays and the nonswelling clays. Swelling clays are often referred to as smectites, which is a general term for all the swelling clays. Of the smectites, montmorillonite is probably the most common form. Nonswelling clays do not have a general group name but include kaolinite, illite, and chlorite as commonly occurring forms. The swelling-versus-nonswelling mechanism involves water, which in the smectites is able to move in and out of the sheetlike layers without destroying the clay mineral structure. Nonswelling clays collapse upon dehydration, which is not a reversible reaction with the exception of a few species that hold water in columns rather than between their sheetlike layers.

Three properties exhibited by smectite clays allow these materials to be considered as a potential binding medium. The first has to do with the "balling," or ability of smectites to stick to each other, which is evident to anyone who has ever stepped in mud. The ability of selfadherence has to do partly with the size and shape of the particles, which are extremely small $(<2 \mu \mathrm{m})$, platelike crystals. The platelike crystals end up in somewhat random orientation and form a meshlike grid. The second property is related to a slight electrical imbalance often exhibited on the surface of the crystals. This helps particles to adhere to each other as well as to form weak bonds to the materials to be bonded. The third property has to do with the chemistry of the clay minerals, which contain mostly $\mathrm{SiO}_{2}$ and $\mathrm{Al}_{2} \mathrm{O}_{3}$. These components become available to react with other compounds at or about a pH of 9. When $\mathrm{Ca}(\mathrm{OH})_{2}$ is added to swelling clays, the $\mathrm{SiO}_{2}$ and $\mathrm{Al}_{2} \mathrm{O}_{3}$ react with the $\mathrm{Ca}(\mathrm{OH})_{2}$ and form calcium aluminum silicate hydrates, which are often the same or very similar to the cementitious phases found in portland cement concrete and are known to have good long-term binding properties.

\section{Cheto Clay Binders}

Cheto (montmorillonite) clay was tested as a binder for steel waste pellets. The cheto clay is a very sticky clay, and it was hoped that it would provide some green strength to the briquettes. However, this work established that the clay by itself or with sodium aluminate $\left(\mathrm{NaAlO}_{2}\right)$ was not an effective binder (Table 6). With addition of $\mathrm{Ca}(\mathrm{OH})_{2}$, the pellets passed the drop test and developed some strength on curing, but were far inferior to those formed with the molasses binder.

\section{Mixed Clay-PVA Binders}

When the PVA binder was utilized (1\%) with a montmorillonite (cheto) clay ( $8 \%$ ), the pellet passed the drop test (Table 7) and developed considerable cured strength (178 psi). This binder-clay combination represents an alternative to the patented binder mixtures of PVA with $\mathrm{Ca}(\mathrm{OH})_{2}$ and with $\mathrm{OPC}$. The mechanism of bond formation may involve reaction of the PVA alcohol groups with ions and layers of the clay structure similar to those reactions occurring with the calcium in $\mathrm{OPC}$ or $\mathrm{Ca}(\mathrm{OH})_{2}$. 
TABLE 6

Results with Cheto Clay Binders

\begin{tabular}{lcccccccc}
\hline & & & & & & \multicolumn{2}{c}{$\begin{array}{c}\text { Compressive } \\
\text { Strength (psi) }\end{array}$} \\
\cline { 6 - 9 } $\begin{array}{l}\text { Cheto Clay } \\
(\mathrm{wt} \%)\end{array}$ & $\begin{array}{c}\mathrm{OPC} \\
(\mathrm{wt} \%)\end{array}$ & $\begin{array}{c}\mathrm{NaAlO}_{2} \\
(\mathrm{wt} \%)\end{array}$ & $\begin{array}{c}\mathrm{Ca}(\mathrm{OH})_{2} \\
(\mathrm{wt} \%)\end{array}$ & $\begin{array}{c}\mathrm{H}_{2} \mathrm{O} \\
(\mathrm{wt} \%)\end{array}$ & $\begin{array}{c}\text { Drop } \\
\text { Test }\end{array}$ & Green & Cured \\
\hline 8 & 0 & 0 & 0 & 4 & Failed & - & - \\
6.3 & 0 & 0 & 6.30 & 8 & Passed & 13 & 89 \\
6.1 & 0 & 0 & 6.1 & 11 & Passed & 32 & 105 \\
6.2 & 0 & 0 & 3.1 & 12 & Passed & - & 108 \\
5.4 & 0 & 1.8 & 0 & 3.5 & Failed (d) & - & - \\
3.5 & 3.5 & 1.8 & 0 & 3.5 & Failed (t) & - & - \\
3.5 & 0 & 1.8 & 3.5 & 3.5 & Failed (d) & - & - \\
\hline $\mathrm{d}=$ duplicate; $\mathrm{t}=$ triplicate. & & & & & & &
\end{tabular}

TABLE 7

Clay-PVA Binders

\begin{tabular}{lrcccccccc}
\hline & & & & & & \multicolumn{3}{c}{$\begin{array}{c}\text { Compressive } \\
\text { Strength (psi) }\end{array}$} \\
\cline { 7 - 10 } $\begin{array}{l}\text { Organic Binder } \\
(\mathrm{wt} \%)\end{array}$ & $\begin{array}{c}\text { Cheto Clay } \\
(\mathrm{wt} \%)\end{array}$ & $\begin{array}{c}\mathrm{OPC} \\
(\mathrm{wt} \%)\end{array}$ & $\begin{array}{c}\mathrm{Ca}(\mathrm{OH})_{2} \\
(\mathrm{wt} \%)\end{array}$ & $\begin{array}{c}\mathrm{H}_{2} \mathrm{O} \\
(\mathrm{wt} \%)\end{array}$ & $\begin{array}{c}\text { Drop } \\
\text { Test }\end{array}$ & Green & Cured \\
\hline PVA & 0.75 & 8 & 0 & 0 & 4 & $\mathrm{P}$ & 89 & 178 \\
PVA & 0 & 8 & 0 & 0 & 4 & F & - & - \\
\hline
\end{tabular}

Sodium Bentonite Binders

Another clay (bentonite) was tested in the sodium form as a binder for steel waste pellets. The sodium bentonite was ground to -60 -mesh size and pelleted and tested as described above. Results are given in Table 8. Some success was achieved in the drop tests, but none of the pellets exhibited cured strengths comparable to that of pellets made with the molasses binders.

\section{Fly Ash Binders}

\section{Fly Ash-Lime Binders}

A fly ash sample (HM ash) was obtained from Heckett Multiserv that would be representative of locally obtained fly ash. The analysis showed $21.3 \% \mathrm{Al}_{2} \mathrm{O}_{3}, 6.08 \% \mathrm{CaO}$, and $0.70 \% \mathrm{Na}_{2} \mathrm{O}$. Ash was mixed with steel waste and $\mathrm{Ca}(\mathrm{OH})_{2}$ and minimal water, hand pelletized, 
TABLE 8

Bentonite-Lime Pellets

\begin{tabular}{|c|c|c|c|c|}
\hline $\begin{array}{l}\text { Additive } \\
\text { (g) }\end{array}$ & $\begin{array}{l}\text { Binder } \\
(\mathrm{g})\end{array}$ & $\begin{array}{l}\text { Water } \\
(\mathrm{g})\end{array}$ & $\begin{array}{l}\text { Drop } \\
\text { Test }\end{array}$ & $\begin{array}{c}\text { Cured } \\
\text { Compressive Strength (psi) }\end{array}$ \\
\hline $\begin{array}{l}\text { Lime } \\
(0.8)\end{array}$ & $\begin{array}{c}\text { Sod. Bentonite } \\
\text { (1.6) }\end{array}$ & 3 & Passed & - \\
\hline $\begin{array}{l}\text { Lime } \\
(0.8)\end{array}$ & $\begin{array}{l}\text { Sod. Bentonite } \\
\text { (1.6) }\end{array}$ & 3 & Passed & 89 \\
\hline $\begin{array}{l}\text { Lime } \\
(0.8)\end{array}$ & $\begin{array}{c}\text { Sod. Bentonite } \\
(0.8)\end{array}$ & 3 & Passed & - \\
\hline $\begin{array}{l}\text { Lime } \\
(0.8)\end{array}$ & $\begin{array}{l}\text { Sod. Bentonite } \\
\quad(0.8)\end{array}$ & 3 & Passed & 115 \\
\hline $\begin{array}{l}\text { Lime } \\
(0.4)\end{array}$ & $\begin{array}{l}\text { Sod. Bentonite } \\
(0.8)\end{array}$ & 3 & Passed & - \\
\hline $\begin{array}{l}\text { Lime } \\
(0.4)\end{array}$ & $\begin{array}{l}\text { Sod. Bentonite } \\
\quad(0.8)\end{array}$ & 3 & Passed & 76 \\
\hline $\begin{array}{l}\text { Lime } \\
(0.4)\end{array}$ & $\begin{array}{c}\text { Sod. Bentonite } \\
(0.8)\end{array}$ & 2 & Passed & - \\
\hline $\begin{array}{l}\text { Lime } \\
(0.4)\end{array}$ & $\begin{array}{l}\text { Sod. Bentonite } \\
(0.8)\end{array}$ & 2 & Passed & 89 \\
\hline $\begin{array}{l}\text { OPC } \\
(0.8)\end{array}$ & $\begin{array}{c}\text { Sod. Bentonite } \\
(0.4)\end{array}$ & 2 & Passed & - \\
\hline $\begin{array}{l}\mathrm{OPC} \\
(0.8)\end{array}$ & $\begin{array}{c}\text { Sod. Bentonite } \\
(0.4)\end{array}$ & 2 & Passed & 96 \\
\hline
\end{tabular}

and tested as described above (Table 9). The pellets from the unprocessed ash failed the drop test.

U.S. Patent 5,565,028 describes the addition of alkali to fly ash to improve setting times of cementitious ash. Sodium hydroxide $(\mathrm{NaOH})$ was added to the $\mathrm{HM}$ ash-steel waste mixture to help solubilize silicate for reaction with $\mathrm{Ca}(\mathrm{OH})_{2}$. These pellets also failed the drop test. Some strength did develop on curing these pellets.

Pretreatment of the $\mathrm{HM}$ ash with $\mathrm{NaOH}$ was attempted to solubilize some of the aluminate and silicate, so that on mixture with the $\mathrm{Ca}(\mathrm{OH})_{2}$, a cementitious reaction could take place more quickly. Thus, a binder was prepared by mixing $20 \mathrm{~g}$ of $\mathrm{HM}$ ash with $14 \mathrm{~g}$ of $\mathrm{NaOH}$ in $20 \mathrm{~g}$ of water and heating to $95^{\circ} \mathrm{C}$ overnight (Binder 1). The binder paste was then mixed with steel 
TABLE 9

Fly Ash-Lime Binders

\begin{tabular}{|c|c|c|c|c|}
\hline $\begin{array}{l}\text { Additive } \\
\text { (g) }\end{array}$ & $\begin{array}{l}\text { Binder } \\
(\mathrm{g})\end{array}$ & $\begin{array}{l}\text { Water } \\
\text { (g) }\end{array}$ & $\begin{array}{l}\text { Drop } \\
\text { Test }\end{array}$ & $\begin{array}{c}\text { Cured } \\
\text { Compressive Strength (psi) }\end{array}$ \\
\hline None & $\begin{array}{l}\text { HM Ash } \\
\text { (1.6) }\end{array}$ & 3 & $\begin{array}{c}\text { Failed } \\
\text { (duplicate) }\end{array}$ & - \\
\hline $\begin{array}{l}\text { Lime } \\
(0.8)\end{array}$ & $\begin{array}{l}\text { HM Ash } \\
\text { (1.6) }\end{array}$ & 3 & Failed $^{1}$ & - \\
\hline $\begin{array}{l}\text { Lime } \\
(0.8)\end{array}$ & $\begin{array}{l}\text { HM Ash } \\
(1.6)\end{array}$ & 3 & Failed $^{1}$ & 82 \\
\hline $\begin{array}{l}\text { Lime } \\
(0.8)\end{array}$ & $\begin{array}{l}\text { HM Ash } \\
(1.6)\end{array}$ & $\begin{array}{c}10 \% \mathrm{NaOH} \\
3\end{array}$ & Failed $^{1}$ & - \\
\hline $\begin{array}{l}\text { Lime } \\
(0.8)\end{array}$ & $\begin{array}{l}\text { HM Ash } \\
(1.6)\end{array}$ & $\begin{array}{c}10 \% \mathrm{NaOH} \\
3\end{array}$ & Failed $^{1}$ & 89 \\
\hline $\begin{array}{l}\text { Lime } \\
(0.8)\end{array}$ & $\begin{array}{c}\text { Binder I } \\
(1.6)\end{array}$ & 3 & Failed $^{1}$ & - \\
\hline $\begin{array}{l}\text { Lime } \\
(0.8)\end{array}$ & $\begin{array}{l}\text { Binder I } \\
(1.6)\end{array}$ & 3 & Failed $^{1}$ & 89 \\
\hline $\begin{array}{l}\text { Lime } \\
(0.8)\end{array}$ & $\begin{array}{c}\text { Binder II } \\
(1.6)\end{array}$ & 3 & Passed & - \\
\hline $\begin{array}{l}\text { Lime } \\
(0.8)\end{array}$ & $\begin{array}{l}\text { Binder II } \\
(1.6)\end{array}$ & 3 & Failed $^{1}$ & - \\
\hline None & $\begin{array}{l}\text { Binder III } \\
(1.6)\end{array}$ & - & $\begin{array}{c}\text { Failed } \\
\text { (duplicate) }\end{array}$ & - \\
\hline $\begin{array}{l}\text { Water } \\
(0.3)\end{array}$ & $\begin{array}{l}\text { Binder III } \\
(1.6)\end{array}$ & 0.3 & $\begin{array}{c}\text { Failed } \\
\text { (duplicate) }\end{array}$ & - \\
\hline
\end{tabular}

waste and the mixture pressed into pellets and tested. However, the pellets again failed the drop test. Binder II was prepared by mixing $8 \mathrm{~g}$ of fly ash with $10 \mathrm{~g}$ of $20 \% \mathrm{NaOH}$ and heating at $100^{\circ} \mathrm{F}$ for 1 hour. Binder III was prepared by heating $14 \mathrm{~g}$ of ash with $2 \mathrm{~g}$ of $\mathrm{Ca}(\mathrm{OH})_{2}$ and $6.4 \mathrm{~g}$ of $20 \% \mathrm{NaOH}$ in a digestion bomb at $100^{\circ} \mathrm{C}$ for 1 hour. None of these binders gave pellets with acceptable green strengths. 


\section{Class C Fly Ash Binders}

A Class $\mathrm{C}$ fly ash (Corrette) was also ineffective by itself. An alkali-activated binder. (Binder AI) was prepared by mixing $20 \mathrm{~g}$ of class $\mathrm{C}$ ash with a solution of $14 \mathrm{~g} \mathrm{NaOH}$ in $20 \mathrm{~g}$ water. The paste was heated at $95^{\circ} \mathrm{C}$ overnight. The residue was heated at $450^{\circ} \mathrm{C}$ for 3 hours. The residue was ground to -60 mesh size and pelleted with steel waste as described above. Results are shown in Table 10 .

When mixed with water and $\mathrm{Ca}(\mathrm{OH})_{2}$, the calcined fly ash mixture (Binder AI) rapidly sets as a result of cementitious reactions. The results were compared with results for the same fly ash without calcining. The results from the two tests were similar. The pellets did not disintegrate on impact, but cracked in half. Considerable strength developed on curing the uncracked pellets.

TABLE 10

Results with Class C Fly Ash Binders

\begin{tabular}{lccccc}
\hline $\begin{array}{c}\text { Binder } \\
\text { AI } \\
(\mathrm{wt} \%)\end{array}$ & $\begin{array}{c}\text { Class C } \\
\text { Fly Ash } \\
(\mathrm{wt} \%)\end{array}$ & $\begin{array}{c}\mathrm{Ca}(\mathrm{OH})_{2} \\
(\mathrm{wt} \%)\end{array}$ & $\mathrm{H}_{2} \mathrm{O}(\mathrm{wt} \%)$ & $\begin{array}{c}\text { Drop } \\
\text { Test }\end{array}$ & $\begin{array}{c}\text { Cured Compressive } \\
\text { Strength (psi) }\end{array}$ \\
\hline 8 & 0 & 4 & 2 & Failed (d) & - \\
8 & 0 & 4 & 3 & Failed (d) & - \\
8 & 0 & 4 & 2 & - & 146 \\
6.5 & 0 & 3.3 & 8 & Cracked (d) & - \\
6.3 & 0 & 3.2 & 11 & Cracked (t) & 146 \\
0 & 6.3 & 6.3 & 8 & Cracked (d) & - \\
0 & 6.1 & 6.1 & 11 & Cracked (d) & - \\
0 & 6.2 & 3.1 & 12 & - & 153 \\
0 & 6.2 & 3.1 & $12(10 \% \mathrm{NaOH})$ & - & 159 \\
\hline $\mathrm{d}=$ duplicate; $\mathrm{t}$ = triplicate. & & & &
\end{tabular}

\section{Clay-Ash Composite Binders}

\section{Clay-Ash mixtures}

Sodium bentonite and cheto clay were ground to -60 -mesh size and used as a binder for steel waste. Corrette (Class C) ash was used as received. Pellets were prepared and tested as above. 
Two batches of a binder were prepared by mixing $24 \mathrm{~g}$ of Class $\mathrm{C}$ ash with a solution of 20 $\mathrm{g}$ of $1 \mathrm{~N} \mathrm{NaOH}$ in water. The slurry was thoroughly mixed to form a paste. Upon stirring, the control slurry batch (not mixed with steel waste) thickened and became solid after overnight standing, retaining $83 \%$ of the added water. Results are given in Table 11 . Strengths were not comparable with those for the molasses binders.

\section{TABLE 11}

Results from Ash-Clay Composite Binders

\begin{tabular}{|c|c|c|c|c|}
\hline $\begin{array}{l}\text { Clay } \\
\text { (g) }\end{array}$ & $\begin{array}{l}\text { Ash } \\
(\mathrm{g})\end{array}$ & $\begin{array}{l}\text { Water } \\
(\mathrm{g})\end{array}$ & $\begin{array}{l}\text { Drop } \\
\text { Test }\end{array}$ & $\begin{array}{l}\text { Cured Compressive } \\
\text { Strength (psi) }\end{array}$ \\
\hline $\begin{array}{l}\text { Sodium } \\
\text { Bentonite } \\
(0.4)+ \\
\text { Lime }(0.8)\end{array}$ & $\begin{array}{l}\text { Class } C \text { ash } \\
\quad(1.6)\end{array}$ & (3) & Passed & - \\
\hline $\begin{array}{l}\text { Sodium } \\
\text { Bentonite } \\
(0.4)+ \\
\text { Lime }(0.8)\end{array}$ & $\begin{array}{c}\text { Class } C \text { ash } \\
\quad(1.6)\end{array}$ & (3) & Passed & 146 \\
\hline $\begin{array}{l}\text { Sodium } \\
\text { Bentonite } \\
(0.4)+ \\
\text { Lime }(0.8)\end{array}$ & $\begin{array}{l}\text { Class } C \text { ash } \\
\text { (1.6) }\end{array}$ & (2) & Passed & - \\
\hline $\begin{array}{l}\text { Sodium } \\
\text { Bentonite } \\
(0.4)+ \\
\text { Lime }(0.8)\end{array}$ & $\begin{array}{l}\text { Class } \mathrm{C} \text { ash } \\
\quad(1.6)\end{array}$ & (2) & Passed & 153 \\
\hline $\begin{array}{l}\text { Cheto clay } \\
(0.4)+ \\
\text { Lime }(0.8)\end{array}$ & $\begin{array}{c}\text { Class } C \text { ash } \\
(1.6)\end{array}$ & (2) & Passed & 115 \\
\hline $\begin{array}{l}\text { Cheto clay } \\
(0.4)+ \\
\text { Lime }(0.8)\end{array}$ & $\begin{array}{c}\text { Class } C \text { ash } \\
\text { (1.6) }\end{array}$ & (2) & Passed & - \\
\hline
\end{tabular}


The second batch was mixed after certain time intervals with steel waste to determine the effect of pretreatment time on the strength. As-received steel waste was sized to obtain particles less than $1 / 8$ in. in size. To $20 \mathrm{~g}$ of steel waste fines, $0.8 \mathrm{~g}$ of Ca(OH $)_{2}$ and $0.6 \mathrm{~g}$ of sodium bentonite were added and thoroughly mixed. To the mixture, $4.4 \mathrm{~g}$ of the binder paste was added and thoroughly mixed after 1-hour time intervals (Table 12). Pellet strength decreased with pretreatment time in this experiment. This implies that the cementitious reactions may occur fairly rapidly when $\mathrm{NaOH}$ is added to the ash to solubilize silicate.

\section{TABLE 12}

Effect of Time Delay on Pellet Strength

\begin{tabular}{|c|c|c|c|c|c|}
\hline $\begin{array}{l}\text { Time } \\
\text { (hr) }\end{array}$ & $\begin{array}{c}\text { Steel Waste } \\
(\mathrm{g})\end{array}$ & $\begin{array}{c}\mathrm{Ca}(\mathrm{OH})_{2} \\
(\mathrm{~g})\end{array}$ & $\begin{array}{c}\text { Sodium Bentonite } \\
\text { (g) }\end{array}$ & $\begin{array}{c}\text { Binder }^{1} \\
(\mathrm{~g})\end{array}$ & $\begin{array}{l}\text { Compressive } \\
\text { Strength (psi) }\end{array}$ \\
\hline 1 & 20 & 0.8 & 0.6 & 4.4 & 227 \\
\hline 2 & 20 & 0.8 & 0.6 & 4.4 & 204 \\
\hline 3 & 20 & 0.8 & 0.6 & 4.4 & 191 \\
\hline 4 & 20 & 0.8 & 0.6 & 4.4 & 159 \\
\hline
\end{tabular}

Earlier briquetting results indicated that steel waste-binder mixtures that were not briquetted immediately seemed to give strong briquettes after standing. To further test this hypothesis, the binder paste was added to thoroughly mixed steel waste $(200 \mathrm{~g}), \mathrm{Ca}(\mathrm{OH})_{2}(8 \mathrm{~g})$, and sodium bentonite $(6 \mathrm{~g})$, and the mixture was pelletized after several time intervals to determine the effect of hold time on the eventual strength (Table 13). Hold time did not seem to have much effect in this test.

\section{TABLE 13}

Pelletization of Premixed Steel Waste-Binder Mixture

\begin{tabular}{lcc}
\hline Time (hr) & Mixture (g) & Compressive Strength (psi) \\
\hline 1 & 25.8 & 204 \\
2 & 25.8 & 197 \\
3 & 25.8 & 210 \\
16 & 25.8 & 216 \\
\hline
\end{tabular}




\section{Silicate Binders}

Silicate binder was prepared by mixing $94 \mathrm{~g}$ of silicic acid $\left(85.5 \% \mathrm{SiO}_{2}, 14.5 \%\right.$ water) with $120 \mathrm{~g}$ of water and blending at top speed for 15 minutes (Binder S1). The results were compared with pellets prepared using purchased sodium silicate solution and silicic acid (Table 14).

TABLE 14

Silicate Binders

\begin{tabular}{|c|c|c|c|}
\hline $\begin{array}{l}\text { Additive } \\
\text { (g) }\end{array}$ & $\begin{array}{l}\text { Binder } \\
(\mathrm{g})\end{array}$ & $\begin{array}{l}\text { Water } \\
(\mathrm{g})\end{array}$ & $\begin{array}{l}\text { Drop } \\
\text { Test }\end{array}$ \\
\hline $\begin{array}{l}\text { Lime } \\
(1.6)\end{array}$ & $\begin{array}{c}\text { Sodium Silicate } \\
\qquad(0.5)\end{array}$ & - & Failed \\
\hline $\begin{array}{l}\text { Lime } \\
(1.6)\end{array}$ & $\begin{array}{c}\text { Sodium Silicate } \\
(0.5)\end{array}$ & - & Failed \\
\hline $\begin{array}{l}\text { Lime } \\
(1.5)\end{array}$ & $\begin{array}{c}\text { Sodium Silicate } \\
(0.5)\end{array}$ & 0.5 & Failed \\
\hline $\begin{array}{l}\text { Lime } \\
(1.5)\end{array}$ & $\begin{array}{c}\text { Sodium Silicate } \\
(0.5)\end{array}$ & 0.5 & Failed \\
\hline $\begin{array}{l}\text { Lime } \\
(1.6)\end{array}$ & $\begin{array}{l}\text { Silicic acid } \\
\qquad(0.8)\end{array}$ & 2 & Failed $^{1}$ \\
\hline $\begin{array}{l}\text { Lime } \\
(1.6)\end{array}$ & $\begin{array}{l}\text { Silicic acid } \\
\quad(0.8)\end{array}$ & 2 & Failed $_{1}$ \\
\hline $\begin{array}{l}\text { Lime } \\
(1.6)\end{array}$ & $\begin{array}{c}\text { Binder S1 } \\
(2.14)\end{array}$ & - & Failed $^{1}$ \\
\hline $\begin{array}{l}\text { Lime } \\
(1.6)\end{array}$ & $\begin{array}{c}\text { Binder S1 } \\
(2.14)\end{array}$ & - & Failed $^{1}$ \\
\hline
\end{tabular}

Sodium Silicate used is $14 \mathrm{wt} \% \mathrm{NaOH}$ and $27 \mathrm{wt} \% \mathrm{SiO}_{2}$.

${ }^{1}$ Pellet broke into two pieces.

\section{Aluminosilicate Binders}

A series of pellets was prepared using variations of an aluminosilicate gel as the binder. This material was known from our previous catalyst work to give a very hard material when dried, which is suitable for binding zeolites and clays. The gel is prepared from aluminum chloride and sodium silicate. The dried gel was mixed with $\mathrm{Ca}(\mathrm{OH})_{2}$, water, and steel waste. The 
$\mathrm{Ca}(\mathrm{OH})_{2}$ is needed to cement the gel and steel waste together. The pellets survived the drop test, but had a mediocre compressive strength compared to the molasses-OPC standard.

When the wet aluminosilicate gel (paste with a solids dry weight content of $10.7 \%$ ) was used with $\mathrm{Ca}(\mathrm{OH})_{2}$ and steel waste and water was removed to bring water content down to 6 wt $\%$ in the mixture, the resulting pellets were stronger (Table 15), but not in the class of the molasses standard. OPC mixed with the aluminosilicate gave less strong pellets, indicating that the $\mathrm{Ca}(\mathrm{OH})_{2}$ may be undergoing some cementitious reactions with the aluminosilicates.

When the wet gel and $\mathrm{Ca}(\mathrm{OH})_{2}$ were premixed and dried to lower water content, then mixed with the steel waste, again pellets with mediocre strength were obtained (Table 15). All these pellets had good immediate green strength.

TABLE 15

Results with Aluminosilicate Binder

\begin{tabular}{|c|c|c|c|c|}
\hline $\begin{array}{l}\text { Aluminosilicate } \\
\text { Gel }(\mathrm{g})\end{array}$ & $\begin{array}{l}\text { Additive } \\
\text { (g) }\end{array}$ & $\begin{array}{c}\text { Steel } \\
\text { Waste (g) }\end{array}$ & Method & $\begin{array}{l}\text { Compressive } \\
\text { Strength (psi) }\end{array}$ \\
\hline 1.6 & $\begin{array}{r}\text { Lime } \\
(1.6)\end{array}$ & 20 & Add dry gel, then $6 \mathrm{wt} \% \mathrm{H}_{2} \mathrm{O}$ & 165 \\
\hline 1.6 & $\begin{array}{l}\text { Lime } \\
(1.6)\end{array}$ & 20 & Add dry gel, then $6 \mathrm{wt} \% \mathrm{H}_{2} \mathrm{O}$ & 156 \\
\hline 1.6 & $\begin{array}{r}\text { Lime } \\
(1.6)\end{array}$ & 20 & $\begin{array}{l}\text { Add wet gel containing } 8 \text { wt } \% \\
\mathrm{H}_{2} \mathrm{O} \text {, then remove } \mathrm{H}_{2} \mathrm{O} \text { down to } \\
6 \mathrm{wt} \%\end{array}$ & 188 \\
\hline 1.6 & $\begin{array}{l}\text { Lime } \\
(1.6)\end{array}$ & 20 & $\begin{array}{l}\text { Add wet gel containing } 8 \text { wt } \% \\
\mathrm{H}_{2} \mathrm{O} \text {, then remove } \mathrm{H}_{2} \mathrm{O} \text { down to } \\
\qquad 6 \mathrm{wt} \%\end{array}$ & 194 \\
\hline 1.6 & $\begin{array}{l}\text { OPC } \\
(1.6)\end{array}$ & 20 & $\begin{array}{l}\text { Add wet gel containing } 8 \mathrm{wt} \% \\
\mathrm{H}_{2} \mathrm{O} \text {, then remove } \mathrm{H}_{2} \mathrm{O} \text { down to } \\
6 \mathrm{wt} \%\end{array}$ & 169 \\
\hline 1.6 & $\begin{array}{l}\mathrm{OPC} \\
(1.6)\end{array}$ & 20 & $\begin{array}{l}\text { Add wet gel containing } 8 \text { wt } \% \\
\mathrm{H}_{2} \mathrm{O} \text {, then remove } \mathrm{H}_{2} \mathrm{O} \text { down to } \\
\qquad 6 \mathrm{wt} \%\end{array}$ & 173 \\
\hline 1.6 & $\begin{array}{l}\text { Lime } \\
(1.6)\end{array}$ & 20 & $\begin{array}{l}\text { Mix wet gel and } \mathrm{Ca}(\mathrm{OH})_{2} \text {, dry to } \\
\text { remove excess } \mathrm{H}_{2} \mathrm{O} \text {, mix with } \\
\text { waste }\end{array}$ & 182 \\
\hline 1.6 & $\begin{array}{l}\text { Lime } \\
\text { (1.6) }\end{array}$ & 20 & $\begin{array}{l}\text { Mix wet gel and } \mathrm{Ca}(\mathrm{OH})_{2} \text {, dry to } \\
\text { remove excess } \mathrm{H}_{2} \mathrm{O} \text {, mix with } \\
\text { waste }\end{array}$ & 178 \\
\hline
\end{tabular}




\section{Iron Oxide Binders}

Iron hydroxyoxides or hydroxide hydrates resulting from reactions of iron(II) and (III) compounds convert rapidly into other iron oxide forms. Initial studies with combinations of $\mathrm{Ca}(\mathrm{OH})_{2}$ and $\mathrm{NaOH}$ with iron salts (nitrate and oxalate) set up to hard iron oxide mixtures. It was postulated that these mixtures could be used as a binder for the steel wastes, with the iron salts being generated by dissolution of steel waste in acid. Preliminary work has shown that a binder consisting of an iron hydroxyoxide (no cement) gave a pellet from steel mill waste that passed the drop test.

However, all combinations of the steel waste with the iron nitrate and $\mathrm{Ca}(\mathrm{OH})_{2}$ or $\mathrm{NaOH}$ failed to generate pellets that passed the drop test. Some of the pellets developed cured strengths in the 170-psi range, but the green strengths were poor. No further briquetting studies were done with the iron oxide binders; however, the iron salts proved to be extremely effective with molasses, as described in the following section.

\section{Molasses Additives}

The preparation of steel waste pellets with molasses binder was investigated to determine the effects of various additives to the molasses on binding strength. Initially the strength of pellets made with and without cement and $\mathrm{Ca}(\mathrm{OH})_{2}$ in the hand press were evaluated. These tests did not demonstrate any positive effect of the added cement and $\mathrm{Ca}(\mathrm{OH})_{2}$. Pyrolysis odor tests indicated that the odor produced from the heated pellets was more objectionable when the cement and $\mathrm{Ca}(\mathrm{OH})_{2}$ were present. Thus the calcium appeared to contribute substantially to the wet campfire odor.

To determine the effects of other metal cations on the molasses binding strengths and odors produced during heating, a series of salts was added to the molasses at $100^{\circ} \mathrm{F}$. On mixing the salt, a change in viscosity of the molasses was noted for several of the salts. In the case of aluminum and iron salts, the viscosity of the molasses-salt mixture was dramatically reduced. We have not found any explanation for this viscosity phenomenon. The highly fluid molasses-salt mixture was then mixed with the steel waste at $100^{\circ} \mathrm{F}$, and the pellets were formed in the hand press. Owing to the decreased viscosity, the waste material was wetted much more effectively than with straight, highly viscous molasses. Drop tests and compressive strengths determined for the pellets using molasses-salt binders are reported in Table 16.

\section{Ferric Nitrate Additive}

Compression tests of the cured pellets showed that addition of ferric nitrate $(1 \%$, dry weight basis) to molasses ( $8 \%$, wet weight basis) produced a superior pellet (avg. 396) compared with molasses alone (295). Increasing the amount of ferric nitrate to $3 \%$ gave much poorer results. This decrease in strength may be attributed to the increase in water added as the hydrate (see below). When calcium nitrate (1\%, dry weight basis) plus a small amount of water equivalent to that added as the hydrate in the iron nitrate salt were added to the molasses, the resulting cured pellet exhibited a much lower compressive strength. 
TABLE 16

Results from Metal Salt Additives to Molasses Binders.

\begin{tabular}{|c|c|c|c|c|c|c|c|c|}
\hline \multirow[b]{2}{*}{$\begin{array}{l}\text { Molasses } \\
\text { (g) }\end{array}$} & \multirow[b]{2}{*}{$\begin{array}{c}\text { OPC } \\
\text { (g) }\end{array}$} & \multirow[b]{2}{*}{$\begin{array}{l}\text { Lime } \\
(\mathrm{g})\end{array}$} & \multirow[b]{2}{*}{$\begin{array}{l}\mathrm{Fe}\left(\mathrm{NO}_{3}\right)_{3} \\
.9 \mathrm{H}_{2} \mathrm{O}(\mathrm{g})\end{array}$} & \multirow[b]{2}{*}{$\begin{array}{l}\mathrm{Ca}\left(\mathrm{NO}_{3}\right)_{2} \\
\cdot 4 \mathrm{H}_{2} \mathrm{O}(\mathrm{g})\end{array}$} & \multirow[b]{2}{*}{$\begin{array}{l}\text { Water } \\
(\mathrm{g})\end{array}$} & \multirow[b]{2}{*}{$\begin{array}{c}\text { Drop } \\
\text { Test }\end{array}$} & \multicolumn{2}{|c|}{$\begin{array}{l}\text { Compressive } \\
\text { Strength (psi) }\end{array}$} \\
\hline & & & & & & & Cured & Mean \\
\hline 1.6 & - & - & - & - & - & Passed & 299 & \\
\hline 1.6 & - & - & - & - & - & Passed & 291 & 295 \\
\hline 1.6 & - & - & 0.34 & - & - & Passed & 387 & \\
\hline 1.6 & - & - & 0.34 & - & - & Passed & 405 & 396 \\
\hline 1.6 & - & - & 1.36 & - & - & Passed & 236 & \\
\hline 1.6 & - & - & 1.36 & - & - & Passed & 242 & 239 \\
\hline 1.6 & - & - & - & 1.16 & 0.2 & Passed & 211 & \\
\hline 1.6 & - & - & - & 1.16 & 0.2 & Passed & 208 & 210 \\
\hline
\end{tabular}

The effect of water concentration on the cured pellet strengths was investigated for a few molasses-salt binder mixtures. In this series of tests (Table 17), the ferric nitrate with no added water was very strong (compressive strength $468 \mathrm{psi}$ ) compared with the same salt and a small amount of added water (312 psi). These results are consistent with many earlier studies showing that too much water is deleterious.

TABLE 17

Effect of Water Concentration on Molasses-Metal Salt Binders

\begin{tabular}{lcccccccc}
\hline $\begin{array}{l}\text { Molasses } \\
(\mathrm{g})\end{array}$ & $\begin{array}{c}\mathrm{OPC} \\
(\mathrm{g})\end{array}$ & $\begin{array}{c}\text { Lime } \\
(\mathrm{g})\end{array}$ & $\begin{array}{c}\mathrm{Fe}\left(\mathrm{NO}_{3}\right)_{3} \\
\cdot 9 \mathrm{H}_{2} \mathrm{O}(\mathrm{g})\end{array}$ & $\begin{array}{c}\mathrm{Ca}\left(\mathrm{NO}_{3}\right)_{2} \\
\cdot 4 \mathrm{H}_{2} \mathrm{O}(\mathrm{g})\end{array}$ & $\begin{array}{c}\text { Water } \\
(\mathrm{g})\end{array}$ & $\begin{array}{c}\text { Drop } \\
\text { Test }\end{array}$ & Cured & Mean \\
\hline 1.6 & - & - & 0.34 & - & 0 & Passed & 468 & \\
1.6 & - & - & 0.34 & - & 0 & Passed & 469 & 468 \\
1.6 & - & - & 0.34 & - & 0.46 & Passed & 315 & \\
1.6 & - & - & 0.34 & - & 0.46 & Passed & 308 & 312 \\
\hline
\end{tabular}


The compressive strengths of pellets made by adding metal salts to molasses-OPC and molasses $-\mathrm{Ca}(\mathrm{OH})_{2}$ binders were also investigated. These tests were also done using several water concentrations. The results (Table 18) show an effect similar to that observed with molasses-salt binders. Thus, the pellet using molasses-OPC with ferric nitrate (1\%) and no added water was significantly stronger (362 psi) than the pellet using molasses-OPC (282 psi), but the corresponding tests with added water showed little difference as a result of added salt.

In the case of molasses- $\mathrm{Ca}(\mathrm{OH})_{2}$-ferric nitrate binders (no water), the pellets again showed a significant increase in strength (240 psi) compared with the molasses- $\mathrm{Ca}(\mathrm{OH})_{2}$ pellets $(199$ psi). The pellets with added water showed a similar increase in strength resulting from the added ferric nitrate.

The addition of calcium nitrate to the molasses- $\mathrm{Ca}(\mathrm{OH})_{2}$ binder (water added) had a small negative effect on the compressive strengths of the resulting pellets. This effect is similar to that observed with the molasses-calcium salt binder. Addition of water to the molasses $-\mathrm{Ca}(\mathrm{OH})_{2}-$ calcium pellet showed further substantial decrease in strength.

A series of pellets was studied to determine if smaller amounts of molasses binder could be used as a result of the increased strength of the molasses-metal salt binders (Table 19). When only $4 \%$ molasses was used with the iron nitrate additive (no water), the strength was still adequate (avg. 226 psi). Addition of extra water to the $4 \%$ molasses-ferric nitrate binder increased the strength somewhat. Compressive strengths of the molasses- $\mathrm{Ca}(\mathrm{OH})_{2}-$ ferric nitrate binder at the low concentration were relatively low.

\section{Aluminum Nitrate Additives}

Aluminum nitrate was also very effective in decreasing the viscosity of molasses and gave very strong pellets. The result of several tests with molasses-aluminum nitrate at various concentrations are shown in Table 20 . The molasses-aluminum nitrate pellets were substantially stronger than the molasses pellets. The strength of the $6 \mathrm{wt} \%$ molasses-aluminum nitrate binder was comparable to that of the $8 \mathrm{wt} \%$ molasses binder, and the $4 \mathrm{wt} \%$ binder also gave pellets with adequate strength.

\section{Additional Binder Compositions}

A large number of pellets were produced by adding other salts (magnesium, calcium, aluminum, zinc, and ammonium) containing various anions. In this series of tests (Table 21), the aluminum nitrate, aluminum chloride, ferric nitrate, and ferric sulfate were the most effective of the salts. These also decreased the viscosity of the molasses to the greatest degree. Aluminum sulfate also produced the viscosity-reducing effect and gave strong pellets. Magnesium, calcium, and ammonium nitrates had little effect on the viscosity, but gave pellets with adequate strength in these tests. Sodium silicate and sodium carbonate increased the viscosity of the molasses, and had a small effect on the strength. Sodium chloride had the most negative effect on the strength. 
TABLE 18

Effect of Metal Salts and Water Concentrations on Molasses-OPC and Molasses-Lime Binders

Compressive Strength (psi)

Molasses OPC Lime $\mathrm{Fe}\left(\mathrm{NO}_{3}\right)_{3} \quad \mathrm{Ca}\left(\mathrm{NO}_{3}\right)_{2} \quad$ Water Drop

\begin{tabular}{|c|c|c|c|c|c|c|c|c|}
\hline (g) & (g) & (g) & - $9 \mathrm{H}_{2} \mathrm{O}(\mathrm{g})$ & $\cdot 4 \mathrm{H}_{2} \mathrm{O}(\mathrm{g})$ & (g) & Test & Cured & Mean \\
\hline 1.6 & 1.6 & - & - & - & - & Passed & 286 & \\
\hline 1.6 & 1.6 & - & - & - & - & Passed & 276 & 282 \\
\hline 1.6 & 1.6 & - & 0.34 & - & - & Passed & 367 & \\
\hline 1.6 & 1.6 & - & 0.34 & - & - & Passed & 356 & 362 \\
\hline 1.6 & 1.6 & - & - & - & 0.46 & Passed & 319 & \\
\hline 1.6 & 1.6 & - & - & - & 0.46 & Passed & 308 & 312 \\
\hline 1.6 & 1.6 & - & 0.34 & - & 0.46 & Passed & 319 & \\
\hline 1.6 & 1.6 & - & 0.34 & - & 0.46 & Passed & 312 & 316 \\
\hline 1.6 & - & 1.6 & - & - & - & Passed & 196 & \\
\hline 1.6 & - & 1.6 & - & - & - & Passed & 202 & 199 \\
\hline 1.6 & - & 1.6 & 0.34 & - & - & Passed & 234 & \\
\hline 1.6 & - & 1.6 & 0.34 & - & - & Passed & 246 & 240 \\
\hline 1.6 & - & 1.6 & - & - & 0.46 & Passed & 232 & $x$ \\
\hline 1.6 & - & 1.6 & - & - & 0.46 & Passed & 227 & 230 \\
\hline 1.6 & - & 1.6 & 0.34 & - & 0.46 & Passed & 107 & \\
\hline 1.6 & - & 1.6 & 0.34 & - & 0.46 & Passed & 105 & 106 \\
\hline 1.6 & - & 1.6 & 0.34 & - & 1.46 & Passed & 99 & \\
\hline 1.6 & - & 1.6 & 0.34 & - & 1.46 & Passed & 94 & 97 \\
\hline 1.6 & - & 1.6 & - & 0.29 & 0.51 & Passed & 200 & \\
\hline 1.6 & - & 1.6 & - & 0.29 & 0.51 & Passed & 202 & 201 \\
\hline 1.6 & - & 1.6 & - & 0.29 & 1.6 & Passed & 101 & \\
\hline 1.6 & - & 1.6 & - & 0.29 & 1.6 & Passed & 97 & 99 \\
\hline
\end{tabular}


TABLE 19

Effect of Molasses-Metal Salt Binder Concentrations

\begin{tabular}{lcccccc}
\hline & & & & & \multicolumn{2}{c}{ Compressive Strength (psi) } \\
\cline { 5 - 7 } $\begin{array}{l}\text { Molasses } \\
(\mathrm{g})^{\circ}\end{array}$ & $\begin{array}{c}\text { Lime } \\
(\mathrm{g})\end{array}$ & $\begin{array}{c}\mathrm{Fe}\left(\mathrm{NO}_{3}\right)_{3} \\
\cdot 9 \mathrm{H}_{2} \mathrm{O}(\mathrm{g})\end{array}$ & $\begin{array}{c}\text { Water } \\
(\mathrm{g})\end{array}$ & Drop Test & Cured & Mean \\
\hline 1.6 & - & 0.34 & 0 & Passed & 468 & \\
1.6 & - & 0.34 & 0 & Passed & 469 & 468 \\
0.8 & - & 0.34 & 0 & Passed & 234 & \\
0.8 & - & 0.34 & 0 & Passed & 218 & 226 \\
1.6 & - & 0.34 & 0.46 & Passed & 315 & \\
1.6 & - & 0.34 & 0.46 & Passed & 308 & 312 \\
0.8 & - & 0.34 & 0.46 & Passed & 233 & \\
0.8 & - & 0.34 & 0.46 & Passed & 257 & 245 \\
1.6 & 1.6 & 0.34 & 0.46 & Passed & 107 & \\
1.6 & 1.6 & 0.34 & 0.46 & Passed & 105 & 106 \\
0.8 & 0.8 & 0.34 & 0.46 & Passed & 117 & \\
0.8 & 0.8 & 0.34 & 0.46 & Passed & 125 & 121 \\
\hline
\end{tabular}

TABLE 20

Effect of Aluminum Nitrate and Molasses Concentrations

\begin{tabular}{lccccc}
\hline & & & & \multicolumn{2}{c}{ Compressive Strength (psi) } \\
\cline { 5 - 6 } $\begin{array}{l}\text { Molasses } \\
(\mathrm{g})\end{array}$ & $\begin{array}{c}\mathrm{Al}\left(\mathrm{NO}_{3}\right)_{3} \cdot 9 \mathrm{H}_{2} \mathrm{O} \\
(\mathrm{g})\end{array}$ & $\begin{array}{c}\text { Water } \\
(\mathrm{g})\end{array}$ & $\begin{array}{c}\text { Drop } \\
\text { Test }\end{array}$ & Cured & Mean \\
\hline 1.6 & - & - & Passed & 299 & \\
1.6 & - & - & Passed & 291 & 295 \\
1.6 & 0.17 & - & Passed & 352 & \\
1.6 & 0.17 & - & Passed & 346 & 349 \\
1.2 & 0.17 & - & Passed & 299 & \\
1.2 & 0.17 & - & Passed & 291 & 295 \\
0.8 & 0.17 & - & Passed & 183 & \\
0.8 & 0.17 & - & Passed & 195 & 189 \\
\hline
\end{tabular}

${ }^{1}$ Water was present in the hydrated salts used. 
TABLE 21

Results of Tests with Molasses-Salt Binders of Various Compositions

\begin{tabular}{|c|c|c|c|c|c|}
\hline \multirow[b]{2}{*}{$\begin{array}{l}\text { Molasses } \\
(\mathrm{g})\end{array}$} & \multirow[b]{2}{*}{$\begin{array}{l}\text { Salt }^{1} \\
(\mathrm{~g})\end{array}$} & \multirow[b]{2}{*}{$\begin{array}{l}\text { Water }^{2} \\
\text { (g) }\end{array}$} & \multirow[b]{2}{*}{$\begin{array}{l}\text { Drop } \\
\text { Test }\end{array}$} & \multicolumn{2}{|c|}{ Compressive Strength (psi) } \\
\hline & & & & Cured & Mean \\
\hline 1.6 & - & - & Passed & 315 & \\
\hline 1.6 & - & - & Passed & 315 & 315 \\
\hline 1.6 & $\begin{array}{l}\text { Aluminum chloride } \\
\mathrm{AlCl}_{3} \cdot 6 \mathrm{H}_{2} \mathrm{O}(0.34)\end{array}$ & - & Passed & 362 & \\
\hline 1.6 & $\begin{array}{l}\text { Aluminum chloride } \\
\mathrm{AlCl}_{3} \cdot 6 \mathrm{H}_{2} \mathrm{O}(0.34)\end{array}$ & - & Passed & 368 & 365 \\
\hline 1.6 & $\begin{array}{c}\text { Aluminum nitrate } \\
\text { Al }\left(\mathrm{NO}_{3}\right)_{3} \cdot 9 \mathrm{H}_{2} \mathrm{O}(0.34)\end{array}$ & 0 & Passed & 392 & \\
\hline 1.6 & $\begin{array}{c}\text { Aluminum nitrate } \\
\text { Al( }\left(\mathrm{NO}_{3}\right)_{3} \cdot 9 \mathrm{H}_{2} \mathrm{O}(0.34)\end{array}$ & 0 & Passed & 398 & 395 \\
\hline 1.6 & $\begin{array}{l}\text { Aluminum sulfate } \\
\mathrm{Al}_{2}\left(\mathrm{SO}_{4}\right)_{3}(0.2)\end{array}$ & 0.15 & Passed & 339 & \\
\hline 1.6 & $\begin{array}{l}\text { Aluminum sulfate } \\
\mathrm{Al}_{2}\left(\mathrm{SO}_{4}\right)_{3}(0.2)\end{array}$ & 0.15 & Passed & 330 & 334 \\
\hline 1.6 & $\begin{array}{l}\text { Ammonium nitrate } \\
\mathrm{NH}_{4} \mathrm{NO}_{3}(0.2)\end{array}$ & 0.14 & Passed & 320 & \\
\hline 1.6 & $\begin{array}{l}\text { Ammonium nitrate } \\
\mathrm{NH}_{4} \mathrm{NO}_{3}(0.2)\end{array}$ & 0.14 & Passed & 328 & 324 \\
\hline 1.6 & $\begin{array}{c}\text { Calcium nitrate } \\
\mathrm{Ca}\left(\mathrm{NO}_{3}\right)_{2} \cdot 4 \mathrm{H}_{2} \mathrm{O}(0.29)\end{array}$ & 0.05 & Passed & 369 & \\
\hline 1.6 & $\begin{array}{c}\text { Calcium nitrate } \\
\mathrm{Ca}\left(\mathrm{NO}_{3}\right)_{2} \cdot 4 \mathrm{H}_{2} \mathrm{O}(0.29)\end{array}$ & 0.05 & Passed & 366 & 368 \\
\hline 1.6 & $\begin{array}{c}\text { Ferric sulfate } \\
\mathrm{Fe}_{2}\left(\mathrm{SO}_{4}\right)_{3} \cdot \mathrm{nH}_{2} \mathrm{O}(0.29)\end{array}$ & 0.05 & Passed & 398 & \\
\hline 1.6 & $\begin{array}{c}\text { Fenric sulfate } \\
\mathrm{Fe}_{2}\left(\mathrm{SO}_{4}\right)_{3} \cdot \mathrm{nH}_{2} \mathrm{O}(0.29)\end{array}$ & 0.05 & Passed & 378 & 388 \\
\hline 1.6 & $\begin{array}{c}\text { Ferric citrate } \\
\mathrm{FeC}_{6} \mathrm{H}_{5} \mathrm{O}_{7} \cdot \mathrm{nH}_{2} \mathrm{O}(0.29)\end{array}$ & 0.05 & Passed & 312 & \\
\hline 1.6 & $\begin{array}{c}\text { Ferric citrate } \\
\mathrm{FeC}_{6} \mathrm{H}_{5} \mathrm{O}_{7} \cdot \mathrm{nH}_{2} \mathrm{O}(0.29)\end{array}$ & 0.05 & Passed & 323 & 318 \\
\hline 0.8 & $\begin{array}{c}\text { Ferric nitrate } \\
\mathrm{Fe}\left(\mathrm{NO}_{3}\right)_{3} \cdot 9 \mathrm{H}_{2} \mathrm{O}(0.34)\end{array}$ & 0.2 & Passed & 255 & \\
\hline 0.8 & $\begin{array}{l}\text { Ferric nitrate } \\
\mathrm{Fe}\left(\mathrm{NO}_{3}\right)_{3} \cdot 9 \mathrm{H}_{2} \mathrm{O}(0.34)\end{array}$ & 0.2 & Passed & 245 & 250 \\
\hline 1.6 & $\begin{array}{c}\text { Ferrous acetate } \\
\mathrm{Fe}\left(\mathrm{CH}_{3} \mathrm{COO}\right)_{2}(0.2)\end{array}$ & 0.14 & Passed & 307 & \\
\hline
\end{tabular}


TABLE 21 (continued)

\begin{tabular}{|c|c|c|c|c|c|}
\hline \multirow[b]{2}{*}{$\begin{array}{l}\text { Molasses } \\
(\mathrm{g})\end{array}$} & \multirow[b]{2}{*}{$\begin{array}{l}\text { Salt }^{1} \\
(\mathrm{~g})\end{array}$} & \multirow[b]{2}{*}{$\begin{array}{l}\text { Water }^{2} \\
\text { (g) }\end{array}$} & \multirow[b]{2}{*}{$\begin{array}{l}\text { Drop } \\
\text { Test }\end{array}$} & \multicolumn{2}{|c|}{ Compressive Strength (psi) } \\
\hline & & & & Cured & Mean \\
\hline 1.6 & $\begin{array}{c}\text { Ferrous acetate } \\
\mathrm{Fe}\left(\mathrm{CH}_{3} \mathrm{COO}\right)_{2}(0.2)\end{array}$ & 0.14 & Passed & 318 & 313 \\
\hline 1.6 & $\begin{array}{c}\text { Ferrous sulfate } \\
\mathrm{FeSO}_{4} \cdot 7 \mathrm{H}_{2} \mathrm{O}(0.34)\end{array}$ & & Passed & 335 & \\
\hline 1.6 & $\begin{array}{l}\text { Ferrous sulfate } \\
\mathrm{FeSO}_{4} \cdot 7 \mathrm{H}_{2} \mathrm{O}(0.34)\end{array}$ & - & Passed & 319 & 327 \\
\hline 1.6 & 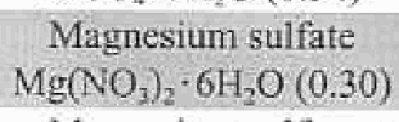 & 0.04 & Passed & 366 & \\
\hline 1.6 & $\begin{array}{c}\text { Magnesium sulfate } \\
\mathrm{Mg}\left(\mathrm{NO}_{3}\right)_{2} \cdot 6 \mathrm{H}_{2} \mathrm{O}(0.30)\end{array}$ & 0.04 & Passed & 369 & 368 \\
\hline 1.6 & $\begin{array}{l}\text { Sodium acetate } \\
\mathrm{Na}\left(\mathrm{CH}_{2} \mathrm{COO}\right)(0.2)\end{array}$ & 0.14 & Passed & 284 & \\
\hline 1.6 & $\begin{array}{c}\text { Sodium acetate } \\
\mathrm{Na}\left(\mathrm{CH}_{3} \mathrm{COO}\right)(0.2)\end{array}$ & 0.14 & Passed & 288 & 286 \\
\hline 1.6 & $\begin{array}{l}\text { Sodium carbonate } \\
\mathrm{Na} 2 \mathrm{CO} 3(0.2)\end{array}$ & 0.14 & Passed & 329 & \\
\hline 1.6 & $\begin{array}{l}\text { Sodium carbonate } \\
\mathrm{Na} 2 \mathrm{CO} 3(0.2)\end{array}$ & 0.14 & Passed & 332 & 330 \\
\hline 1.6 & $\begin{array}{l}\text { Sodium chloride } \\
\mathrm{NaCl}(0.2)\end{array}$ & 0.15 & Passed & 195 & \\
\hline 1.6 & $\begin{array}{l}\text { Sodium chloride } \\
\mathrm{NaCl}(0.2)\end{array}$ & 0.15 & Passed & 203 & 199 \\
\hline 1.6 & $\begin{array}{l}\text { Sodium nitrate } \\
\text { NaNO }_{3}(0.2)\end{array}$ & 0.15 & Passed & 286 & \\
\hline 1.6 & $\begin{array}{l}\text { Sodium nitrate } \\
\mathrm{NaNO}_{3}(0.2)\end{array}$ & 0.15 & Passed & 292 & 289 \\
\hline 1.6 & $\begin{array}{l}\text { Sodium silicate } \\
\qquad(0.5)\end{array}$ & 0 & Passed & 298 & \\
\hline 1.6 & $\begin{array}{l}\text { Sodium silicate } \\
\qquad(0.5)\end{array}$ & 0 & Passed & 316 & 307 \\
\hline 1.6 & $\begin{array}{l}\text { Sodium sulfate } \\
\mathrm{Na}_{2} \mathrm{SO}_{4}(0.2)\end{array}$ & 0.14 & Passed & 345 & \\
\hline 1.6 & $\begin{array}{l}\text { Sodium sulfate } \\
\mathrm{Na}_{2} \mathrm{SO}_{4}(0.2)\end{array}$ & 0.14 & Passed & 356 & 350 \\
\hline 1.6 & $\begin{array}{c}\text { Zinc sulfate } \\
\mathrm{ZnSO} \mathrm{O}_{4}+7 \mathrm{H}_{2} \mathrm{O}(0.34)\end{array}$ & 0 & Passed & 325 & \\
\hline 1.6 & $\begin{array}{l}\text { Zinc sulfate } \\
\mathrm{ZnSO}_{4} \cdot 7 \mathrm{H}_{2} \mathrm{O}(0.34)\end{array}$ & 0 & Passed & 316 & 320 \\
\hline
\end{tabular}

${ }^{1}$ Dry weight basis.

${ }^{2}$ Water was present in the hydrated salts used. 


\section{Briquetting}

The compositions and conditions for 35 briquetting tests are reported in Table 22 . The results of drop-shatter, compressive strength, and tumble testing are presented for the 35 briquetting tests in Table 23. The purpose of the test program was to develop a binder system that would produce steel mill waste briquettes with strength characteristics similar to briquettes made with the baseline binder system: $8 \mathrm{wt} \%$ OPC, $8 \mathrm{wt} \%$ molasses, and $4 \mathrm{wt} \%$ water. Progress made toward producing a suitable binder system is presented on a matrix-by-matrix basis.

\section{Matrix 1}

The binder systems evaluated in Matrix 1 consisted of various combinations of fly ash and $\mathrm{Ca}(\mathrm{OH})_{2}$ with and without sodium bentonite. The fly ash types evaluated included a Corrette Class C fly ash and a fly ash provided by Heckett Multiserv (Test 11). A single test (No. 12) was performed using a calcined form of the Heckett Multiserv fly ash. Tests 3 and 15 were performed with material recovered from previous briquetting tests that had air-dried for up to 20 hours . Two tests ( $8 \mathrm{~A}$ and $\mathrm{B}$ ) were performed to evaluate water alone as the binder system. All binder systems were compared against the baseline binder system (Test 14), which used sugar beet molasses from American Crystal Sugar (ACS) in East Grand Forks, MN.

Results of briquette evaluation indicated that briquettes made with the baseline binder system (OPC, molasses, water) had the highest tumble resistance by a considerable margin. After 7 days of air-drying (curing) the tumble recovery was approximately $72 \mathrm{wt} \%$ for the baseline briquettes. The Test 4 briquettes had the next highest value, approximately $48 \mathrm{wt} \%$, after 7 days. Additionally, the results indicate that the baseline binder system requires a shorter curing period to attain near maximum tumble resistance. After 2 days, the tumble recovery value was almost $69 \mathrm{wt} \%$ compared to $72 \mathrm{wt} \%$ after 7 days. Results of Tests 10,11 , and 12 show that their respective binder systems need longer than 3 days to achieve maximum tumble resistance. The compressive strength of briquettes produced with the baseline binder was at least $40 \%$ higher than values obtained with the other binder systems.

Moisture content appeared to be a critical variable affecting briquettability and strength. It was not possible to achieve a nominal roll torque of $700 \mathrm{ft}-\mathrm{lb}_{\mathrm{f}}$ when processing mixtures at $15 \mathrm{wt} \%$ water (Tests 5 and 9 ). The higher-moisture-content briquettes did not consistently release from the roll pockets, appeared to be less compacted, and tended to have a significant amount of fines adhered to their surface. Further, the higher moisture content contributed to significantly reduced tumble resistance and compressive strength relative to binder systems with lower moisture content. Water alone (Test 8B) as the binder system produced briquettes with tumble resistance higher than that of several of the binder systems, although the roll torque was considerably higher than desired.

Results further indicate that tumble resistance may be degraded by reducing sodium bentonite concentration and that the binder systems using Heckett Multiserv fly ash are less effective than those using the Corrette ash. 


\section{Matrix 2}

The binder systems evaluated in Matrix 2 included Corrette fly ash with $\mathrm{Ca}(\mathrm{OH})_{2}$ and/or sodium silicate. The fly ash concentrations were higher in Matrix 2 relative to Matrix 1 $(10,12$, and $14 \mathrm{wt} \%$ versus $8 \mathrm{wt} \%)$. Further, lower moisture contents were used $(4,6$, and $8 \mathrm{wt} \%$ versus 10 and $15 \mathrm{wt} \%$ ) in Matrix 2 to improve densification. A single briquetting test (No. 16) was performed with the baseline binder system using ACS sugar beet molasses.

The results of briquette evaluation indicated the baseline binder system was superior to the alternative binder systems investigated in Matrix 2. Briquettes made with baseline binder still had the highest tumble resistance, 67 versus $46 \mathrm{wt} \%$ (Test 24) after 6 days of air drying. Briquettes made with the baseline binder system also exhibited better drop-shatter resistance. The baseline binder briquettes principally exhibited only slight end deformation, with one briquette losing an estimated $20 \%$ of its mass. The other briquette types experienced greater levels of material loss with some individual briquettes (Tests $21,23,24)$, essentially disintegrating upon impact.

The addition of sodium silicate did not appear to impart significant improvement to briquette strength. However, comparison of Tests 18 and 20 suggests that substituting sodium silicate for $\mathrm{Ca}(\mathrm{OH})_{2}$ at a concentration of $4 \mathrm{wt} \%$ shortens the curing time required to achieve maximum tumble resistance.

Tumble resistance of baseline briquettes made with $-1 / 8$-in. steel mill waste was similar to that of baseline briquettes made with -16-mesh steel mill waste.

\section{Matrix 3}

The binder systems evaluated in Matrix 3 included various nitrate and sulfate salts and molasses provided by Heckett Multiserv. Water was used only in small concentration $(0.375 \mathrm{wt} \%)$ to substitute for the hydrate water of low-nitrate and -sulfate salt binder systems. A single briquetting test (No. 35) was performed with the baseline binder system using Heckett Multiserv molasses.

In contrast to Matrices 1 and 2, all binder systems except one (Test 32) produced briquettes with higher tumble resistance than the baseline briquettes produced using Heckett Multiserv molasses. Briquettes from Tests 25, 28, and 29, with molasses concentrations of $8 \mathrm{wt} \%$, exhibited tumble recovery values of approximately $92 \mathrm{wt} \%$. Even briquettes made with molasses alone (at $8 \mathrm{wt} \%$ ) had a tumble recovery of approximately $83 \mathrm{wt} \%$. These values compare to 74.4 wt $\%$ for the baseline briquettes, which also used $8 \mathrm{wt} \%$ molasses. Further, only the baseline briquettes exhibited deformation during drop-shatter testing. None of the other briquettes exhibited any degree of chipping.

The results of tumble tests repeated with briquettes from Test 14 (Matrix 1) indicated that ACS and Heckett Multiserv molasses produce briquettes with similar tumble resistance values (77 and $74 \mathrm{wt} \%$, respectively). 
The results of tumble testing also indicate that the curing time with the salt binder systems was essentially 2 days, although compressive strength results showed the briquettes increased in strength between 2 and 7 days. A check after completing tumbling tests on briquettes cured for 2 days showed that the rotational speed was slower than required ( $40 \mathrm{rpm})$. Adjustments were made to the rotational speed prior to tumble testing at the seventh day. As a consequence, the tumble recovery values obtained after 2 days of air curing were higher than values obtained after 7 days.

\section{TABLE 22}

Compositions and Conditions for Briquetting Steel Mill Waste

\begin{tabular}{|c|c|}
\hline Test No. & Binders $(w t \%)$ \\
\hline & $\mathrm{C} \operatorname{ash}^{1}+\mathrm{Ca}(\mathrm{OH})_{2}+$ water \\
\hline 1 & $(8) \quad(4) \quad(3)$ \\
\hline 2 & $\begin{array}{l}\mathrm{C} \text { ash }+\mathrm{Ca}(\mathrm{OH})_{2}+\text { sodium bentonite + water } \\
\begin{array}{llll}\text { (8) } & \text { (4) } & \text { (3) }\end{array}\end{array}$ \\
\hline 3 & Fines from Tests 1 and 2. No water added. \\
\hline 4 & $\begin{array}{l}\mathrm{C} \text { ash }+\mathrm{Ca}(\mathrm{OH})_{2}+\text { sodium bentonite + water } \\
\begin{array}{lll}\text { (8) } & \text { (4) } & \text { (3) }\end{array}\end{array}$ \\
\hline 5 & $\begin{array}{l}\mathrm{C} \text { ash }+\mathrm{Ca}(\mathrm{OH})_{2}+\text { sodium bentonite }+ \text { water } \\
\begin{array}{lll}\text { (8) } & \text { (4) } & \text { (3) }\end{array}\end{array}$ \\
\hline 6 & Fines from Tests 1 to 5 dried in 5 -gallon pail overnight. \\
\hline 7 & $\begin{array}{l}\mathrm{C} \text { ash }+\mathrm{Ca}(\mathrm{OH})_{2}+\text { sodium bentonite }+ \text { water } \\
\begin{array}{llll}(8) & \text { (4) } & \text { (2) }\end{array}\end{array}$ \\
\hline $8 \mathrm{a}$ & $\begin{array}{l}\text { Water } \\
(10)\end{array}$ \\
\hline $8 b$ & $\begin{array}{l}\text { Water } \\
\qquad(10)\end{array}$ \\
\hline 9 & $\begin{array}{l}\mathrm{C} \text { ash }+\mathrm{Ca}(\mathrm{OH})_{2}+\text { sodium bentonite + water } \\
\begin{array}{llll}\text { (8) } & \text { (4) } & \text { (3) } & \text { (15) }\end{array}\end{array}$ \\
\hline 10 & $\begin{array}{l}\text { Cash }+ \text { OPC + sodium bentonite + water } \\
\begin{array}{lll}\text { (8) } & \text { (4) } & \text { (2) }\end{array}\end{array}$ \\
\hline 11 & $\begin{array}{l}\mathrm{HM} \text { ash }+\mathrm{Ca}(\mathrm{OH})+\text { sodium bentonite + water } \\
\begin{array}{llll}(8) & \text { (4) } & \text { (2) }\end{array}\end{array}$ \\
\hline 12 & $\begin{array}{l}\text { HM calcined ash }+\mathrm{Ca}(\mathrm{OH})_{2}+\text { sodium bentonite + water } \\
\begin{array}{llll}\text { (8) } & \text { (4) } & \text { (2) }\end{array}\end{array}$ \\
\hline 13 & $\begin{array}{l}\mathrm{Ca}(\mathrm{OH})_{2}+\text { sodium bentonite + water } \\
(4)\end{array}$ \\
\hline 14 & $\begin{array}{l}\text { OPC + ACS molasses + water } \\
\begin{array}{lll}\text { (8) } & \text { (8) }\end{array}\end{array}$ \\
\hline 15 & Fines from Tests 1 to 9 dried on floor overnight. \\
\hline 16 & $\begin{array}{l}\text { OPC + ACS molasses + water } \\
\begin{array}{lll}(8) & (8) & (4)\end{array}\end{array}$ \\
\hline
\end{tabular}


TABLE 22 (continued)

\begin{tabular}{|c|c|}
\hline Test No, & Binders (wt $\%)$ \\
\hline \multirow[b]{2}{*}{17} & $\mathrm{C}$ ash $+\mathrm{Ca}(\mathrm{OH})_{2}+$ water \\
\hline & (12) (4) (8) \\
\hline \multirow[b]{2}{*}{18} & $\mathrm{Cash}+\mathrm{Ca}(\mathrm{OH})_{2}+$ water \\
\hline & $\begin{array}{lll}(12) & (4) & (6)\end{array}$ \\
\hline \multirow[b]{2}{*}{19} & $\mathrm{Cash}+\mathrm{Ca}(\mathrm{OH})_{2}+$ water \\
\hline & $(12) \quad(4) \quad$ (4) \\
\hline \multirow[b]{2}{*}{20} & C ash + sodium silicate + water \\
\hline & $\begin{array}{lll}(12) & (4) & (6)\end{array}$ \\
\hline \multirow[b]{2}{*}{21} & $\mathrm{C}$ ash $+\mathrm{Ca}(\mathrm{OH})_{2}+$ water \\
\hline & (14) $\quad(4) \quad(6)$ \\
\hline 22 & $\begin{array}{l}\mathrm{C} \text { ash }+\mathrm{Ca}(\mathrm{OH})_{2}+\text { water } \\
(10)\end{array}$ \\
\hline \multirow[b]{2}{*}{23} & $\mathrm{C}$ ash + sodium silicate + water \\
\hline & $(12) \quad(2) \quad$ (6) \\
\hline \multirow[b]{2}{*}{24} & $\mathrm{C}$ ash + sodium silicate $+\mathrm{Ca}(\mathrm{OH})_{2}+$ water \\
\hline & $\begin{array}{llll}(12) & (2) & (2) & (6)\end{array}$ \\
\hline \multirow[b]{2}{*}{25} & Ferric nitrate + HM molasses \\
\hline & (1) $\quad$ (8) \\
\hline \multirow[b]{2}{*}{26} & Ferric nitrate + HM molasses \\
\hline & (1) $\quad$ (4) \\
\hline \multirow[b]{2}{*}{27} & HM molasses \\
\hline & $(8)$ \\
\hline \multirow[b]{2}{*}{28} & Aluminum nitrate + HM molasses + water \\
\hline & $\begin{array}{lll}(0.5) & (6) & (0.375)\end{array}$ \\
\hline \multirow[b]{2}{*}{29} & Ferric nitrate + HM molasses + water \\
\hline & $\begin{array}{lll}(0.5) & (8) & (0.375)\end{array}$ \\
\hline \multirow[b]{2}{*}{30} & Fertic nitrate + HM molasses \\
\hline & $(1) \quad$ (6) \\
\hline \multirow[b]{2}{*}{31} & Ferrous sulfate + HM molasses \\
\hline & (1) $\quad(6)$ \\
\hline \multirow[b]{2}{*}{32} & Ferric sulfate $+\mathrm{HM}$ molasses \\
\hline & (1) $\quad(6)$ \\
\hline \multirow[b]{2}{*}{33} & Aluminum sulfate + HM molasses \\
\hline & (1) $\quad(8)$ \\
\hline \multirow[b]{2}{*}{34} & Ferrous sulfate + HM molasses + water \\
\hline & $\begin{array}{lll}(0.5) & (8) & (0.375)\end{array}$ \\
\hline & $\mathrm{OPC}+\mathrm{HM}$ molasses + water \\
\hline 35 & (8) $\quad(8) \quad(4)$ \\
\hline
\end{tabular}


$6 z$

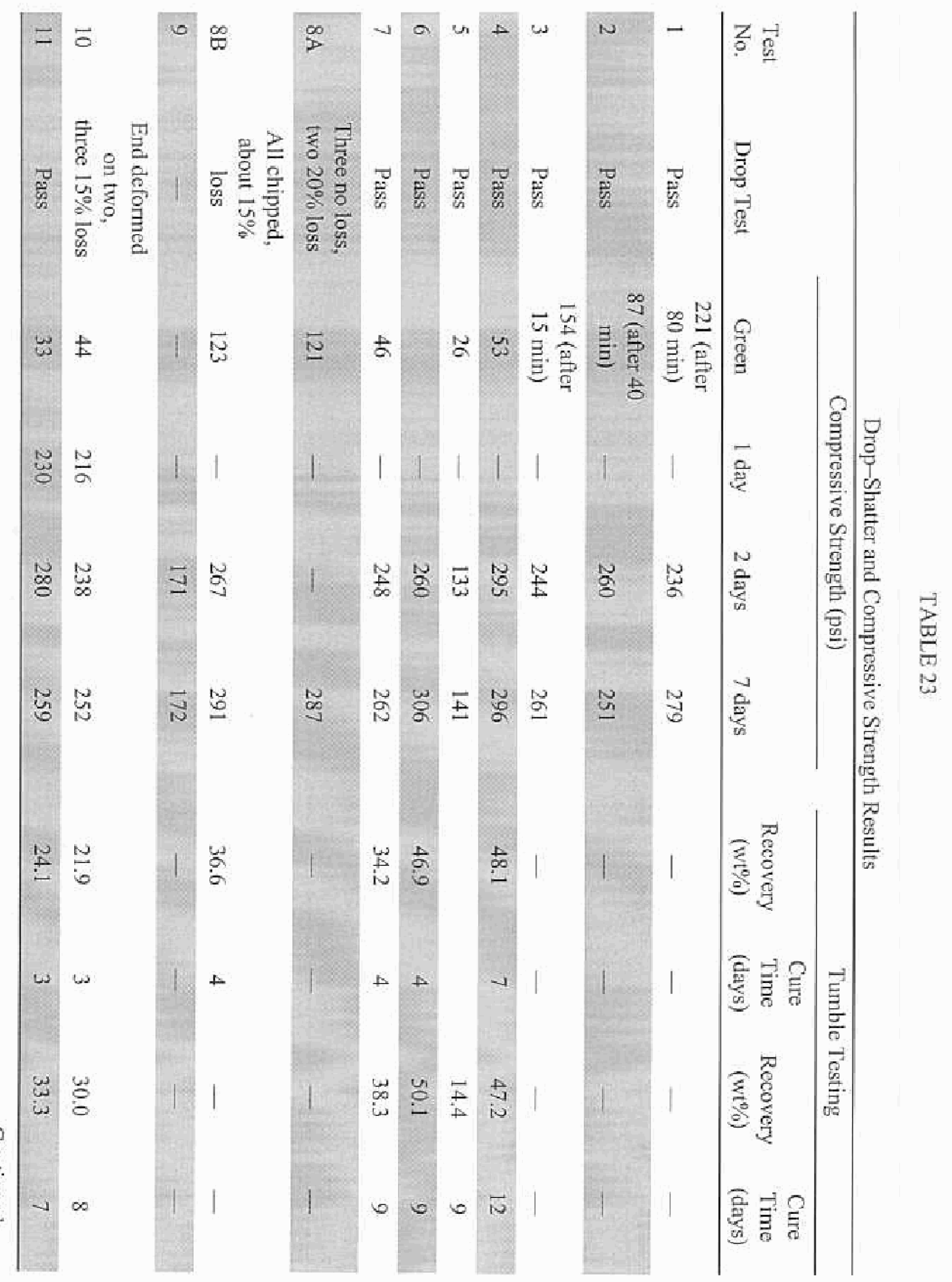




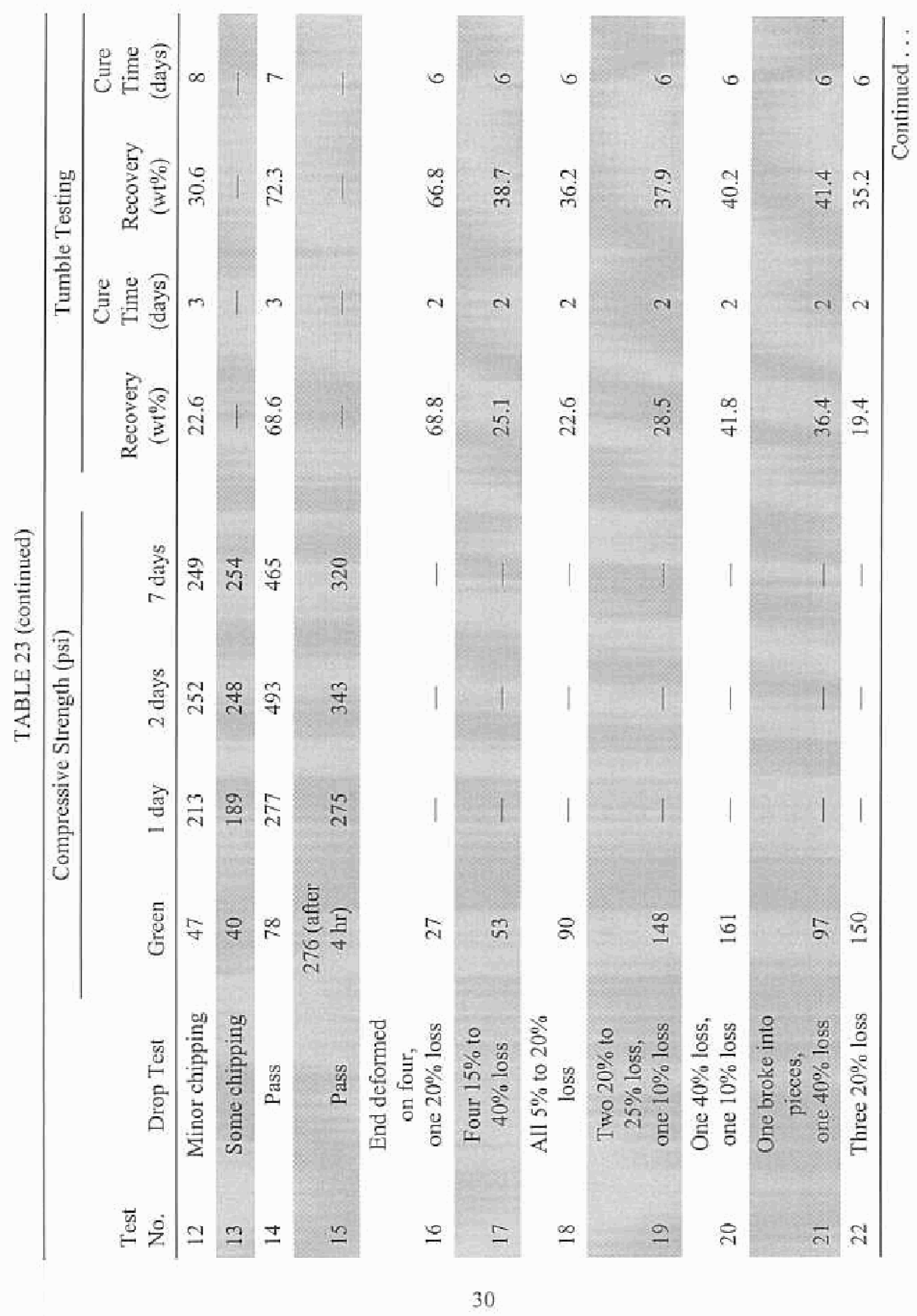




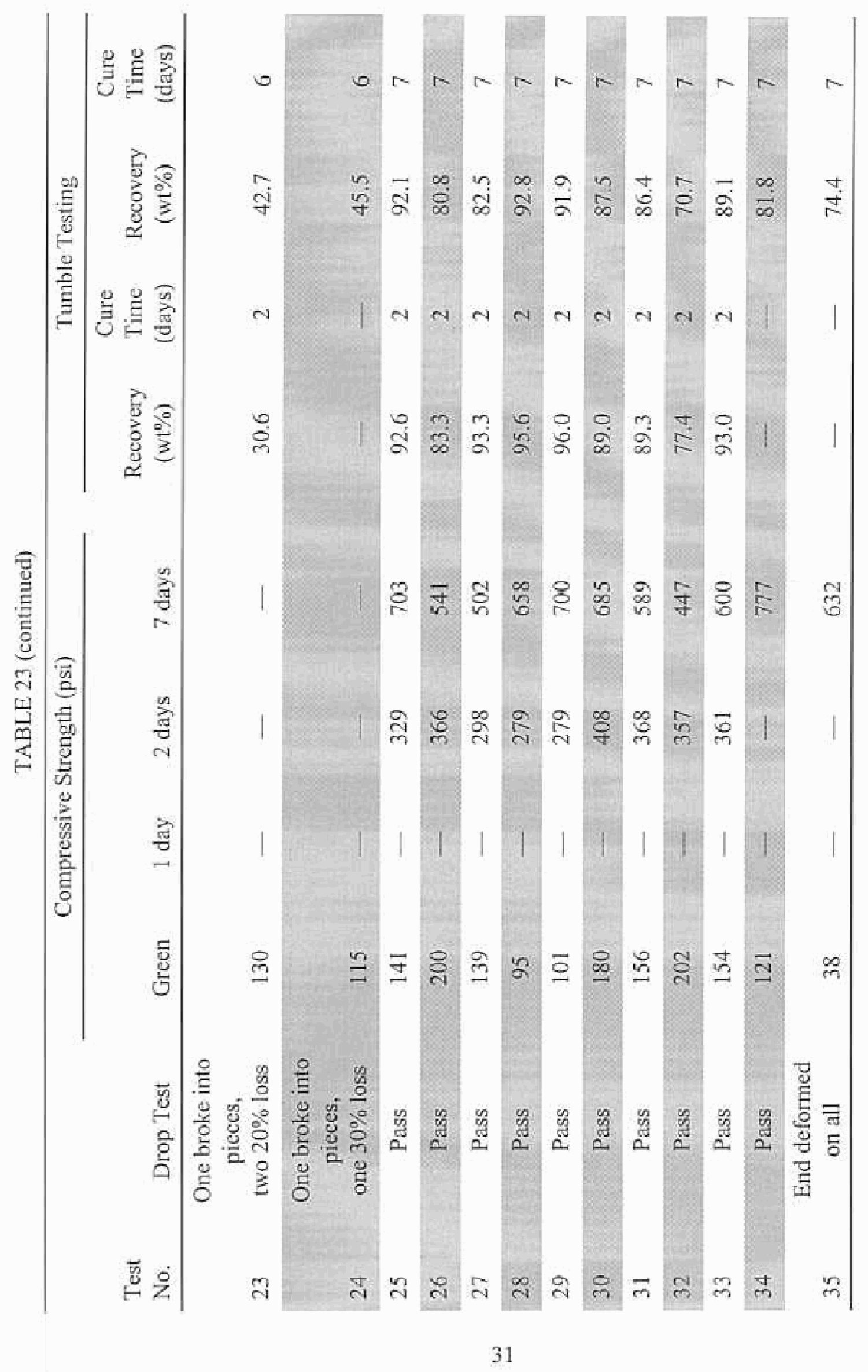




\section{Pyrolysis Odor Tests}

These tests were conducted in order to determine the effects of calcium on the peculiar odor that results from pyrolysis of the molasses-steel waste briquettes and the potential of oxidizers for elimination of odor resulting from the pellets containing molasses as the binder. The cured pellets were crushed to $1 / 4$-in. particles. The pieces were placed in a Vycor tube and heated in a tube furnace in a gentle flow of nitrogen. The effluent gas was smell-tested to compare the odors coming from the heated pellet. The heating was carried out in the temperature range of $24^{\circ}-600^{\circ} \mathrm{C}$ using a $10^{\circ} \mathrm{C} / \mathrm{min}$ heating rate. The odor of the gas was checked every $50^{\circ} \mathrm{C}$.

The results indicated that the iron and aluminum did not contribute to the wet campfire odor as did the calcium $\left(\mathrm{Ca}(\mathrm{OH})_{2}\right.$ and $\left.\mathrm{OPC}\right)$ (Table 24). The nitrate salt reduced the burned sugar odor considerably, probably by oxidizing the organic pyrolysis vapors to $\mathrm{CO}_{2}$.

\section{SEM Morphology}

Three of the pellets prepared with the molasses-metal salt binders were selected for scanning electron microscope (SEM) examination. These three samples and a briquette prepared with molasses-ferric nitrate binder and the molasses with no added salt were coated with carbon film for SEM morphology analysis. SEM images were scanned for interesting features, especially at the boundaries between particles. SEM data sheets are included in Appendix A.

\section{Molasses Binder Pellet Sample 980429}

An image (Figure 1) containing an imbedded $30-\mu \mathrm{m}$ sphere was examined. The white sphere was mainly Fe with small amounts of Ca oxide (1.1). The white lattice boundary (1.2) appears to be mostly $\mathrm{Fe}$ and $\mathrm{Ca}$ oxides (no evidence for carbohydrate). The grey boundary area (1.3) is similar, but contains some silicate and possibly carbohydrate or carbonate. Another grey area (1.4) contains less Fe but more $\mathrm{Al}, \mathrm{Mg}$, Si (slag-clay). The black area (1.5) is mostly carbon (coke). It is likely that the molasses is coating the particles, such that it cannot be found in particles.

A second image (Figure 2) contains numerous small (2-4- $\mu \mathrm{m})$ spheres of Fe (white) and a coke particle (2.1). The grey boundary areas (2.2 and 2.3) may contain carbohydrate in addition to the $\mathrm{Ca}$ and $\mathrm{Fe}$ present. The third image (Figure 3 ) contains various grey areas (3.1-3.5) with varying amounts of $\mathrm{Ca}, \mathrm{Fe}, \mathrm{S}, \mathrm{Si}$, and carbohydrate or carbonate.

It is clear from this and subsequent sets of images that the white areas are mostly Fe. The black areas are mostly a coke type of carbon.

\section{Molasses-Aluminum Nitrate Binder Pellet Sample 980428}

The first image (Figure 4) from this sample exhibits a variety of shapes and sizes of particles. A grey area (1.1) contains mainly Mg silicate with substantial carbonate or 
TABLE 24

Results of Pyrolysis Odor Tests

\begin{tabular}{|c|c|c|c|}
\hline $\begin{array}{l}\text { Additives } \\
\text { (g) }\end{array}$ & $\begin{array}{l}\text { Compressive } \\
\text { Strength } \\
\text { (psi) }\end{array}$ & $\begin{array}{c}\text { Temperature } \\
\left({ }^{\circ} \mathrm{C}\right)\end{array}$ & Odor \\
\hline Lime (1.6) & 315 & $\begin{array}{c}170-225 \\
250 \\
250-500 \\
500 \\
550\end{array}$ & $\begin{array}{l}\text { Very slight burnt sugar smell } \\
\text { Wet campfire smell } \\
\text { Campfire smell increased } \\
\text { Bumt smell started to decrease } \\
\text { Smell changed to burned wood (fireplace) and } \\
\text { got stronger }\end{array}$ \\
\hline $\begin{array}{l}\text { Lime }(1.6)+ \\
\mathrm{Fe}_{3} \mathrm{NO}_{3} .9 \mathrm{H}_{2} \mathrm{O} \\
(0.2)\end{array}$ & 384 & $\begin{array}{l}170-225 \\
\text { At } 250-300 \\
315 \\
340-500 \\
\text { At } 550 \\
\text { At } 600\end{array}$ & $\begin{array}{l}\text { Very light smell } \\
\text { Slight } \mathrm{NO}_{\mathrm{x}} \text { smell, no burn odor } \\
\text { Sweet garbage smell, white fumes } \\
\text { Slight burn smell } \\
\text { Light burnt smell } \\
\text { Strong burn smell }\end{array}$ \\
\hline $\begin{array}{l}\mathrm{Fe}\left(\mathrm{NO}_{3}\right)_{3} .9 \mathrm{H}_{2} \mathrm{O} \\
(0.34)+\mathrm{H}_{2} \mathrm{O} \\
(0.46)+\mathrm{OPC} \\
(1.6)\end{array}$ & 316 & $\begin{array}{l}250 \\
300\end{array}$ & $\begin{array}{l}\text { Slight burning smell } \\
\text { Burning garbage smell and white fumes that } \\
\text { became strong as the temperature increased to } \\
600^{\circ} \mathrm{C} \\
\text { Results similar to Test } 2 \text { except that the } \\
\text { intensity of the smell was less }\end{array}$ \\
\hline $\begin{array}{l}\mathrm{Fe}\left(\mathrm{NO}_{3}\right)_{3} .9 \mathrm{H}_{2} \mathrm{O} \\
(0.34)+\mathrm{H}_{2} \mathrm{O} \\
(0.46)\end{array}$ & 340 & $\begin{array}{c}255 \\
\text { At } 250-350 \\
350-425 \\
450\end{array}$ & $\begin{array}{l}\text { Sweet caramel smell } \\
\text { Same sweet caramel smell continued } \\
\text { Slight burning sugar smell } \\
\text { Onward buming sugar or fireplace smell }\end{array}$ \\
\hline $\begin{array}{l}\mathrm{Al}\left(\mathrm{NO}_{3}\right) \cdot \mathrm{NH}_{2} \mathrm{O} \\
(0.34)\end{array}$ & 395 & $\begin{array}{l}150 \\
200 \\
250 \\
300-365 \\
425 \\
500\end{array}$ & $\begin{array}{l}\text { Sweet smell } \\
\text { Sweet smell } \\
\text { Sweet smell } \\
\text { Slight caramel smell } \\
\text { Mild caramel smell } \\
\text { Mild caramel }\end{array}$ \\
\hline $\begin{array}{l}\mathrm{NH}_{4} \mathrm{NO}_{3} \\
(0.2)\end{array}$ & 324 & $\begin{array}{l}130 \\
213 \\
300 \\
350 \\
400 \\
500 \\
550\end{array}$ & $\begin{array}{l}\text { Ammonia smell began and became very strong } \\
\text { at } 145^{\circ} \mathrm{C} \\
\text { Fumes and burning paper smell was observed } \\
\text { Campfire smell although not as strong as with } \\
\text { molasses alone } \\
\text { Burning garbage smell } \\
\text { Smoking and burning garbage smell } \\
\text { Smoky and burning garbage smell became intense } \\
\text { Less smoky but strong buming garbage smell } \\
\text { persists }\end{array}$ \\
\hline
\end{tabular}




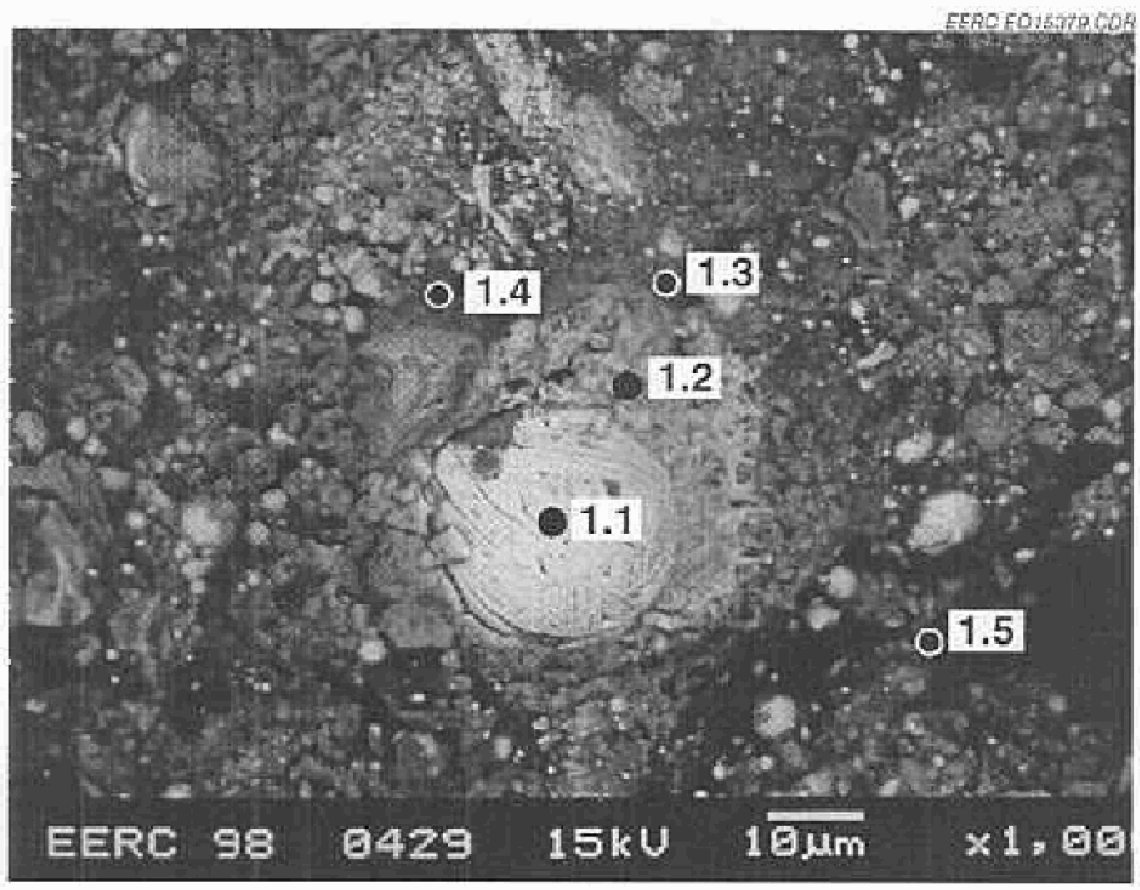

Figure 1 Molasses binder pellet - Image 1.

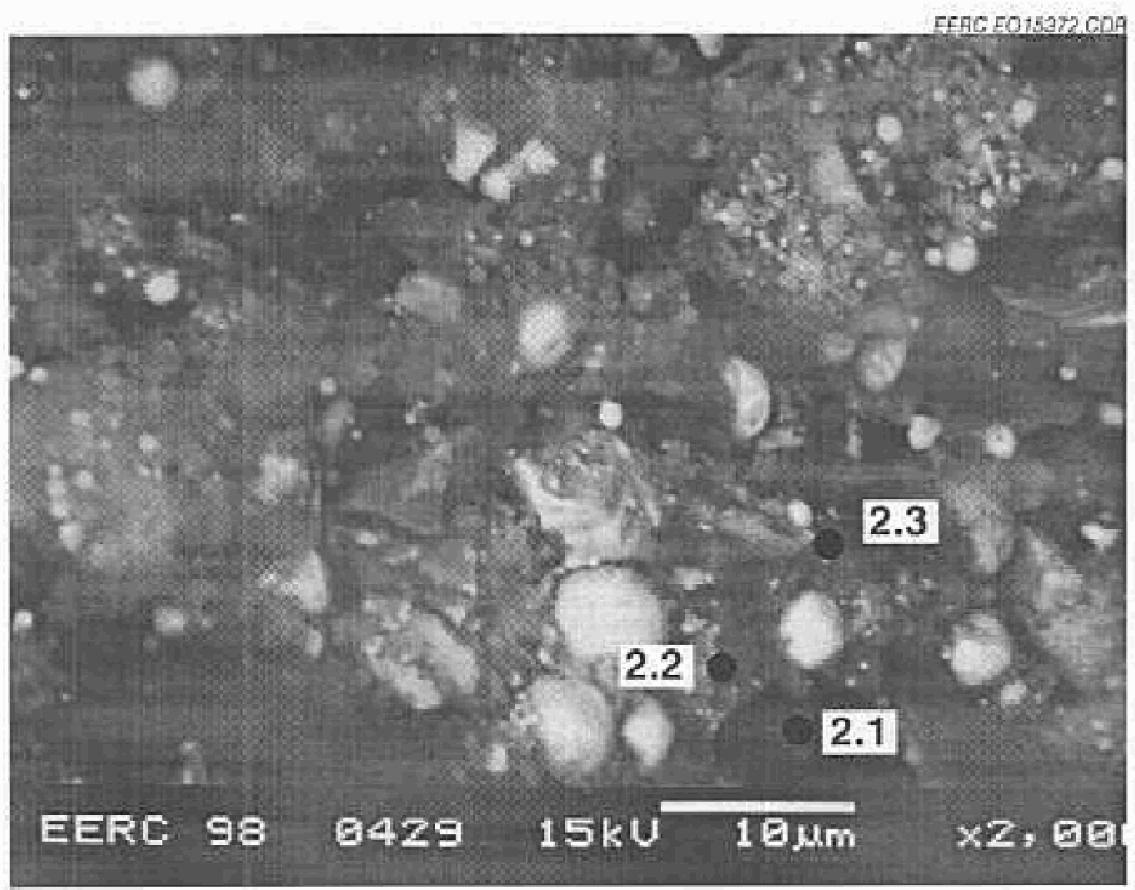

Figure 2. Molasses binder pellet - Image 2 . 


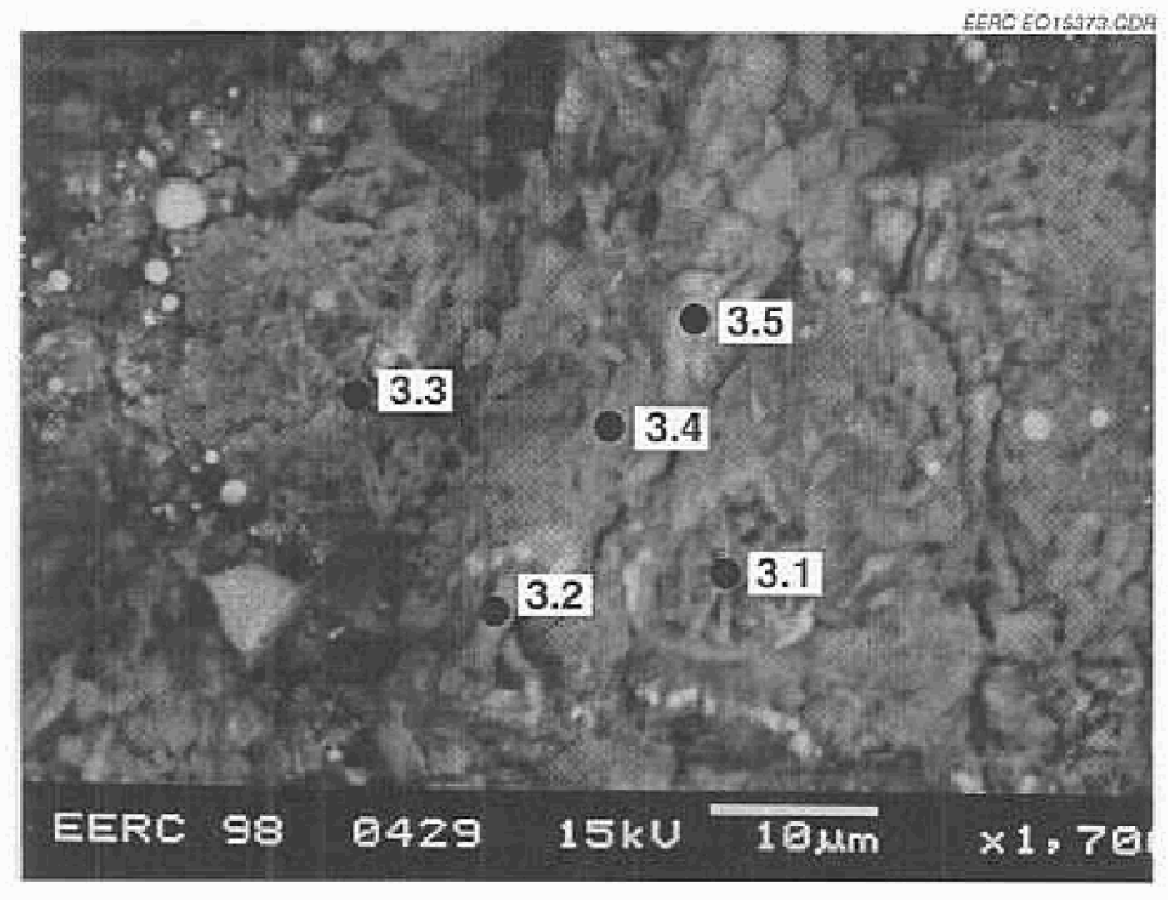

Figure 3. Molasses binder pellet - Image 3.

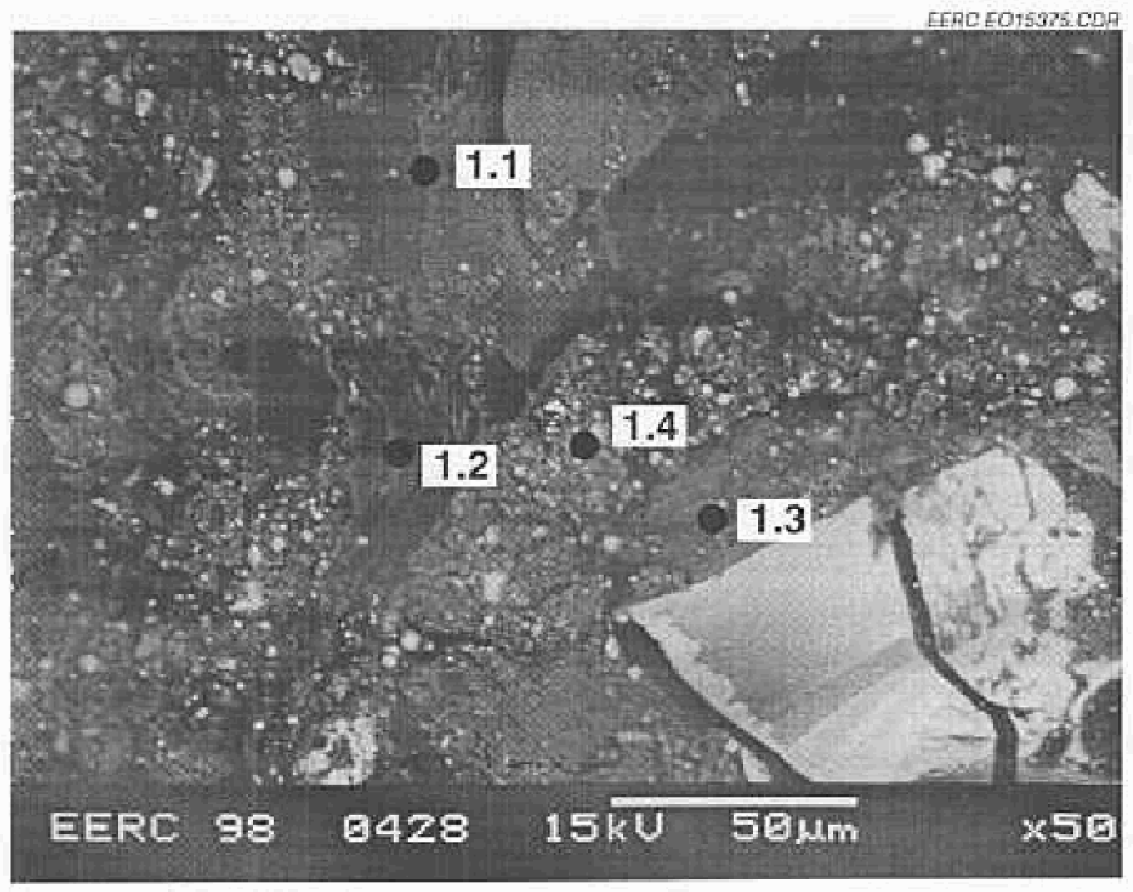

Figure 4. Molasses alumimum nitrate binder pellet - Image 1. 
carbohydrate. The $\mathrm{Al}$ content $(2.79 \%)$ is higher than that present in most other images of this and other samples. Another grey area (1.2) contains striations that may be from fracturing. The $\mathrm{K}$ and $\mathrm{Fe}$ contents were high, as was the carbonate or carbohydrate. This area also contains $\mathrm{Al}(1.89 \%)$ and some silicate and $\mathrm{Ca}$. Another grey area (1.3) is high in $\mathrm{Fe}$ and contains some $\mathrm{Ca}$ and carbonate or carbohydrate. A grey area (1.4) between the small white iron spheres is high in $\mathrm{Fe}$ and $\mathrm{Ca}$ and contains $\mathrm{Al}(1.99 \%)$ and carbonate or carbohydrate. No evidence was found for $\mathrm{N}$ (nitrate) in the composition data.

A second image (Figure 5) has a vesicular slag on a large black coke particle. The slag is mainly composed of $\mathrm{Ca}$ and sulfate but with some carbonate. $\mathrm{Al}$ is low, so the slag may have been on the coke and not formed in the binding.

A third image (Figure 6) from this sample shows a crevasse filled with radiating needle crystals (3.1) composed of $\mathrm{Ca}, \mathrm{Al}$, and silicate. These are identified as ettringite. The light matrix (3.3) is mainly $\mathrm{Ca}$ silicate. Since this composite particle was also found in a sample (980427) that was not treated with $\mathrm{Al}\left(\mathrm{NO}_{3}\right)_{3}$, and ettrigite was not found elsewhere in this sample, it is likely that the particle is a component of the steel waste and ettrigite was not formed during the binding process.

\section{Molasses-Ferric Nitrate Binder Pellet Sample 980427}

The first image (Figure 7) examined contains light triangular particles (1.1-1.2) in a darker grey matrix (1.3). A grey triangular particle (1.1) is mainly $\mathrm{Ca}$ and silicate, but contains some $\mathrm{Fe}$ and quite a bit of carbon (carbohydrate or carbonate). A lighter triangular particle (1.2) contains more $\mathrm{Fe}$ and much less $\mathrm{Ca}$ and silicate but similar carbon. The dark grey matrix (1.3) is similar in composition, but contains more $\mathrm{Fe}$. Although the white particle are mostly $\mathrm{Fe}$, it appears that $\mathrm{Fe}$ compounds are present in darker particles also. The evidence that $\mathrm{Fe}$ in the dark particles may represent added $\mathrm{Fe}$ is not at all conclusive because of the high $\mathrm{Fe}$ content in the waste particles. It is likely that the Fe from the binder is spread thinly around all the particles in the sample. No evidence was found for $\mathrm{N}$ (nitrate) in any of the images in any of the samples.

The second image (Figure 8) contains patches of lighter and darker particles. The darker grey (2.1) particles are high in $\mathrm{Fe}$ and contains $\mathrm{Ca}$ and $\mathrm{C}$. The lighter area (2.2) is high in $\mathrm{Pb}$, but also contains $\mathrm{Fe}, \mathrm{Ca}$, and $\mathrm{C}$. A third image (not shown) has radiating needle crystals of ettringite similar to those found in the molasses- $\mathrm{Al}\left(\mathrm{NO}_{3}\right)_{3}$ binder sample (980428).

\section{Molasses-Ferric Nitrate Binder Briquette Sample 980426}

The first image (Figure 9) of this sample contains a large coke particle (dark area, composition not given). The light grey area (1.1) off the edge of the large particle is mainly $\mathrm{Ca}$, but contains some $\mathrm{Fe}$ and carbonate or carbohydrate. Similar grey areas further away from the coke particle (1.2-1.3) have a variety of compositions.

The second image (Figure 10) shows another large coke particle and large iron particles. The grey areas between (2.1-2.2) are mainly $\mathrm{Ca}, \mathrm{Fe}$, and carbon. A lighter grey area is $\mathrm{Fe}$, 


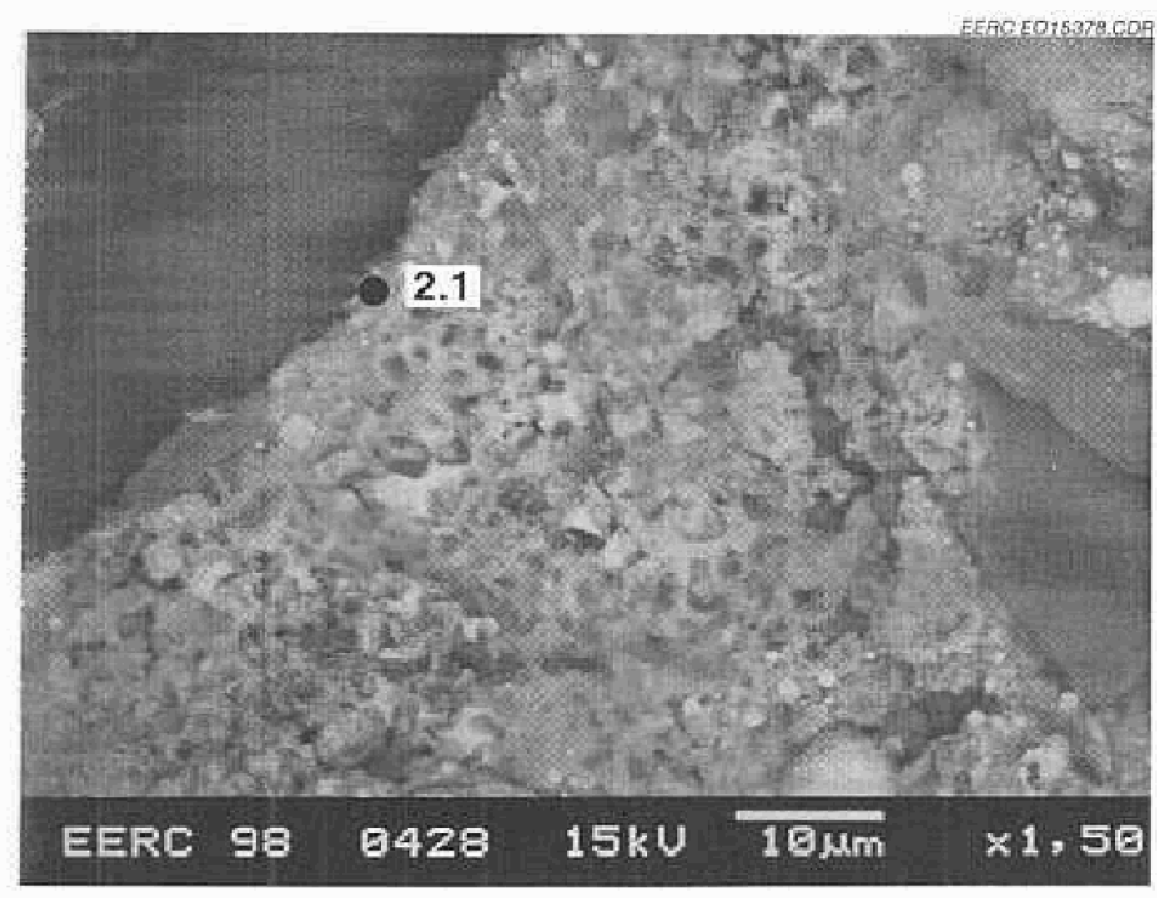

Figure 5. Molasses-aluminum nitrate binder pellet-Image 2.

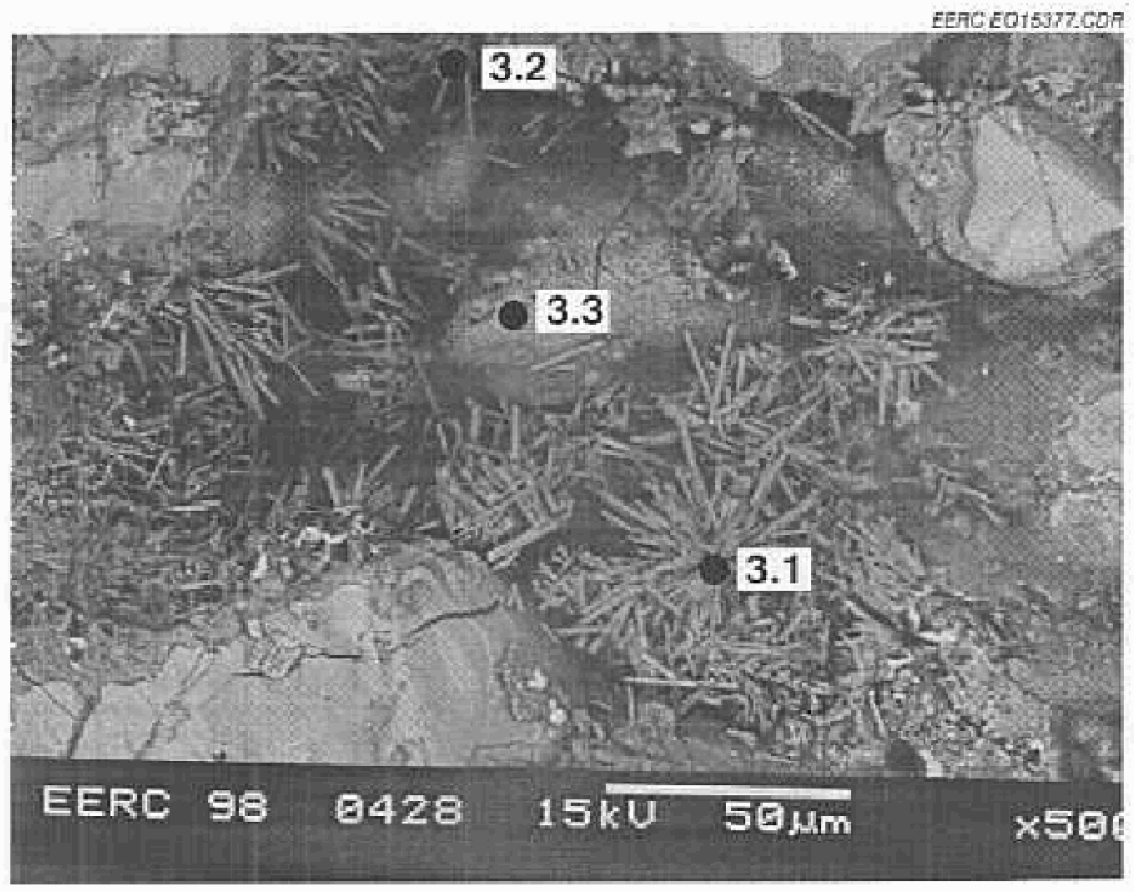

Figure 6. Molasses-aluminum nitrate binder pellet - Image 3. 


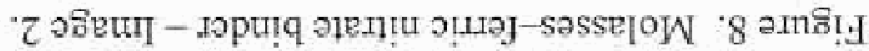

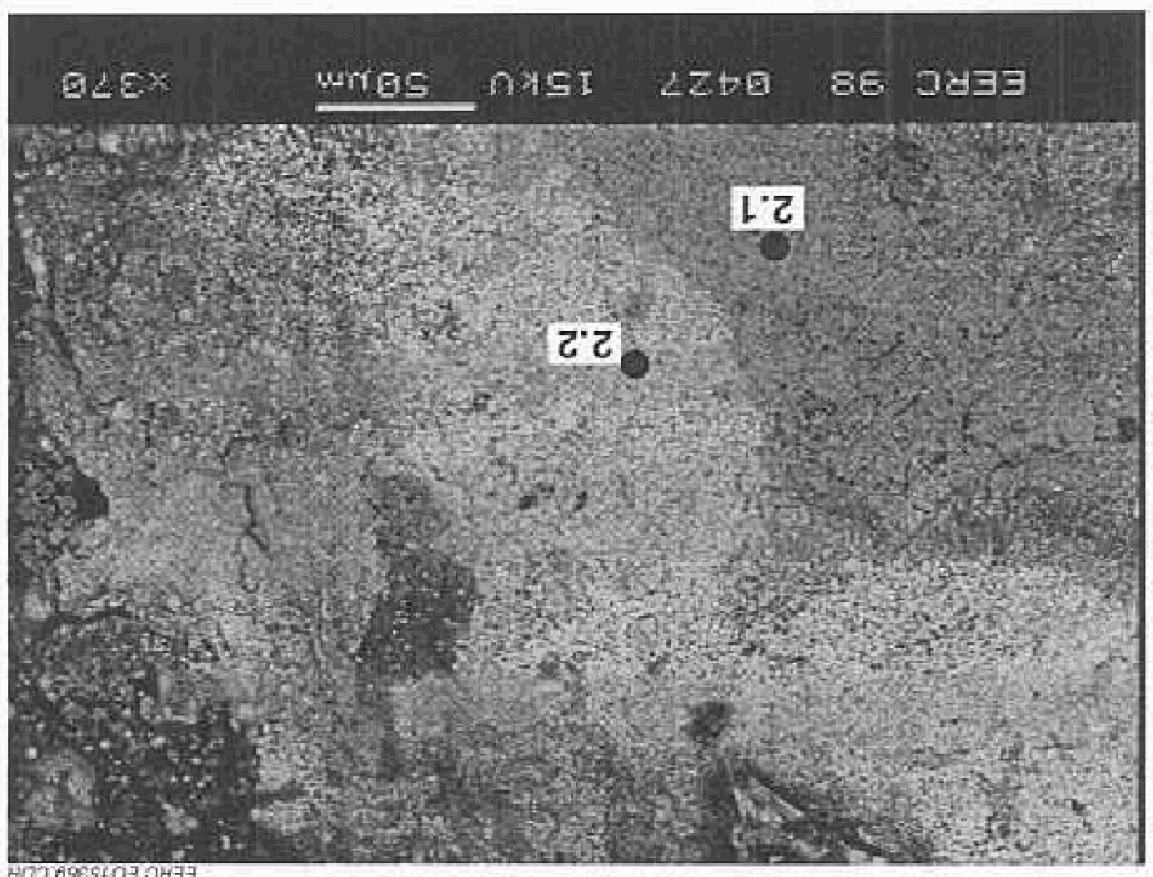

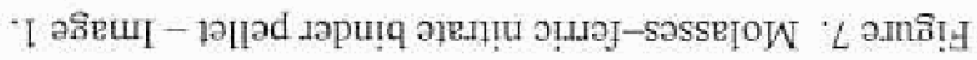

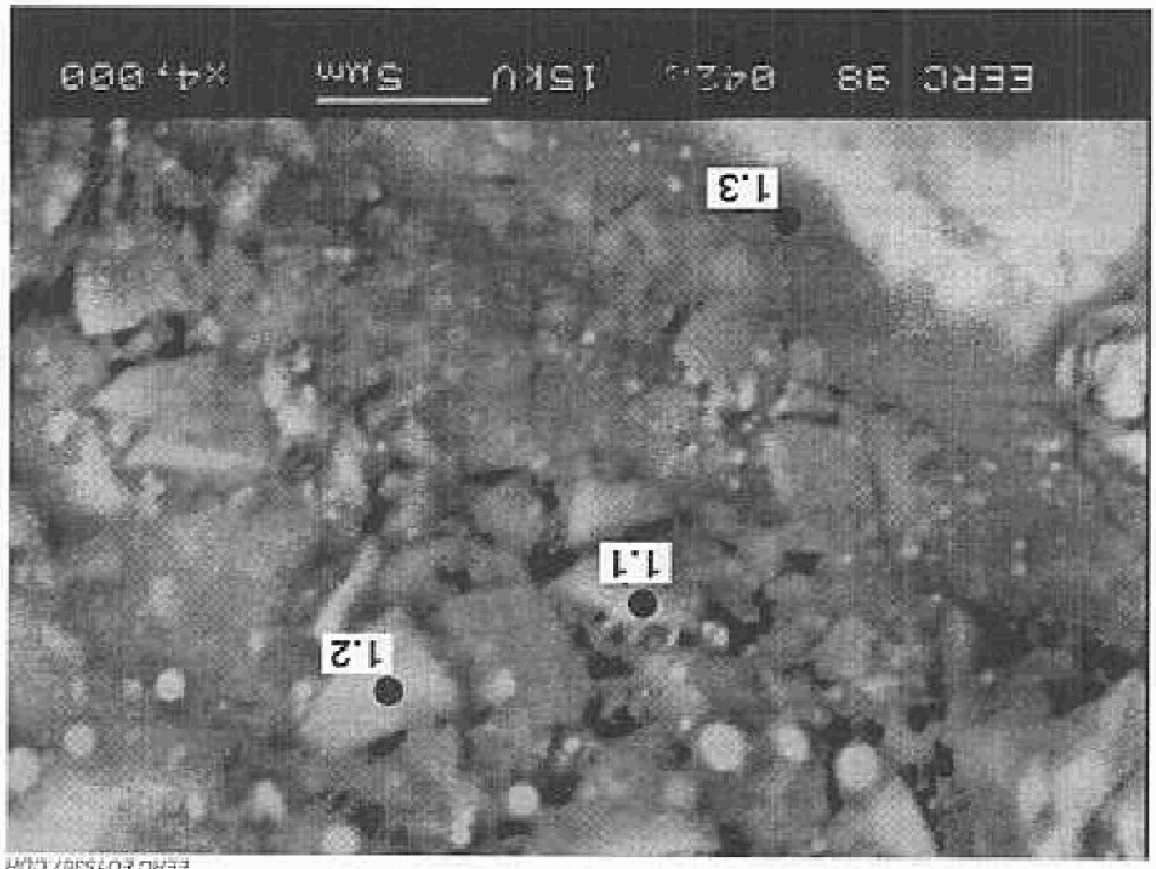

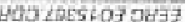




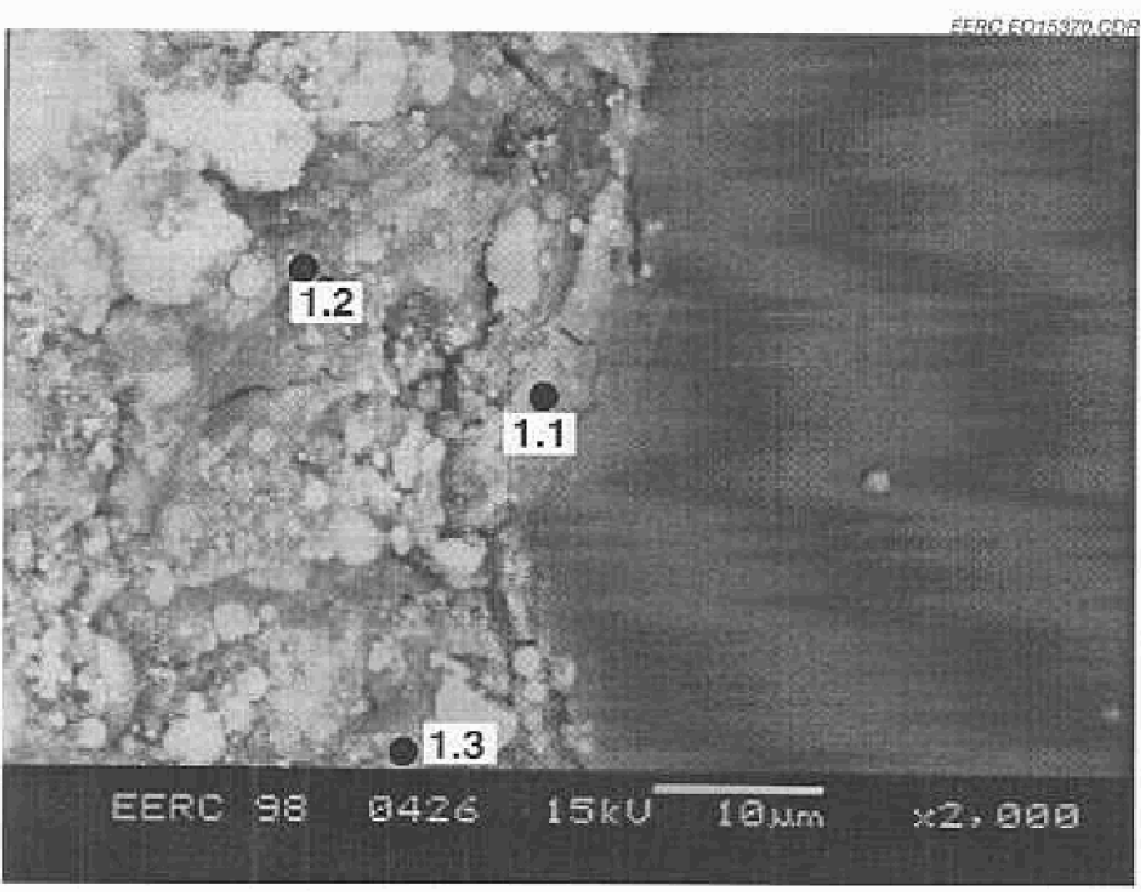

Figure 9. Molasses-ferric nitrate binder briquette - Image 1.

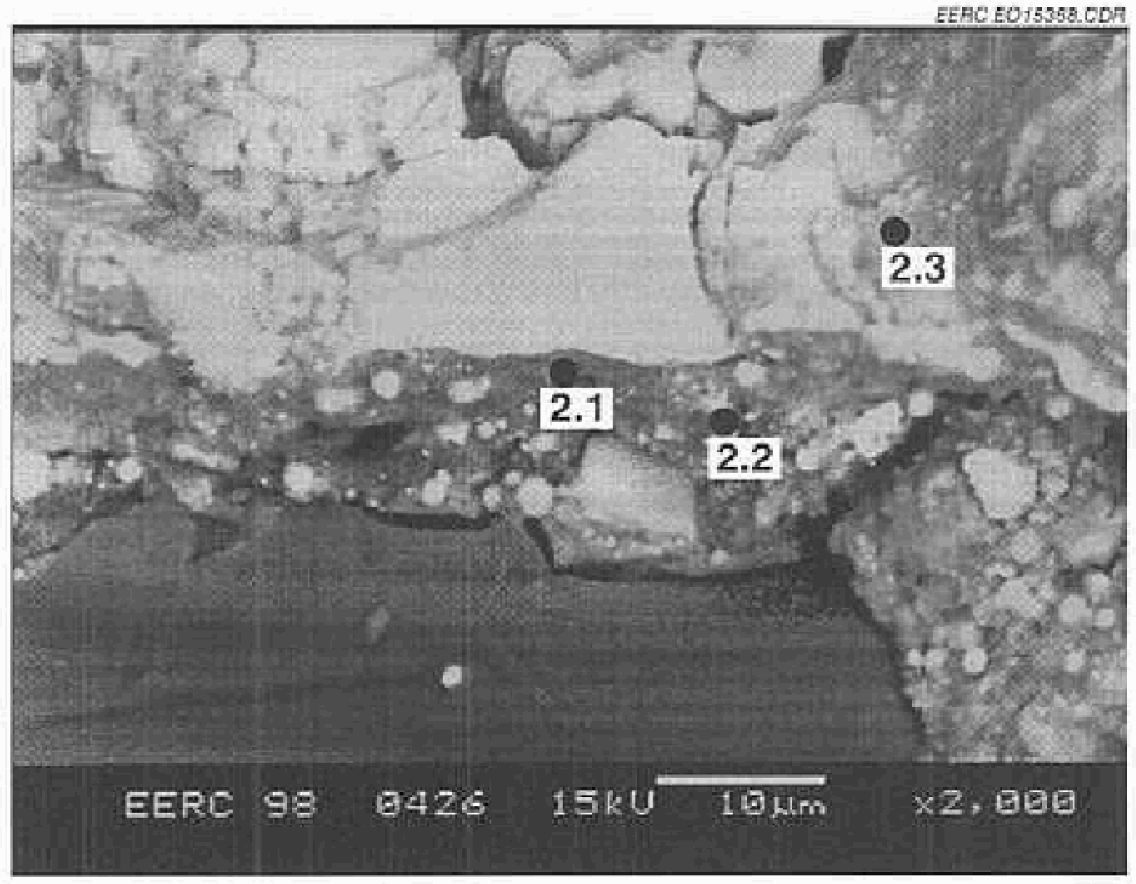

Figure 10. Molasses-ferric nitrate binder briquette-Image 2. 
silicate and carbonate or carbohydrate. A third inage (Figure 11) shows various grey areas between white Fe spheres. These are all mainly Ca, Fe, silicate, and carbonate or carbohydrate in somewhat different proportions. As in the previous sample, it is impossible to find a definitive layer of binder around the particulates.

\section{Molasses-Ferrous Sulfate Binder Pellet Sample 980430}

The first image (Figure 12) shows a grey area (1.2) with a relatively high S content that could correspond to a particle of $\mathrm{FeSO}_{4}$. Not all of the $\mathrm{FeSO}_{4}$ dissolved in the molasses, so this could be a remnant of the added salt. $\mathrm{A}$ second area (1.5) also shows a high $\mathrm{S}$ content. In the

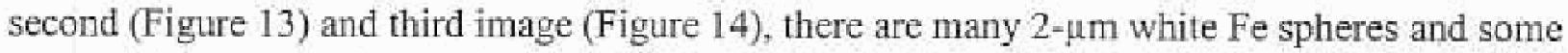
appearance of a grey film around the spheres. Analysis of the composition of grey areas indicated higher sulfate content.

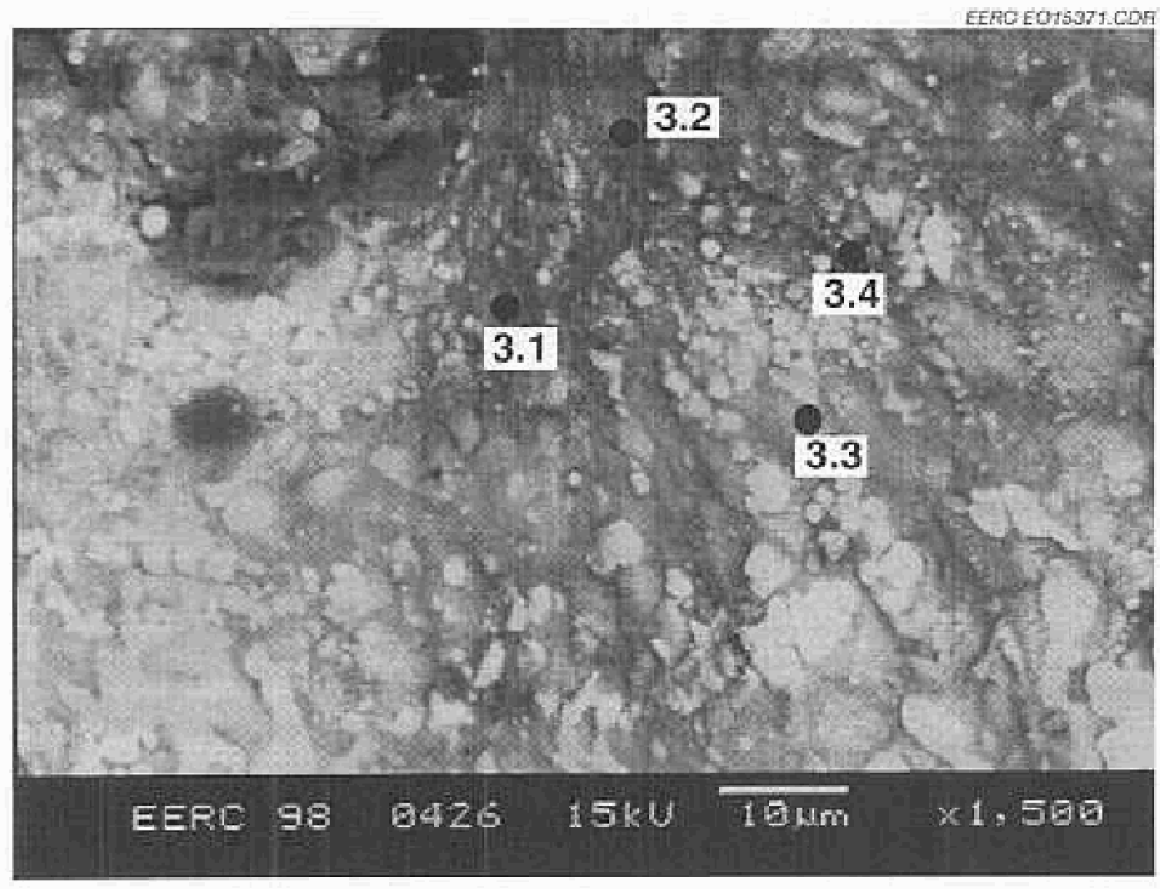

Figure 11. Molasses-ferric nitrate binder briquette - Image 3. 


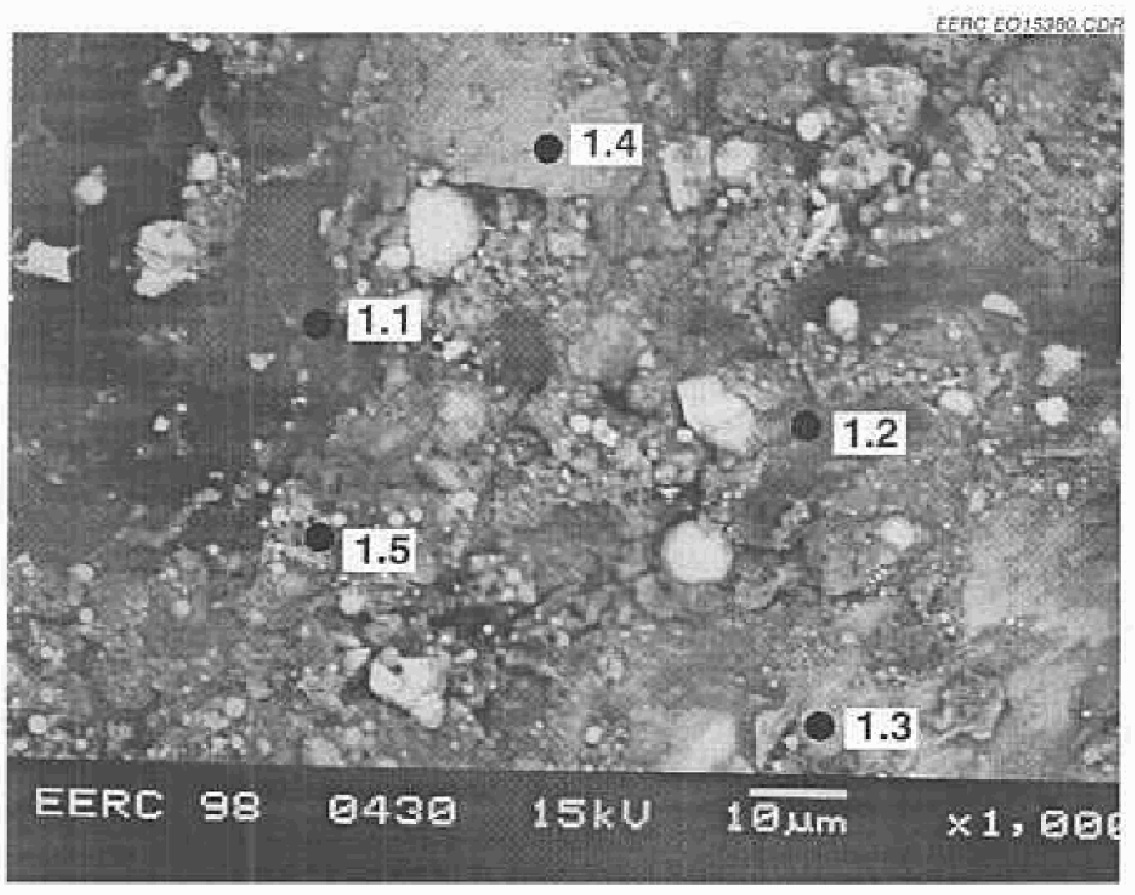

Figure 12. Molasses-ferrous sulfate binder pellet - Image 1.

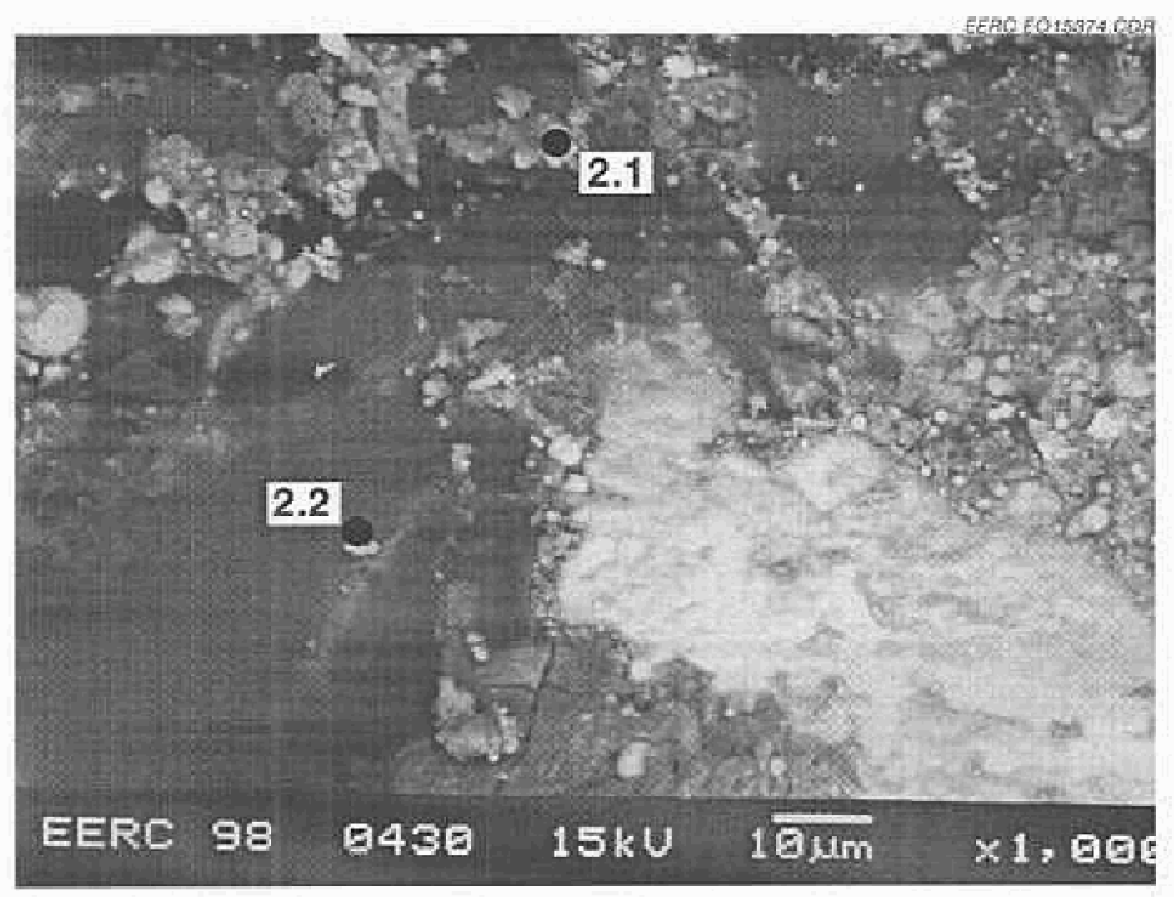

Figure 13. Molasses-ferrous sulfate binder pellet - Image 2. 


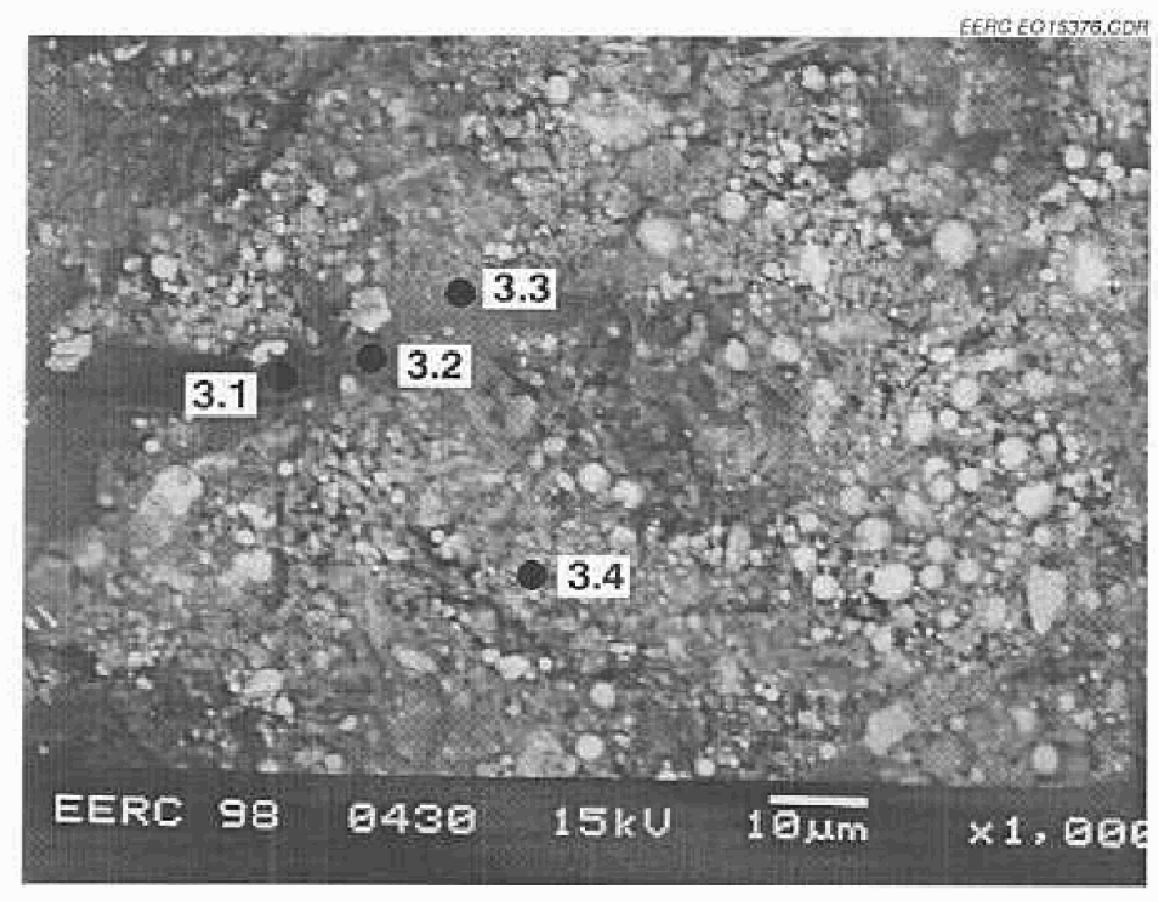

Figure 14. Molasses-ferrous sulfate binder pellet - Image 3.

\section{REFERENCES}

Aumônier, J. "Experimental Agglomeration of BOF Slurry," $I n$ Proceedings of The Institute for Briquetting and Agglomeration 24th Biennial Conference; Philadelphia, PA, Oct. 1995; pp $1-11$.

Gïnter, $\mathrm{H}_{*}$ "The Application of Waste Paper as a Binder in Pressure Agglomeration," In Proceedings of The Institute for Briquetting and Agglomeration 23 rd Biennial Conference; Seattle, WA, Oct. 1993; pp 25-34.

Lambert, R.C. "Techniques for Agglomerating Coal, Coke and Steel Mill Wastes," In Proceedings of The Institute for Briquetting and Agglomeration 24th Biennial Conference; Philadelphia, PA, Oct. 1995; pp 139-147.

Stecle, R.B. "Agglomeration of Steel Mill By-Products via Auger Extrusion," In Proceedings of The Institute for Briquetting and Agglomeration $23 \mathrm{rd}$ Biennial Conference; Seattle, WA, Oct. 1993; pp 205-217. 
APPENDIX A

SEM DATA SHEETS 


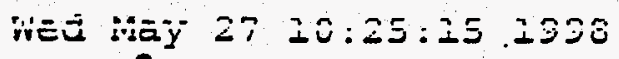

$98042 \% .1 .1$

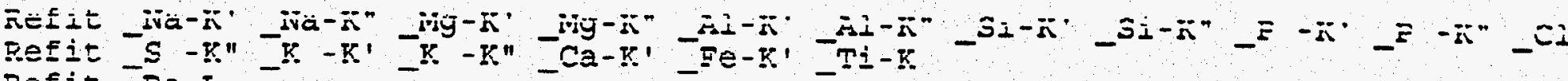

Refit Ba-L

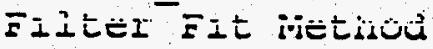

Chi-sqd = 10.84 Iivetime $=30.0$ sec.

Standardless Analysis

Eiement

$$
\begin{aligned}
& \text { Riative ETror } \\
& \text { k-ratio }
\end{aligned}
$$

$\mathrm{Na}-\mathrm{K} \quad 0.00180+1-0.00024$

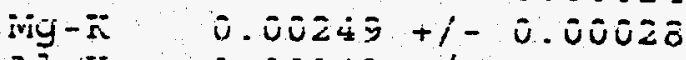

AI-K $\quad 0.00143+1-0.00034$

$S i-K \quad 0.00542+/-0.00048$

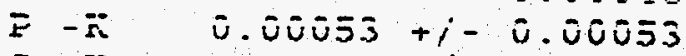

$S-\mathrm{R} \quad 0.01103+1-0.00080$

CI-F $\quad 0.00386+1-0.0008 I$

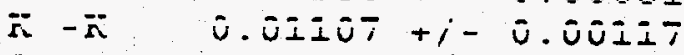

Ca-r. $\quad 0.11402+1-0.00400$

Fe-F $\quad 0.81863+/-0.01495$

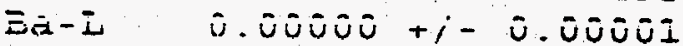

Ti-E $\quad 0.00000+1-0.00001$

$0-70.02972+1-0.00139$

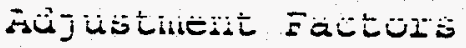

Z-Balance:

she11:

$\pi$
0.00000
1.00000

$\begin{array}{rr}\text { ivet } & \text { Drror } \\ \text { Counts }(1-\text { Sigma }) \\ 113+/- & 15 \\ 152+i- & 10 \\ 92+/- & 22 \\ 340+/- & 30 \\ 53+i- & 33 \\ 577+/- & 42 \\ 173+/- & 36 \\ 357+i- & 42 \\ 3567+/- & 125 \\ 9473+/- & 173 \\ 5+i- & 5 \\ 0+/- & 0 \\ 920+i- & 43\end{array}$

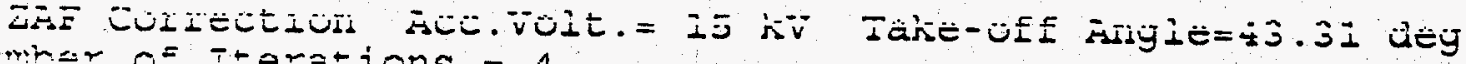

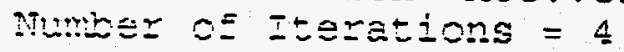

\begin{tabular}{|c|c|c|c|c|c|c|}
\hline 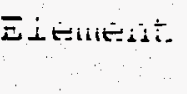 & 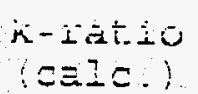 & ¿Ā & Atom & $\begin{array}{c}\text { Dientent } \\
\text { Nt } \Leftrightarrow\end{array}$ & 证 可计 & ivo. of \\
\hline Na- & 0.0017 & 3.004 & 1.02 & 0.51 & $+1-0.07$ & $\begin{array}{l}1.57 \% \\
1.57 \%\end{array}$ \\
\hline ivi $-\pi$ & บ.ธิธะ.ร & $=.124$ & $\bar{u} . \bar{s} \dot{q}$ & $\overline{0} . \overline{5}$ & $+i-\bar{u} . \bar{U}$ & 1.45T \\
\hline$\therefore-\Sigma$ & 0.0023 & 1.727 & 0.40 & 0.23 & $\div \% 0.06$ & $0.6 I I$ \\
\hline$=\square-\overline{-1}$ & $\therefore 051$ & ‥ 397 & $i . i 7$ & 071 & $+1-006$ & 1. 804 \\
\hline $\bar{F}-\bar{x}$ & ส.ดับัธ & 2.274 & $\bar{u} . \bar{u} \bar{y}$ & $\bar{u} \cdot \bar{u} \bar{s}$ & $\bar{U} \cdot \bar{u} \bar{s}$ & $\overline{1} .145$ \\
\hline$\Xi-E$ & $0.220=$ & 1.126 & 1.62 & 2.17 & 0.29 & 2.502 \\
\hline$-7-\bar{n}$ & $\because \quad 35$ & 1.105 & $0 . \equiv 2$ & 640 & 0.08 & 0805 \\
\hline$\ddot{r}-\ddot{x}$ & 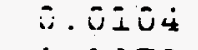 & ט.シラ & I. $\Sigma \bar{Z}$ & I. & $\bar{U} . i \bar{I}$ & I. \\
\hline$\because \equiv-\Xi$ & $\therefore .2073$ & 0.955 & 91.77 & 23.25 & 0.36 & 18.189 \\
\hline $\bar{z}=-\ddot{r}$ & $\therefore 7704$ & 1.035 & 55.67 & $\because \Xi 72$ & 1. . 45 & 101.504 \\
\hline $\bar{E} \dot{x}-2$ & シ. & $1.15 \overline{0}$ & $\bar{u} \cdot \bar{u} \bar{u}$ & $\bar{u} . \bar{u}$ & $+i-\bar{u} . \bar{u}$ & $\dot{U} \cdot \bar{U} \dot{U}$ \\
\hline 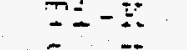 & 2.000 & 3.998 & 0.20 & 2.00 & $+1-0.00$ & 0.000 \\
\hline$\because \quad-\bar{r}$ & $\therefore \quad 05$ & $I .531$ & 15.53 & 5 & $-1-0.25$ & -- \\
\hline ーニここー & & & ت & تن ت ن & & \\
\hline
\end{tabular}

The muber of cation results are based uoon 24 oxven atoms 


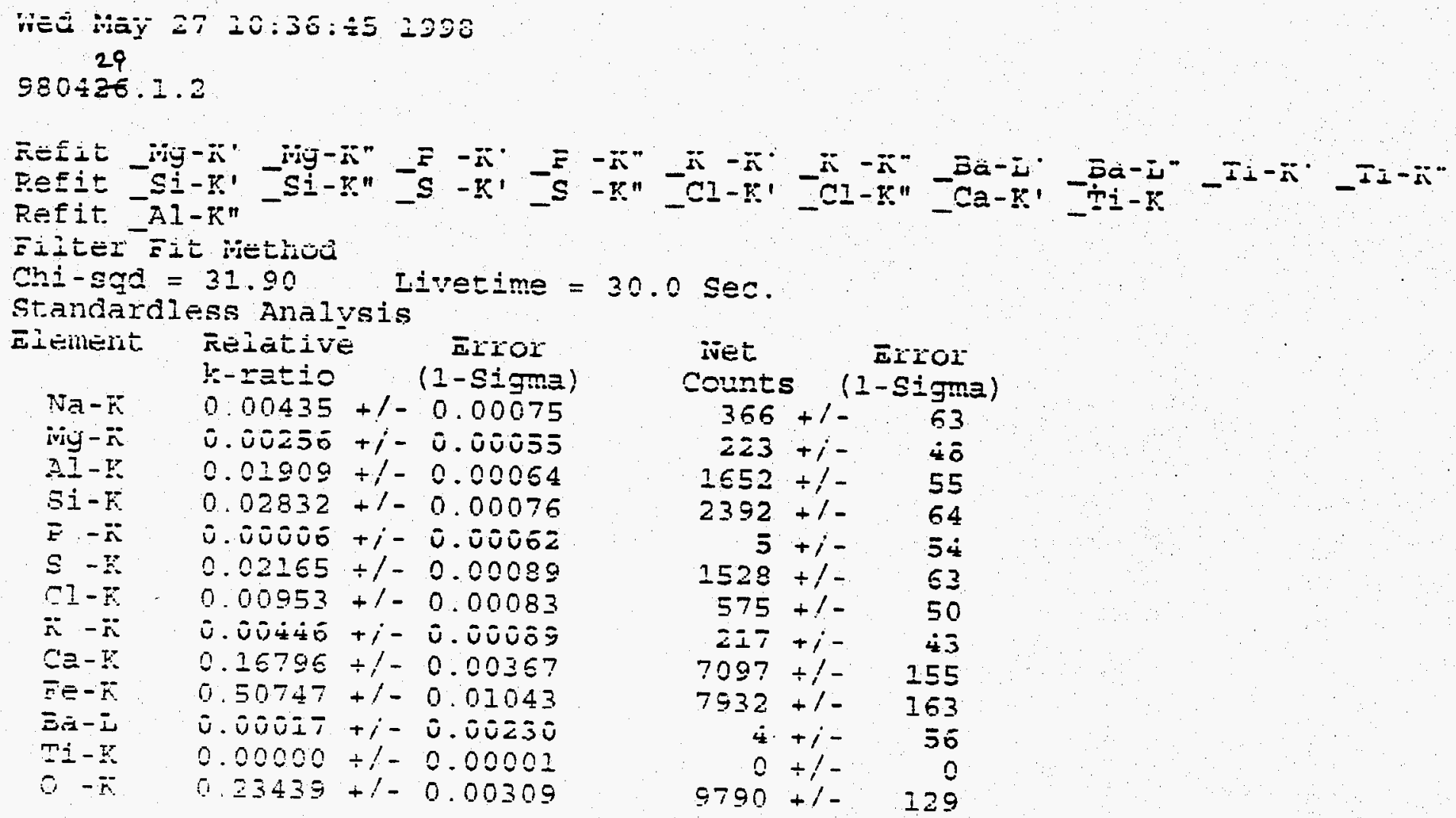

ivet Counts (1-sigma)

$\begin{array}{rr}366+1- & 63 \\ 223+i- & 40 \\ 1652+/- & 55 \\ 2392+1- & 64 \\ 5+i- & 54 \\ 1528+1- & 63 \\ 575+1- & 50 \\ 217+i- & 43 \\ 7097+1- & 155 \\ 7532+1- & 163 \\ 4+i- & 55 \\ 0+i- & 0 \\ 9790+i- & 129\end{array}$

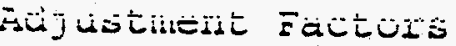
$z-$ Eai ance:

She11:
0.00000
1. 00000
0.00000
00000

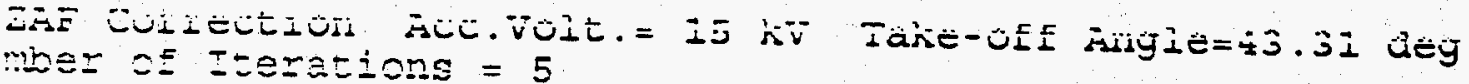

\begin{tabular}{|c|c|c|c|c|c|c|}
\hline 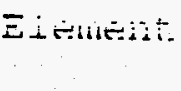 & 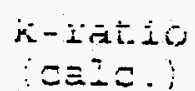 & $\overline{L A} \bar{F}$ & jitoni & Ejement & Wt & ivo. of \\
\hline$\because x-7$ & 0.0032 & 2718 & I. 04 & & Sigmz & ヨtions \\
\hline$\ddot{m}=\ddot{n}$ & 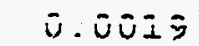 & エ.ラั̄ & $\bar{U} . \dot{i} \bar{i}$ & $\begin{array}{l}0.87 \\
\bar{v} .37\end{array}$ & 0.15 & 0.400 \\
\hline$\therefore-Z$ & 0.0141 & 1.529 & 2.32 & $\begin{array}{l}\overline{0.37} \\
2.29\end{array}$ & $\bar{u} \cdot \bar{\cup}$ & U. Iñ \\
\hline$=\dot{i}-\ddot{r}$ & $\because 0205$ & 1.567 & 2.77 & $\begin{array}{l}2.29 \\
2 \cdot 85\end{array}$ & 0.08 & 0.895 \\
\hline $\bar{z}-\bar{r}$ & บิงธูง & i.275 & $\bar{~}$ & $\begin{array}{l}2.85 \\
\text { i. } 01\end{array}$ & 0.08 & 1.072 \\
\hline$\Xi-Z$ & $\approx .0 \geq \leq 0$ & 1.151 & 1.56 & $\begin{array}{l}\bar{v} . \overline{1} \\
2.94\end{array}$ & $+i-\bar{U} . \bar{U} \bar{\Delta}$ & ט. บิธ̄ \\
\hline$\because-\pi$ & $\therefore 0,070$ & 1.145 & 0.62 & $\frac{1}{0} \cdot 8$ & 0.08 & 0.604 \\
\hline$\because-\pi$ & $\bar{u} . \bar{\cup} 3.3$ & I. ত̄ष் & $\bar{u} . \Sigma \dot{4}$ & 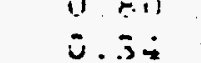 & 0.07 & 0.239 \\
\hline$\because \equiv-\Xi$ & $=.2238$ & 1.018 & 8.50 & $\bar{v} . .3 i$ & $\bar{u} . \bar{u} \bar{T}$ & $\bar{u} . \bar{u} \bar{s}$ \\
\hline$=\approx-\pi$ & -3.3740 & I. 112 & 20.35 & $2=.50$ & 0.28 & 3.324 \\
\hline$\equiv x-\bar{z}$ & $\bar{U} . \bar{U} \tilde{U}$ & I. 277 & & $=i \quad 5 \pi$ & 0.85 & $\begin{array}{ll}7 & 854\end{array}$ \\
\hline$\because \approx-Z$ & 0.0000 & 701 & . u & $\bar{v} \cdot \tilde{u} z$ & $0.2 z$ & ט. טิธี \\
\hline$\therefore \quad-\bar{r}$ & $\therefore j-\overline{1}$ & 2708 & 200 & $=.00$ & 0.00 & 0.000 \\
\hline$\because=こ \bar{\Sigma}$ & & 2100 & $62 \cdot 12$ & $35 \div 1$ & 0.48 & -- \\
\hline & & & טu・uv & -00.00 & & ذ1 \\
\hline
\end{tabular}

The anber of cation resuits are based uon 24 oxven atoms 


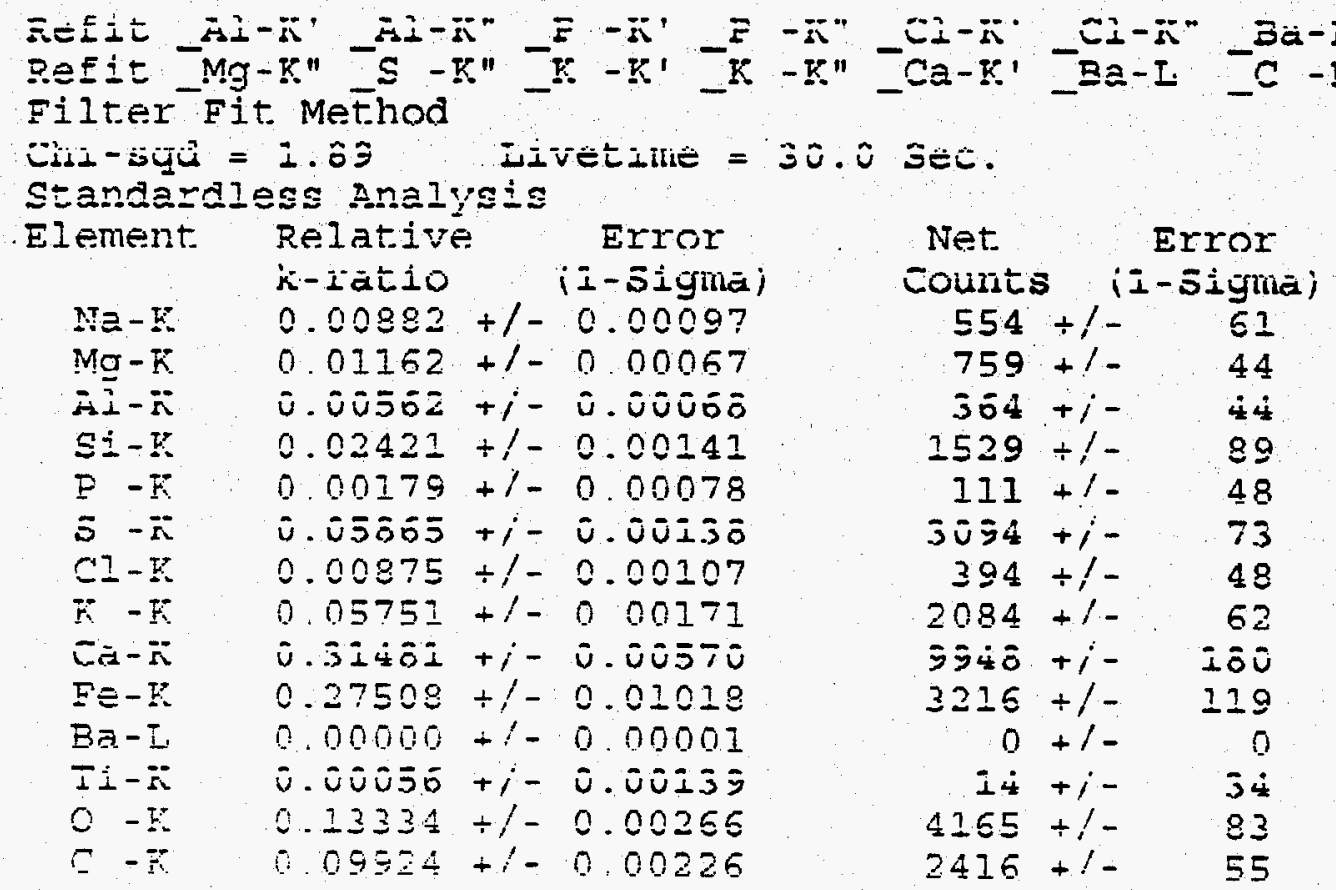

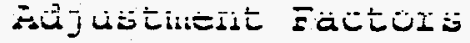
Z-Balance :

She11:

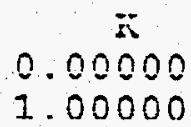

i

0.00000

1.00000 in

0.00000

1.00000

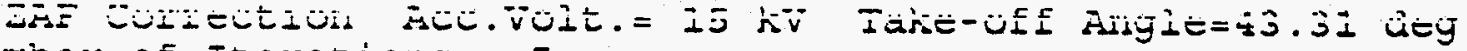
sumine oE IEลrations = 5

\begin{tabular}{|c|c|c|c|c|c|c|}
\hline ËEMULL & 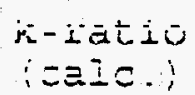 & $\bar{i} \bar{s} \bar{\Sigma}$ & Ftom & 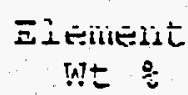 & $\begin{array}{l}\text { (1) } \\
\text { (1-Sigma) }\end{array}$ & $\begin{array}{l}\text { ivo. of } \\
\text { Cations }\end{array}$ \\
\hline$i \overline{0}=\bar{z}$ & 0.5054 & 2.347 & 7.22 & 1.28 & $+1-0.14$ & 0.724 \\
\hline$i=\vec{r}$ & $\bar{u} . \bar{U} \bar{U}$ & エ.755 & I.j4 & $=2 . \overline{0}$ & $+i-\bar{u} . \bar{U} \bar{T}$ & $\overline{\mathrm{u}} \cdot \overline{\mathrm{B}} \overline{\mathrm{s}}$ \\
\hline$\therefore \bar{I}-z$ & 0.0035 & 1.511 & 0.43 & 0.52 & 0.05 & 0.253 \\
\hline$=i-\overline{1}$ & $\therefore 0150$ & 1282 & 150 & 1.9? & $+1-0.11$ & 0.839 \\
\hline $\bar{E}-\bar{x}$ & ง. บิ๋ & 1.225 & $\bar{u} . \overline{\mathbf{u}}$ & $\bar{u} . \dot{I} \dot{q}$ & 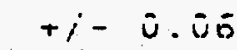 & $\bar{u} . \bar{\cup} \bar{t}$ \\
\hline$\Xi-\Sigma$ & 2.0362 & 1.118 & 2.78 & 4.05 & $+1-0.20$ & 1.615 \\
\hline$\because-\bar{Z}$ & $\therefore \quad-554$ & 1.139 & 0.38 & 1) $5=$ & 0.07 & 0.226 \\
\hline$\because-\ddot{Z}$ & 人. & エ.ンラこ & 2.10 & .3 .74 & $+i-\bar{u} . I I$ & I. $2 \dot{4} \dot{4}$ \\
\hline 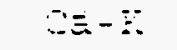 & 0.1941 & 1.056 & 11.29 & 20.54 & $+1-0.37$ & 6.672 \\
\hline $\bar{F}=-\bar{Y}$ & $\therefore .1699$ & 1.156 & 7.74 & I9 65 & $+1-073$ & 4.582 \\
\hline$\equiv x-i$ & 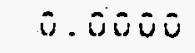 & I. 350 & $\bar{U} . \bar{U}$ & $\dot{u} . \bar{u} \bar{u}$ & $+i-\bar{u} \cdot \bar{u} \bar{u}$ & $\bar{u} . \bar{v} \bar{s}$ \\
\hline$\because=-Z$ & 2.0003 & 2.275 & 0.02 & 2.04 & $+1-0.10$ & 0.011 \\
\hline 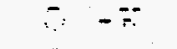 & $5 \quad 5=$ & 3.580 & $40 \equiv 6$ & 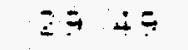 & $+1-0 \equiv 9$ & $\cdots$ \\
\hline $\begin{array}{l}=-\pi \\
=ஃ こ\end{array}$ & D. & 2.730 & $\begin{aligned} & 30 . \overline{4} \\
&=00.00\end{aligned}$ & $\begin{aligned} & 10.77 \\
& 200.00\end{aligned}$ & $\bar{u} . \bar{s}$ & $\begin{array}{l}1 \overline{0} .18 \overline{1} \\
25.255\end{array}$ \\
\hline
\end{tabular}

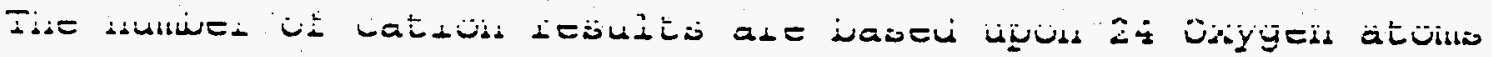




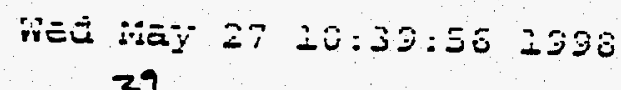

$980 \div 29.1 .4$

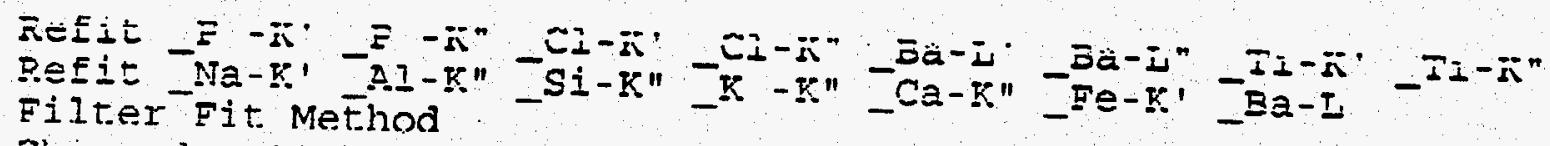

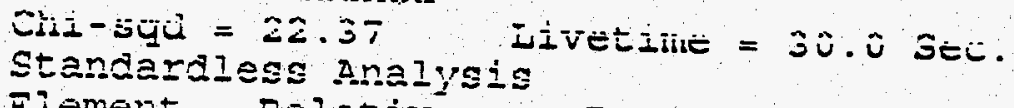

Eiement Relative

\begin{tabular}{|c|c|c|}
\hline & x-ratio & iI-sigma \\
\hline$N=-Z$ & 0.00695 & $+1-0.00114$ \\
\hline$M \underline{I}-\pi$ & 0.01223 & 0.00182 \\
\hline $\bar{i}-\bar{n}$ & טิ. บธธธีธ2 & 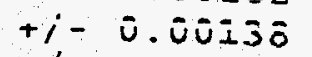 \\
\hline$i-I$ & 0.09544 & 0.00155 \\
\hline$-F$ & 0.00249 & 0.00096 \\
\hline$-\pi$ & $\bar{u} \cdot \bar{v} \overline{4} \dot{4} \dot{z}$ & ט. ৩Uะラठ \\
\hline$-F$ & 0.01243 & 0.00232 \\
\hline$-F$ & 0.04731 & 0.00194 \\
\hline$a-\pi$ & ט. .รธธธらі & $+i-\quad \bar{u} \bar{v} \dot{4} \overline{0}$ \\
\hline$=-Y$ & 0.13870 & $\div /-0.01050$ \\
\hline$-I$ & 0.00000 & $+1-0.00001$ \\
\hline$-\bar{x}$ & $\bar{u} . \overline{0} \pm \overline{ \pm} 5$ & $\bar{u} . \bar{U} \bar{I} \bar{\delta} \bar{\sigma}$ \\
\hline$-\mathrm{E}$ & 0.15985 & $t /-0.00344$ \\
\hline
\end{tabular}

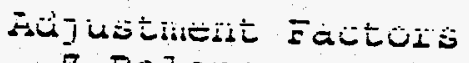

Z-Balance:

Sh:11:

$\pi$
0.00000
1.00000

Net

Counts
$317+1-{ }_{5}^{(i-5 i g m a)}$
52

$580+1-\quad 86$

$25.34+i-\quad \overline{5}$

$4420+/-\quad 71$

$111+1-\quad 43$

$323 I+i-$ i2i

$407+/-\quad 43$

$1243+1-\quad 51$

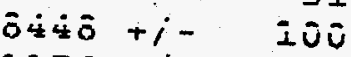

$1176+/-\quad 89$

$0+1-\quad 0$

$76+i-\quad 31$

$3850+1-78$

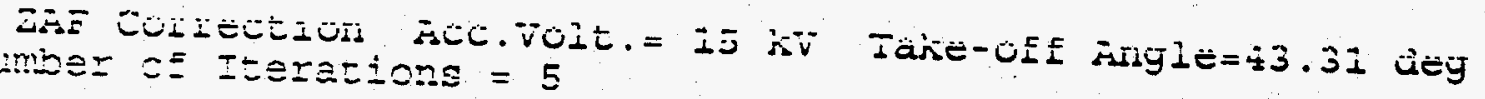

\begin{tabular}{|c|c|c|c|c|c|c|}
\hline 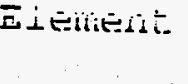 & 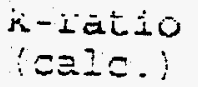 & $\overline{Z A} \bar{F}$ & Ätom: & ÈEnient & $\because \overline{0} \bar{x}$ & ivo. of \\
\hline$M a-7$ & o nnis & 2160 & 1.04 & Tt & Sigma) & Cətions \\
\hline$i v i y-r$ & ט. & 1. $\overline{53} \overline{5}$ & $\begin{array}{l}1.04 \\
1.32\end{array}$ & 0.97 & -016 & 0.431 \\
\hline$\therefore \bar{I}-E$ & 0.0363 & 1.435 & $\begin{array}{l}1.31 \\
4.74\end{array}$ & $\begin{array}{l}1.30 \\
5\end{array}$ & $\bar{u} \cdot I \bar{s}$ & $\bar{U} .5 \dot{4} \dot{4}$ \\
\hline$=i-F$ & 00623 & 1.279 & 5.98 & $\begin{array}{l}5.20 \\
7.97\end{array}$ & 0.23 & 1.969 \\
\hline$F-\bar{z}$ & 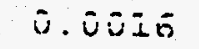 & 1.272 & $\bar{u}$ iñ & $\begin{array}{l}7.97 \\
-\quad=-1\end{array}$ & $+1-0.13$ & 2.897 \\
\hline$\Xi-\because$ & 2.0546 & 1.250 & 4.81 & $\begin{array}{l}\bar{u} \cdot 2 \bar{U} \\
\epsilon .27\end{array}$ & $+i-\bar{u} \cdot \bar{v} \bar{\sigma}$ & 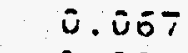 \\
\hline$\because-7$ & $\therefore \quad \therefore 500$ & 1.175 & 0.65 & $\begin{array}{l}5.27 \\
9 i\end{array}$ & $\div \prime-0.22$ & 1.998 \\
\hline 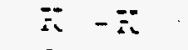 & 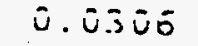 & I. & $\bar{z} . \overline{0} \bar{~}$ & $\begin{array}{l}11 \\
7=-94\end{array}$ & +-0.10 & 0.272 \\
\hline 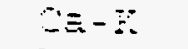 & 0.2382 & 1.070 & 15.65 & $\begin{array}{r}3.25 \\
250 \\
5 n\end{array}$ & $+i-\bar{u} . \bar{I} . \bar{z}$ & $\bar{v} . \overline{8} \overline{4}$ \\
\hline$==-\because$ & $\therefore \quad \therefore 556$ & 1.159 & 458 & 25.50 & $+1-0.30$ & 5.493 \\
\hline$\Xi a-Z$ & 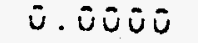 & エ.ふララ & $\dot{u} . \bar{u} \bar{u}$ & 10.39 & +-0.79 & 1.599 \\
\hline$\because Z$ & 0.0029 & 1.199 & 0.18 & 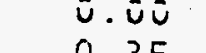 & $+i-\bar{u} . \bar{v} \bar{v}$ & บิ.บับับ \\
\hline$\therefore-\pi$ & $\therefore \quad \therefore=5$ & 3. 427 & 5783 & 2.35 & 0.14 & 0.075 \\
\hline 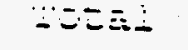 & & & 200.80 & 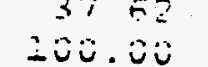 & 075 & $\cdots$ \\
\hline
\end{tabular}

The muber of cation results are based hoon 24 oxygen atoms 


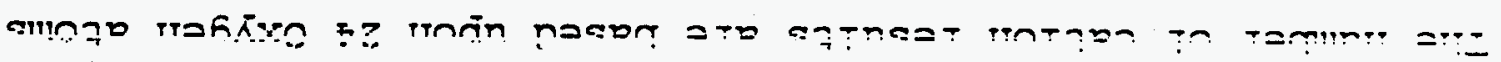

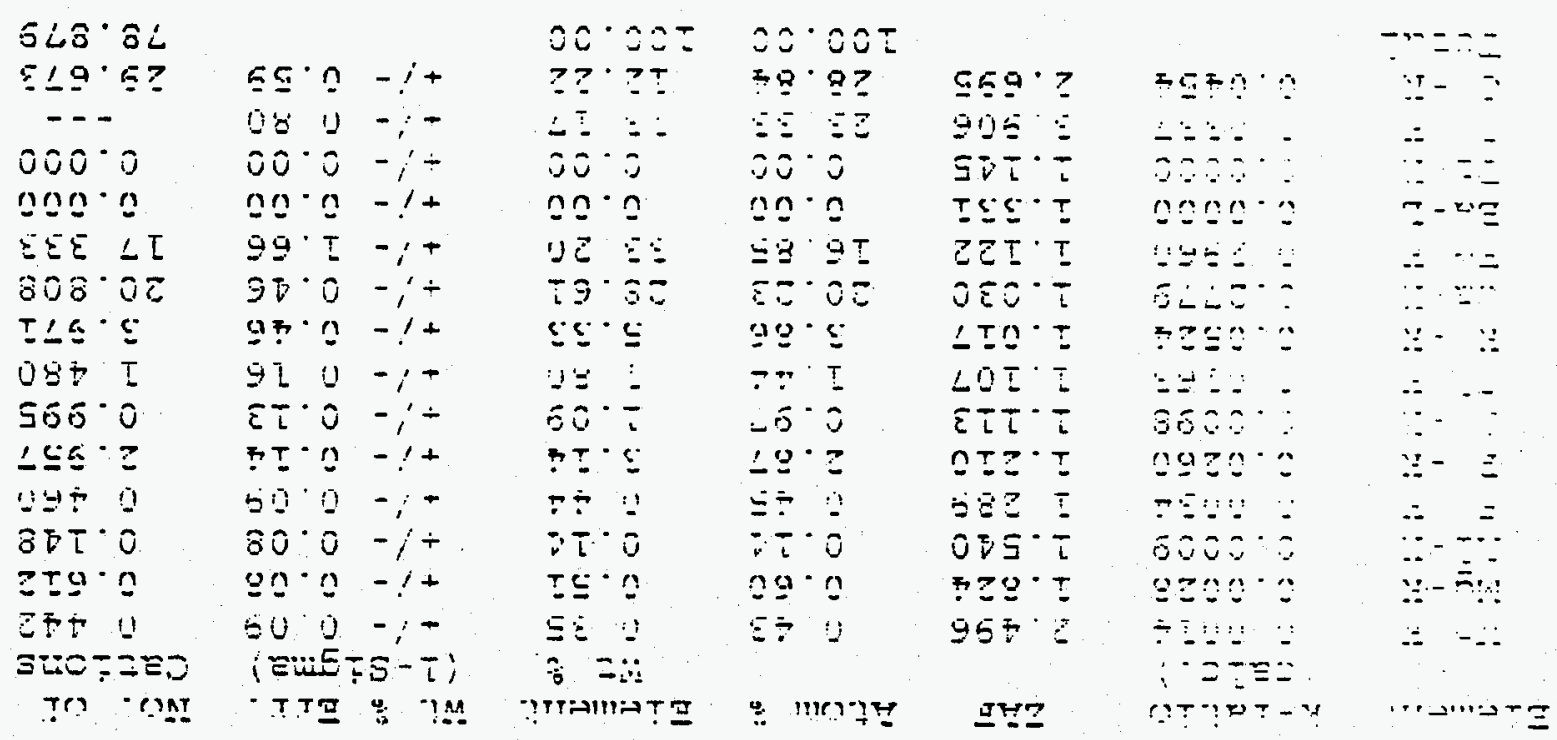

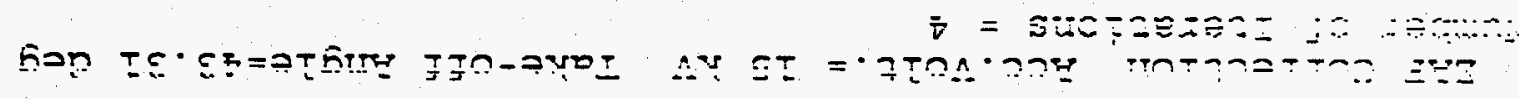

\begin{tabular}{|c|c|c|c|}
\hline $\begin{array}{l}00000 \cdot \tau \\
\text { nnañ. }\end{array}$ & 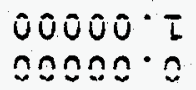 & 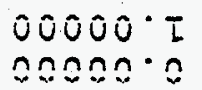 & 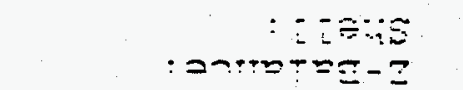 \\
\hline is & $\bar{I}$ & $I$ & 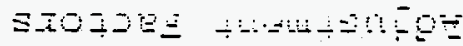 \\
\hline
\end{tabular}

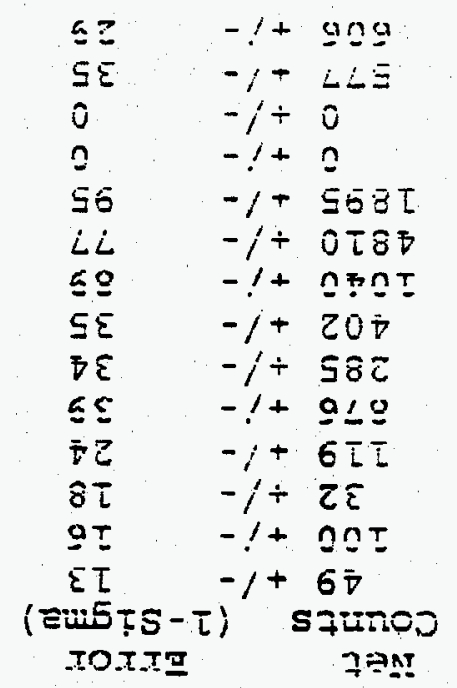

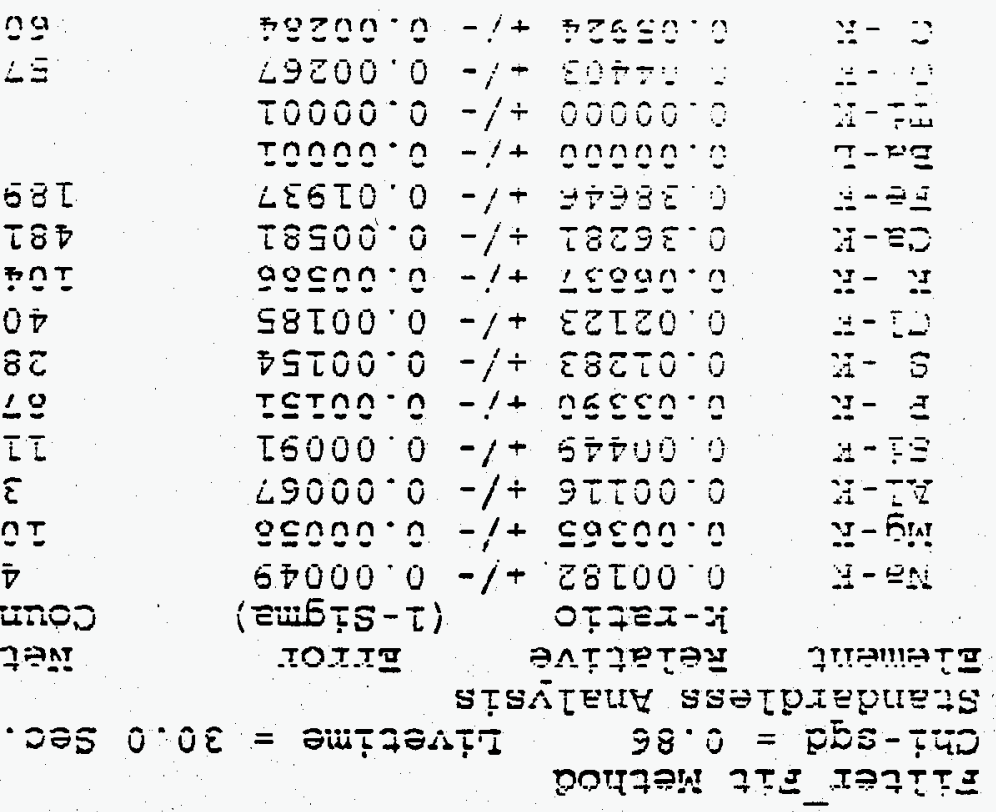

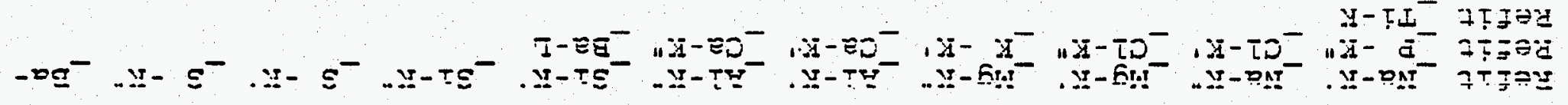


580429.2 .3

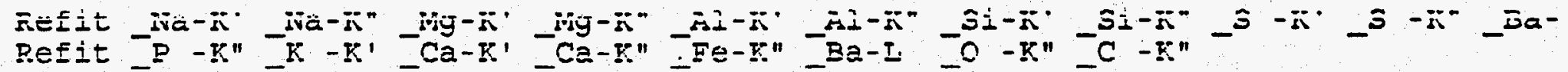
Filter Fit Method Lhi-squ $=0.57$ Iivetime $=30.0$ sec. Standardiess analysis

Element:

\section{Relative Error}

$\mathrm{NT}-\mathrm{T}$

$\mathrm{Mg}-\mathrm{F}$

$\bar{A} \bar{i}-\bar{s}$

$S i-K$

F $-F$

$s-\pi$

$C I-Y$

Fi $-\mathrm{K}$

$\overline{c a-r a}$

Fe-K

Ea-i

$\bar{i}+\bar{L}$

$0 .-F$

$-7$ ri-iatio (i-Sigmia)

$0.00453+1-0.00068$

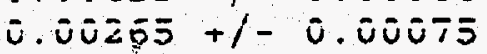

$0.00756+1-0.00099$

$0.05367+1-0.00170$

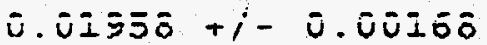

$0.03326 \div 1-0.00350$

$0.10626+i-0.00577$

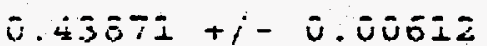

$0.14924 \div /-0.00894$

0. $00000+1-0.00001$

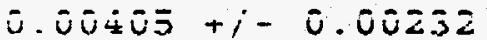

$0.05919+1-0.00192$

c. II665+1-0.00256

\begin{tabular}{|c|c|c|}
\hline Net. & & Error \\
\hline Count: & & i-sigma \\
\hline 132 & $+1-$ & 17 \\
\hline 134 & $+1-$ & 20 \\
\hline 73 & $+i-$ & 22 \\
\hline 215 & $\div 1-$ & 28 \\
\hline 1486 & $+1-$ & 47 \\
\hline $4 \overline{0}$ & $+i-$ & $\dot{4} \bar{v}$ \\
\hline 675 & $\div /-$ & 71 \\
\hline 1732 & $+1-$ & 94 \\
\hline 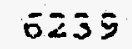 & $+i-$ & 67 \\
\hline 786 & $+1-$ & 47 \\
\hline 0 & $+1-$ & 0 \\
\hline $4 \bar{z}$ & $+i-$ & 24 \\
\hline 832 & $+1-$ & 27 \\
\hline 1278 & $+1-$ & 28 \\
\hline
\end{tabular}

iif

0.00000

1.00000

I

0.00000

1.00000

1.00000

$\square-E \Xi Z \Xi \because: \approx \cong:$

0.00000

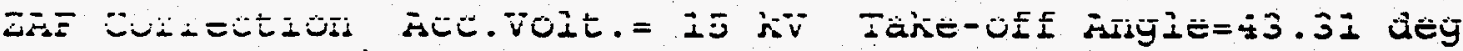

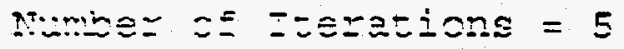

\begin{tabular}{|c|c|c|c|c|c|c|}
\hline ELtutü. & 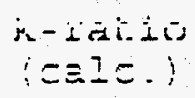 & $\overline{L A} \bar{F}$ & Aton: & 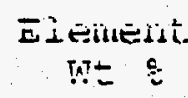 & 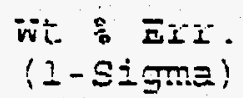 & $\begin{array}{l}\text { ivio. of } \\
\text { Cations }\end{array}$ \\
\hline$\overline{n_{3}}-\bar{Y}$ & $\therefore A 0=$ & 2.181 & 650 & 567 & $\because-7 \pi$ & 058 \\
\hline$\ddot{z}=$ & 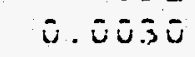 & $1 . \overline{04} 7$ & $\bar{\omega} .4 \overline{0}$ & $\bar{u} . \dot{4} \bar{y}$ & $+i-\bar{u} . \bar{u}$ & ธ. $\dot{\Psi} \bar{\cup}$ \\
\hline$\therefore-\because$ & 2.0028 & 1.429 & 0.21 & 0.25 & 0.07 & 0.185 \\
\hline$=\because-\because$ & r. 0050 & 1.225 & 050 & i. $6 I$ & $+1-0 \cap 8$ & ก 436 \\
\hline$\equiv-\ddot{z}$ & 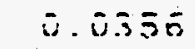 & ェニ75 & $\overline{3} . \overline{0}$ & $\dot{4} . \dot{\bar{s}}$ & $\bar{u} . \bar{I}$ & 2. \\
\hline $2-\because$ & 2.0230 & 1.103 & 2.02 & 2.43 & 0.12 & 0.891 \\
\hline$-\bar{r}-\bar{r}$ & $\therefore \quad 022 i$ & 1.109 & $i \equiv 7$ & $=45$ & $+i-0.26$ & 1.375 \\
\hline$\because-z$ & シ.ジラン & I. v.ji & $\dot{4} .2 .3$ & テ.こラ & $\bar{u} . \dot{\varphi} \bar{u}$ & $3.72 z$ \\
\hline$C \equiv-\Xi$ & 0.2921 & 1.056 & 17.56 & $32.0 \therefore$ & 0.43 & 25.424 \\
\hline$=-\pi$ & $\therefore \quad 1550$ & I. 164 & 4.58 & $I I \equiv 3$ & 0 fG & 4.112 \\
\hline$\equiv=-$ & 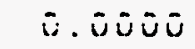 & I. $\dot{4}$ I & $\bar{u} . \bar{u} \bar{u}$ & $\bar{u} . \bar{u}$ & $\bar{u} . \bar{u}$ & ט. บิธีบ \\
\hline$\because \therefore-5$ & $\approx .0027$ & 1.211 & 0.15 & 0.33 & $\div 1-0.29$ & 0.135 \\
\hline$\therefore \quad-7$ & $\therefore \quad \therefore \Xi \Xi$ & $\because 910$ & 275 & $\Xi G \quad \check{r}$. & $\therefore-G \in 2$ & -- \\
\hline$=-\pi$ & $\bar{\theta}$ 酒任 & 2.540 & 35.57 & 20.4 & $+i-\bar{u} . \dot{4} \bar{y}$ & $3 \overline{3} . \overline{7}$ \\
\hline Zニニシ & & & 200.00 & $\approx \approx 0.00$ & & $\in 3$ \\
\hline
\end{tabular}

Fis 


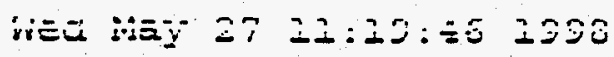

$980 \div 29.3 .1$

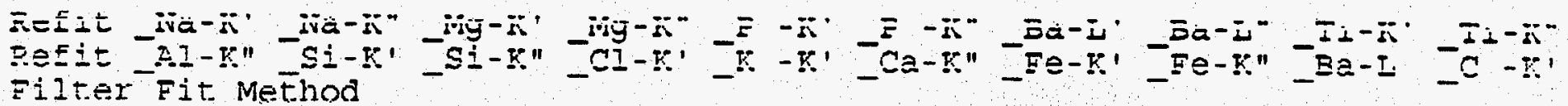

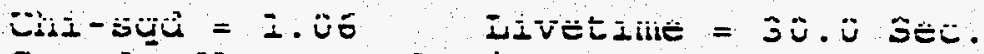

Standardless RnaIYais

\begin{tabular}{|c|c|c|c|c|c|}
\hline Eiement & $\begin{array}{l}\text { Relative } \\
\text { n-iatio }\end{array}$ & $=\begin{array}{c}\text { Error } \\
\text { iI-sigma; }\end{array}$ & $\begin{array}{l}\text { Net } \\
\text { Sounts }\end{array}$ & & $\begin{array}{l}\text { Error } \\
\text {-5ioma }\end{array}$ \\
\hline$N \Xi-F$ & 0.00291 & $+1-0.00059$ & 129 & $+1-$ & 26 \\
\hline$M g-F$ & 0.00622 & $+1-0.00074$ & 288 & $+1-$ & 34 \\
\hline $\bar{i} \bar{i}-\bar{r}$ & 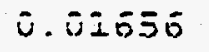 & บ. บิบับิธริว & 750 & $+i-$ & 30 \\
\hline$\cong \pm-F$ & 0.01503 & $+1-0.00087$ & 671 & $\div 1-$ & 39 \\
\hline$P-E$ & 0.00074 & $+1-0.00087$ & 32 & $+1-$ & 38 \\
\hline $\bar{s}-\pi$ & 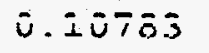 & $+i-$ v. vิūjii & ๕ン்こ̃ & $+i-$ & Iis \\
\hline$C I-Z$ & 0.02206 & $+1-0.00261$ & 702 & $+1-$ & 83 \\
\hline$F-E$ & 0.06218 & $+1-0.00367$ & 1593 & $+1-$ & 94 \\
\hline$\overline{E a}-\pi$ & $\bar{U} .2 \overline{5.3} \overline{2}$ & 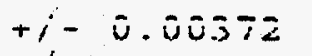 & ラธテら & $+i-$ & 8.5 \\
\hline$E \in-E$ & 0.09001 & $+1-0.00520$ & 818 & $\div 1-$ & 43 \\
\hline$E \Xi-\bar{E}$ & 000000 & $+1-0.00001$ & 0 & $+1-$ & 0 \\
\hline $\bar{i}-\ddot{r}$ & コ.テうふるこ & 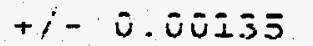 & 5.3 & $+i-$ & $2 z$ \\
\hline$O-F$ & 0.25390 & $\div /-0.00412$ & 5505 & $+1-$ & 91 \\
\hline $5-5$ & 9. 3574 & $+/-0.00331$ & 2525 & $+1-$ & 57 \\
\hline
\end{tabular}

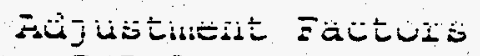

z-Eaュanae:

Sheil:

$\begin{array}{ccc}\pi & i & 10 \\ 0.00000 & 0.00000 & 0.00000 \\ 1.00000 & 1.00000 & 1.00000\end{array}$

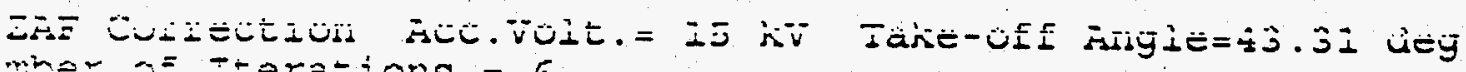

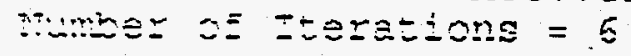

\begin{tabular}{|c|c|c|c|c|c|c|}
\hline 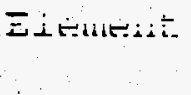 & 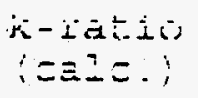 & $\bar{\Sigma} \overline{\bar{I}}$ & Atou & 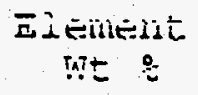 & $(1-5 i \operatorname{sm})$ & $\begin{array}{l}\text { ivo. if } \\
\text { cミtians }\end{array}$ \\
\hline 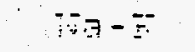 & 00015 & 2. 174 & 0.26 & 0.22 & $\because-0.77$ & 0.121 \\
\hline$i v_{y} y-z$ & $\overline{4} . \overline{6.32}$ & I. 5.55 & ט..ji & 5.52 & 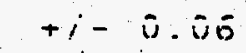 & $\bar{u} . \bar{\alpha} \bar{s}$ \\
\hline$\therefore \bar{Z}-\bar{Z}$ & 0.0094 & 1.431 & 0.83 & 2.21 & $+1-0.05$ & 0.397 \\
\hline$\Xi \div-\vdots$ & $\therefore 5077$ & I. 244 & 0.63 & $\therefore \quad 95$ & $\therefore-0.5$ & ㄱ. 294 \\
\hline $\bar{E}-\bar{r}$ & ล. ลธ่ง & エ.シララ & $\bar{v} . \bar{v} \bar{s}$ & $\bar{u} \cdot \overline{4}$ & $+i-\bar{u} \cdot \bar{s}$ & $\bar{u} . \bar{u} \bar{j}$ \\
\hline 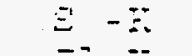 & 2.0550 & 1.107 & 3.50 & 6.09 & $+\because-0.18$ & 1.643 \\
\hline 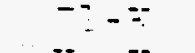 & 9.913 & 1.154 & 0.68 & $=3 \pi$ & $\because-0$ i5 & 9. 317 \\
\hline$\because-r$ & $\therefore .8 .37$ & I. $\bar{v} \overline{4}$ & I. $5 z$ & $.2 .4 \dot{4}$ & $+i-\bar{u} .2 \bar{u}$ & $\bar{U} .7 \bar{\Delta}$ \\
\hline$\because=-\vdots$ & $\therefore-3 \pm 2$ & 2.084 & $5 . \subseteq 9$ & 12.51 & $0.2 I$ & 3.236 \\
\hline $\bar{z}=-\bar{r}$ & $\because 505$ & 1.187 & 1. 98 & $=55$ & $+1-032$ & ก. 928 \\
\hline$E_{a}=-i$ & 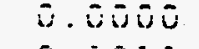 & I. $4 \overline{\mathrm{s}} \overline{\mathrm{s}}$ & $\bar{u} \cdot \bar{u} \bar{u}$ & $\bar{u} . \bar{v} \bar{u}$ & $+i-\bar{v} \bar{u}$ & 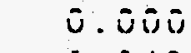 \\
\hline 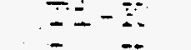 & $\because 201$ & $=202$ & 0.09 & $\therefore .23$ & $\div:-0.08$ & 0.0 .12 \\
\hline$\because \quad-\because$ & $\because \quad \overline{1}=5$ & 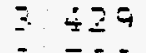 & 51.77 & $-4 \div$ & 072 & -- \\
\hline $\begin{array}{l}-4 \\
-3=3\end{array}$ & $\dot{0} .075$ & $2.75 \overline{5}$ & $\begin{aligned} 3 \overline{2} .14 \\
=00.00\end{aligned}$ & 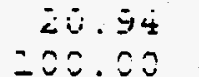 & $+j-\bar{\nu} \cdot \dot{i}$ & 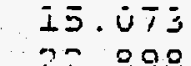 \\
\hline
\end{tabular}

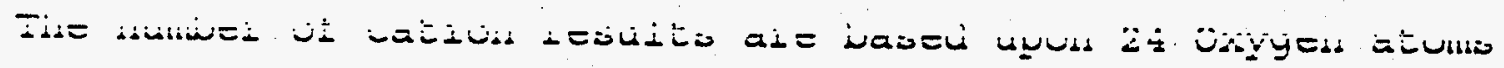




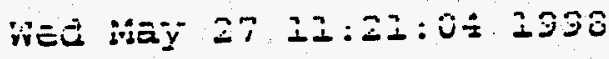

980429.3 .2

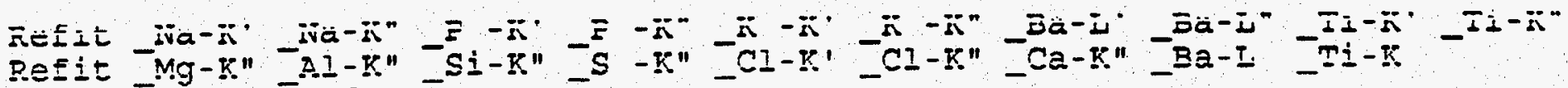
Filter Fit Method

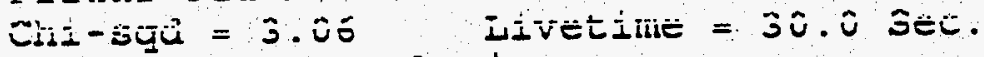
Standardless dnalysis

Element.

\section{Relative}

x-Iatio

$N a-F$

$M Q-F$

$0.00236+1-$

ii-sigma;

$\bar{A}-\bar{n}$

$0.01653+1-0.00074$

$S i-\mathrm{R}$

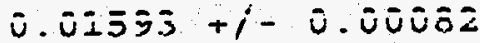

$P-K$

$0.02953+1-0.00094$

$\bar{s}-\pi$

$0.00082+1-0.00074$

Cl-Y

บ. $02.33 I+i-$

ง. บบธฐป4

K $-\mathrm{r}$

0.01157

$+1-$

0.00107

$\overline{c a}-\bar{r}$

0.00585

$+1-$

บ. 2 ¿55T+1-

0.00105

Fəー

$0.37490+1-$

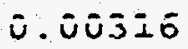

Ba-I.

0.00000

$1-$

0.01201

$\bar{I}+\bar{r}$

O. $-\underline{K}$

$0.22257+1-$

0.00001

$-F$

$0.07657+1-0.00268$

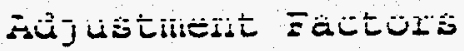

Z-Balance:

Shel1:

$\pi$
0.00000
1.00000

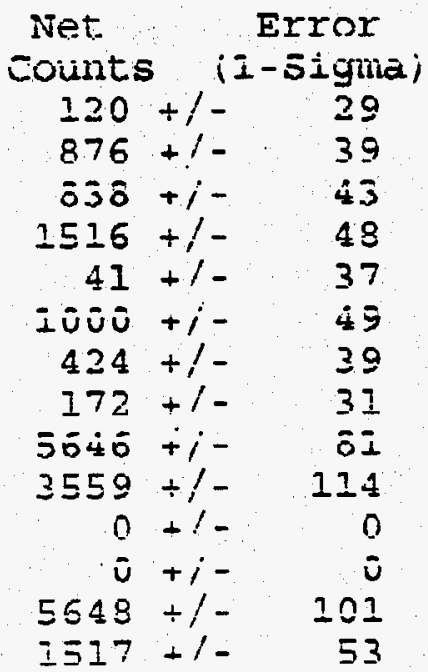

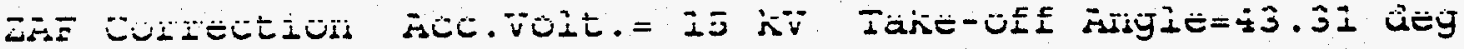
Mumior OE Iterations = 5

\begin{tabular}{|c|c|c|c|c|c|c|}
\hline 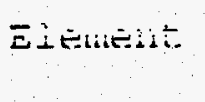 & 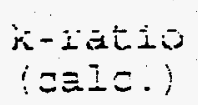 & $\bar{Z} \bar{A} \bar{\Sigma}$ & Aंtom ? & $\begin{array}{c}\text { EIEHEHE } \\
\text { Wt ? }\end{array}$ & 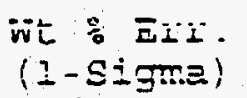 & $\begin{array}{l}\text { ivio. of } \\
\text { cations }\end{array}$ \\
\hline$M A-F$ & 0.0015 & 2.498 & 0.35 & 0.36 & $+1-0.09$ & 0.164 \\
\hline$\therefore y-r$ & ט. Uラン & 1.027 & $1.0 \overline{0}$ & I. & $+i-\bar{u} . \bar{v}$ & $\overline{0} . \overline{5}$ \\
\hline$x \bar{z}-y$ & 0.0098 & 2. 565 & 1.25 & 1.54 & 0.28 & 0.501 \\
\hline 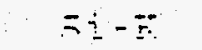 & 0.018 & 1.328 & 1.89 & $\geq 42$ & 0.08 & 0.893 \\
\hline$\equiv-\pi$ & 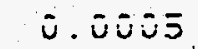 & 1.254 & $\bar{u} . \bar{u} \bar{s}$ & u. v̄ó & $\bar{u} \cdot \bar{v} \bar{c}$ & $\bar{u} \cdot \bar{u} z$ \\
\hline$\Xi-Y$ & $0.0144^{\circ}$ & 1.143 & 1.23 & 2.65 & 0.08 & 0.532 \\
\hline$-i-\bar{r}$ & 0.0672 & 1.146 & 0.51 & 9.2 & $+1-0.08$ & ก. 239 \\
\hline$\because-\ddot{z}$ & $\bar{U} . \bar{u} \bar{u} \bar{s} \overline{0}$ & エ.ンララ & $\bar{U} . \Sigma I$ & 5.36 & $\overline{\bar{u}} \overline{\overline{0}}$ & $\bar{u} . \bar{\imath} \bar{u}$ \\
\hline$\sigma \equiv-\Sigma$ & 0.2359 & 1.041 & 7.74 & 1.14 & 0.20 & 3.653 \\
\hline$=-\bar{r}$ & $\overline{7} 2 \pm 16$ & 1.147 & 10.43 & 25.56 & $+i-085$ & 4.924 \\
\hline $\bar{E} a-\bar{z}$ & 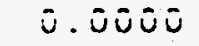 & I.3I0 & $\bar{v} . \bar{v} \bar{u}$ & $\bar{u} . \bar{u} \hat{u}$ & $\bar{u} . \bar{u} \dot{u}$ & $\bar{v} . \bar{v} \bar{u}$ \\
\hline$\Xi \pm-E$ & 0.0200 & 7.227 & 0.00 & 2.20 & $+1-0.00$ & 0.000 \\
\hline$\therefore \quad-\because$ & $\therefore \quad 5: 5$ & 2.597 & 5.84 & $\vdots \div \quad \square$ & $+1-066$ & -- \\
\hline $\begin{array}{l}=-\bar{r} \\
=\circlearrowright \Delta\end{array}$ & $\dot{0.647}$ & ¿.テロ̄ & $\begin{array}{r}23 . \overline{3} \\
103.00\end{array}$ & $\begin{aligned} & 13 . i 0 \\
= & 00.20\end{aligned}$ & $+i-\bar{u} .4 \bar{b}$ & $\begin{array}{l}11.252 \\
23.206\end{array}$ \\
\hline
\end{tabular}

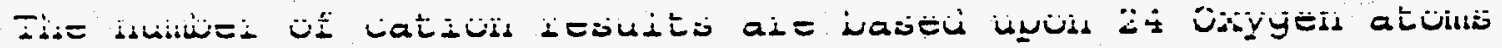


R̈̈丿工乚

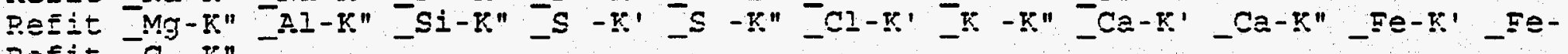
Pefit -C $-K^{n}$

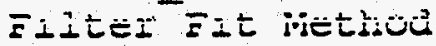
Chi-sqa $=1.05$ Iivetime $=30.0 \mathrm{sec}$.

St.andardless Analvsis

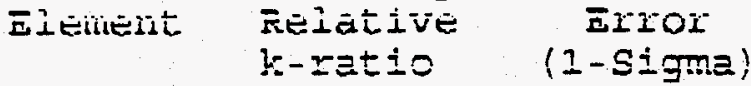

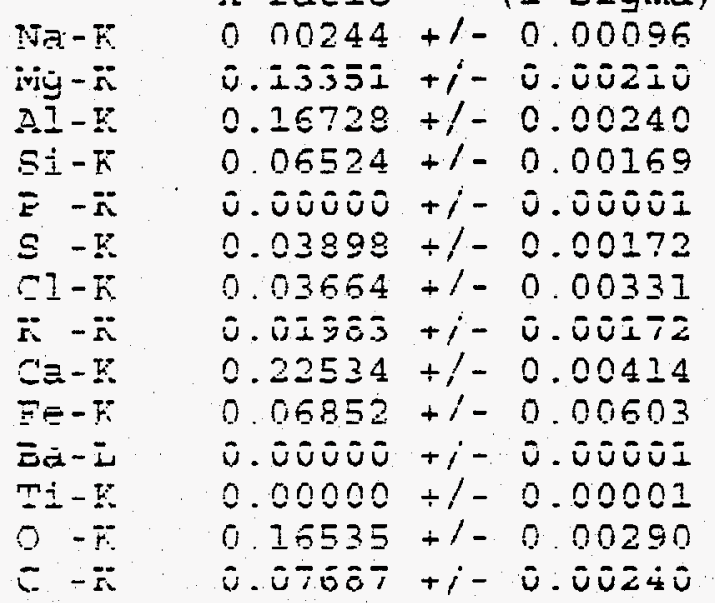

Adustment Factors

¿-Dajance:

SheII:

$\therefore K$

ง. ิงษิงิ์

1.00000

\section{ivet}

Counts (1-sisma)

$76+1-30$

$4.530+i-\quad \overline{0}$

$5379+1-\quad 77$

$2048+1-\quad 53$

$1+i-\quad 5$

$1023 \div /-\quad 45$

$821+1-\quad 74$

$357+i-\quad 3 i$

$3539+1-\quad 65$

$399+1-\quad 35$

i $+i-i$

$0+1-\quad 0$

$2567+1-\quad 45$

$53 \bar{u}+i-2 \overline{3}$

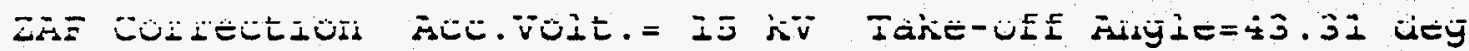
Muiver of Iterations = ?

\begin{tabular}{|c|c|c|c|c|c|c|}
\hline 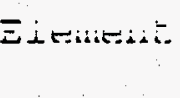 & 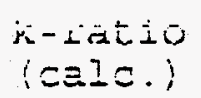 & Z五 & Atoni & $\begin{array}{c}\text { Eientisis } \\
\text { Mt: \& }\end{array}$ & 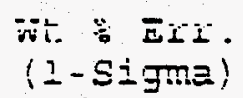 & $\begin{array}{l}\text { ivo. uî } \\
\text { Cations }\end{array}$ \\
\hline $9-7-7$ & 00013 & I. 848 & 021 & 024 & $+1-0.10$ & 0.137 \\
\hline 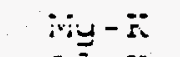 & 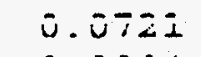 & I. $\dot{4} \dot{4} \bar{\sigma}$ & 5.52 & エบ. $\dot{\Psi} \overline{5}$ & $+i-\bar{u} . i \bar{s}$ & $5.55 \%$ \\
\hline$\therefore-Y$ & 0.0904 & 2.440 & 9.57 & 23.02 & 0.19 & 6.239 \\
\hline$=\because-\because$ & 8.0353 & 1.572 & 341 & $\div 84$ & 013 & 2226 \\
\hline$E-\check{z}$ & 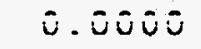 & I.345 & $\bar{v} . \bar{v} \bar{v}$ & $\dot{v} \cdot \bar{v} \bar{v}$ & $+i-\bar{u} . \bar{u}$ & ज. जิธ \\
\hline$\Xi-E$ & 0.2221 & 1.189 & 1.55 & $=.50$ & 0.11 & 2.010 \\
\hline 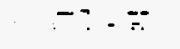 & $\therefore$ †ig & $1: 194$ & 132 & $\Xi \quad 3.5$ & $+1-021$ & (1) S.6. \\
\hline$\because-\because$ & ט. & エ.エบิō & $\bar{v} . \bar{v} \bar{v}$ & i.ij & $+i-j .10$ & $\bar{v} . \bar{j} \bar{s} \bar{s}$ \\
\hline$\therefore \equiv-\because$ & 0.1218 & 1.085 & 5.54 & 12.23 & $\div:-0.24$ & 4.258 \\
\hline$==-F$ & $\therefore \quad 0370$ & 1.175 & 1.54 & $\therefore \quad=$ & $+1-038$ & 7007 \\
\hline$\equiv x-\bar{z}$ & 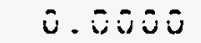 & I. 353.3 & $\bar{u} . \bar{U}$ & ¿. & $+i-\bar{u} . \bar{u}$ & ธ. ธิธี \\
\hline$\because-2-5$ & 2.0000 & 1.297 & 0.20 & 0.00 & 0.00 & 0.000 \\
\hline$\therefore \quad-\because$ & $\div \quad 0.93$ & $3 \quad 324$ & 36.90 & 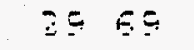 & $-1-1552$ & $\cdots$ \\
\hline $\begin{array}{l}=-\pi \\
=\backsim こ\end{array}$ & $0.04 i 5$ & $\dot{ \pm} .30 \dot{4}$ & $\begin{array}{r}25.52 \\
200.00\end{array}$ & $\begin{array}{r}15 . \overline{13} \\
200.00\end{array}$ & $+i-\bar{u} . \bar{s}$ & $\begin{array}{l}15.514 \\
41.216\end{array}$ \\
\hline
\end{tabular}

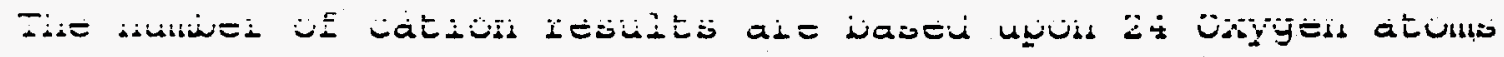


活:

isis H. in

$\rightarrow$

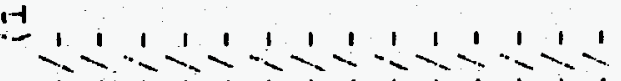

$t+t+t+t+t+t+t+$

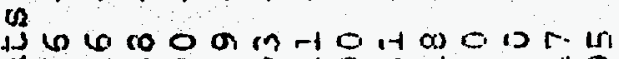

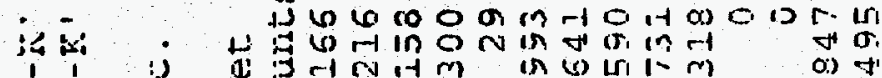

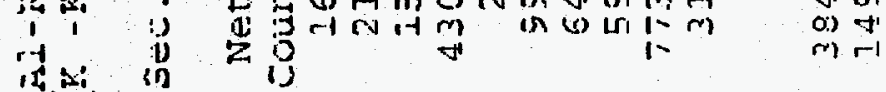
- U H.

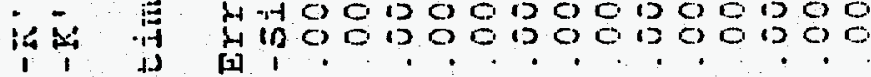

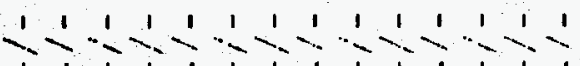
is

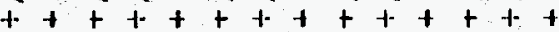
$\log$

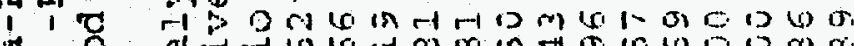

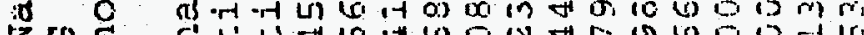

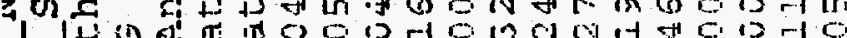

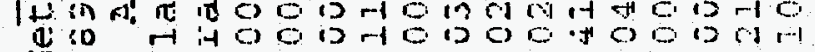
$=\Sigma$ o o d

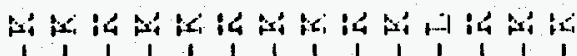
तis

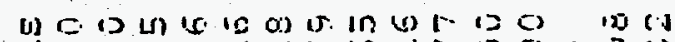

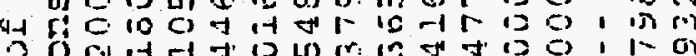

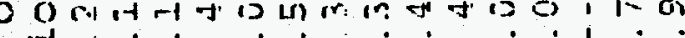

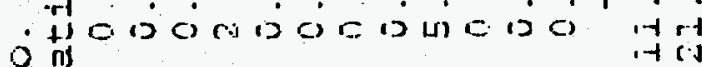
虽罂

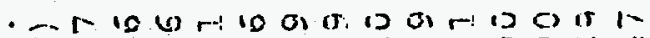

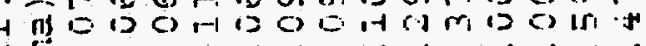

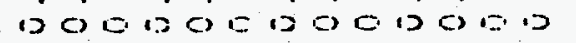
in $01,1,1,1,1,1,1$

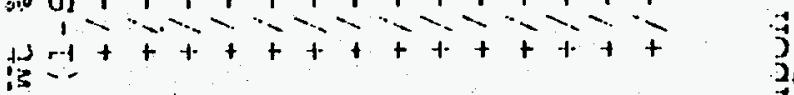

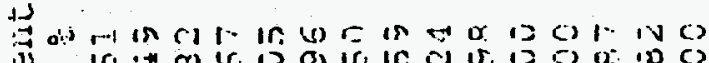

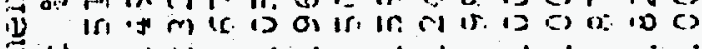

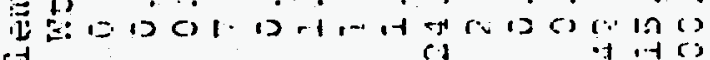
问

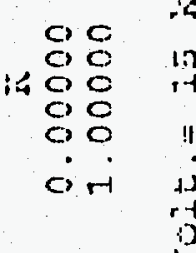

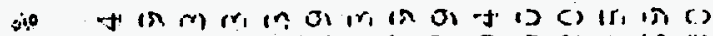

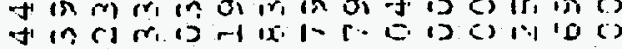
obcin .

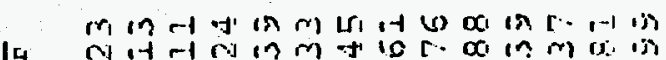

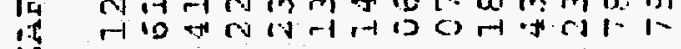

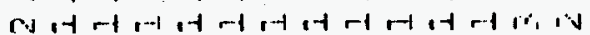

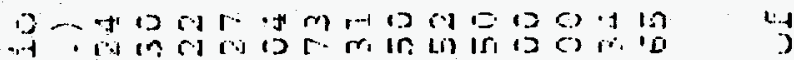
i) d) त

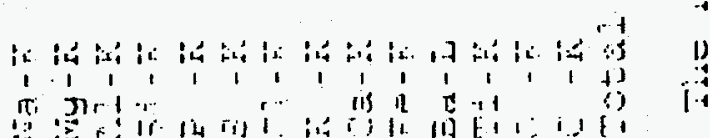


980428.1 .1

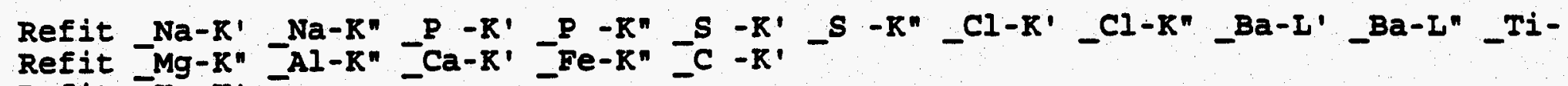

Refit $K-K$ '

Refit $-\mathrm{K}-\mathrm{K}^{\prime}$

Filter Fit Method

Chi-sqd $=1.30 \quad$ Livetime $=30.0 \mathrm{sec}$.

Standardless Analysis

Element Relative Error
k-ratio (1-Sigma)

$\begin{array}{ll}\mathrm{Na}-\mathrm{K} & 0.00269+/-0.00060 \\ \mathrm{Mg}-\mathrm{K} & 0.13706+/-0.00147 \\ \mathrm{~A} I-\mathrm{K} & 0.03574+/-0.00108 \\ \mathrm{~S} I-\mathrm{K} & 0.18181+/-0.00273 \\ \mathrm{P}-\mathrm{K} & 0.00139+/-0.00068 \\ \mathrm{~S}-\mathrm{K} & 0.00271+/-0.00077 \\ \mathrm{Cl}-\mathrm{K} & 0.00959+/-0.00090 \\ \mathrm{~K}-\mathrm{K} & 0.06659+/-0.00164 \\ \mathrm{Ca}-\mathrm{K} & 0.03485+/-0.00311 \\ \mathrm{~F}-\mathrm{K} & 0.08287+/-0.00450 \\ \mathrm{Ba}-\mathrm{I} & 0.00189+/-0.00333 \\ \mathrm{~T} I-\mathrm{K} & 0.00375+/-0.00168 \\ \mathrm{O}-\mathrm{K} & 0.36037+/-0.00379 \\ \mathrm{C}-\mathrm{K} & 0.07870+/-0.00218\end{array}$

Adjustment Factors

z-Balance :

Shell:

$\mathrm{K}$
0.00000
1.00000

$\begin{array}{rr}\text { Net } & \text { Error } \\ \text { Counts } & \text { (1-Sigma) } \\ 170+/- & 38 \\ 9021+/- & 97 \\ 2332+/- & 70 \\ 11575+/- & 174 \\ 87+/- & 42 \\ 145+/- & 41 \\ 436+/- & 41 \\ 2429+/- & 60 \\ 1110+/- & 99 \\ 976+/- & 53 \\ 34+/- & 60 \\ 87+/- & 39 \\ 11423+/- & 120 \\ 1950+/- & 54\end{array}$

ZAF Correction Acc.Volt. $=15 \mathrm{kV}$ Take-off Angle $=44.22 \mathrm{deg}$ Number of Iterations $=7$

\begin{tabular}{|c|c|c|c|c|c|c|}
\hline $\begin{array}{l}\text { Element } \\
\text { Na-K } \\
M g-K \\
A I-K \\
S i-K \\
P-K \\
S-K \\
C l-K \\
K-K \\
C a-K \\
F e-K \\
B a-L \\
T i-K \\
O-K \\
C-K \\
\text { Total }\end{array}$ & $\begin{array}{l}\text { k-ratio } \\
\text { (calc.) } \\
0.0014 \\
0.0718 \\
0.0187 \\
0.0953 \\
0.0007 \\
0.0014 \\
0.0050 \\
0.0349 \\
0.0183 \\
0.0434 \\
0.0010 \\
0.0020 \\
0.1888 \\
0.0412\end{array}$ & $\begin{array}{l}1.945 \\
1.510 \\
1.488 \\
1.305 \\
1.346 \\
1.210 \\
1.201 \\
1.127 \\
1.098 \\
1.181 \\
1.375 \\
1.181 \\
2.417 \\
3.815\end{array}$ & $\begin{array}{r}\text { Atom } \\
0.22 \\
8.20 \\
1.90 \\
8.13 \\
0.06 \\
0.10 \\
0.31 \\
1.85 \\
0.92 \\
1.69 \\
0.02 \\
0.09 \\
52.43 \\
24.08 \\
100.00\end{array}$ & $\begin{array}{r}\text { Element } \\
\text { Wt } t \\
0.27 \\
10.84 \\
2.79 \\
12.43 \\
0.10 \\
0.17 \\
0.60 \\
3.93 \\
2.00 \\
5.13 \\
0.14 \\
0.23 \\
45.63 \\
15.73 \\
100.00\end{array}$ & $\begin{array}{l}\text { wt E Err. } \\
\text { (1-Sigma) } \\
+/-0.06 \\
+/-0.12 \\
+/-0.08 \\
+/-0.19 \\
+/-0.05 \\
+/-0.05 \\
+/-0.06 \\
+/-0.10 \\
+/-0.18 \\
+/-0.28 \\
+/-0.24 \\
+/-0.10 \\
+/-0.48 \\
+/-0.44\end{array}$ & $\begin{array}{l}\text { No. of } \\
\text { Cations } \\
0.100 \\
3.753 \\
0.869 \\
3.723 \\
0.027 \\
0.045 \\
0.143 \\
0.846 \\
0.421 \\
0.773 \\
0.008 \\
0.041 \\
-0- \\
11.022 \\
21.771\end{array}$ \\
\hline
\end{tabular}

The number of cation results are based upon 24 oxygen atoms 
980428.1 .2

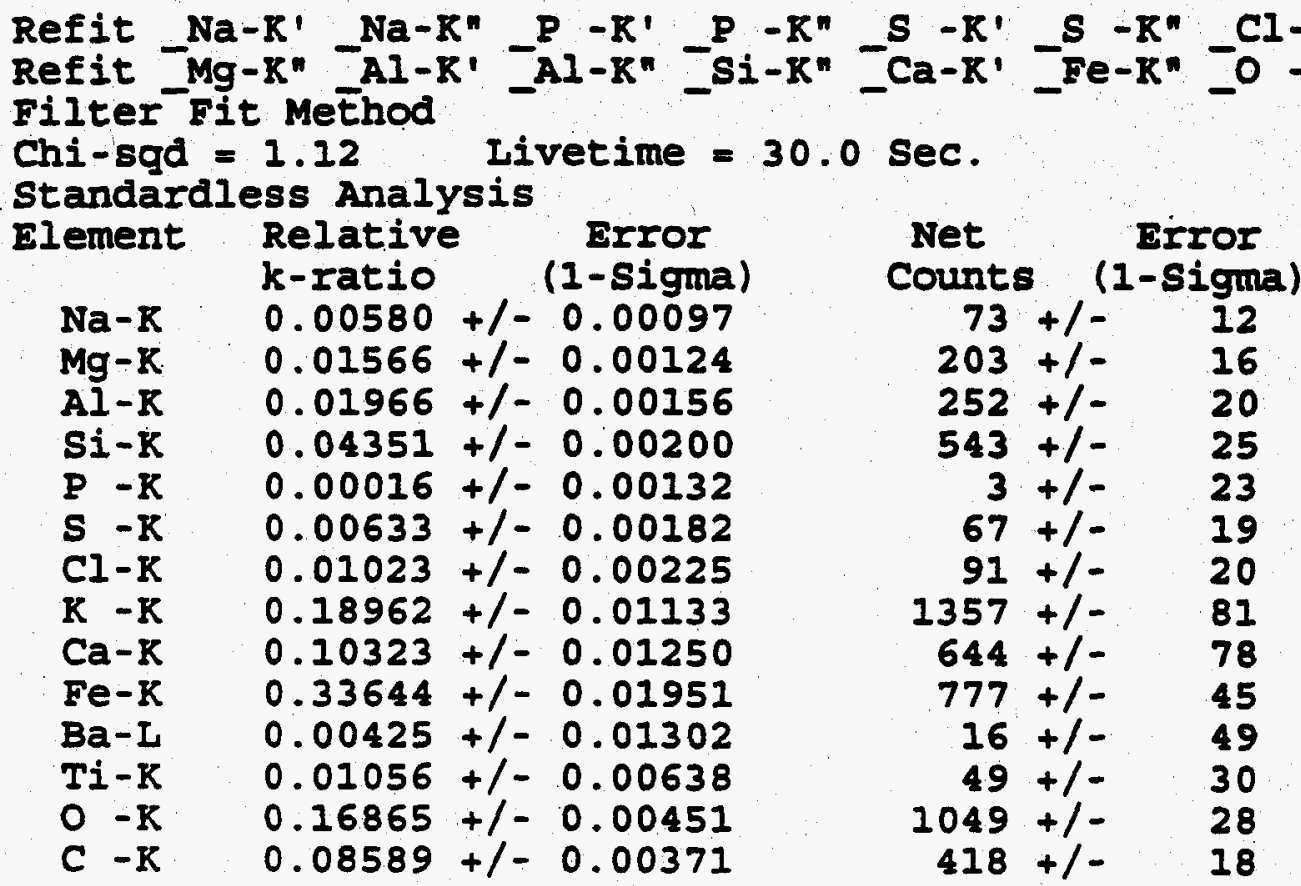

Adjustment Factors

Z-Balance:

Shell:

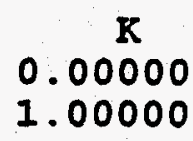

0.00000

0.00000

1.00000

ZAF Correction Acc.Volt. $=15 \mathrm{kV}$ Take-off Angle $=44.22 \mathrm{deg}$ Number of Iterations $=5$

\begin{tabular}{|c|c|c|c|c|c|c|}
\hline $\begin{array}{l}\mathrm{Na}-\mathrm{K} \\
\mathrm{Mg}-\mathrm{K} \\
\mathrm{Al}-\mathrm{K} \\
\mathrm{S} i-\mathrm{K} \\
\mathrm{P}-\mathrm{K} \\
\mathrm{S}-\mathrm{K} \\
\mathrm{Cl}-\mathrm{K} \\
\mathrm{K}-\mathrm{K} \\
\mathrm{Ca}-\mathrm{K} \\
\mathrm{F} e-\mathrm{K} \\
\mathrm{B} \mathrm{a}-\mathrm{L} \\
\mathrm{T} \mathrm{I}-\mathrm{K} \\
O-K \\
\mathrm{C}-\mathrm{K} \\
\text { Total }\end{array}$ & $\begin{array}{l}\text { k-ratio } \\
\text { (calc.) } \\
0.0037 \\
0.0099 \\
0.0124 \\
0.0274 \\
0.0001 \\
0.0040 \\
0.0065 \\
0.1195 \\
0.0651 \\
0.2121 \\
0.0027 \\
0.0067 \\
0.1063 \\
0.0541\end{array}$ & $\begin{array}{l}2.372 \\
1.763 \\
1.522 \\
1.303 \\
1.254 \\
1.132 \\
1.127 \\
1.065 \\
1.071 \\
1.143 \\
1.331 \\
1.144 \\
2.967 \\
2.610\end{array}$ & $\begin{array}{r}0.85 \\
1.61 \\
1.57 \\
2.86 \\
0.01 \\
0.32 \\
0.46 \\
7.33 \\
3.92 \\
9.77 \\
0.06 \\
0.36 \\
44.39 \\
26.49 \\
100.00\end{array}$ & $\begin{array}{r}\text { Element } \\
w t ~ \\
0.87 \\
1.74 \\
1.89 \\
3.57 \\
0.01 \\
0.45 \\
0.73 \\
12.73 \\
6.97 \\
24.24 \\
0.36 \\
0.76 \\
31.54 \\
14.13 \\
100.00\end{array}$ & $\begin{array}{l}\text { Wt Err } \\
\text { (1-Sigma) } \\
+/-0.14 \\
+/-0.14 \\
+/-0.15 \\
+/-0.16 \\
+/-0.10 \\
+/-0.13 \\
+/-0.16 \\
+/-0.76 \\
+/-0.84 \\
+/-1.41 \\
+/-1.09 \\
+/-0.46 \\
+/-0.84 \\
+/-0.61\end{array}$ & $\begin{array}{r}\text { No. of } \\
\text { Cations } \\
0.45 \\
0.87 \\
0.85 \\
1.54 \\
0.005 \\
0.17 \\
0.25 \\
3.96 \\
2.11 \\
5.284 \\
0.032 \\
0.194 \\
14.32 \\
30.068\end{array}$ \\
\hline
\end{tabular}

The number of cation results are based upon 24 oxygen atoms 


\section{Wed May 27 14:48:05 1998}

\section{1 .3}

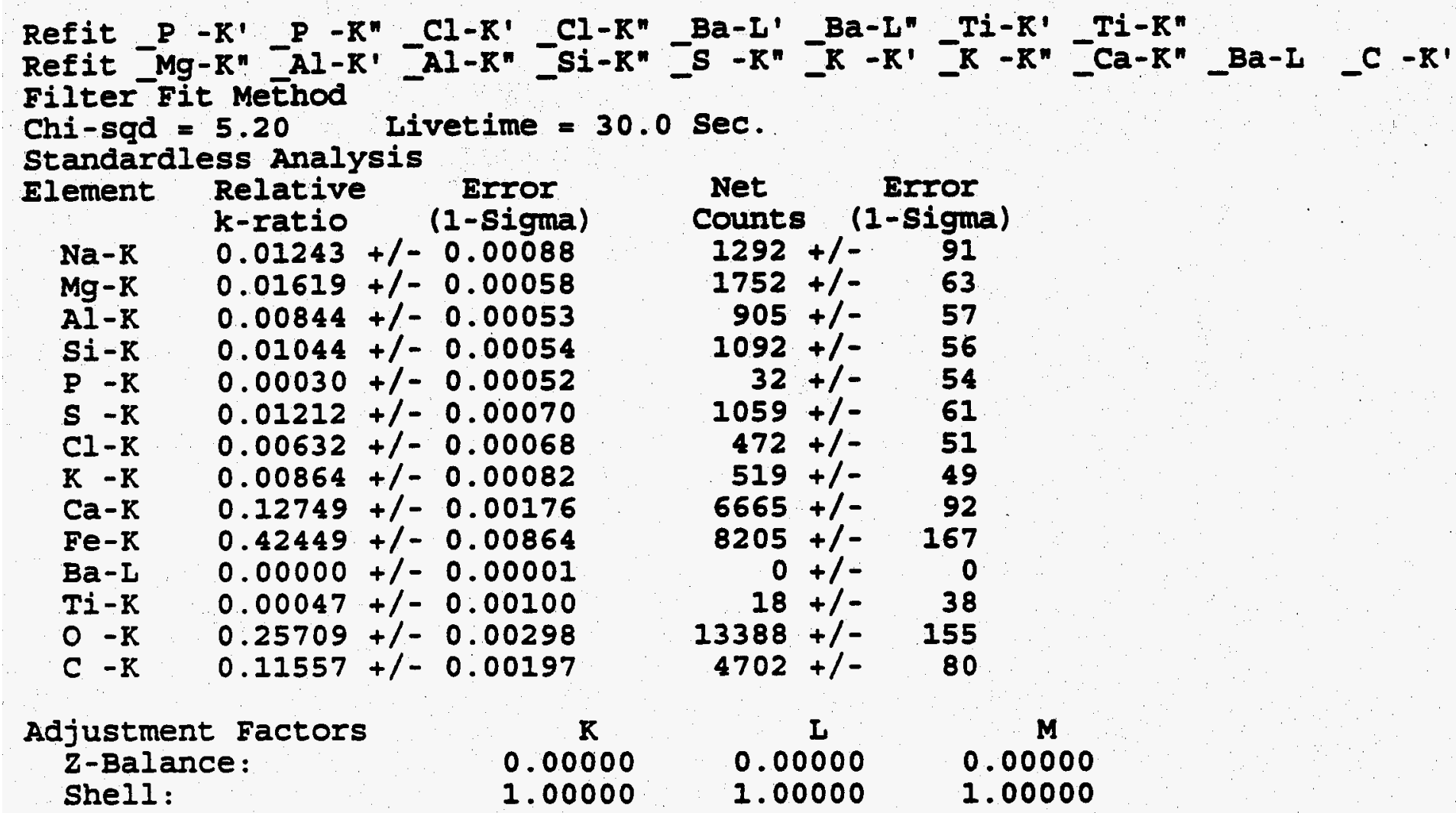

ZAF Correction ACC.Volt. $=15 \mathrm{kV}$ Take-off Angle $=44.22 \mathrm{deg}$ Number of Iterations $=6$

\begin{tabular}{|c|c|c|c|c|c|c|}
\hline $\begin{array}{l}\mathrm{Na}-\mathrm{K} \\
\mathrm{Mg}-\mathrm{K} \\
\mathrm{A} I-\mathrm{K} \\
\mathrm{S} \mathrm{I}-\mathrm{K} \\
\mathrm{P}-\mathrm{K} \\
\mathrm{S}-\mathrm{K} \\
\mathrm{Cl}-\mathrm{K} \\
\mathrm{K}-\mathrm{K} \\
\mathrm{Ca}-\mathrm{K} \\
\mathrm{Fe}-\mathrm{K} \\
\mathrm{Ba}-\mathrm{L} \\
\mathrm{T} \mathrm{i}-\mathrm{K} \\
\mathrm{O}-\mathrm{K} \\
\mathrm{C}-\mathrm{K} \\
\text { Total }\end{array}$ & $\begin{array}{c}\text { k-ratio } \\
\text { (calc.) } \\
0.0076 \\
0.0098 \\
0.0051 \\
0.0063 \\
0.0002 \\
0.0074 \\
0.0038 \\
0.0053 \\
0.0775 \\
0.2582 \\
0.0000 \\
0.0003 \\
0.1563 \\
0.0703\end{array}$ & $\begin{array}{l}2.521 \\
1.867 \\
1.593 \\
1.339 \\
1.261 \\
1.142 \\
1.144 \\
1.064 \\
1.036 \\
1.145 \\
1.275 \\
1.117 \\
2.392 \\
2.516\end{array}$ & $\begin{array}{r}\text { Atom } \\
1.72 \\
1.57 \\
0.63 \\
0.63 \\
0.02 \\
0.55 \\
0.26 \\
0.30 \\
4.17 \\
11.00 \\
0.00 \\
0.01 \\
48.57 \\
30.58 \\
100.00\end{array}$ & $\begin{array}{c}\text { Element } \\
\text { Wt } \\
1.91 \\
1.84 \\
0.82 \\
0.85 \\
0.02 \\
0.84 \\
0.44 \\
0.56 \\
8.04 \\
29.57 \\
0.00 \\
0.03 \\
37.40 \\
17.68 \\
100.00\end{array}$ & $\begin{array}{l}\text { Wt Err. } \\
\text { (1-Sigma) } \\
+/-0.13 \\
+/-0.07 \\
+/-0.05 \\
+/-0.04 \\
+/-0.04 \\
+/-0.05 \\
+/-0.05 \\
+/-0.05 \\
+/-0.11 \\
+/-0.60 \\
+/-0.00 \\
+/-0.07 \\
+/-0.43 \\
+/-0.30\end{array}$ & $\begin{array}{c}\text { No. of } \\
\text { Cations } \\
0.851 \\
0.777 \\
0.311 \\
0.311 \\
0.008 \\
0.269 \\
0.127 \\
0.147 \\
2.058 \\
5.436 \\
0.000 \\
0.007 \\
-2- \\
15.111 \\
25.413\end{array}$ \\
\hline
\end{tabular}

The number of cation results are based upon 24 oxygen atoms 
980428.1 .4

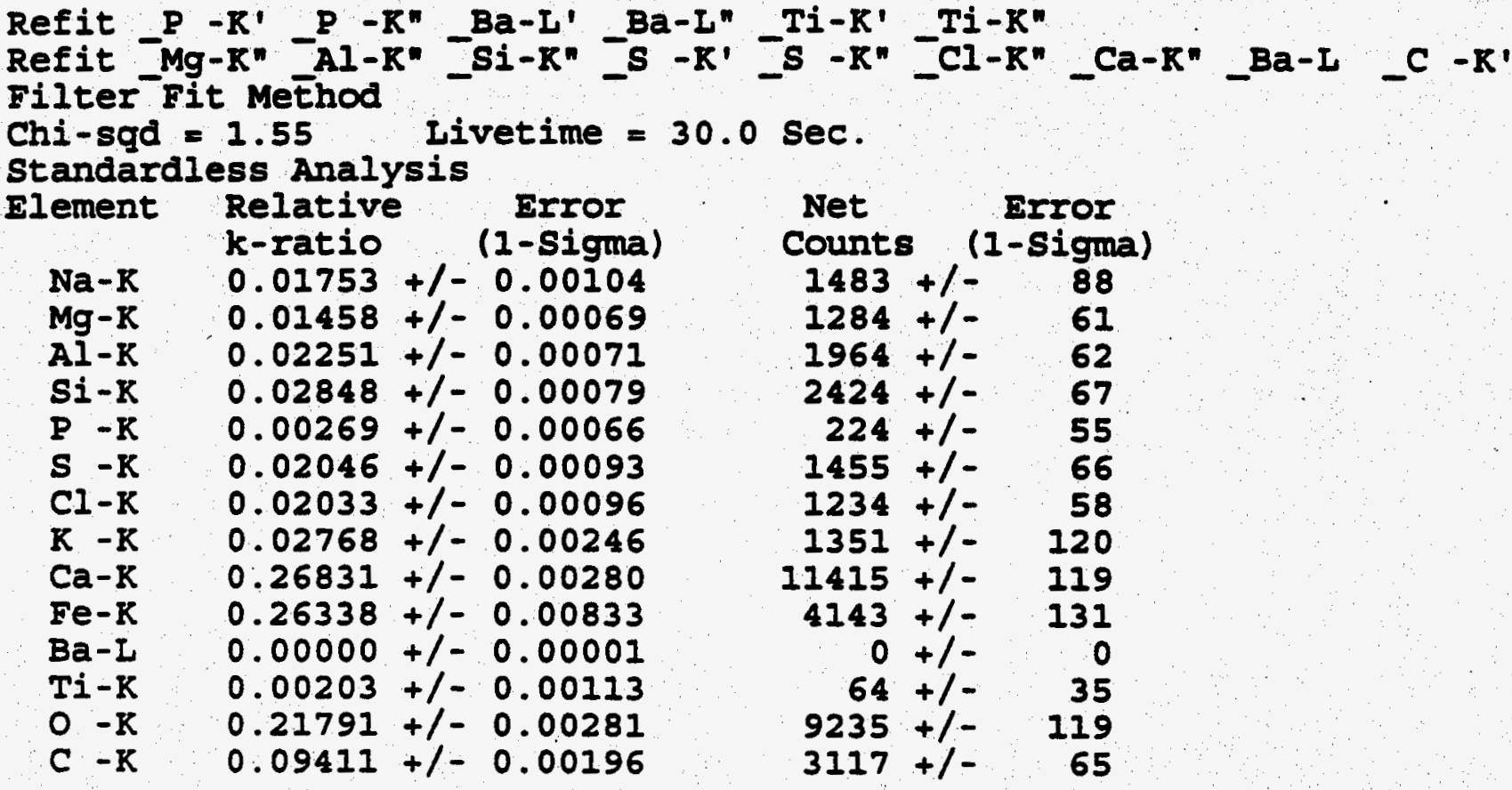

Adjustment Factors z-Balance :

0.00000

L

Shell:

1.00000

0.00000

$M$

1.00000

0.00000

1.00000

ZAF Correction Acc.Volt. $=15 \mathrm{kV}$ Take-off Angle $=44.22 \mathrm{deg}$ Number of Iterations $=5$

\begin{tabular}{|c|c|c|c|c|c|c|}
\hline $\begin{array}{l}N a-K \\
M g-K \\
A I-K \\
S i-K \\
P-K \\
S-K \\
C l-K \\
K-K \\
C a-K \\
F e-K \\
B a-I \\
T i-K \\
O-K \\
C-K \\
\text { Total }\end{array}$ & $\begin{array}{l}\text { k-ratio } \\
(c a 1 c .) \\
0.0102 \\
0.0085 \\
0.0131 \\
0.0166 \\
0.0016 \\
0.0119 \\
0.0118 \\
0.0161 \\
0.1564 \\
0.1535 \\
0.0000 \\
0.0012 \\
0.1270 \\
0.0548\end{array}$ & $\begin{array}{l}2.315 \\
1.755 \\
1.517 \\
1.303 \\
1.246 \\
1.133 \\
1.139 \\
1.060 \\
1.054 \\
1.161 \\
1.350 \\
1.167 \\
3.005 \\
2.698\end{array}$ & $\begin{array}{r}2.15 \\
1.28 \\
1.54 \\
1.61 \\
0.13 \\
0.88 \\
0.79 \\
0.91 \\
8.58 \\
6.65 \\
0.00 \\
0.06 \\
49.74 \\
25.69 \\
100.00\end{array}$ & $\begin{array}{c}\text { Element } \\
\text { Wt t } \\
2.36 \\
1.49 \\
1.99 \\
2.16 \\
0.20 \\
1.35 \\
1.35 \\
1.71 \\
16.48 \\
17.81 \\
0.00 \\
0.14 \\
38.16 \\
14.80 \\
100.00\end{array}$ & $\begin{array}{l}\text { Wt f Err. } \\
\text { (I-Sigma) } \\
+/-0.14 \\
+/-0.07 \\
+/-0.06 \\
+/-0.06 \\
+/-0.05 \\
+/-0.06 \\
+/-0.06 \\
+/-0.15 \\
+/-0.17 \\
+/-0.56 \\
+/-0.00 \\
+/-0.08 \\
+/-0.49 \\
+/-0.31\end{array}$ & $\begin{array}{c}\text { No. of } \\
\text { Cations } \\
1.035 \\
0.618 \\
0.742 \\
0.775 \\
0.063 \\
0.424 \\
0.383 \\
0.440 \\
4.138 \\
3.210 \\
0.000 \\
0.029 \\
--2 \\
12.396 \\
24.254\end{array}$ \\
\hline
\end{tabular}

The number of cation results are based upon 24 oxygen atoms 


$$
\begin{aligned}
& \text { - vessicular olag on } \\
& \text { coke particle } \\
& \text { - Photo only- no Hermal } \\
& \text { print }
\end{aligned}
$$

980428.2 .1

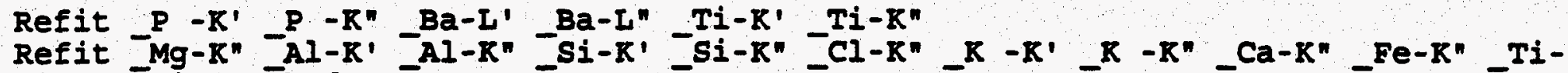
Filter Fit MeĒhod

Chi-sgd = $1.36 \quad$ Iivetime $=30.0 \mathrm{sec}$.

Standardless Analysis

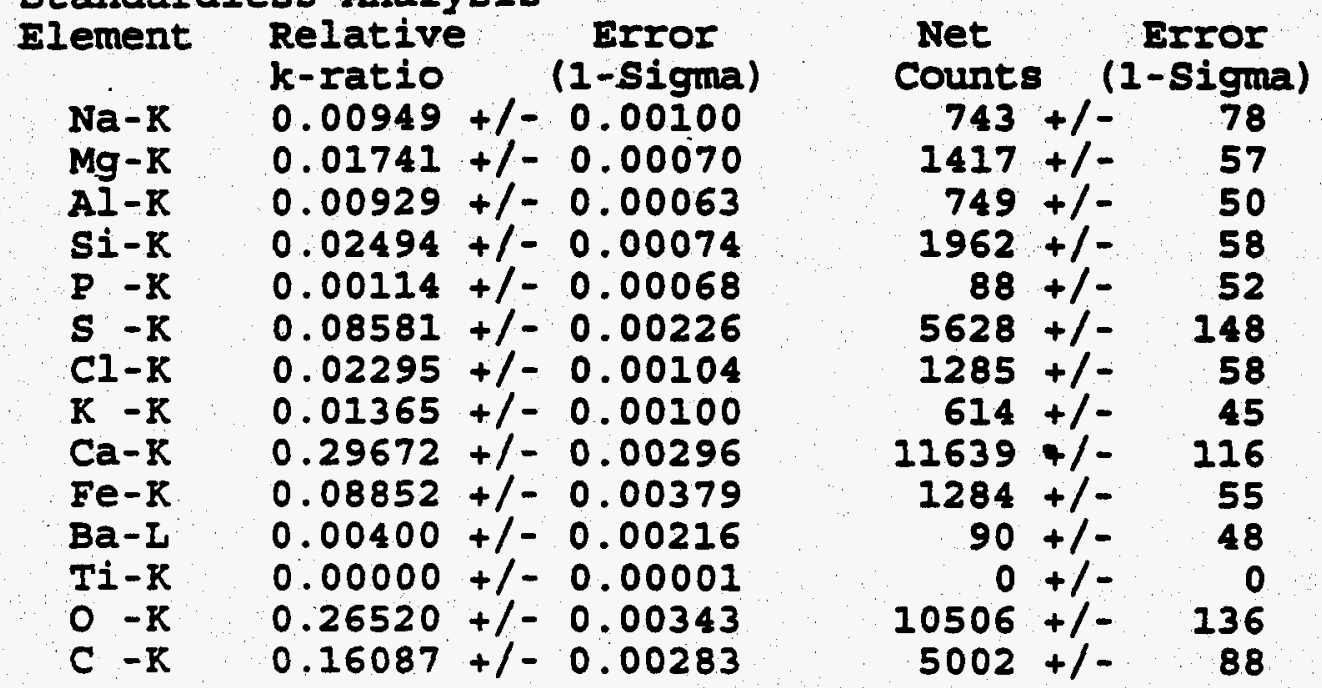

Adjustment Factors

0.00000

Z-Balance :

L

shell:

1.00000

0.00000

$M$

1.00000

0.00000

1.00000

\begin{tabular}{|c|c|c|c|c|c|c|}
\hline $\begin{array}{l}\mathrm{Na}-\mathrm{K} \\
\mathrm{Mg}-\mathrm{K} \\
\mathrm{Al}-\mathrm{K} \\
\mathrm{S} i-\mathrm{K} \\
\mathrm{P}-\mathrm{K} \\
\mathrm{S}-\mathrm{K} \\
\mathrm{Cl}-\mathrm{K} \\
\mathrm{K}-\mathrm{K} \\
\mathrm{Ca}-\mathrm{K} \\
\mathrm{F} e-\mathrm{K} \\
\mathrm{B} a-\mathrm{I} \\
\mathrm{T} i-\mathrm{K} \\
O-\mathrm{K} \\
\mathrm{C}-\mathrm{K} \\
\text { Total }\end{array}$ & $\begin{array}{l}\text { k-ratio } \\
\text { (calc.) } \\
0.0048 \\
0.0089 \\
0.0047 \\
0.0127 \\
0.0006 \\
0.0438 \\
0.0117 \\
0.0070 \\
0.1514 \\
0.0452 \\
0.0020 \\
0.0000 \\
0.1353 \\
0.0821\end{array}$ & $\begin{array}{l}2.107 \\
1.616 \\
1.430 \\
1.241 \\
1.201 \\
1.112 \\
1.150 \\
1.076 \\
1.075 \\
1.188 \\
1.400 \\
1.209 \\
3.281 \\
2.674\end{array}$ & $\begin{array}{r}0.81 \\
1.07 \\
0.46 \\
1.02 \\
0.04 \\
2.76 \\
0.69 \\
0.35 \\
7.38 \\
1.75 \\
0.04 \\
0.00 \\
50.43 \\
33.20 \\
100.00\end{array}$ & $\begin{array}{r}\text { Element } \\
\text { Wt } f \\
1.02 \\
1.44 \\
0.68 \\
1.58 \\
0.07 \\
4.87 \\
1.35 \\
0.75 \\
16.28 \\
5.37 \\
0.29 \\
0.00 \\
44.39 \\
21.94 \\
100.00\end{array}$ & $\begin{array}{l}\text { Wt Err } \\
\text { (1-sigma) } \\
+/-0.11 \\
+/-0.06 \\
+/-0.05 \\
+/-0.05 \\
+/-0.04 \\
+/-0.13 \\
+/-0.06 \\
+/-0.05 \\
+/-0.16 \\
+/-0.23 \\
+/-0.15 \\
+/-0.00 \\
+/-0.57 \\
+/-0.39\end{array}$ & $\begin{array}{r}\text { No. of } \\
\text { Cations } \\
0.384 \\
0.511 \\
0.217 \\
0.486 \\
0.019 \\
1.313 \\
0.329 \\
0.166 \\
3.513 \\
0.831 \\
0.018 \\
0.000 \\
-5- \\
15.800 \\
23.587\end{array}$ \\
\hline
\end{tabular}

ZAF Correction Acc.Volt $=15 \mathrm{kV}$ Take-off Angle $=45.96 \mathrm{deg}$ Number of Iterations $=6$

The number of cation results are based upon 24 Oxygen atoms 
980428.3 .1

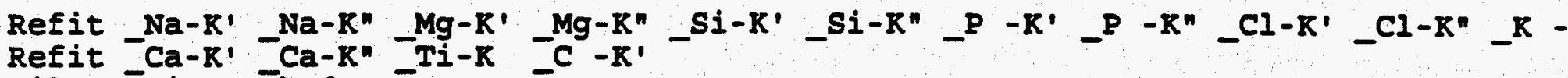
Filter Fit MeĚhod

Chi-sqd $=1.23 \quad$ Livetime $=30.0 \mathrm{sec}$.

Standardiess Analysis

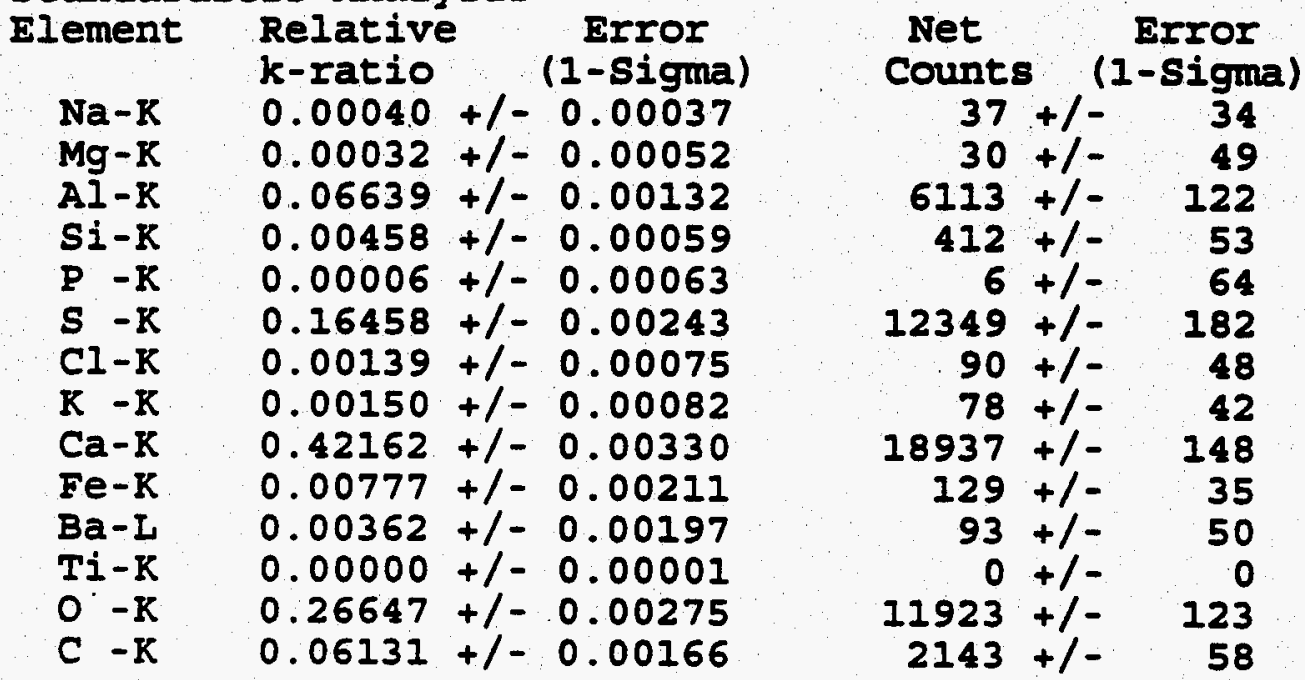

Adjustment Factors

Z-Balance:

Shell:

$\mathrm{K}$
0.00000
1.00000

0.00000

$\mathbf{M}$

1.00000

0.00000

ZAF Correction Acc.Volt. $=15 \mathrm{kV}$ Take-off Angle=44.22 deg Number of Iterations $=5$

\begin{tabular}{|c|c|c|c|c|c|c|}
\hline $\begin{array}{l}\text { Iement } \\
\text { Na-K } \\
M g-K \\
A I-K \\
S i-K \\
P-K \\
S-K \\
C I-K \\
K-K \\
C a-K \\
F e-K \\
B a-L \\
T i-K \\
O-K \\
C-K \\
\text { Total }\end{array}$ & $\begin{array}{c}\text { k-ratio } \\
\text { (calc.) } \\
0.0002 \\
0.0002 \\
0.0353 \\
0.0024 \\
0.0000 \\
0.0875 \\
0.0007 \\
0.0008 \\
0.2240 \\
0.0041 \\
0.0019 \\
0.0000 \\
0.1416 \\
0.0326\end{array}$ & $\begin{array}{l}2.098 \\
1.588 \\
1.393 \\
1.255 \\
1.172 \\
1.108 \\
1.171 \\
1.073 \\
1.079 \\
1.190 \\
1.424 \\
1.242 \\
3.494 \\
3.200\end{array}$ & $\begin{array}{r}\text { Atom } \\
0.04 \\
0.02 \\
3.59 \\
0.21 \\
0.00 \\
5.95 \\
0.05 \\
0.04 \\
11.88 \\
0.17 \\
0.04 \\
0.00 \\
60.91 \\
17.09 \\
100.00\end{array}$ & $\begin{array}{c}\text { Element } \\
\text { wt } \\
0.04 \\
0.03 \\
4.92 \\
0.31 \\
0.00 \\
9.69 \\
0.09 \\
0.09 \\
24.17 \\
0.49 \\
0.27 \\
0.00 \\
49.48 \\
10.42 \\
100.00\end{array}$ & $\begin{array}{l}\text { Wt Err } \\
\text { (1-sigma) } \\
+/-0.04 \\
+/-0.04 \\
+/-0.10 \\
+/-0.04 \\
+/-0.04 \\
+/-0.14 \\
+/-0.05 \\
+/-0.05 \\
+/-0.19 \\
+/-0.13 \\
+/-0.15 \\
+/-0.00 \\
+/-0.51 \\
+/-0.28\end{array}$ & $\begin{array}{r}\text { No. of } \\
\text { Cations } \\
0.015 \\
0.009 \\
1.414 \\
0.084 \\
0.001 \\
2.346 \\
0.019 \\
0.017 \\
4.681 \\
0.068 \\
0.015 \\
0.000 \\
-.- \\
6.735 \\
15.405\end{array}$ \\
\hline
\end{tabular}

The number of cation results are based upon 24 Oxygen atoms 
980428.3 .2

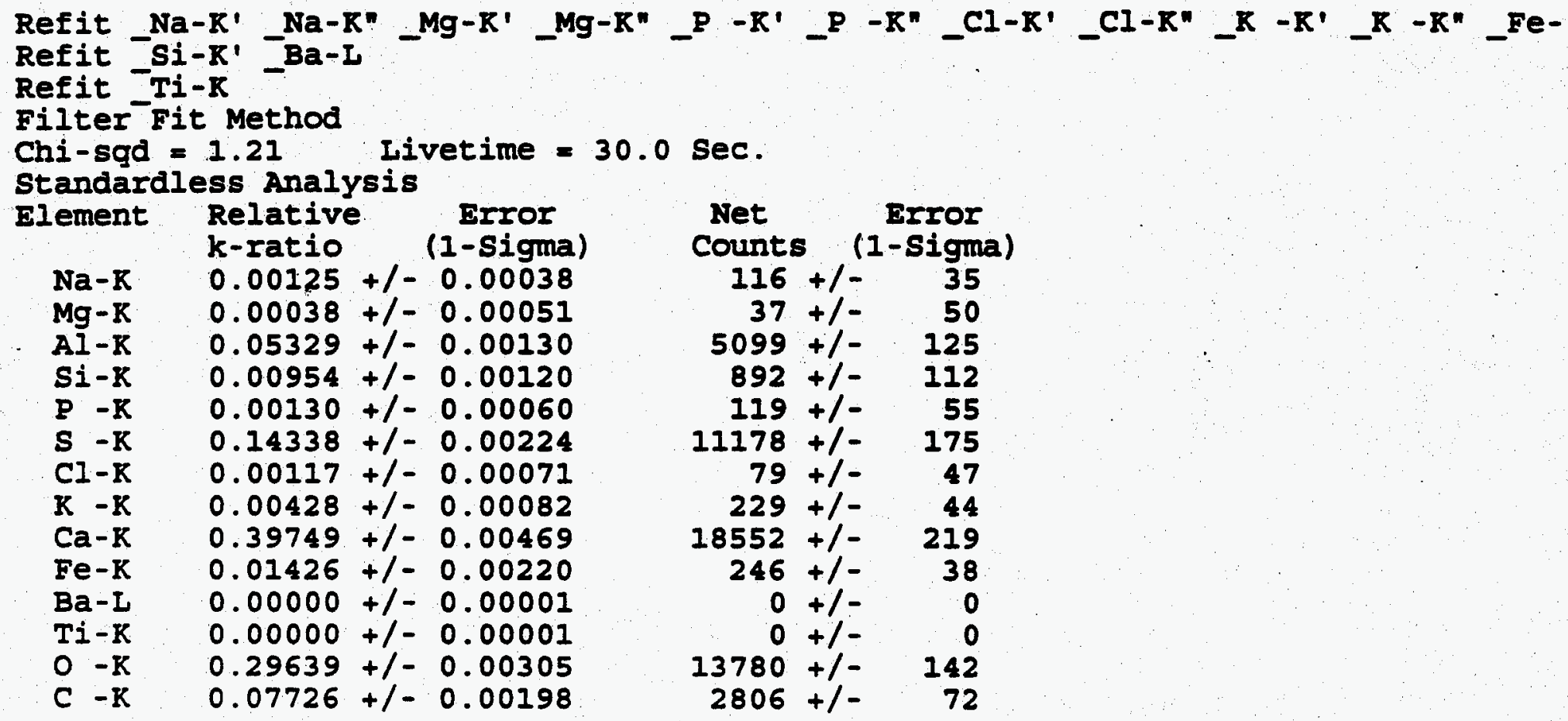

ZAF Correction Acc.Volt. $=15 \mathrm{kV}$ Number of Iterations $=\mathbf{5}$

\begin{tabular}{|c|c|c|c|c|c|c|}
\hline $\begin{array}{l}\mathrm{Na}-\mathrm{K} \\
\mathrm{Mg}-\mathrm{K} \\
\mathrm{Al}-\mathrm{K} \\
\mathrm{Si}-\mathrm{K} \\
\mathrm{P}-\mathrm{K} \\
\mathrm{S}-\mathrm{K} \\
\mathrm{Cl}-\mathrm{K} \\
\mathrm{K}-\mathrm{K} \\
\mathrm{Ca}-\mathrm{K} \\
\mathrm{Fe}-\mathrm{K} \\
\mathrm{Ba}-\mathrm{L} \\
\mathrm{T} \mathrm{i}-\mathrm{K} \\
\mathrm{O}-\mathrm{K} \\
\mathrm{C}-\mathrm{K} \\
\text { Total }\end{array}$ & $\begin{array}{l}\text { k-ratio } \\
\text { (calc.) } \\
0.0006 \\
0.0002 \\
0.0276 \\
0.0049 \\
0.0007 \\
0.0742 \\
0.0006 \\
0.0022 \\
0.2058 \\
0.0074 \\
0.0000 \\
0.0000 \\
0.1535 \\
0.0400\end{array}$ & $\begin{array}{l}2.118 \\
1.598 \\
1.401 \\
1.251 \\
1.199 \\
1.110 \\
1.165 \\
1.072 \\
1.079 \\
1.192 \\
1.444 \\
1.240 \\
3.367 \\
2.987\end{array}$ & $\begin{array}{r}\text { Atom } \\
0.11 \\
0.02 \\
2.74 \\
0.42 \\
0.05 \\
4.91 \\
0.04 \\
0.12 \\
10.59 \\
0.30 \\
0.00 \\
0.00 \\
61.69 \\
19.01 \\
100.00\end{array}$ & $\begin{array}{c}\text { Element } \\
\text { wt } \\
0.14 \\
0.03 \\
3.87 \\
0.62 \\
0.08 \\
8.24 \\
0.07 \\
0.24 \\
22.22 \\
0.88 \\
0.00 \\
0.00 \\
51.67 \\
11.95 \\
100.00\end{array}$ & $\begin{array}{l}\text { Wt Err } \\
\text { (1-Sigma) } \\
+/-0.04 \\
+/-0.04 \\
+/-0.09 \\
+/-0.08 \\
+/-0.04 \\
+/-0.13 \\
+/-0.04 \\
+/-0.05 \\
+/-0.26 \\
+/-0.14 \\
+/-0.00 \\
+/-0.00 \\
+/-0.53 \\
+/-0.31\end{array}$ & $\begin{array}{r}\text { No. of } \\
\text { Cations } \\
0.044 \\
0.010 \\
1.065 \\
0.164 \\
0.019 \\
1.911 \\
0.015 \\
0.045 \\
4.119 \\
0.117 \\
0.000 \\
0.000 \\
--5 \\
7.395 \\
14.904\end{array}$ \\
\hline
\end{tabular}

The number of cation results are based upon 24 oxygen atoms 
980428.3 .3

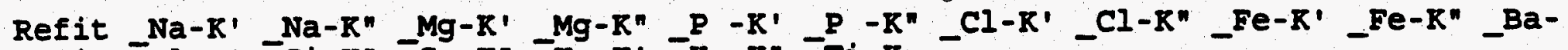
Refit -AI-K' -Si-K" - $S-K^{\prime \prime}-K-K^{\prime}$ - K $^{\prime} K^{\prime \prime}-T i-K$

Refit $A 1-\mathrm{K}$ "

Filter Fit Method

Chi-sqd $=1.22$ Livetime $=30.0 \mathrm{sec}$.

Standardless Analysis

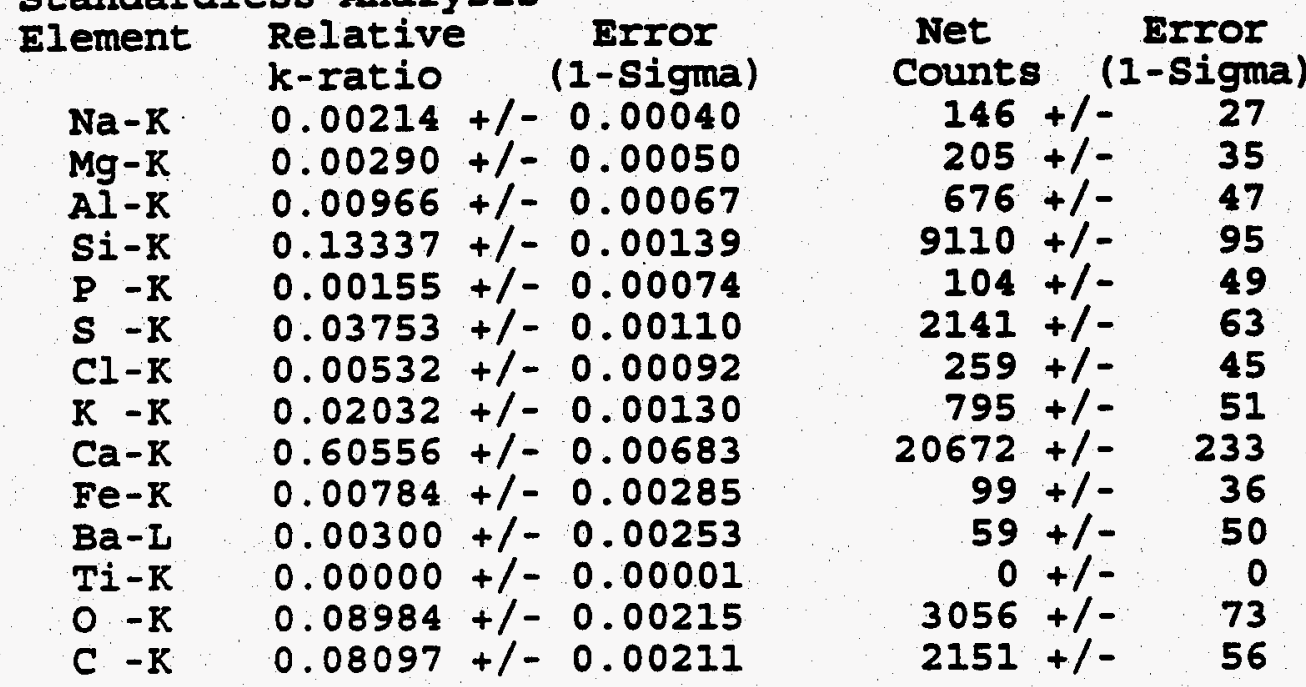

Adjustment Factors

$K$
0.00000
1.00000

Z-Balance:

L

$M$

Shel1:

1.00000

0.00000

0.00000

1.00000

1.00000

ZAF Correction Acc.Volt = $15 \mathrm{kV}$ Take-off Angle $=44.22 \mathrm{deg}$ Number of Iterations $=5$

\begin{tabular}{|c|c|c|c|c|c|c|}
\hline $\begin{array}{l}\mathrm{Na}-\mathrm{K} \\
\mathrm{Mg}-\mathrm{K} \\
\mathrm{A} I-\mathrm{K} \\
\mathrm{Si}-\mathrm{K} \\
\mathrm{P}-\mathrm{K} \\
\mathrm{S}-\mathrm{K} \\
\mathrm{Cl}-\mathrm{K} \\
\mathrm{K}-\mathrm{K} \\
\mathrm{C} a-\mathrm{K} \\
\mathrm{Fe}-\mathrm{K} \\
\mathrm{Ba}-\mathrm{I} \\
\mathrm{T} i-\mathrm{K} \\
\mathrm{O}-\mathrm{K} \\
\mathrm{C}-\mathrm{K} \\
\text { Total }\end{array}$ & $\begin{array}{l}\text { k-ratio } \\
\text { (calc.) } \\
0.0013 \\
0.0018 \\
0.0061 \\
0.0841 \\
0.0010 \\
0.0237 \\
0.0034 \\
0.0128 \\
0.3818 \\
0.0049 \\
0.0019 \\
0.0000 \\
0.0566 \\
0.0511\end{array}$ & $\begin{array}{l}2.026 \\
1.552 \\
1.366 \\
1.199 \\
1.235 \\
1.125 \\
1.133 \\
1.024 \\
1.065 \\
1.185 \\
1.448 \\
1.260 \\
4.975 \\
2.807\end{array}$ & $\begin{array}{r}0.26 \\
0.26 \\
0.68 \\
7.93 \\
0.09 \\
1.83 \\
0.24 \\
0.74 \\
22.42 \\
0.23 \\
0.04 \\
0.00 \\
38.91 \\
26.36 \\
100.00\end{array}$ & $\begin{array}{c}\text { Element } \\
\text { wt t } \\
0.27 \\
0.28 \\
0.83 \\
10.08 \\
0.12 \\
2.66 \\
0.38 \\
1.31 \\
40.68 \\
0.59 \\
0.27 \\
0.00 \\
28.18 \\
14.33 \\
100.00\end{array}$ & $\begin{array}{l}\text { Wt Err. } \\
\text { (1-Sigma) } \\
+/-0.05 \\
+/-0.05 \\
+/-0.06 \\
+/-0.11 \\
+/-0.06 \\
+/-0.08 \\
+/-0.07 \\
+/-0.08 \\
+/-0.46 \\
+/-0.21 \\
+/-0.23 \\
+/-0.00 \\
+/-0.67 \\
+/-0.37\end{array}$ & $\begin{array}{c}\text { No. of } \\
\text { Cations } \\
0.162 \\
0.159 \\
0.420 \\
4.890 \\
0.053 \\
1.131 \\
0.146 \\
0.457 \\
13.830 \\
0.143 \\
0.027 \\
0.000 \\
-2- \\
16.257 \\
37.675\end{array}$ \\
\hline
\end{tabular}

The number of cation results are based upon 24 oxygen atoms 
980427.1 .1

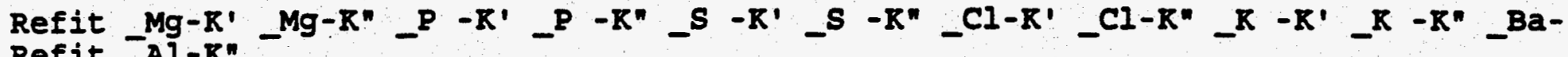
Refit Al-K"

Filter Fit Method

Chi-sgd $=3.66 \quad$ Iivetime $=30.0 \mathrm{sec}$.

standardless Analysis

Element

\section{Relative}

k-ratio

\section{Error}

(1-Sigma)

Na-K

$\mathrm{Mg}-\mathrm{K}$

AI-K

$0.01804+1-$

$0.00440+1-$
$0.02584+1-$

0.13363

$+1-$

$\mathrm{P}-\mathrm{K}$

0.00160

0.00463

$0.00197+1-$

$0.00494+1-$

$0.31384+1-$

$0.24659+1-$

$0.00221+1=$

$0.01479+1$

$0.13835+1-$

$0.08918+1=$

0.00087

0.00060

0.00073

0.00199

0.00062

Cl-K

$\mathrm{K}-\mathrm{K}$

Fe-K

$\mathrm{Ba}-\mathrm{L}$

$\mathrm{T} i-\mathrm{K}$

O $-K$

C $-K$

$\begin{array}{rr}\text { Net } & \text { Error } \\ \text { Counts } & (1-\text { Sigma }) \\ 1636+/- & 79 \\ 416+/- & 57 \\ 2414+/- & 69 \\ 12181+/- & 181 \\ 142+/- & 55 \\ 353+/- & 51 \\ 128+/- & 46 \\ 259+/- & 46 \\ 14299+/- & 202 \\ 4154+/- & 132 \\ 57+/- & 81 \\ 492+/- & 54 \\ 6279+/- & 115 \\ 3163+/- & 73\end{array}$

$M$

0.00000

1.00000

0.00000

1.00000

z-Balance:

shell:

$\mathrm{K}$
0.00000
1.00000

ZAF Correction Acc. Volt. $=15 \mathrm{kV}$ Take-off Angle $=44.22 \mathrm{deg}$ Number of Iterations $=5$

\begin{tabular}{|c|c|c|c|c|c|c|}
\hline $\begin{array}{l}N a-K \\
M g-K \\
A I-K \\
S i-K \\
P-K \\
S-K \\
C l-K \\
K-K \\
C a-K \\
F e-K \\
B a-I \\
T i-K \\
O-K \\
C-K \\
\text { Total }\end{array}$ & $\begin{array}{l}\text { k-ratio } \\
\text { (calc.) } \\
0.0110 \\
0.0027 \\
0.0157 \\
0.0811 \\
0.0010 \\
0.0028 \\
0.0012 \\
0.0030 \\
0.1905 \\
0.1497 \\
0.0013 \\
0.0090 \\
0.0840 \\
0.0541\end{array}$ & $\begin{array}{l}2.222 \\
1.702 \\
1.467 \\
1.277 \\
1.296 \\
1.166 \\
1.155 \\
1.057 \\
1.050 \\
1.158 \\
1.364 \\
1.171 \\
3.394 \\
3.041\end{array}$ & $\begin{array}{r}\text { Atom } \\
2.31 \\
0.41 \\
1.86 \\
8.03 \\
0.09 \\
0.22 \\
0.08 \\
0.18 \\
10.87 \\
6.76 \\
0.03 \\
0.48 \\
38.82 \\
29.86 \\
100.00\end{array}$ & $\begin{array}{r}\text { Element } \\
\text { wt } \\
2.43 \\
0.46 \\
2.30 \\
10.36 \\
0.13 \\
0.33 \\
0.14 \\
0.32 \\
20.01 \\
17.34 \\
0.18 \\
1.05 \\
28.51 \\
16.46 \\
100.00\end{array}$ & $\begin{array}{l}\text { Wt Err. } \\
\text { (1-Sigma) } \\
+/-0.12 \\
+/-0.06 \\
+/-0.07 \\
+/-0.15 \\
+/-0.05 \\
+/-0.05 \\
+/-0.05 \\
+/-0.06 \\
+/-0.28 \\
+/-0.55 \\
+/-0.26 \\
+/-0.12 \\
+/-0.52 \\
+/-0.38\end{array}$ & $\begin{array}{r}\text { No. of } \\
\text { Cations } \\
1.426 \\
0.252 \\
1.149 \\
4.967 \\
0.055 \\
0.138 \\
0.053 \\
0.109 \\
6.724 \\
4.181 \\
0.018 \\
0.296 \\
-.5 \\
18.464 \\
37.831\end{array}$ \\
\hline
\end{tabular}

The number of cation results are based upon 24 oxygen atoms 
980427.1 .3

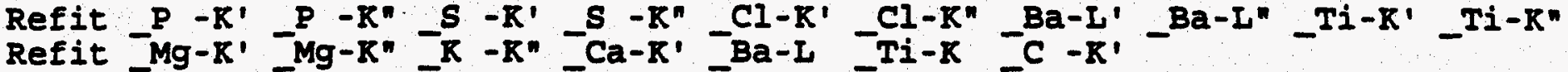
Filter Fit MeĚhod

Chi-sqd $=2.30 \quad$ Livetime $=30.0 \mathrm{sec}$.

Standardless Analysis

Element

Relative $\quad$ Error
k-ratio

$\mathrm{Na}-\mathrm{K} \quad 0.01045+/-0.00076$

$\mathrm{Mg}-\mathrm{K} \quad 0.00889+/-0.00063$

AI-K $\quad 0.01394+/-0.00127$

Si-K $\quad 0.04033+/-0.00144$

P $-\mathrm{K} \quad 0.00272+/-0.00059$

S $-\mathrm{K} \quad 0.00730+/-0.00070$

Cl-K $\quad 0.00667+/-0.00075$

$\mathrm{K}-\mathrm{K} \quad 0.01611+/-0.00097$

$\mathrm{Ca}-\mathrm{K} \quad 0.10544+/-0.00312$

Fe-K $\quad 0.54625+/-0.01000$

$\mathrm{Ba}-\mathrm{I} \quad 0.00000+/-0.00001$

Ti-K $\quad 0.00000+/-0.00001$

$0-\mathrm{K} \quad 0.14363+/-0.00224$

C $-K$

$0.09826+/-0.00175$

$\begin{array}{rr}\text { Net } & \text { Error } \\ \text { Counts } & \text { (1-Sigma) } \\ 1051+/- & 76 \\ 931+/- & 66 \\ 1445+/- & 131 \\ 4081+/- & 146 \\ 268+/- & 58 \\ 617+/- & 59 \\ 481+/- & 54 \\ 934+/- & 56 \\ 5332+/- & 158 \\ 10214+/- & 187 \\ 0+/- & 0 \\ 0+/- & 0 \\ 7236+/- & 113 \\ 3867+/- & 69\end{array}$

Adjustment Factors

Z-Balance:

Shell:

$\begin{array}{ccc}\mathrm{K} & \mathrm{I} & \mathrm{M} \\ 0.00000 & 0.00000 & 0.00000 \\ 1.00000 & 1.00000 & 1.00000\end{array}$

ZAF Correction Acc.Volt. $=15 \mathrm{kV}$ Take-off Angle $=44.22 \mathrm{deg}$ Number of Iterations $=6$

\begin{tabular}{|c|c|c|c|c|c|c|c|}
\hline $\begin{array}{l}N a-K \\
M g-K \\
A I-K \\
S i-K \\
P-K \\
S-K \\
C l-K \\
K-K \\
C a-K \\
F e-K \\
B a-I \\
T i-K \\
O-K \\
C-K \\
\text { Total }\end{array}$ & $\begin{array}{c}\text { k-ratio } \\
\text { (calc.) } \\
0.0069 \\
0.0059 \\
0.0092 \\
0.0266 \\
0.0018 \\
0.0048 \\
0.0044 \\
0.0106 \\
0.0697 \\
0.3610 \\
0.0000 \\
0.0000 \\
0.0949 \\
0.0649\end{array}$ & $\begin{array}{l}2.591 \\
1.903 \\
1.603 \\
1.349 \\
1.286 \\
1.155 \\
1.146 \\
1.058 \\
1.024 \\
1.122 \\
1.236 \\
1.063 \\
2.471 \\
2.850\end{array}$ & $\begin{array}{r}1.82 \\
1.07 \\
1.28 \\
2.99 \\
0.17 \\
0.41 \\
0.33 \\
0.67 \\
4.16 \\
16.93 \\
0.00 \\
0.00 \\
34.21 \\
35.96 \\
100.00\end{array}$ & $\begin{array}{r}\text { Element } \\
\text { wt } \\
1.79 \\
1.12 \\
1.48 \\
3.59 \\
0.23 \\
0.56 \\
0.51 \\
1.13 \\
7.14 \\
40.50 \\
0.00 \\
0.00 \\
23.45 \\
18.51 \\
100.00\end{array}$ & 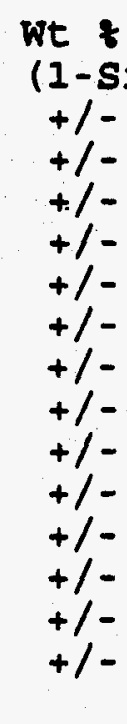 & $\begin{array}{l}\text { Err: } \\
\text { igma) } \\
0.13 \\
0.08 \\
0.13 \\
0.13 \\
0.05 \\
0.05 \\
0.06 \\
0.07 \\
0.21 \\
0.74 \\
0.00 \\
0.00 \\
0.37 \\
0.33\end{array}$ & $\begin{array}{r}\text { No. of } \\
\text { Cations } \\
1.274 \\
0.753 \\
0.896 \\
2.095 \\
0.122 \\
0.285 \\
0.233 \\
0.472 \\
2.915 \\
11.874 \\
0.000 \\
0.000 \\
-2- \\
25.227 \\
46.146\end{array}$ \\
\hline
\end{tabular}

The number of cation results are based upon 24 oxygen atoms 
980427.2 .2

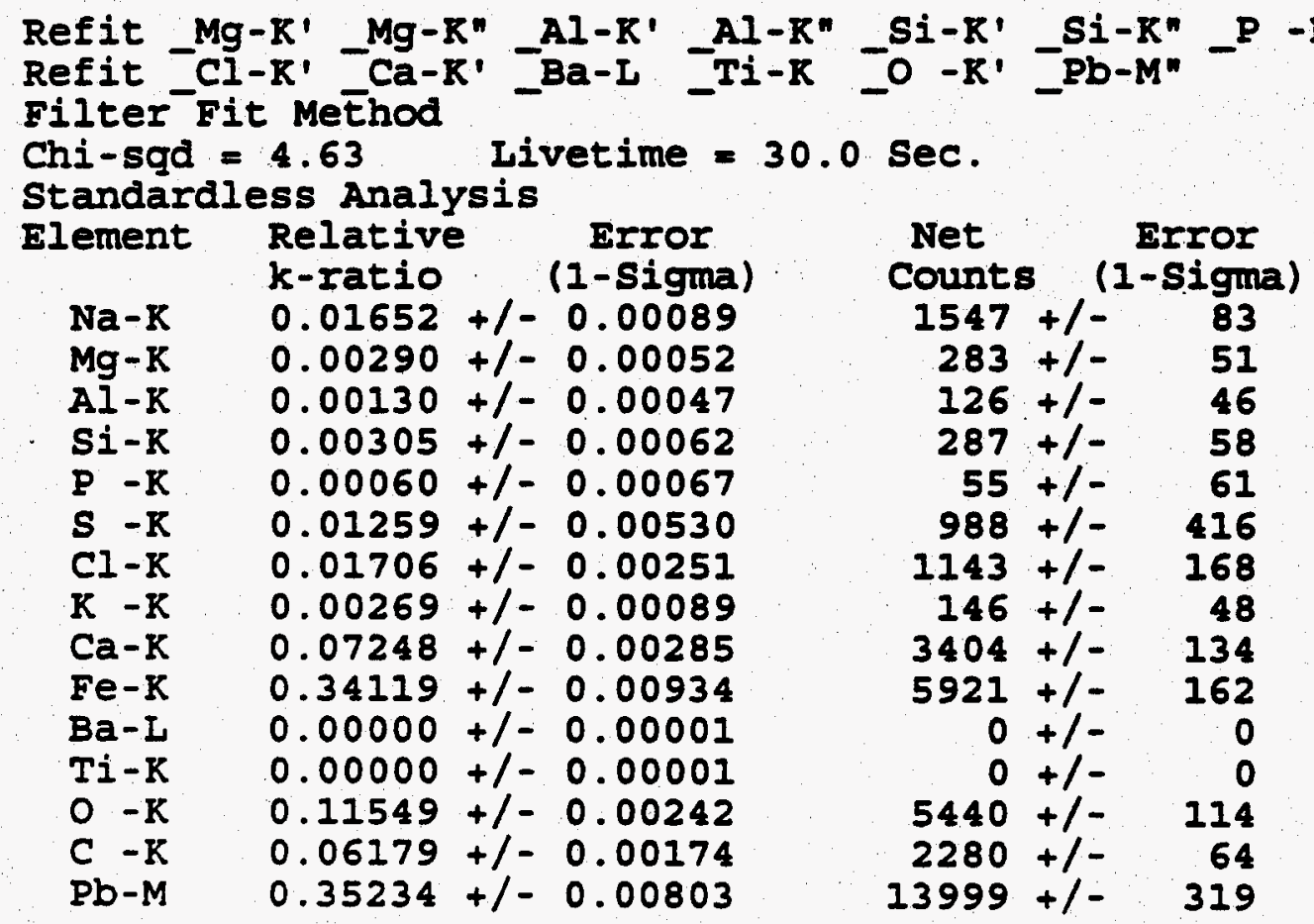

Adjustment Factors

Z-Balance:

Shell:
$K$
0.00000
1.00000
I

0.00000

1.00000
$M$

0.00000

1.00000

ZAF Correction Acc.Volt. $=15 \mathrm{kV}$ Take-off Angle $=45.10 \mathrm{deg}$ Number of Iterations $=5$

\begin{tabular}{|c|c|c|c|c|c|c|}
\hline $\begin{array}{l}N a-K \\
M g-K \\
A I-K \\
S i-K \\
P-K \\
S-K \\
C I-K \\
K-K \\
C a-K \\
F e-K \\
B a-I \\
T i-K \\
O-K \\
C-K \\
P b-M \\
T o t a l\end{array}$ & $\begin{array}{c}\text { k-ratio } \\
\text { (calc.) } \\
0.0117 \\
0.0021 \\
0.0009 \\
0.0022 \\
0.0004 \\
0.0089 \\
0.0121 \\
0.0019 \\
0.0513 \\
0.2413 \\
0.0000 \\
0.0000 \\
0.0817 \\
0.0437 \\
0.2492\end{array}$ & $\begin{array}{l}2.289 \\
1.753 \\
1.492 \\
1.252 \\
1.168 \\
1.068 \\
1.247 \\
1.122 \\
1.060 \\
1.048 \\
1.246 \\
1.071 \\
2.487 \\
2.454 \\
1.286\end{array}$ & $\begin{array}{r}\text { Atom } \\
3.72 \\
0.47 \\
0.16 \\
0.31 \\
0.05 \\
0.95 \\
1.36 \\
0.17 \\
4.33 \\
14.47 \\
0.00 \\
0.00 \\
40.55 \\
28.52 \\
4.94 \\
100.00\end{array}$ & $\begin{array}{c}\text { Element } \\
\text { Wt } \% \\
2.68 \\
0.36 \\
0.14 \\
0.27 \\
0.05 \\
0.95 \\
1.51 \\
0.21 \\
5.43 \\
25.30 \\
0.00 \\
0.00 \\
20.32 \\
10.73 \\
32.05 \\
100.00\end{array}$ & $\begin{array}{l}\text { wt Err. } \\
\text { (1-Sigma) } \\
+/-0.14 \\
+/-0.07 \\
+/-0.05 \\
+/-0.05 \\
+/-0.06 \\
+/-0.40 \\
+/-0.22 \\
+/-0.07 \\
+/-0.21 \\
+/-0.69 \\
+/-0.00 \\
+/-0.00 \\
+/-0.43 \\
+/-0.30 \\
+/-0.73\end{array}$ & $\begin{array}{c}\text { No. of } \\
\text { Cations } \\
2.199 \\
0.279 \\
0.096 \\
0.182 \\
0.030 \\
0.561 \\
0.802 \\
0.103 \\
2.563 \\
8.563 \\
0.000 \\
0.000 \\
-.- \\
16.878 \\
2.924 \\
35.180\end{array}$ \\
\hline
\end{tabular}

The number of cation results are based upon 24 oxygen atoms 
980426.1 .1

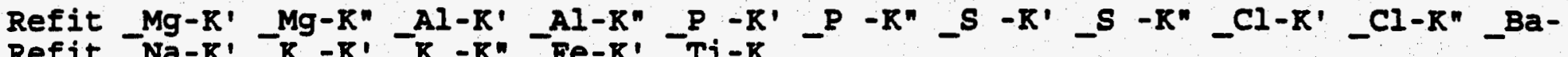
Refit ENa-K' KK-K' -K-K' Ee-K' -Ti-K

Filter Fit MeĒhod

Chi-sqd $=1.03 \quad$ Iivetime $=30.0 \mathrm{sec}$.

Standardless Analysis

Element

\section{Relative}

Error

$\mathrm{Na}-\mathrm{K}$

k-ratio

(1-sigma)

$\mathrm{Mg}-\mathrm{K}$

$0.00504+/-0.00072$

$A l-K$

$0.00787+/-0.00055$

Si-K

$0.00510+/-0.00063$

P $-K$

$0.01768+1-0.00139$

S. $-K$

$0.00172+/-0.00081$

Cl-K

$0.03188+/-0.00128$

$\mathrm{K}-\mathrm{K}$

$0.01250+/-0.00108$

$\mathrm{Ca}-\mathrm{K}$

$0.01780+/-0.00138$

$\mathrm{Fe}-\mathrm{K}$

$0.54328+/-0.00681$

$\mathrm{Ba}-\mathrm{I}$

$0.14024+/-0.00887$

Ti-K

$0.00095+/-0.00284$

O $-K$

$0.00000+/-0.00001$

C $-K$

$0.05777+/-0.00204$

$\mathrm{Pb}-\mathrm{M}$

$0.15324+/-0.00274$

$0.00494+/-0.00447$

Adjustment Factors

Z-Balance:

Shell:

$K$
0.00000
1.00000

$\begin{array}{rr}\text { Net } & \text { Error } \\ \text { Counts } & \text { (1-Sigma) } \\ 317+/- & 45 \\ 516+/- & 36 \\ 332+/- & 41 \\ 1122+/- & 88 \\ 106+/- & 50 \\ 1688+/- & 68 \\ 566+/- & 49 \\ 648+/- & 50 \\ 17230+/- & 216 \\ 1645+/- & 104 \\ 18+/- & 53 \\ 0+/- & 0 \\ 1812+/- & 64 \\ 3744+/- & 67 \\ 132+/- & 120\end{array}$

ZAF Correction Acc.Volt. $=15 \mathrm{kV}$ Take-off Angle $=43.31$ deg Number of Iterations $=5$

\begin{tabular}{|c|c|c|c|c|c|c|}
\hline $\begin{array}{l}\text { lement } \\
\text { Na-K } \\
\text { Mg-K } \\
\text { AI-K } \\
S i-K \\
P-K \\
S-K \\
C l-K \\
K-K \\
C a-K \\
\text { Fe-K } \\
\text { Ba-L } \\
\text { Ti-K } \\
O-K \\
C-K \\
\text { Pb-M } \\
\text { Total }\end{array}$ & $\begin{array}{c}\text { k-ratio } \\
\text { (calc.) } \\
0.0033 \\
0.0052 \\
0.0034 \\
0.0118 \\
0.0011 \\
0.0212 \\
0.0083 \\
0.0118 \\
0.3610 \\
0.0932 \\
0.0006 \\
0.0000 \\
0.0384 \\
0.1018 \\
0.0033\end{array}$ & $\begin{array}{l}2.209 \\
1.667 \\
1.449 \\
1.243 \\
1.194 \\
1.093 \\
1.107 \\
1.007 \\
1.049 \\
1.171 \\
1.417 \\
1.226 \\
5.072 \\
2.271 \\
1.313\end{array}$ & $\begin{array}{r}0.71 \\
0.79 \\
0.40 \\
1.14 \\
0.10 \\
1.58 \\
0.57 \\
0.67 \\
20.73 \\
4.29 \\
0.01 \\
0.00 \\
26.71 \\
42.26 \\
0.05 \\
100.00\end{array}$ & $\begin{array}{c}\text { Element } \\
\text { Wt } \\
0.74 \\
0.87 \\
0.49 \\
1.46 \\
0.14 \\
2.31 \\
0.92 \\
1.19 \\
37.85 \\
10.91 \\
0.09 \\
0.00 \\
19.47 \\
23.12 \\
0.43 \\
100.00\end{array}$ & $\begin{array}{l}\text { wt Err. } \\
\text { (1-sigma) } \\
+/-0.10 \\
+/-0.06 \\
+/-0.06 \\
+/-0.11 \\
+/-0.06 \\
+/-0.09 \\
+/-0.08 \\
+/-0.09 \\
+/-0.47 \\
+/-0.69 \\
+/-0.27 \\
+/-0.00 \\
+/-0.69 \\
+/-0.41 \\
+/-0.39\end{array}$ & $\begin{array}{c}\text { No. of } \\
\text { Cations } \\
0.634 \\
0.707 \\
0.359 \\
1.026 \\
0.087 \\
1.424 \\
0.512 \\
0.601 \\
18.628 \\
3.854 \\
0.013 \\
0.000 \\
-0- \\
37.972 \\
0.041 \\
65.857\end{array}$ \\
\hline
\end{tabular}

The number of cation results are based upon 24 Oxygen atoms 
980426.1 .2

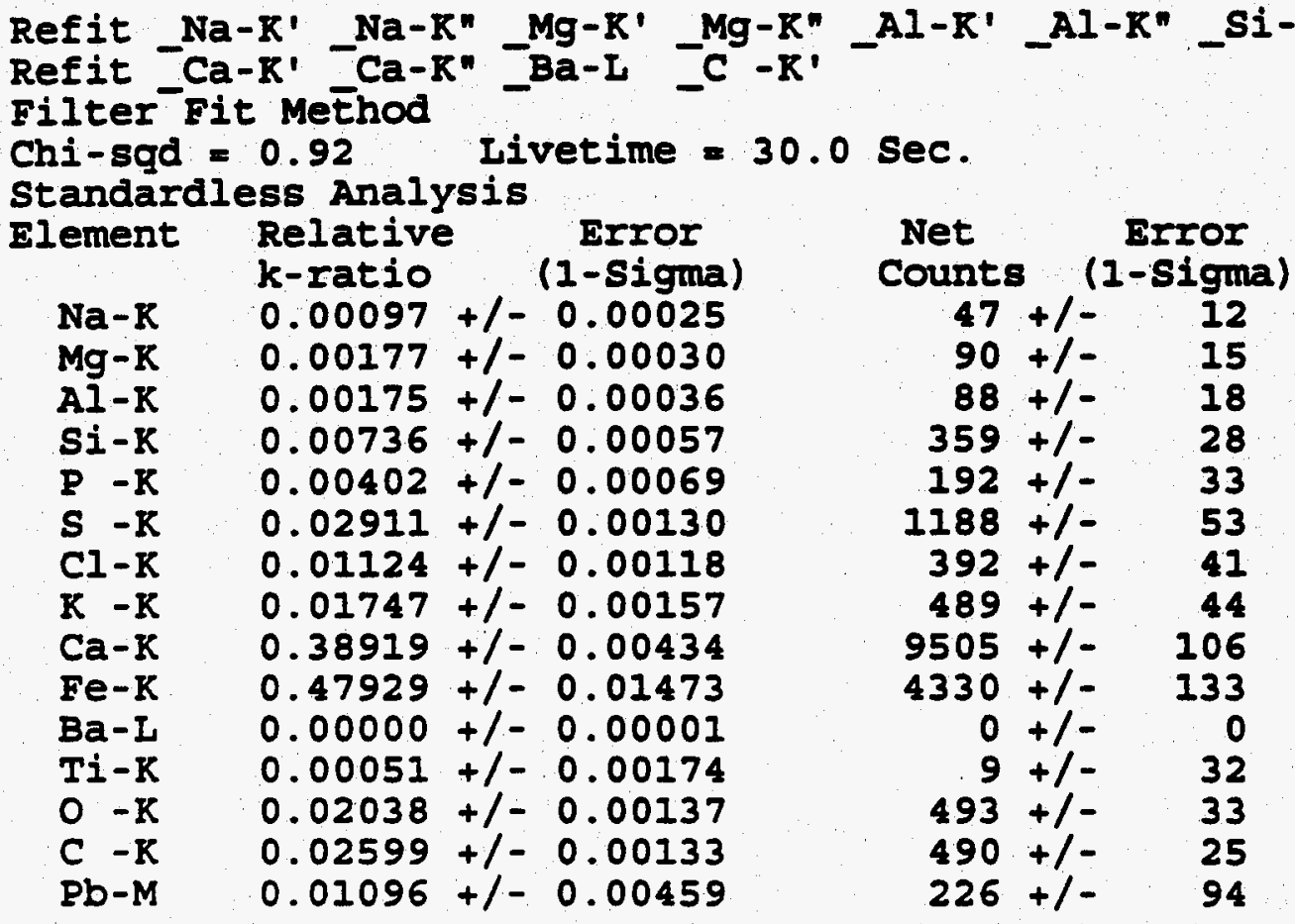

Adjustment Factors

z-Balance:

Shell:

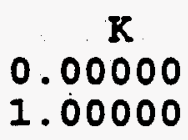

I

0.00000
1.00000
$M$

0.00000

1.00000

ZAF Correction Acc.Volt. $=15 \mathrm{kV}$ Take-off Angle $=43.31 \mathrm{deg}$ Number of Iterations $=4$

\begin{tabular}{|c|c|c|c|c|c|c|}
\hline $\begin{array}{l}N a-K \\
M g-K \\
A I-K \\
S i-K \\
P-K \\
S-K \\
C l-K \\
K-K \\
C a-K \\
F e-K \\
B a-I \\
T i-K \\
O-K \\
C-K \\
P b-M \\
\text { Total }\end{array}$ & $\begin{array}{l}\text { k-ratio } \\
\text { (calc.) } \\
0.0008 \\
0.0015 \\
0.0015 \\
0.0064 \\
0.0035 \\
0.0252 \\
0.0097 \\
0.0151 \\
0.3369 \\
0.4149 \\
0.0000 \\
0.0004 \\
0.0176 \\
0.0225 \\
0.0095\end{array}$ & $\begin{array}{l}2.629 \\
1.902 \\
1.585 \\
1.313 \\
1.223 \\
1.100 \\
1.106 \\
0.997 \\
0.999 \\
1.092 \\
1.303 \\
1.123 \\
3.609 \\
2.670 \\
1.319\end{array}$ & $\begin{array}{r}0.34 \\
0.43 \\
0.32 \\
1.07 \\
0.49 \\
3.10 \\
1.09 \\
1.38 \\
30.14 \\
29.12 \\
0.00 \\
0.04 \\
14.29 \\
17.96 \\
0.22 \\
100.00\end{array}$ & $\begin{array}{c}\text { Element } \\
\text { Wt } t \\
0.22 \\
0.29 \\
0.24 \\
0.84 \\
0.43 \\
2.77 \\
1.08 \\
1.51 \\
33.65 \\
45.30 \\
0.00 \\
0.05 \\
6.37 \\
6.01 \\
1.25 \\
100.00\end{array}$ & $\begin{array}{l}\text { Wt Err } \\
\text { (1-Sigma) } \\
+/-0.06 \\
+/-0.05 \\
+/-0.05 \\
+/-0.07 \\
+/-0.07 \\
+/-0.12 \\
+/-0.11 \\
+/-0.14 \\
+/-0.38 \\
+/-1.39 \\
+/-0.00 \\
+/-0.17 \\
+/-0.43 \\
+/-0.31 \\
+/-0.52\end{array}$ & $\begin{array}{r}\text { No. of } \\
\text { Cations } \\
0.57 \\
0.72 \\
0.538 \\
1.79 \\
0.82 \\
5.21 \\
1.83 \\
2.32 \\
50.64 \\
48.928 \\
0.00 \\
0.06 \\
-.- \\
30.16 \\
0.36 \\
143.99\end{array}$ \\
\hline
\end{tabular}

The number of cation results are based upon 24 oxygen atoms 
980426.1 .3

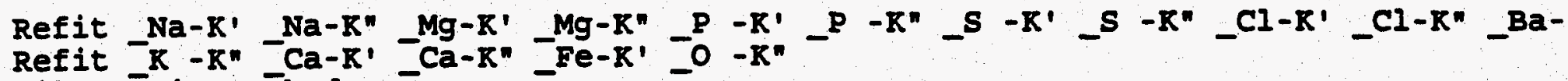

Filter Fit Method

Chi-sqd $=0.91$ Livetime $=30.0 \mathrm{sec}$.

standardless Analysis

$\begin{array}{cccc}\text { Element } & \begin{array}{l}\text { Relative } \\ \text { k-ratio }\end{array} \text { Error } & \begin{array}{c}\text { Net } \\ \text { Counts }\end{array} & \begin{array}{c}\text { Error } \\ \text { (1-Sigma) }\end{array} \\ \mathrm{Na}-\mathrm{K} & 0.00296+/-0.00052 & 132+/- & 23 \\ \mathrm{Mg}-\mathrm{K} & 0.00367+/-0.00080 & 170+/- & 37 \\ \mathrm{AI}-\mathrm{K} & 0.14725+/-0.00321 & 6723+/- & 147 \\ \mathrm{Si}-\mathrm{K} & 0.20660+/-0.00379 & 9208+/- & 169 \\ \mathrm{P}-\mathrm{K} & 0.00246+/-0.00092 & 108+/- & 40 \\ \mathrm{~S}-\mathrm{K} & 0.01037+/-0.00118 & 387+/- & 44 \\ \mathrm{Cl}-\mathrm{K} & 0.00702+/-0.00120 & 223+/- & 38 \\ \mathrm{~K}-\mathrm{K} & 0.02618+/-0.00172 & 669+/- & 44 \\ \mathrm{Ca}-\mathrm{K} & 0.16853+/-0.00323 & 3758+/- & 72 \\ \mathrm{Fe}-\mathrm{K} & 0.13944+/-0.01091 & 1151+/- & 90 \\ \mathrm{Ba}-\mathrm{L} & 0.00285+/-0.00452 & 36+/- & 57 \\ \mathrm{TI}-\mathrm{K} & 0.00129+/-0.00228 & 21+/- & 37 \\ \mathrm{O}-\mathrm{K} & 0.13574+/-0.00222 & 2992+/- & 49 \\ \mathrm{C}-\mathrm{K} & 0.13523+/-0.00320 & 2323+/- & 55 \\ \mathrm{~Pb}-\mathrm{M} & 0.01041+/-0.00414 & 195+/- & 78\end{array}$

Adjustment Factors

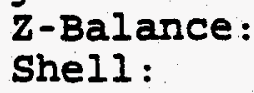

Shell:

$\mathrm{K}$
0.00000
1.00000

$\stackrel{\text { I }}{0.00000}$

$M$

1.00000

0.00000

1.00000

ZAF Correction Acc.Volt. $=15 \mathrm{kV}$ Take-off Angle $=43.31 \mathrm{deg}$ Number of Iterations $=7$

\begin{tabular}{|c|c|c|c|c|c|c|}
\hline $\begin{array}{l}\text { Element } \\
\text { Na-K } \\
\text { Mg-K } \\
\mathrm{AI}-\mathrm{K} \\
\mathrm{Si}-\mathrm{K} \\
\mathrm{P}-\mathrm{K} \\
\mathrm{S}-\mathrm{K} \\
\mathrm{Cl}-\mathrm{K} \\
\mathrm{K}-\mathrm{K} \\
\mathrm{Ca}-\mathrm{K} \\
\mathrm{Fe}-\mathrm{K} \\
\mathrm{Ba}-\mathrm{L} \\
\mathrm{T} \mathrm{i}-\mathrm{K} \\
\mathrm{O}-\mathrm{K} \\
\mathrm{C}-\mathrm{K} \\
\mathrm{Pb}-\mathrm{M} \\
\text { Total }\end{array}$ & $\begin{array}{l}\text { k-ratio } \\
\text { (calc.) } \\
0.0016 \\
0.0019 \\
0.0775 \\
0.1088 \\
0.0013 \\
0.0055 \\
0.0037 \\
0.0138 \\
0.0887 \\
0.0734 \\
0.0015 \\
0.0007 \\
0.0715 \\
0.0712 \\
0.0055\end{array}$ & $\begin{array}{l}1.923 \\
1.494 \\
1.340 \\
1.284 \\
1.342 \\
1.205 \\
1.202 \\
1.111 \\
1.085 \\
1.173 \\
1.377 \\
1.184 \\
3.500 \\
3.919 \\
1.443\end{array}$ & $\begin{array}{r}\text { Atom } \\
0.25 \\
0.23 \\
7.30 \\
9.43 \\
0.11 \\
0.39 \\
0.24 \\
0.74 \\
4.56 \\
2.93 \\
0.03 \\
0.03 \\
29.65 \\
44.06 \\
0.07 \\
100.00\end{array}$ & $\begin{array}{c}\text { Element } \\
\text { Wt } \\
0.30 \\
0.29 \\
10.39 \\
13.97 \\
0.17 \\
0.66 \\
0.44 \\
1.53 \\
9.63 \\
8.62 \\
0.21 \\
0.08 \\
25.02 \\
27.91 \\
0.79 \\
100.00\end{array}$ & $\begin{array}{l}\text { Wt Err. } \\
\text { (1-Sigma) } \\
+/-0.05 \\
+/-0.06 \\
+/-0.23 \\
+/-0.26 \\
+/-0.07 \\
+/-0.08 \\
+/-0.08 \\
+/-0.10 \\
+/-0.18 \\
+/-0.67 \\
+/-0.33 \\
+/-0.14 \\
+/-0.41 \\
+/-0.66 \\
+/-0.31\end{array}$ & $\begin{array}{c}\text { No. of } \\
\text { Cations } \\
0.200 \\
0.182 \\
5.912 \\
7.632 \\
0.086 \\
0.315 \\
0.192 \\
0.601 \\
3.687 \\
2.368 \\
0.023 \\
0.026 \\
-.- \\
35.663 \\
0.059 \\
56.947\end{array}$ \\
\hline
\end{tabular}

The number of cation results are based upon 24 oxygen atoms 
980426.2 .1

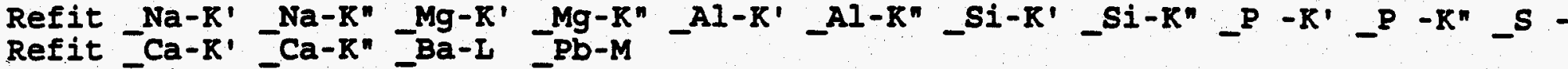

Filter Fit Method

Chi-sgd $=1.36 \quad$ Livetime $=30.0 \mathrm{sec}$.

Standardless Analysis

Element

Relative

Error

k-ratio

(1-Sigma)

Na-K

$0.00006+/-0.00025$

$\mathrm{Mg}-\mathrm{K}$

$0.00021+1-0.00024$

$A I-K$

$0.00018+/-0.00026$

Si-K

$0.00064+1-0.00031$

$\mathrm{P}-\mathrm{K}$

$0.00034+/-0.00043$

$S-K$

$0.00389+/-0.00063$

Cl-K

$0.00202+/-0.00078$

$\mathrm{K}-\mathrm{K}$

$0.01138+/-0.00145$

$\mathrm{Ca}-\mathrm{K}$

$0.36847+/-0.00483$

$\mathrm{Fe}-\mathrm{K}$

$0.43833+/-0.01680$

$\mathrm{Ba}-\mathrm{L}$

$0.00000+/-0.00001$

Ti-K

$0.00236+/-0.00190$

$0-K$

$0.00309+/-0.00067$

C. $-\mathrm{K}$

$0.16903+/-0.00310$

$\mathrm{Pb}-\mathrm{M}$

$0.00000+1-0.00001$

Adjustment Factors

z-Balance:

Shell:

$\mathrm{K}$
0.00000
1.00000

Net

counts (1-Sigma)

$3+1-\quad 13$

$8+1-\quad 9$

$7+/-\quad 11$

$24+1-\quad 11$

$13+/-\quad 16$

$118+/-\quad 19$

$52+/-\quad 20$

$236+/-30$

$6642+/-\quad 87$

$2923+/-\quad 112$

$0+1-\quad 0$

$31+/-\quad 25$

$56+/-\quad 12$

$2348+/-\quad 43$

$0+1-\quad 0$

ZAF Correction Acc.Volt. $=15 \mathrm{kV}$ Take-off Angle $=43.31 \mathrm{deg}$ Number of Iterations $=5$

\begin{tabular}{|c|c|c|c|c|c|c|}
\hline $\begin{array}{l}\mathrm{Na}-\mathrm{K} \\
\mathrm{Mg}-\mathrm{K} \\
\mathrm{Al}-\mathrm{K} \\
\mathrm{S} \mathrm{I}-\mathrm{K} \\
\mathrm{P}-\mathrm{K} \\
\mathrm{S}-\mathrm{K} \\
\mathrm{Cl}-\mathrm{K} \\
\mathrm{K}-\mathrm{K} \\
\mathrm{Ca}-\mathrm{K} \\
\mathrm{Fe}-\mathrm{K} \\
\mathrm{Ba}-\mathrm{L} \\
\mathrm{T} \dot{I}-\mathrm{K} \\
\mathrm{O}-\mathrm{K} \\
\mathrm{C}-\mathrm{K} \\
\mathrm{Pb}-\mathrm{M} \\
\mathrm{TOtal}\end{array}$ & $\begin{array}{l}\text { k-ratio } \\
\text { (calc.) } \\
0.0000 \\
0.0002 \\
0.0001 \\
0.0005 \\
0.0003 \\
0.0031 \\
0.0016 \\
0.0090 \\
0.2931 \\
0.3487 \\
0.0000 \\
0.0019 \\
0.0025 \\
0.1345 \\
0.0000\end{array}$ & $\begin{array}{l}2.585 \\
1.871 \\
1.566 \\
1.306 \\
1.220 \\
1.103 \\
1.095 \\
0.994 \\
1.008 \\
1.124 \\
1.318 \\
1.139 \\
4.342 \\
2.115 \\
1.314\end{array}$ & $\begin{array}{r}0.01 \\
0.03 \\
0.02 \\
0.06 \\
0.03 \\
0.27 \\
0.13 \\
0.59 \\
18.79 \\
17.89 \\
0.00 \\
0.11 \\
1.70 \\
60.37 \\
0.00 \\
100.00\end{array}$ & $\begin{array}{c}\text { Element } \\
\text { wt } t \\
0.01 \\
0.03 \\
0.02 \\
0.07 \\
0.03 \\
0.34 \\
0.18 \\
0.90 \\
29.53 \\
39.17 \\
0.00 \\
0.21 \\
1.07 \\
28.43 \\
0.00 \\
100.00\end{array}$ & $\begin{array}{l}\text { Wt \& Err. } \\
\text { (1-sigma) } \\
+/-0.05 \\
+/-0.04 \\
+/-0.03 \\
+/-0.03 \\
+/-0.04 \\
+/-0.06 \\
+/-0.07 \\
+/-0.11 \\
+/-0.39 \\
+/-1.50 \\
+/-0.00 \\
+/-0.1-1-0.23 \\
+/-0.52 \\
+/-0.52 \\
+/-0.00\end{array}$ & $\begin{array}{r}\text { No. of } \\
\text { Cations } \\
0.180 \\
0.474 \\
0.300 \\
0.851 \\
0.386 \\
3.832 \\
1.791 \\
8.282 \\
265.372 \\
252.646 \\
0.000 \\
7.608 \\
-.-5 \\
852.661 \\
0.000 \\
1388.383\end{array}$ \\
\hline
\end{tabular}

The number of cation results are based upon 24 oxygen atoms 


\section{2 .2}

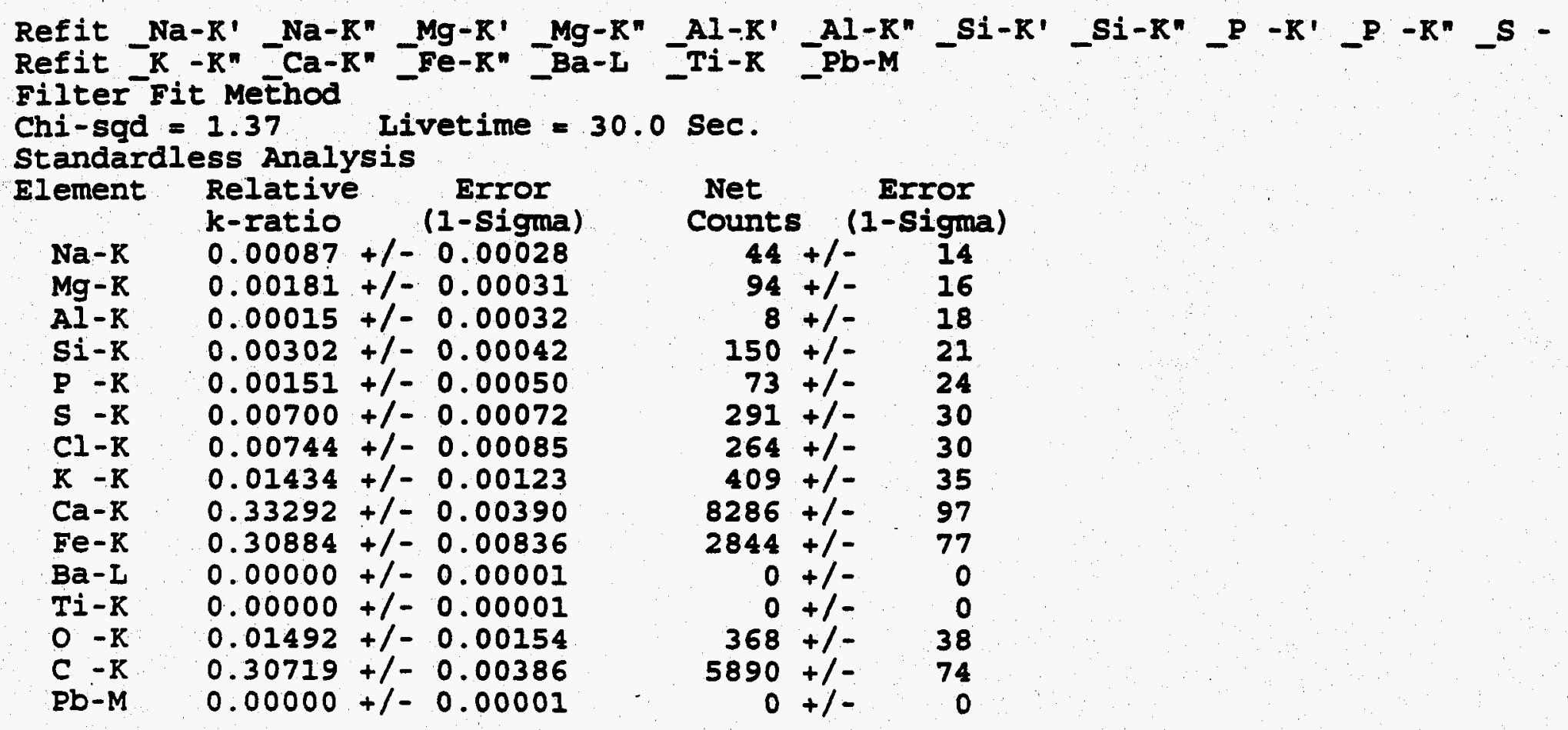

$\begin{array}{cc}\text { Adjustment Factors } & \mathrm{K} \\ \text { Z-Balance: } & 0.00000 \\ \text { Shell: } & 1.00000\end{array}$

I

0.00000

$M$

0.00000

$1.00000 \quad 1.00000$

ZAF Correction Acc.Volt.= $15 \mathrm{kV}$ Take-off Angle $=43.31 \mathrm{deg}$ Number of Iterations $=5$

\begin{tabular}{|c|c|c|c|c|c|c|}
\hline $\begin{array}{l}N a-K \\
M g-K \\
A I-K \\
S i-K \\
P-K \\
S-K \\
C l-K \\
K-K \\
C a-K \\
F e-K \\
B a-I \\
T i-K \\
O-K \\
C-K \\
\text { Pb-M } \\
\text { Total }\end{array}$ & $\begin{array}{c}\text { k-ratio } \\
\text { (calc.) } \\
0.0006 \\
0.0013 \\
0.0001 \\
0.0021 \\
0.0011 \\
0.0049 \\
0.0052 \\
0.0101 \\
0.2339 \\
0.2169 \\
0.0000 \\
0.0000 \\
0.0105 \\
0.2158 \\
0.0000\end{array}$ & $\begin{array}{l}2.357 \\
1.742 \\
1.491 \\
1.266 \\
1.203 \\
1.100 \\
1.104 \\
1.017 \\
1.035 \\
1.159 \\
1.355 \\
1.166 \\
4.878 \\
1.975 \\
1.315\end{array}$ & $\begin{array}{r}0.13 \\
0.18 \\
0.01 \\
0.19 \\
0.08 \\
0.34 \\
0.32 \\
0.52 \\
12.05 \\
8.98 \\
0.00 \\
0.00 \\
6.38 \\
70.81 \\
0.00 \\
100.00\end{array}$ & $\begin{array}{c}\text { Element } \\
\text { Wt } \\
0.14 \\
0.22 \\
0.02 \\
0.27 \\
0.13 \\
0.54 \\
0.58 \\
1.02 \\
24.21 \\
25.14 \\
0.00 \\
0.00 \\
5.11 \\
42.62 \\
0.00 \\
100.00\end{array}$ & $\begin{array}{l}\text { Wt Err } \\
\text { (1-Sigma) } \\
+/-0.05 \\
+/-0.04 \\
+/-0.03 \\
+/-0.04 \\
+/-0.04 \\
+/-0.06 \\
+/-0.07 \\
+/-0.09 \\
+/-0.28 \\
+/-0.68 \\
+/-0.00 \\
+/-0.00 \\
+/-0.53 \\
+/-0.54 \\
+/-0.00\end{array}$ & $\begin{array}{r}\text { No. of } \\
\text { Cations } \\
0.471 \\
0.685 \\
0.044 \\
0.717 \\
0.309 \\
1.268 \\
1.223 \\
1.968 \\
45.374 \\
33.817 \\
0.000 \\
0.000 \\
-.- \\
266.589 \\
0.000 \\
352.466\end{array}$ \\
\hline
\end{tabular}

The number of cation results are based upon 24 oxygen atoms 
980426.2 .3

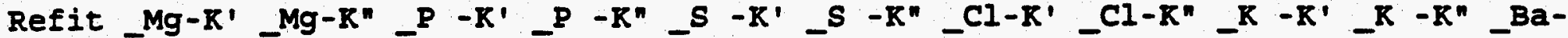
Refit AI-K" "Ca-K' -Ba-I

Filter Fit MeĒhod

Chi-sqd $=3.55 \quad$ Livetime $=30.0 \mathrm{sec}$.

Standardless Analysis

\begin{tabular}{|c|c|c|c|c|}
\hline $\begin{array}{l}\mathrm{Na}-\mathrm{K} \\
\mathrm{Mg}-\mathrm{K} \\
\mathrm{Al}-\mathrm{K} \\
\mathrm{Si}-\mathrm{K} \\
\mathrm{P}-\mathrm{K} \\
\mathrm{S}-\mathrm{K} \\
\mathrm{Cl}-\mathrm{K} \\
\mathrm{K}-\mathrm{K} \\
\mathrm{C} a-\mathrm{K} \\
\mathrm{Fe}-\mathrm{K} \\
\mathrm{B} \mathrm{I}-\mathrm{I} \\
\mathrm{T} \mathrm{I}-\mathrm{K} \\
\mathrm{O}-\mathrm{K} \\
\mathrm{C}-\mathrm{K} \\
\mathrm{Pb}-\mathrm{M}\end{array}$ & $\begin{array}{l}\text { Relative } \\
\text { k-ratio } \\
0.06933 \\
0.00206 \\
0.03062 \\
0.15720 \\
0.00098 \\
0.00547 \\
0.00648 \\
0.00128 \\
0.14130 \\
0.22287 \\
0.00000 \\
0.00020 \\
0.29408 \\
0.06502 \\
0.00311\end{array}$ & $\begin{array}{l}\text { Error } \\
\text { (1-Sigma) } \\
+/-0.00116 \\
+/-0.00060 \\
+/-0.00069 \\
+/-0.00188 \\
+/-0.00056 \\
+/-0.00064 \\
+/-0.00065 \\
+/-0.00068 \\
+/-0.00291 \\
+/-0.00666 \\
+/-0.00001 \\
+/-0.00086 \\
+/-0.00305 \\
+/-0.00178 \\
+/-0.00225\end{array}$ & $\begin{array}{r}\text { Net } \\
\text { Counts } \\
7714 \\
239 \\
3515 \\
17614 \\
107 \\
513 \\
519 \\
82 \\
7922 \\
4622 \\
0 \\
9 \\
16297 \\
2809 \\
147\end{array}$ & 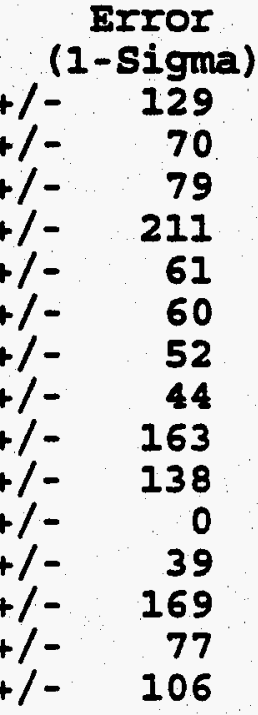 \\
\hline
\end{tabular}

$\begin{array}{lc}\text { Adjustment Factors } & \mathrm{K} \\ \text { Z-Balance: } & 0.00000 \\ \text { Shell: } & 1.00000\end{array}$

$\begin{array}{cc}L & M \\ 0.00000 & 0.00000 \\ 1.00000 & 1.00000\end{array}$

ZAF Correction Acc.Volt. $=15 \mathrm{kV}$ Take-off Angle $=43.31 \mathrm{deg}$ Number of Iterations $=7$

\begin{tabular}{|c|c|c|c|c|c|c|}
\hline $\begin{array}{l}\text { Iement } \\
\text { Na-K } \\
M g-K \\
A I-K \\
S i-K \\
P-K \\
S-K \\
C l-K \\
K-K \\
C a-K \\
F e-K \\
B a-I \\
T i-K \\
O-K \\
C-K \\
\text { Pb-M } \\
\text { Total }\end{array}$ & $\begin{array}{l}\text { k-ratio } \\
\text { (calc.) } \\
0.0388 \\
0.0012 \\
0.0172 \\
0.0881 \\
0.0005 \\
0.0031 \\
0.0036 \\
0.0007 \\
0.0792 \\
0.1249 \\
0.0000 \\
0.0001 \\
0.1648 \\
0.0364 \\
0.0017\end{array}$ & $\begin{array}{l}2.149 \\
1.760 \\
1.500 \\
1.306 \\
1.333 \\
1.195 \\
1.188 \\
1.097 \\
1.066 \\
1.162 \\
1.336 \\
1.158 \\
2.449 \\
3.532 \\
1.431\end{array}$ & $\begin{array}{r}\text { Atom } \\
\\
7.31 \\
0.17 \\
1.92 \\
8.24 \\
0.05 \\
0.23 \\
0.24 \\
0.04 \\
4.24 \\
5.23 \\
0.00 \\
0.01 \\
50.75 \\
21.56 \\
0.02 \\
100.00\end{array}$ & $\begin{array}{c}\text { Element } \\
\text { wt } \\
8.35 \\
0.20 \\
2.57 \\
11.50 \\
0.07 \\
0.37 \\
0.43 \\
0.08 \\
8.44 \\
14.51 \\
0.00 \\
0.01 \\
40.35 \\
12.87 \\
0.25 \\
100.00\end{array}$ & $\begin{array}{l}\text { wt Err. } \\
\text { (1-Sigma) } \\
+/-0.14 \\
+/-0.06 \\
+/-0.06 \\
+/-0.14 \\
+/-0.04 \\
+/-0.04 \\
+/-0.04 \\
+/-0.04 \\
+/-0.17 \\
+/-0.43 \\
+/-0.00 \\
+/-0.06 \\
+/-0.42 \\
+/-0.35 \\
+/-0.18\end{array}$ & $\begin{array}{c}\text { No. of } \\
\text { Cations } \\
3.455 \\
0.080 \\
0.908 \\
3.898 \\
0.022 \\
0.109 \\
0.116 \\
0.019 \\
2.004 \\
2.473 \\
0.000 \\
0.003 \\
--- \\
10.194 \\
0.011 \\
23.292\end{array}$ \\
\hline
\end{tabular}

The number of cation results are based upon 24 oxygen atoms 
Thu May 28 10:30:00 1998

980426.3 .1

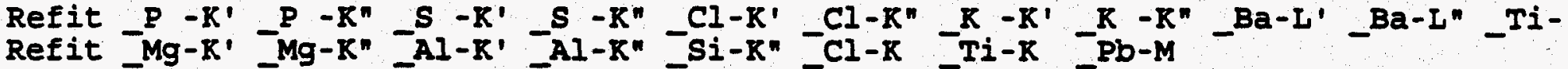

Filter Fit Method

Chi-sqd =5.25 Livetime $=30.0 \mathrm{sec}$

Standardless Analysis

Element.

Relative $\quad$ Error
k-ratio

Net

Counts (1-sigma)

$\mathrm{Na}-\mathrm{K}$

$0.01051+1-$

0.00075

$\mathrm{Mg}-\mathrm{K}$

$0.00541+1-$

0.00049

AI-K

$0.00588+1-$

0.00050

Si-K

$0.13718+1-$

0.00110

P $-K$

$0.00139+1-$

0.00054

$S-K$

$0.00552+1-$

0.00060

Cl-K

$0.00000+1-$

0.00001

$\mathrm{K}-\mathrm{K}$

$0.00087+1-$

0.00069

$\mathrm{Ca}-\mathrm{K}$

$0.27418+1-$

0.00368

$\mathrm{Fe}-\mathrm{K}$

$0.23256+1-$

0.00682

$\mathrm{Ba}-\mathrm{I}$

$0.00137+1-$

0.00178

Ti-K

$0.00000+1-$

0.00001

$0-K$

$0.21523+1-$

0.00281

C $-K$

$0.10990+1-$

0.00208

$\mathrm{Pb}-\mathrm{M}$

$0.00000+1-$

0.00001

$\begin{array}{rr}1158+/- & 83 \\ 621+/- & 56 \\ 668+/- & 57 \\ 15208+/- & 122 \\ 151+/- & 58 \\ 511+/- & 56 \\ 0+/- & 0 \\ 55+/- & 44 \\ 15209+/- & 204 \\ 4771+/- & 140 \\ 43+/- & 56 \\ 0+/- & 0 \\ 11802+/- & 154 \\ 4697+/- & 89 \\ 0+/- & 0\end{array}$

Adjustment Factors

Z-Balance:

$\mathrm{K}$

Shell:

0.00000

L

0.00000

$M$

1.00000

0.00000

1.00000

ZAF Correction Acc. Volt. =

$15 \mathrm{kV}$

Take-off Angle $=43.31 \mathrm{deg}$ Number of Iterations $=6$

\begin{tabular}{|c|c|c|c|c|c|c|}
\hline $\begin{array}{l}N a-K \\
M g-K \\
A I-K \\
S i-K \\
P-K \\
S-K \\
C l-K \\
K-K \\
C a-K \\
F e-K \\
B a-I \\
T i-K \\
O-K \\
C-K \\
\text { Pb-M } \\
\text { Total }\end{array}$ & $\begin{array}{l}\text { k-ratio } \\
\text { (calc.) } \\
0.0059 \\
0.0031 \\
0.0033 \\
0.0775 \\
0.0008 \\
0.0031 \\
0.0000 \\
0.0005 \\
0.1549 \\
0.1314 \\
0.0008 \\
0.0000 \\
0.1216 \\
0.0621 \\
0.0000\end{array}$ & $\begin{array}{l}\text { ZAF } \\
2.276 \\
1.716 \\
1.478 \\
1.269 \\
1.291 \\
1.166 \\
1.154 \\
1.068 \\
1.058 \\
1.168 \\
1.366 \\
1.171 \\
3.102 \\
2.854 \\
1.402\end{array}$ & $\begin{array}{r}1.18 \\
0.43 \\
0.37 \\
7.03 \\
0.07 \\
0.23 \\
0.00 \\
0.03 \\
8.21 \\
5.52 \\
0.02 \\
0.00 \\
47.32 \\
29.61 \\
0.00 \\
100.00\end{array}$ & $\begin{array}{c}\text { Element } \\
\text { Wt } \\
1.35 \\
0.52 \\
0.49 \\
9.83 \\
0.10 \\
0.36 \\
0.00 \\
0.05 \\
16.39 \\
15.35 \\
0.11 \\
0.00 \\
37.72 \\
17.72 \\
0.00 \\
100.00\end{array}$ & $\begin{array}{l}\text { Wt Err. } \\
\text { (1-Sigma) } \\
+/-0.10 \\
+/-0.05 \\
+/-0.04 \\
+/-0.08 \\
+/-0.04 \\
+/-0.04 \\
+/-0.00 \\
+/-0.04 \\
+/-0.22 \\
+/-0.45 \\
+/-0.14 \\
+/-0.00 \\
+/-0.49 \\
+/-0.34 \\
+/-0.00\end{array}$ & $\begin{array}{c}\text { No. of } \\
\text { Cations } \\
0.598 \\
0.220 \\
0.185 \\
3.564 \\
0.033 \\
0.115 \\
0.000 \\
0.014 \\
4.162 \\
2.798 \\
0.008 \\
0.000 \\
-.-1 \\
15.016 \\
0.000 \\
26.715\end{array}$ \\
\hline
\end{tabular}

The number of cation results are based upon 24 oxygen atoms 
Thu May $28 \quad 10: 31: 361998$

980426.3 .2

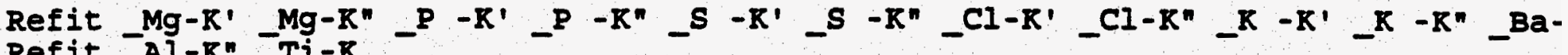
Refit AI-K" TíR

Filter Fit MeÉhod

Chi-sqd $=1.41 \quad$ Livetime $=30.0 \mathrm{sec}$.

Standardless Analysis

Element

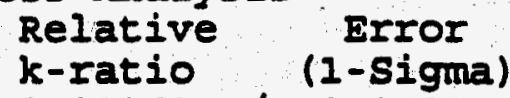

$\mathrm{Na}-\mathrm{K} \quad 0.02261+/-0.00090$

$\mathrm{Mg}-\mathrm{K} \quad 0.00444+/-0.00057$

AI $-\mathrm{K} \quad 0.02059+/-0.00064$

Si-K $\quad 0.13271+/-0.00183$

$P-K \quad 0.00246+/-0.00059$

S $-\mathbb{K} \quad 0.01982+/-0.00080$

Cl-K $\quad 0.00179+/-0.00061$

$\mathrm{K}-\mathrm{K} \quad 0.00299+/-0.00073$

$\mathrm{Ca}-\mathrm{K} \quad 0.31310+/-0.00406$

$\mathrm{Fe}-\mathrm{K}$

$0.10204+/-0.00568$

$\mathrm{Ba}-\mathrm{L}$

$0.00120+/-0.00179$

Ti-K

$0.00000+1-0.00001$

O $-K$

$0.21200+/-0.00283$

$C-K$

$0.15643+/-0.00250$

$\mathrm{Pb}-\mathrm{M}$

$0.00783+/-0.00272$

$\begin{array}{rr}\text { Net } & \text { Error } \\ \text { Counts } & \text { (1-Sigma) } \\ 2309+/- & 92 \\ 472+/- & 61 \\ 2169+/- & 68 \\ 13642+/- & 188 \\ 246+/- & 59 \\ 1703+/- & 69 \\ 132+/- & 45 \\ 176+/- & 43 \\ 16103+/- & 209 \\ 1941+/- & 108 \\ 35+/- & 52 \\ 0+/- & 0 \\ 10778+/- & 144 \\ 6199+/- & 99 \\ 339+/- & 118\end{array}$

Adjustment Factors

z-Balance:

Shell:

$\mathrm{K}$
0.00000
1.00000

I

0.00000

$M$

0.00000

$1.00000 \quad 1.00000$

ZAF Correction Acc.Volt. $=15 \mathrm{kV}$ Take-off Angle $=43.31 \mathrm{deg}$ Number of Iterations $=6$

\begin{tabular}{|c|c|c|c|c|c|c|}
\hline $\begin{array}{l}N a-K \\
M g-K \\
A I-K \\
S i-K \\
P-K \\
S-K \\
C l-K \\
K-K \\
C a-K \\
F e-K \\
B a-I \\
T i-K \\
O-K \\
C-K \\
P b-M \\
\text { Total }\end{array}$ & $\begin{array}{c}\text { k-ratio } \\
\text { (calc.) } \\
0.0117 \\
0.0023 \\
0.0107 \\
0.0689 \\
0.0013 \\
0.0103 \\
0.0009 \\
0.0015 \\
0.1625 \\
0.0530 \\
0.0006 \\
0.0000 \\
0.1100 \\
0.0812 \\
0.0041\end{array}$ & $\begin{array}{l}2.098 \\
1.633 \\
1.425 \\
1.248 \\
1.269 \\
1.155 \\
1.164 \\
1.076 \\
1.073 \\
1.184 \\
1.397 \\
1.208 \\
3.480 \\
2.805 \\
1.386\end{array}$ & $\begin{array}{r}1.99 \\
0.29 \\
1.05 \\
5.69 \\
0.10 \\
0.69 \\
0.06 \\
0.08 \\
8.09 \\
2.09 \\
0.01 \\
0.00 \\
44.53 \\
35.28 \\
0.05 \\
100.00\end{array}$ & $\begin{array}{c}\text { Element } \\
\text { wt t } \\
2.46 \\
0.38 \\
1.52 \\
8.59 \\
0.16 \\
1.19 \\
0.11 \\
0.17 \\
17.43 \\
6.27 \\
0.09 \\
0.00 \\
38.29 \\
22.78 \\
0.56 \\
100.00\end{array}$ & $\begin{array}{l}\text { wt Err. } \\
\text { (1-Sigma) } \\
+/-0.10 \\
+/-0.05 \\
+/-0.05 \\
+/-0.12 \\
+/-0.04 \\
+/-0.05 \\
+/-0.04 \\
+/-0.04 \\
+/-0.23 \\
+/-0.35 \\
+/-0.13 \\
+/-0.00 \\
+/-0.51 \\
+/-0.36 \\
+/-0.20\end{array}$ & $\begin{array}{c}\text { No. of } \\
\text { Cations } \\
1.074 \\
0.155 \\
0.566 \\
3.068 \\
0.052 \\
0.372 \\
0.031 \\
0.043 \\
4.361 \\
1.126 \\
0.006 \\
0.000 \\
-0 . \\
19.016 \\
0.027 \\
29.898\end{array}$ \\
\hline
\end{tabular}

The number of cation results are based upon 24 oxygen atoms 
Thu May $28 \quad 10: 35: 001998$

980426.3 .3

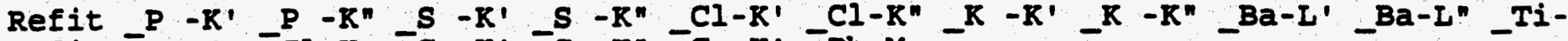

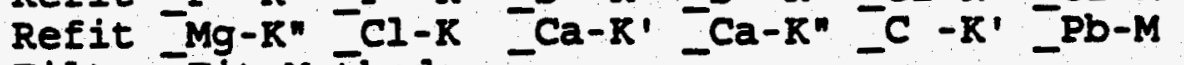
Filter Fit MeĒhod

Chi-sqd $=1.41 \quad$ Iivetime $=30.0 \mathrm{sec}$.

Standardiess Analysis

Element

\section{Relative \\ Error}

k-ratio

Na-K

$\mathrm{Mg}-\mathrm{K}$

$0.01379+1-$

(1-Sigma)

AI $-K$

$0.00815+1-$

0.00088

Si-K

P $-K$

$S-K$

$\mathrm{Cl}-\mathrm{K}$

$0.05160+1-$

$0.19867+1$

$0.00063+1$

0.00068

$+1-$

$0.00000+1-$

$0.00034+1-$

$\mathrm{Ca}-\mathrm{K}$

0.36537

Fe-K

0.14582

$\mathrm{Ba}-\mathrm{I}$

Ti-K

0.00097

$0.00042+1-$

$0.00042+1$

$0.16371+1$

C $-K$

0.04986

0.00000

$+1-$

$\mathrm{Pb}-\mathrm{M}$

Eactors

Adjustment $F$
Z-Balance

Shell:

ZAF Correction Acc.Volt. = $15 \mathrm{kV}$

$\mathrm{R}$

0.00000

1.00000

$\begin{array}{rr}\text { Net } & \text { Error } \\ \text { Counts } & \text { (1-Sigma) } \\ 1347+/- & 86 \\ 828+/- & 76 \\ 5202+/- & 200 \\ 19547+/- & 232 \\ 60+/- & 56 \\ 57+/- & 52 \\ 0+/- & 0 \\ 20+/- & 44 \\ 17987+/- & 144 \\ 2656+/- & 119 \\ 27+/- & 68 \\ 16+/- & 45 \\ 7967+/- & 107 \\ 1891+/- & 53 \\ 0+/- & 0\end{array}$

L

0.00000

1.00000

0.00000

1.00000 Number of Iterations $=5$

\begin{tabular}{|c|c|c|c|c|c|c|}
\hline $\begin{array}{l}\text { lement } \\
\text { Na-K } \\
M g-K \\
\text { AI-K } \\
S i-K \\
P-K \\
S-K \\
C l-K \\
K-K \\
C a-K \\
F e-K \\
B a-I \\
T i-K \\
O-K \\
C-K \\
\text { Pb-M } \\
\text { Total }\end{array}$ & $\begin{array}{l}\text { k-ratio } \\
\text { (calc.) } \\
0.0083 \\
0.0049 \\
0.0309 \\
0.1191 \\
0.0004 \\
0.0004 \\
0.0000 \\
0.0002 \\
0.2190 \\
0.0874 \\
0.0006 \\
0.0003 \\
0.0981 \\
0.0299 \\
0.0000\end{array}$ & $\begin{array}{l}\mathrm{ZAF} \\
2.109 \\
1.624 \\
1.420 \\
1.270 \\
1.333 \\
1.192 \\
1.168 \\
1.042 \\
1.064 \\
1.167 \\
1.391 \\
1.196 \\
3.436 \\
3.512 \\
1.431\end{array}$ & $\begin{array}{r}1.66 \\
0.72 \\
3.57 \\
11.81 \\
0.04 \\
0.03 \\
0.00 \\
0.01 \\
12.75 \\
4.01 \\
0.01 \\
0.01 \\
46.21 \\
19.17 \\
0.00 \\
100.00\end{array}$ & $\begin{array}{c}\text { Element } \\
\text { wt } \\
1.74 \\
0.79 \\
4.39 \\
15.12 \\
0.05 \\
0.05 \\
0.00 \\
0.02 \\
23.30 \\
10.20 \\
0.08 \\
0.03 \\
33.72 \\
10.50 \\
0.00 \\
100.00\end{array}$ & $\begin{array}{l}\text { wt Err } \\
\text { (1-Sigma) } \\
+/-0.11 \\
+/-0.07 \\
+/-0.17 \\
+/-0.18 \\
+/-0.05 \\
+/-0.04 \\
+/-0.00 \\
+/-0.05 \\
+/-0.19 \\
+/-0.46 \\
+/-0.20 \\
+/-0.09 \\
+/-0.45 \\
+/-0.29 \\
+/-0.00\end{array}$ & $\begin{array}{c}\text { No. of } \\
\text { Cations } \\
0.864 \\
0.372 \\
1.854 \\
6.132 \\
0.018 \\
0.017 \\
0.000 \\
0.006 \\
6.621 \\
2.081 \\
0.007 \\
0.007 \\
--5 \\
9.954 \\
0.000 \\
27.933\end{array}$ \\
\hline
\end{tabular}

The number of cation results are based upon 24 oxygen atoms 
Thu May 28 10:37:07 1998

980426.3 .4

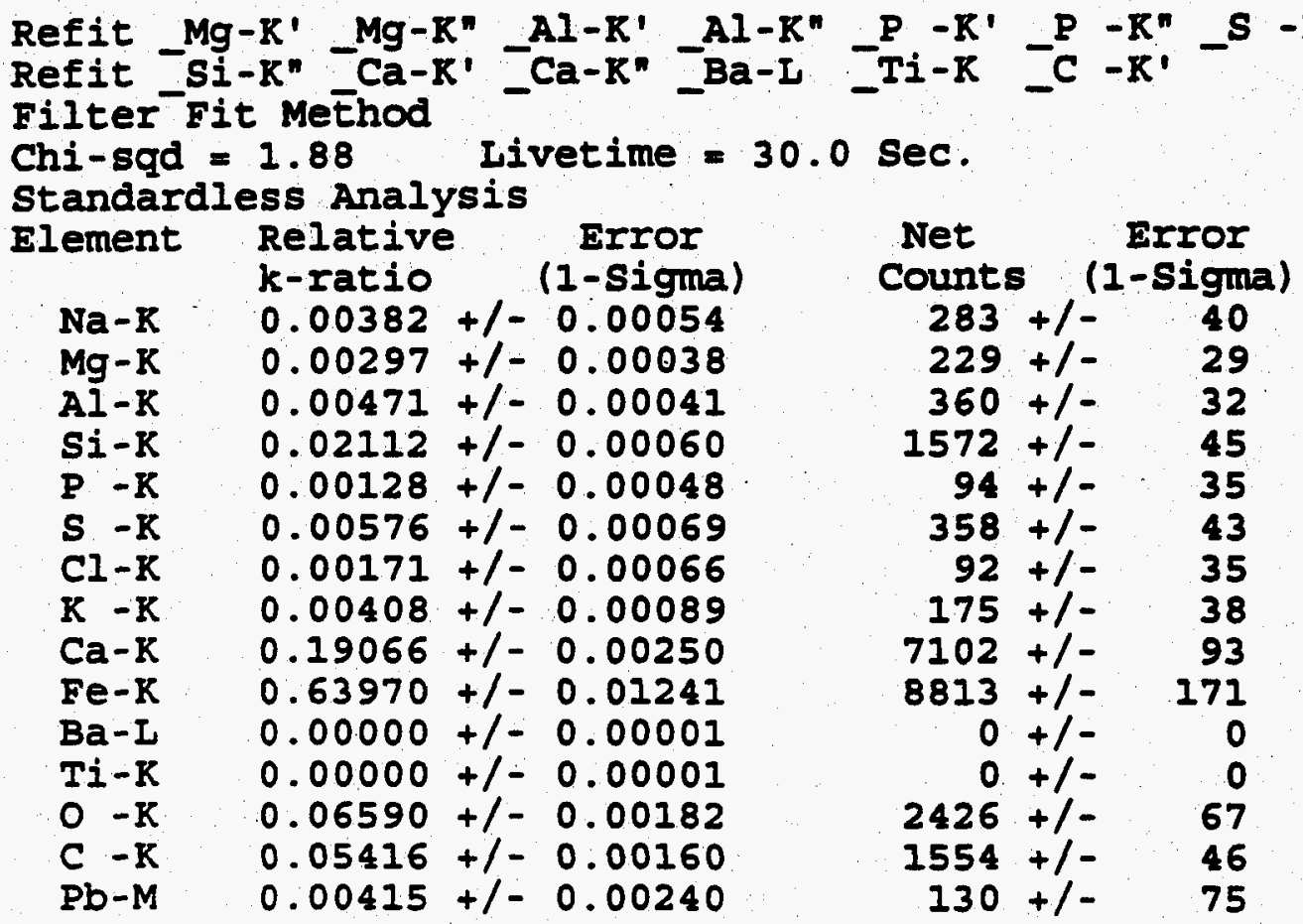

Adjustment Factors

z-Balance:

Shell:

$\begin{array}{ccc}K & I & M \\ 0.00000 & 0.00000 & 0.00000 \\ 1.00000 & 1.00000 & 1.00000\end{array}$

ZAF Correction ACC.Volt. $=15 \mathrm{kV}$ Take-off Angle=43.31 deg Number of Iterations $=5$

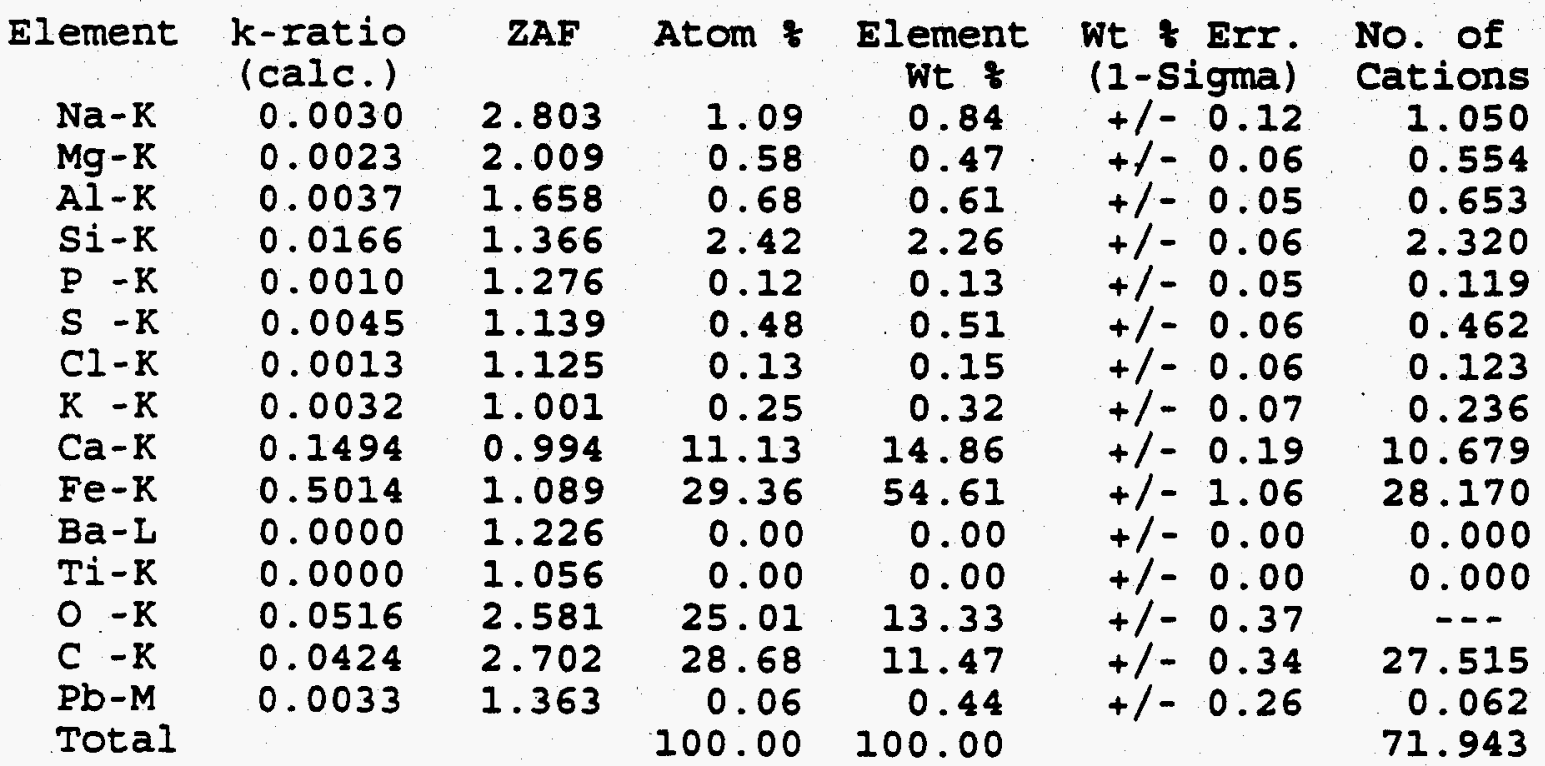

The number of cation results are based upon 24 oxygen atoms 


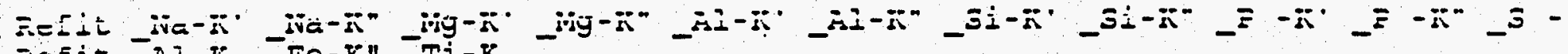
ZEE

\section{Retit - Ba-L}

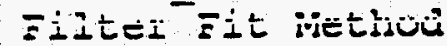

\section{M:i-sod $=2.77$}

Standardiess Analysis

\begin{tabular}{|c|c|c|}
\hline 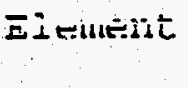 & 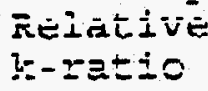 & $\begin{array}{c}\text { EIIOH } \\
\text { (1-Sigma }\end{array}$ \\
\hline$N a-7$ & 0.00020 & .0 .00023 \\
\hline iviy $-\pi$ & 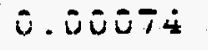 & 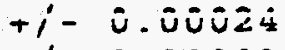 \\
\hline$\therefore \bar{I}-\mathrm{E}$ & 0.00000 & 0.00001 \\
\hline $5 i-F$ & 0.00094 & 0.00025 \\
\hline $\bar{E}-\bar{\pi}$ & 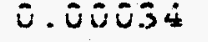 & 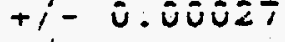 \\
\hline$S-E$ & 0.00058 & 0.00032 \\
\hline$=I-F$ & 0.00050 & 0.00032 \\
\hline$\ddot{r}-\vec{z}$ & $\bar{U} . \bar{U} \bar{U} \bar{\Delta} \dot{4}$ & 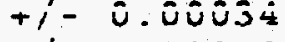 \\
\hline$\Xi \equiv-Z$ & 0.00639 & 0.00048 \\
\hline $\bar{s} \equiv-\bar{Y}$ & 0.01183 & $+7-0.00125$ \\
\hline$\Xi \dot{a}-\bar{L}$ & 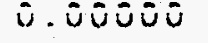 & 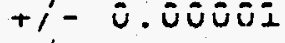 \\
\hline & 0.000 & $+1-0.00001$ \\
\hline$\therefore-5$ & $=0084$ & $+1-0.00108$ \\
\hline$\approx-\pi$ & 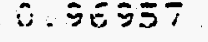 & $+1-\bar{v} . \overline{0} 437$ \\
\hline
\end{tabular}

jojustment Eactors

¿-Ëiaude:

Livezime $=30.0$ sec.

EhะI2:

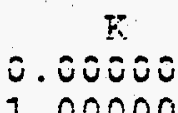

\begin{tabular}{|c|c|c|}
\hline Iที่ & & EN1OO \\
\hline counts & & -Sigm= \\
\hline 27 & +1 & $3 I$ \\
\hline IU்ó & $+i-$ & 34 \\
\hline 0 & $\div 1-$ & 0 \\
\hline 129 & $+1-$ & 35 \\
\hline 45 & $+i-$ & 30 \\
\hline 68 & $\div 1-$ & 35 \\
\hline 59 & $+1-$ & 31 \\
\hline $2 \overline{6}$ & $+i-$ & 200 \\
\hline 441 & $+!-$ & 33 \\
\hline 302 & $+1=$ & 32 \\
\hline$\dot{u}$ & $+i-$ & $\dot{v}$ \\
\hline 0 & $\div 1-$ & 0 \\
\hline 575 & +1 & 73 \\
\hline らしシラこ & $+i-$ & 2.30 \\
\hline
\end{tabular}

I.

0. 00000

$M$

1.00000

0.00000

1.00000

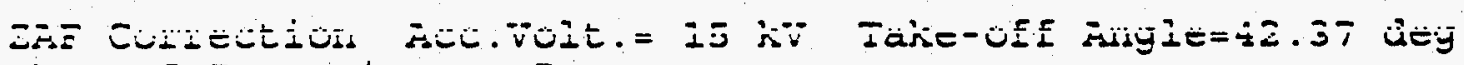

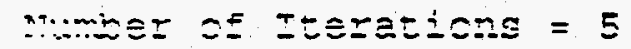

\begin{tabular}{|c|c|c|c|c|c|c|}
\hline Eienibedio & 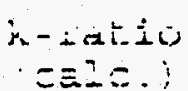 & $\overline{2} \bar{F}$ & 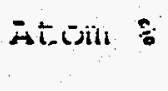 & $\begin{array}{c}\text { Eifutit } \\
n=0\end{array}$ & 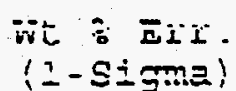 & $\begin{array}{l}\text { ivi. uf } \\
\text { Cations }\end{array}$ \\
\hline 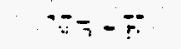 & $\because \quad 5002$ & $1.7 I I$ & 0.02 & 8.03 & $-\therefore-0.03$ & 0.111 \\
\hline$\ddot{M}=-\ddot{x}$ & ค่ . บับธ์ & 1.37 .3 & $\dot{u} \cdot \dot{u} \dot{q}$ & $\bar{u} . \bar{s}$ & $\bar{u} . \bar{u}$ & ن.3is \\
\hline$-\bar{\Sigma}-\because$ & 2.0000 & 2.252 & 0.00 & 0.00 & 0.00 & 0.000 \\
\hline$=\therefore-\ddot{Y}$ & 0908 & 1.142 & $\because \quad 04$ & $0.8 \equiv$ & 0.03 & 0.287 \\
\hline$-\ddot{z}$ & 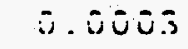 & 1.1.35 & $\bar{u}$ & ن. $\bar{u} . \overline{3}$ & $\bar{u} . \bar{j}$ & 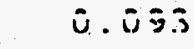 \\
\hline$\equiv-E$ & 2.0005 & 1.083 & 0.02 & 0.25 & 0.03 & 0.248 \\
\hline$\cdots$ & $\therefore 0005$ & I. 121 & 0.02 & $\therefore \quad 56$ & 005 & 0.743 \\
\hline$\because-\ddot{s}$ & 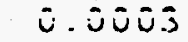 & I. $\mathbf{I} \dot{U} \dot{4}$ & $\bar{u} . \bar{u}$ & i. $3 . \overline{3}$ & $\bar{u} . \bar{U} . \overline{3}$ & $\dot{U} . \overline{4} 7 \bar{j}$ \\
\hline$\therefore \equiv-\therefore$ & 0.0056 & 2.083 & 0.29 & 2.60 & 0.05 & 1.300 \\
\hline$==-r$ & 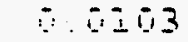 & 1. 226 & 0.28 & $=77$ & 5.13 & 955 \\
\hline$E_{z}-\bar{Z}$ & ส. องดิ & I..367 & $\dot{u} . \hat{U}$ & ด. ถั่ & ט. & $\bar{u} . \bar{u} \bar{u}$ \\
\hline$\because-\because$ & 5.000 & $\div .293$ & 0.00 & $\therefore .00$ & 0.00 & 0.000 \\
\hline$\therefore \quad-\because$ & $\therefore \quad 5-5$ & $=010$ & $\vdots . \pm \overline{3}$ & $\dot{-4} \div$ & $\therefore 57$ & - \\
\hline$=-i$ & $\therefore .8 \div 0$ & $\bar{i} . \bar{I} \bar{j}$ & シラ. シ & 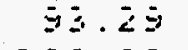 & $+i-i j .4 z$ & 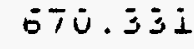 \\
\hline Eこニミ゙- & & & 102.02 & $=20.20$ & & \\
\hline
\end{tabular}

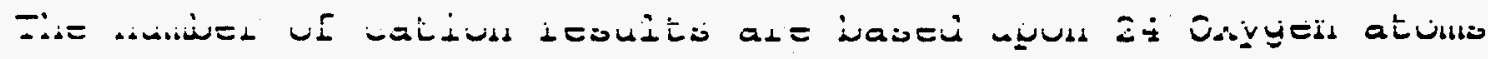




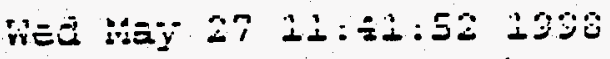

$980 \div 30.1 .2$

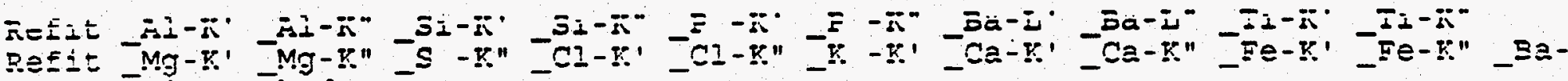
Filter Fit. MeThod

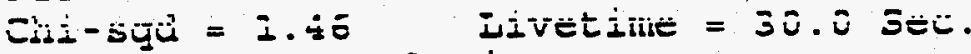

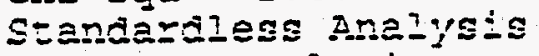

\begin{tabular}{|c|c|c|}
\hline ement. & $\begin{array}{l}\text { Relative } \\
\text { x-ratio }\end{array}$ & $\begin{array}{c}\text { Frror } \\
\text { i.-sigma; }\end{array}$ \\
\hline$N \equiv-Z$ & 0.00848 & $+/-0.00084$ \\
\hline$M g-F$ & 0.01003 & 0.00059 \\
\hline $\bar{i} \bar{I}-\bar{x}$ & 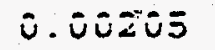 & 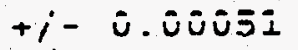 \\
\hline$S \pm-E$ & 0.00823 & 0.00059 \\
\hline$F-E$ & 0.011464 & 0.00066 \\
\hline $5--2$ & ใิ. บิธตรธิ & บิ.ラับエこZ \\
\hline$C I-E$ & 0.01699 & 0.00092 \\
\hline$F-F$ & 0.05739 & $+1-0.00257$ \\
\hline$\overline{E a}-\pi$ & $\dot{U} . \nexists \Sigma 2 \dot{\mathrm{U}}$ & 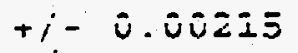 \\
\hline$E \equiv-Z$ & 0.10953 & 0.00395 \\
\hline$E A-I$ & 8.00000 & 0.00001 \\
\hline$\check{i}$ & シ.オンシラォ & 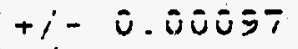 \\
\hline$S-E$ & 0.08443 & 0.00233 \\
\hline-7 & -7666 & 0.00398 \\
\hline
\end{tabular}

\begin{tabular}{|c|c|}
\hline Net. & \\
\hline Conilit: & \\
\hline 735 & $+/-$ \\
\hline 906 & $+1-$ \\
\hline ¿ิ์ & $+i-$ \\
\hline 720 & $\div 1-$ \\
\hline 395 & $+1-$ \\
\hline इบับั & $+i-$ \\
\hline $10 \leq 0$ & $+1-$ \\
\hline 2882 & $+1-$ \\
\hline ธธ์ธะ & $+i-$ \\
\hline 1775 & $\div 1-$ \\
\hline 0 & $+1-$ \\
\hline 31 & $+i-$ \\
\hline 3626 & $+1-$ \\
\hline 15910 & $+1-$ \\
\hline
\end{tabular}

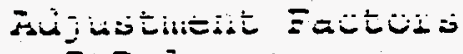
ZーEニIミニニミ:

$\pi$ She: :

0.00000

i

0.00000

$\mathrm{iij}$

1.00000

0.00000

1.00000

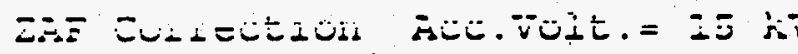

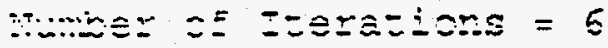

\begin{tabular}{|c|c|c|c|c|c|c|}
\hline 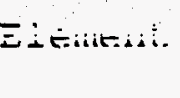 & 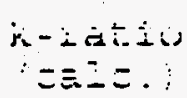 & $\bar{Z} \bar{s} \bar{F}$ & Atoüi : & 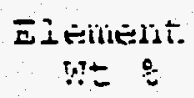 & 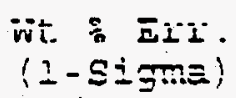 & $\begin{array}{l}\text { Nöo. OE } \\
\text { Cations }\end{array}$ \\
\hline$x=8$ & $\therefore \quad-943$ & 2.006 & $r \Xi \Xi$ & $5 \quad 57$ & $\because-009$ & 0720 \\
\hline$\therefore=-3$ & 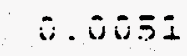 & エ.ララ4 & $\overline{0} .5 i$ & ง. & $\bar{u} \cdot \bar{u}$ & $\bar{U} \cdot \bar{\Delta} \overline{\dot{z}}$ \\
\hline$\therefore=-y$ & 0.0011 & 1.384 & 0.28 & 0.15 & 0.04 & 0.102 \\
\hline$=\div-\because$ & $\therefore \quad-\because \div 2$ & 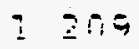 & $\therefore 2 \overline{0}$ & $\therefore \equiv i$ & $9 r 4$ & ก $34=$ \\
\hline $\bar{E}-\ddot{z}$ & 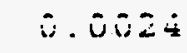 & シンテラ & $\dot{v} . \dot{i} \dot{4}$ & $\overline{\text { i. } .2 \bar{~}}$ & $\bar{u} . \bar{u}$ & シ.エテ \\
\hline$\therefore-\because$ & $\therefore .35$ & 1.008 & 1.80 & $\Xi .96$ & 0.07 & 2.283 \\
\hline$-\cdots$ & $\therefore \quad \therefore=-$ & $i 1+1$ & بذب ب. & $\therefore \quad \bar{\Xi}$ & $0 \quad \overline{1}$ & $0 \equiv 32$ \\
\hline 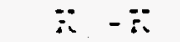 & $\therefore$ ．えこラஷ & エ. กิร & I. $=\hat{\delta}$ & ¿..こi & $\dot{u} . i \dot{q}$ & і.ラรゥ \\
\hline 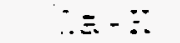 & $\therefore \therefore 700$ & 1.095 & 3.25 & $=. .17$ & 0.22 & 4.007 \\
\hline$=:=-\because$ & $\therefore \quad \because ミ こ Z$ & $I 955$ & $1=8$ & $=7$ & $\therefore \quad-124$ & 2587 \\
\hline$E_{2}-\bar{z}$ & ن. & I. & $\dot{u} . \dot{u} \dot{u}$ & i..$\dot{u} i$ & is.ui & $\dot{u} . \dot{u} \dot{v}$ \\
\hline 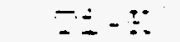 & $\therefore \cos 5$ & 1.195 & $0.2=$ & 0.06 & $0.0 \epsilon$ & 0.221 \\
\hline$-\quad-\because$ & $\therefore \quad \therefore \div$ & $\therefore 675$ & $i 97$ & 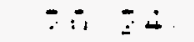 & $\therefore=n$ & $\cdots$ \\
\hline$=-1$ & $\forall .< \pm= \pm$ & $\angle 2 u_{2}$ & $\begin{array}{l}0 y .80 \\
=50\end{array}$ & 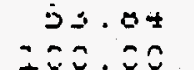 & 0.45 & $\begin{array}{l}\square 5.442 \\
97 . \leq 92\end{array}$ \\
\hline
\end{tabular}

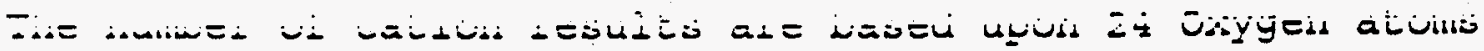




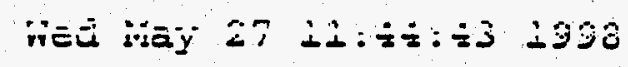

980430.2 .3

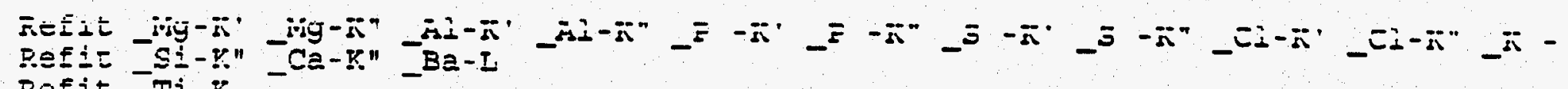
Refit $-T i-k$

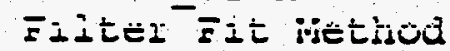

chi-sqd = 11.40 Iivetime $=20.0$ sec.

Standardiess Analysis

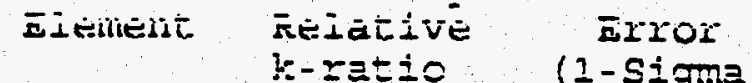

Na-F $\quad 0.01174+1-0.00070$

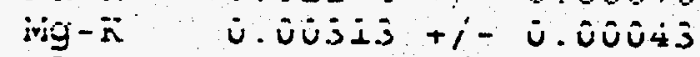

AI-Y $\quad 0.00276+1-0.00041$

Si-K $\quad 0.01057+1-0.00049$

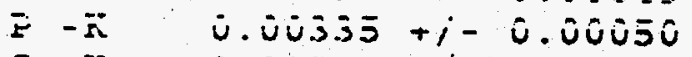

$S-\mathrm{E} \quad 0.00543+1-0.00050$

CI- $\quad 0.00235+1-0.00061$

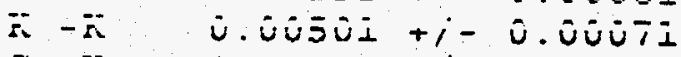

CE-K $\quad 0.04254+/-0.00111$

FE-F $\quad 0.60924+1-0.00899$

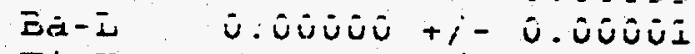

Ti-F $0.00000+1-0.00002$

$0-7 \quad 23080+1-0.00280$

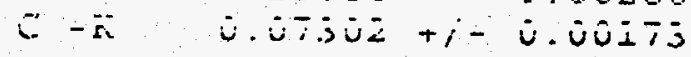

gdiustment Factors

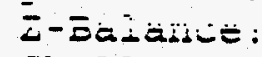

Sho1?:

$K$

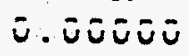

1.00000

\begin{tabular}{|c|c|c|}
\hline $\begin{array}{l}\text { ivet } \\
\text { counts }\end{array}$ & & $\begin{array}{l}\text { Erior } \\
\text { - Sigma }\end{array}$ \\
\hline 1482 & $+1-$ & 88 \\
\hline $4 \pm 2$ & $+i-$ & 57 \\
\hline 361 & $+1-$ & 53 \\
\hline $\begin{array}{r}1344 \\
410\end{array}$ & $+1-$ & 62 \\
\hline $\begin{array}{l}410 \\
577\end{array}$ & $\begin{array}{l}+1- \\
+1-\end{array}$ & $\begin{array}{l}-22 \\
64\end{array}$ \\
\hline 214 & $+1=$ & 55 \\
\hline 307 & $+i-$ & 52 \\
\hline 2711 & $\div / 1-$ & 72 \\
\hline 14362 & $+1-$ & 212 \\
\hline $\bar{u}$ & $+i-$ & $\dot{v}$ \\
\hline 0 & $+1-$ & 0 \\
\hline 14418 & $+1-$ & 175 \\
\hline 3545 & $+i-$ & $\hat{\alpha} \dot{4}$ \\
\hline
\end{tabular}

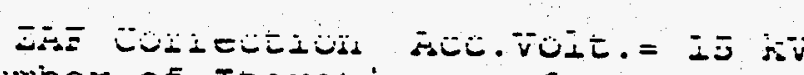

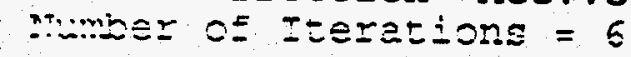

$=$

\begin{tabular}{|c|c|}
\hline EAttr-ia & $\begin{array}{l}x-i d i \\
=I=1\end{array}$ \\
\hline$M$ & a ous \\
\hline$\dot{i}=-\bar{z}$ & u. \\
\hline$\therefore \bar{i}-\bar{z}$ & $\therefore .2: 20$ \\
\hline$= \pm-7$ & $\div .08 \overline{7}$ \\
\hline$z-\bar{z}$ & 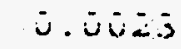 \\
\hline$\Xi-\Xi$ & ล. ละ 20 \\
\hline 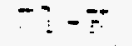 & $\therefore \quad-06$ \\
\hline$\therefore-\pi$ & 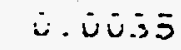 \\
\hline$\therefore \equiv-\square$ & $\therefore .0294$ \\
\hline $\bar{F}=-\bar{r}$ & $\therefore .474$ \\
\hline$\equiv=-\Sigma$ & نं نं \\
\hline$\because 2-\because$ & $\therefore .0000$ \\
\hline$\therefore \quad-=$ & $\therefore \quad \therefore \equiv \equiv$ \\
\hline$=-r$ & $\because .45 \overline{5}$ \\
\hline
\end{tabular}

\begin{tabular}{|c|c|c|}
\hline$\overline{Z A F}$ & Aton & 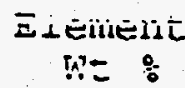 \\
\hline 2.830 & 2.38 & 2.30 \\
\hline 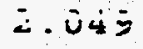 & ن. & $\bar{u} . \dot{q} \dot{q}$ \\
\hline ‥ 686 & 0.28 & 0.32 \\
\hline 1.387 & $0.8 \overline{8}$ & I. OI \\
\hline ‡.2のう & $\bar{u} .2 j$ & $\dot{u} . j \dot{u}$ \\
\hline 2.157 & 0.32 & 0.13 \\
\hline 1.146 & 0.13 & $\therefore \quad i \overline{5}$ \\
\hline 1.050 & $\bar{u} .2 \bar{z}$ & $\dot{0} \ldots i 7$ \\
\hline 1.012 & $2.7 ?$ & $\therefore .98$ \\
\hline 1.113 & 20.00 & 45.89 \\
\hline I. I52 & $\bar{u} \cdot \dot{u} \bar{u}$ & $\bar{u} . \bar{u} \dot{u}$ \\
\hline 1.028 & 2.00 & $\approx .20$ \\
\hline I. $5 \equiv 2$ & 4் & $=I . I T$ \\
\hline 2.692 & $\begin{array}{r}20 . \dot{1} \overline{1} \\
200.00\end{array}$ & $\begin{aligned} & 13.00 \\
&=00.00\end{aligned}$ \\
\hline
\end{tabular}

I.

บ. ปับับั

1.00000

$M$

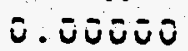

1. 00000

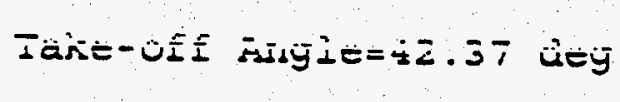




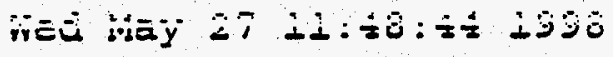

$980 \div 30.1 .4$

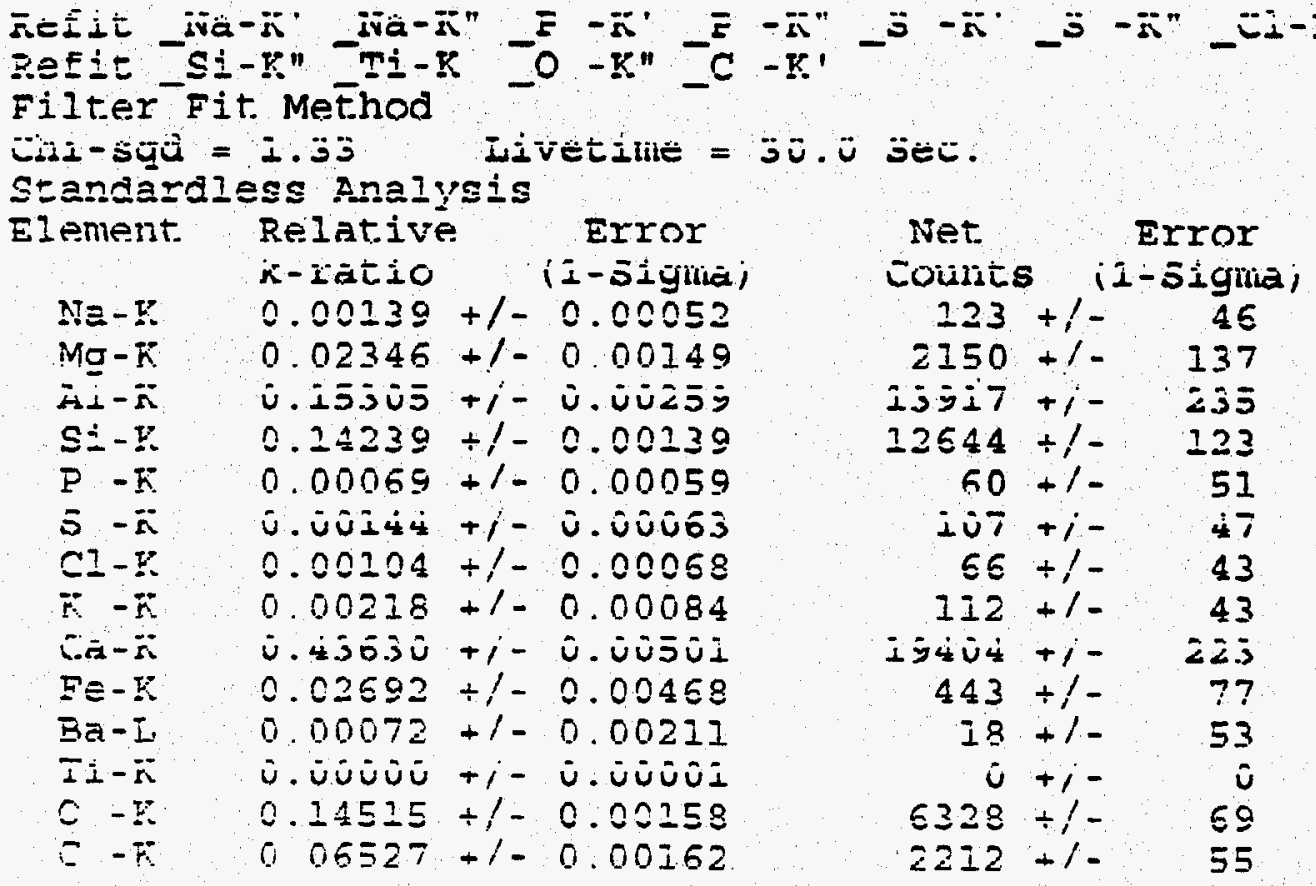

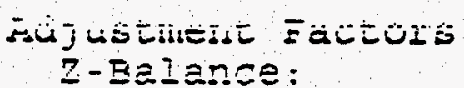

$\pi$
0.00000
1.00000

0.00000
1.00000

ivi

Shei1:

0.00000

1.00000

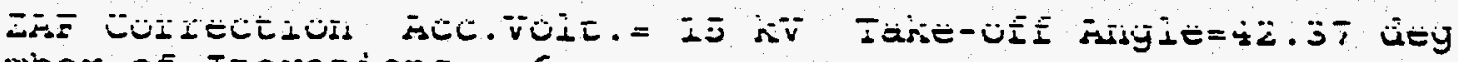

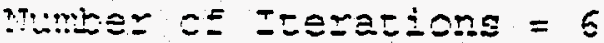

\begin{tabular}{|c|c|c|c|c|c|c|}
\hline E_- & 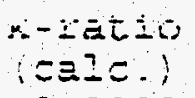 & $\overline{L A} \bar{F}$ & - & $\begin{array}{c}\bar{x}+\mathrm{mis} \\
\mathrm{n}=0\end{array}$ & 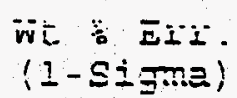 & $\begin{array}{l}\text { ivo. oi } \\
\text { Cations }\end{array}$ \\
\hline $\bar{x}=\bar{r}$ & 0.0008 & 1.953 & 0.14 & $0 \quad I \equiv$ & $\because 006$ & 0079 \\
\hline 等 & $\dot{0} 0334$ & I.5us & i. 74 & $2 . \bar{z}$ & $+1-\quad$ U.j.j & $\bar{u} . \bar{i}$ \\
\hline$\therefore-5$ & 2.0977 & 1.362 & 9.25 & $12.9: 1$ & $+1-0.20$ & 5.285 \\
\hline$=\div-\square$ & 7. 816 & 1.310 & 794 & 1065 & 010 & 4.456 \\
\hline$\Xi-\overline{-}$ & $\therefore .504$ & 1.527 & نَ نَ & $\dot{u} . \bar{L}$ & $\dot{v} \cdot \bar{u}$ & نे نे \\
\hline$\Xi-\because$ & 0.0008 & 1.199 & 0.06 & 2.20 & $0 . \Omega \hat{z}$ & 0.036 \\
\hline$\because-7$ & $\therefore$ - & 1.174 & 0.04 & $\therefore \quad \therefore$ & $\therefore 0.05$ & 0.023 \\
\hline 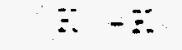 & $\therefore$ 次こ & I. $45 \%$ & ד. & $\therefore . i$ & $+-\dot{u} \cdot \bar{u}$ & $\dot{u} \cdot \dot{u} \dot{u}$ \\
\hline$\Xi \equiv-\because$ & $\therefore .209$ & 1.073 & 13.90 & $2 E .8=$ & 0.31 & 7.238 \\
\hline$==-\ddot{*}$ & $\therefore$ 본 & 1.180 & 065 & I $\bar{z}$ & $\therefore-0.32$ & 0.382 \\
\hline$\equiv=-\overline{-}$ & $\therefore$. & I. $\dot{4}$ ¿ & $\dot{u} . \dot{u}$ & $\dot{U} . \bar{U}$ & $+i-6.17$ & S. نं \\
\hline$\because=-5$ & 2.0000 & 1.234 & 0.00 & 0.20 & 0.00 & 0.000 \\
\hline$\therefore \quad-\because$ & $\because \quad 5=2$ & $3.9 \div 2$ & $4=7=$ & $\Xi \Xi \quad=$ & $+i-836$ & $\ldots$ \\
\hline 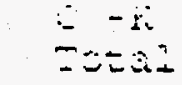 & $\therefore .074$ & 3.577 & $\begin{aligned} & 23.20 \\
= & 00.30\end{aligned}$ & $\begin{array}{rl} & 13.35 \\
2 & 30.08\end{array}$ & $+i-i . s j$ & $\begin{array}{l}\text { is. } 448 \\
32.09: 2\end{array}$ \\
\hline
\end{tabular}

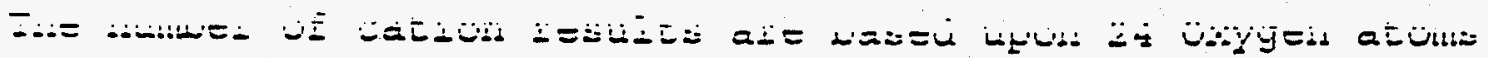


Wis

$580 \div 30.2 .5$

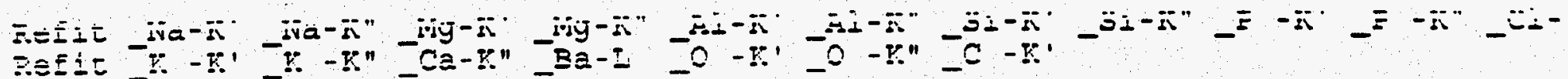
rilter Fit Method

تui-squ= = I.

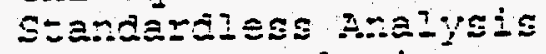

\begin{tabular}{|c|c|c|}
\hline Element & $\begin{array}{l}\text { Reiative } \\
\text { k-iatio }\end{array}$ & $\begin{array}{c}\text { Error } \\
\text { ii-sigma }\end{array}$ \\
\hline$N=-Y$ & 0.00022 & $+1-0.00020$ \\
\hline $\operatorname{ing}-\vec{r}$ & 0.00064 & 0.00023 \\
\hline $\bar{A} \bar{i}-\vec{n}$ & 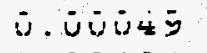 & 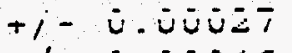 \\
\hline$S:-\mathrm{E}$ & 0.00484 & 0.00046 \\
\hline$P-F$ & 00133 & 0.00059 \\
\hline $5-\pi$ & ¿. $\triangle 2 \Xi 70$ & 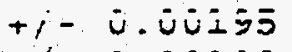 \\
\hline$c 2-z$ & 0.00862 & 0.00108 \\
\hline$F=-5$ & $0 \quad 02535$ & $00016 I$ \\
\hline 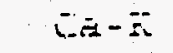 & $\bar{v} .35=36$ & 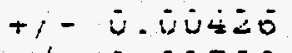 \\
\hline$F \equiv-F$ & $0.5 \equiv 276$ & 0.01580 \\
\hline Ea- & 00000 & 0.00001 \\
\hline$\check{\Sigma}-\bar{r}$ & U. & U. UUंदi \\
\hline $0-Z$ & $0.009 \div ?$ & $0.0006 ?$ \\
\hline$=-\bar{r}$ & 10258 & 0.00135 \\
\hline
\end{tabular}

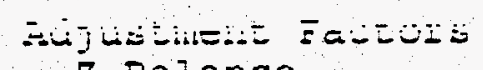

$Z-B \triangleq I \equiv \cap \Omega \cong:$

sheid:

$\begin{array}{lll}0.00000 & 0.00000 & 0.00000 \\ 1.00000 & 1.00000 & 1.00000\end{array}$

Net Error

Loulits (i-sigma)

$10+1-\quad 9$

$30+1-\quad 11$

$2 i+i-$ i.

$221 \div 1-\quad 21$

$60+1-26$

$579+i-74$

$279+1-\quad 35$

$615+1-\quad 42$

$7 \overline{54}+i-\quad \overline{1}$

$4653+1-\quad 133$

$0+1-0$

$4 j+i-\quad j u$

$109 \div 1-\quad 15$

$330+\because-20$

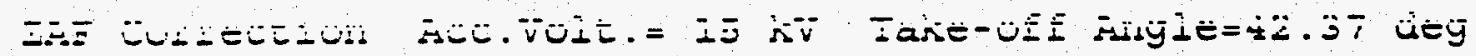

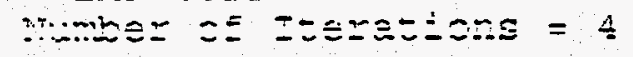

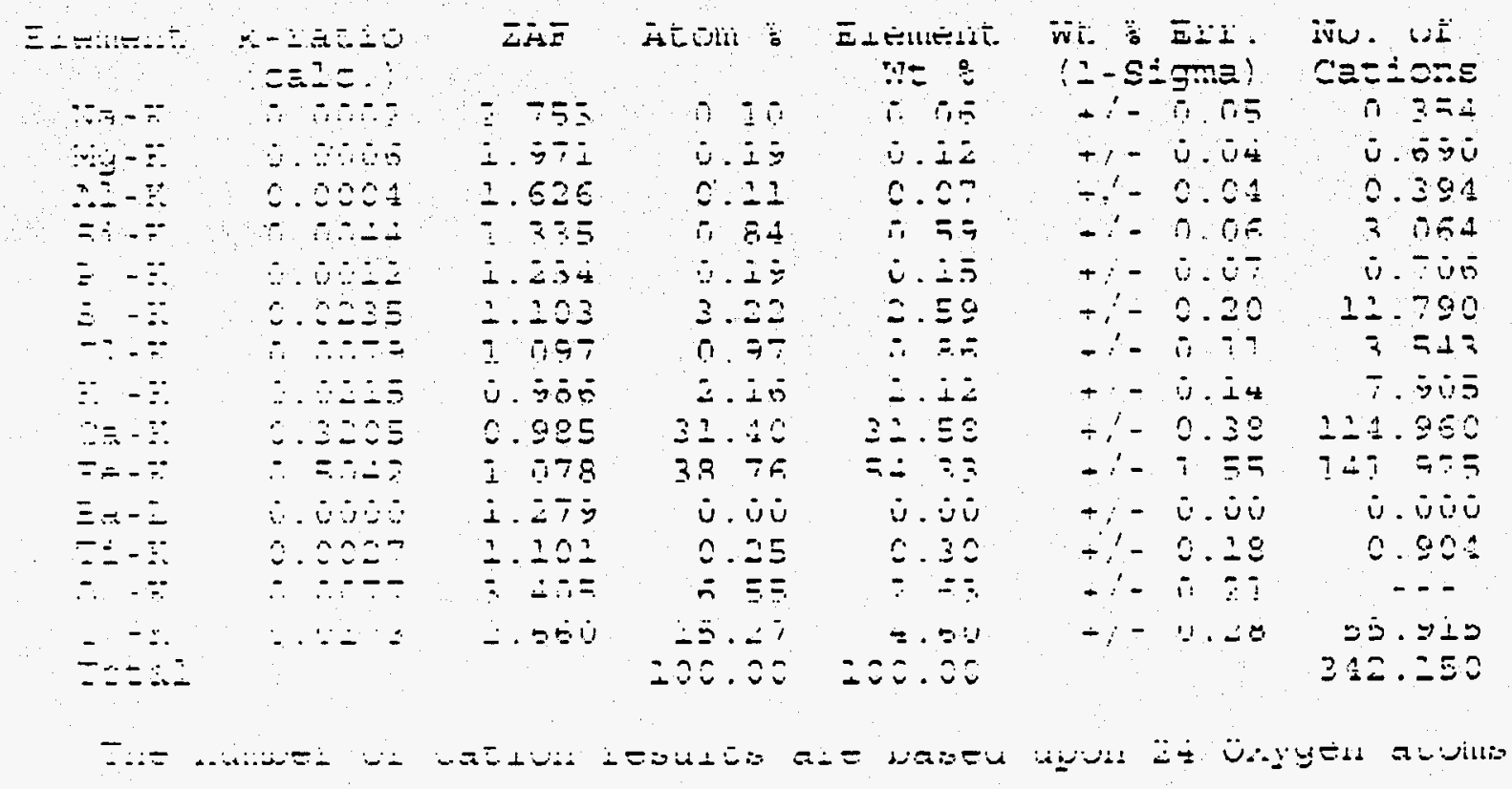


980430.2 .1

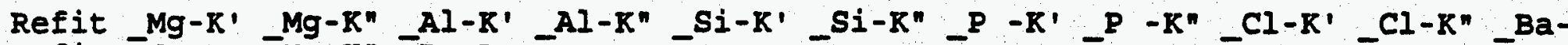
Refit ${ }^{-}-K^{n}-K-K^{n}-B a-L$

Filter Fit Method

Chi-sgd $=1.93 \quad$ Iivetime $=30.0 \mathrm{sec}$.

Standardless Analysis

Element

$\begin{array}{lc}\text { Relative } & \text { Error } \\ k \text {-ratio } & (1-\text { Sigma })\end{array}$

$\mathrm{Na}-\mathrm{K}$

$0.00362+1-$

0.00049

$\mathrm{Mg}-\mathrm{K}$

$0.00231+/-0.00034$

A:I-K

$0.00153+/-0.00035$

Si-K

$0.00543+/-0.00045$

$P-K$

$0.00205+1-0.00050$

$S-K$

$0.02041+/-0.00080$

Cl-K

$0.00409+1-0.00073$

$\mathrm{K}-\mathrm{K}$

$0.02640+/-0.00107$

$\mathrm{Ca}-\mathrm{K}$

$0.06910+1-$

0.00289

Fe-K

$0.70468+1-$

0.01124

$B a-I$

$0.00000+1-$

0.00001

$T i-K$

$0.00011+/-0.00114$

$0-K$

$0.09255+1-$

0.00197

C $-\mathbb{K}$

$0.06771+/-0.00172$

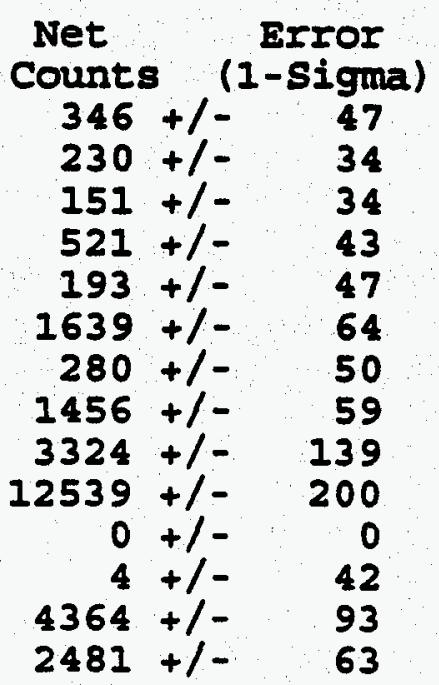

Adjustment Factors

Z-Balance:

Shell:

$\mathrm{K}$
0.00000
1.00000

L

0.00000

$M$

1.00000

0.00000

1.00000

ZAF Correction Acc.Volt. $=15 \mathrm{kV}$ Take-off Angle $=42.37 \mathrm{deg}$ Number of Iterations $=5$

\begin{tabular}{|c|c|c|c|c|c|c|}
\hline $\begin{array}{l}N a-K \\
M g-K \\
A I-K \\
S i-K \\
P-K \\
S-K \\
C l-K \\
K-K \\
C a-K \\
F e-K \\
B a-I \\
T i-K \\
O-K \\
C-K \\
\text { Total }\end{array}$ & $\begin{array}{l}\text { k-ratio } \\
\text { (calc.) } \\
0.0027 \\
0.0018 \\
0.0012 \\
0.0041 \\
0.0016 \\
0.0155 \\
0.0031 \\
0.0200 \\
0.0524 \\
0.5346 \\
0.0000 \\
0.0001 \\
0.0702 \\
0.0514\end{array}$ & $\begin{array}{l}\text { ZAF } \\
2.911 \\
2.069 \\
1.695 \\
1.385 \\
1.277 \\
1.142 \\
1.135 \\
1.039 \\
1.000 \\
1.088 \\
1.183 \\
1.020 \\
2.250 \\
2.814\end{array}$ & $\begin{array}{r}0.98 \\
0.42 \\
0.20 \\
0.57 \\
0.18 \\
1.55 \\
0.28 \\
1.49 \\
3.67 \\
29.21 \\
0.00 \\
0.01 \\
27.70 \\
33.75 \\
100.00\end{array}$ & $\begin{array}{c}\text { Element } \\
\text { Wt } t \\
0.80 \\
0.36 \\
0.20 \\
0.57 \\
0.20 \\
1.77 \\
0.35 \\
2.08 \\
5.24 \\
58.16 \\
0.00 \\
0.01 \\
15.80 \\
14.45 \\
100.00\end{array}$ & $\begin{array}{l}\text { Wt f Err } \\
\text { (1-Sigma) } \\
+/-0.11 \\
+/-0.05 \\
+/-0.04 \\
+/-0.05 \\
+/-0.05 \\
+/-0.07 \\
+/-0.06 \\
+/-0.08 \\
+/-0.22 \\
+/-0.93 \\
+/-0.00 \\
+/-0.09 \\
+/-0.34 \\
+/-0.37\end{array}$ & $\begin{array}{r}\text { No. of } \\
\text { Cations } \\
0.846 \\
0.363 \\
0.177 \\
0.493 \\
0.156 \\
1.340 \\
0.241 \\
1.294 \\
3.178 \\
25.310 \\
0.000 \\
0.004 \\
--1- \\
29.245 \\
62.648\end{array}$ \\
\hline
\end{tabular}

The number of cation results are based upon 24 oxygen atoms 
980430.2 .2

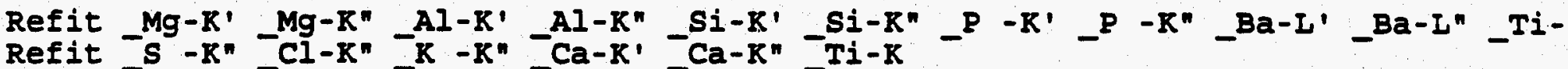
Filter Fit MeẼhod

Chi-sqd $=1.70 \quad$ Livetime $=30.0 \mathrm{sec}$.

Standardless Analysis

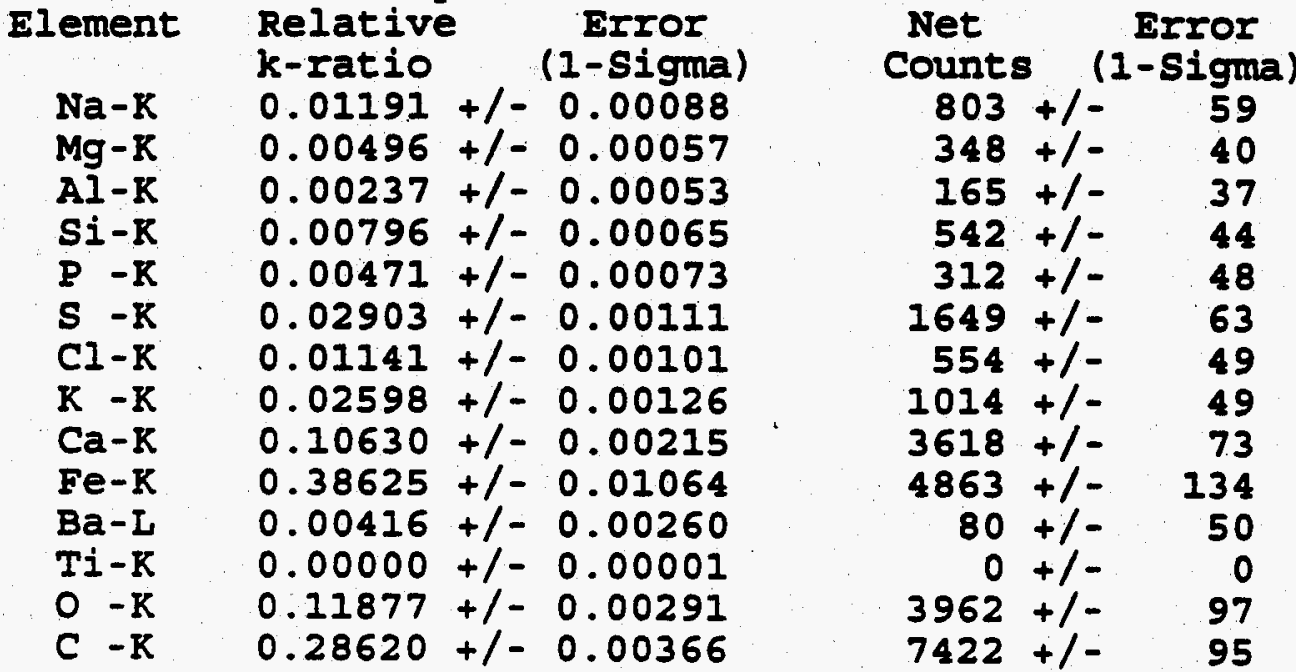

Adjustment Factors

Z-Balance:

Shell:

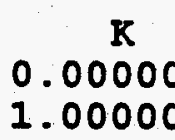

I

0.00000

1.00000
$M$

0.00000

1.00000

ZAF Correction Acc.Volt. $=15 \mathrm{kV}$ Take-off Angle $=42.37 \mathrm{deg}$ Number of Iterations $=6$

\begin{tabular}{|c|c|c|c|c|c|c|}
\hline $\begin{array}{l}N a-K \\
M g-K \\
A I-K \\
S i-K \\
P-K \\
S-K \\
C l-K \\
K-K \\
C a-K \\
F e-K \\
B a-I \\
T i-K \\
O-K \\
C-K \\
\text { Total }\end{array}$ & $\begin{array}{l}\text { k-ratio } \\
\text { (calc.) } \\
0.0067 \\
0.0028 \\
0.0013 \\
0.0045 \\
0.0027 \\
0.0163 \\
0.0064 \\
0.0146 \\
0.0598 \\
0.2173 \\
0.0023 \\
0.0000 \\
0.0668 \\
0.1610\end{array}$ & $\begin{array}{l}2.403 \\
1.796 \\
1.532 \\
1.297 \\
1.232 \\
1.128 \\
1.144 \\
1.075 \\
1.050 \\
1.160 \\
1.313 \\
1.110 \\
3.358 \\
2.384\end{array}$ & $\begin{array}{r}1.28 \\
0.38 \\
0.14 \\
0.38 \\
0.19 \\
1.05 \\
0.38 \\
0.74 \\
2.87 \\
8.27 \\
0.04 \\
0.00 \\
25.70 \\
58.57 \\
100.00\end{array}$ & $\begin{array}{r}\text { Element } \\
\text { wt } \% \\
1.61 \\
0.50 \\
0.20 \\
0.58 \\
0.33 \\
1.84 \\
0.73 \\
1.57 \\
6.28 \\
25.22 \\
0.31 \\
0.00 \\
22.44 \\
38.39 \\
100.00\end{array}$ & $\begin{array}{l}\text { Wt } \text { Err. } \\
\text { (1-sigma) } \\
+/-0.12 \\
+/-0.06 \\
+/-0.05 \\
+/-0.05 \\
+/-0.05 \\
+/-0.07 \\
+/-0.07 \\
+/-0.08 \\
+/-0.13 \\
+/-0.69 \\
+/-0.19 \\
+/-0.00 \\
+/-0.55 \\
+/-0.49\end{array}$ & $\begin{array}{r}\text { No. of } \\
\text { Cations } \\
1.198 \\
0.353 \\
0.129 \\
0.354 \\
0.180 \\
0.983 \\
0.354 \\
0.687 \\
2.680 \\
7.726 \\
0.038 \\
0.000 \\
-.5 \\
54.685 \\
69.370\end{array}$ \\
\hline
\end{tabular}

The number of cation results are based upon 24 oxygen atoms 
Wed May 27 13:49:31 1998

980430.3 .1

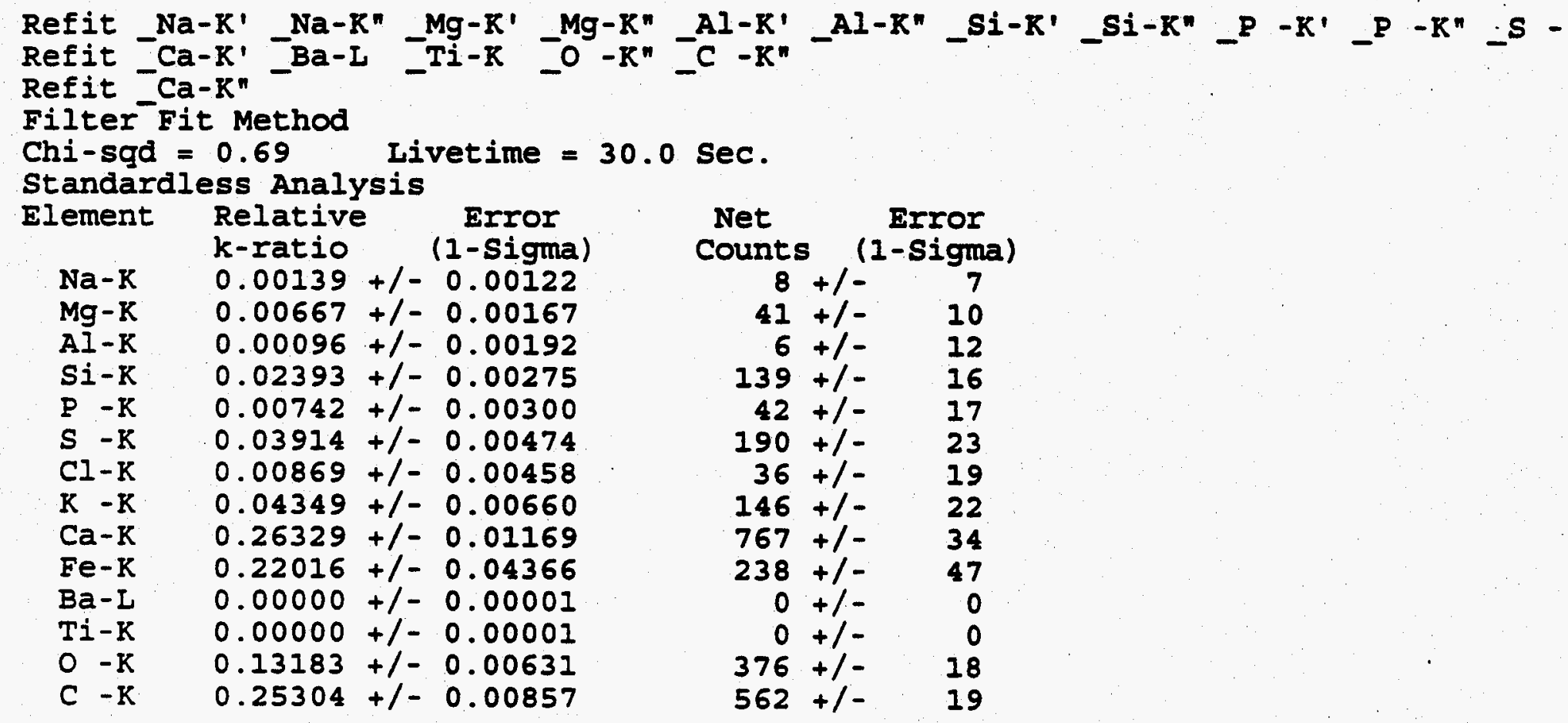

Adjustment Factors

$\begin{array}{ll}\text { Z-Balance: } & 0.00000 \\ \text { Shell: } & 1.00000\end{array}$

$\mathrm{K}$

L

0.00000

$M$

0.00000

$1.00000 \quad 1.00000$

ZAF Correction Acc.Volt. $=15 \mathrm{kV}$ Take-off Angle $=42.37 \mathrm{deg}$ Number of Iterations $=\mathbf{5}$

\begin{tabular}{|c|c|c|c|c|c|c|}
\hline $\begin{array}{l}\text { Element } \\
\begin{array}{l}\mathrm{Na}-\mathrm{K} \\
\mathrm{Mg}-\mathrm{K} \\
\mathrm{AI}-\mathrm{K} \\
\mathrm{S} \mathrm{i}-\mathrm{K} \\
\mathrm{P}-\mathrm{K} \\
\mathrm{S}-\mathrm{K} \\
\mathrm{Cl}-\mathrm{K} \\
\mathrm{K}-\mathrm{K} \\
\mathrm{Ca}-\mathrm{K} \\
\mathrm{Fe}-\mathrm{K} \\
\mathrm{Ba}-\mathrm{L} \\
\mathrm{T} \mathrm{i}-\mathrm{K} \\
O-K \\
\mathrm{C}-\mathrm{K} \\
\text { Total }\end{array}\end{array}$ & $\begin{array}{c}\text { k-ratio } \\
\text { (calc.) } \\
0.0008 \\
0.0037 \\
0.0005 \\
0.0133 \\
0.0041 \\
0.0217 \\
0.0048 \\
0.0241 \\
0.1462 \\
0.1222 \\
0.0000 \\
0.0000 \\
0.0732 \\
0.1405\end{array}$ & $\begin{array}{l}2.274 \\
1.694 \\
1.465 \\
1.256 \\
1.212 \\
1.117 \\
1.136 \\
1.062 \\
1.065 \\
1.177 \\
1.373 \\
1.182 \\
3.928 \\
2.328\end{array}$ & $\begin{array}{r}0.14 \\
0.48 \\
0.05 \\
1.09 \\
0.30 \\
1.39 \\
0.28 \\
1.21 \\
7.15 \\
4.74 \\
0.00 \\
0.00 \\
33.07 \\
50.11 \\
100.00\end{array}$ & $\begin{array}{c}\text { Element } \\
\text { Wt } t \\
0.18 \\
0.63 \\
0.08 \\
1.67 \\
0.50 \\
2.43 \\
0.55 \\
2.56 \\
15.56 \\
14.39 \\
0.00 \\
0.00 \\
28.75 \\
32.71 \\
100.00\end{array}$ & $\begin{array}{l}\text { Wt Err. } \\
\text { (1-Sigma) } \\
+/-0.15 \\
+/-0.16 \\
+/-0.16 \\
+/-0.19 \\
+/-0.20 \\
+/-0.29 \\
+/-0.29 \\
+/-0.39 \\
+/-0.69 \\
+/-2.85 \\
+/-0.00 \\
+/-0.00 \\
+/-1.38 \\
+/-1.11\end{array}$ & $\begin{array}{r}\text { No. of } \\
\text { Cations } \\
0.102 \\
0.345 \\
0.039 \\
0.793 \\
0.215 \\
1.011 \\
0.206 \\
0.876 \\
5.186 \\
3.441 \\
0.000 \\
0.000 \\
-.56 \\
36.369 \\
48.583\end{array}$ \\
\hline
\end{tabular}


Wed May 27 13:53:05 1998

980430.3 .2

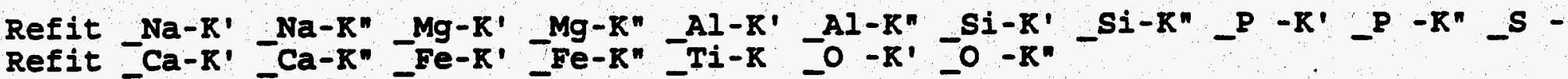
Filter Fit MeĒhod

Chi-sqd $=0.87 \quad$ Livetime $=30.0 \mathrm{sec}$.

Standardless Analysis

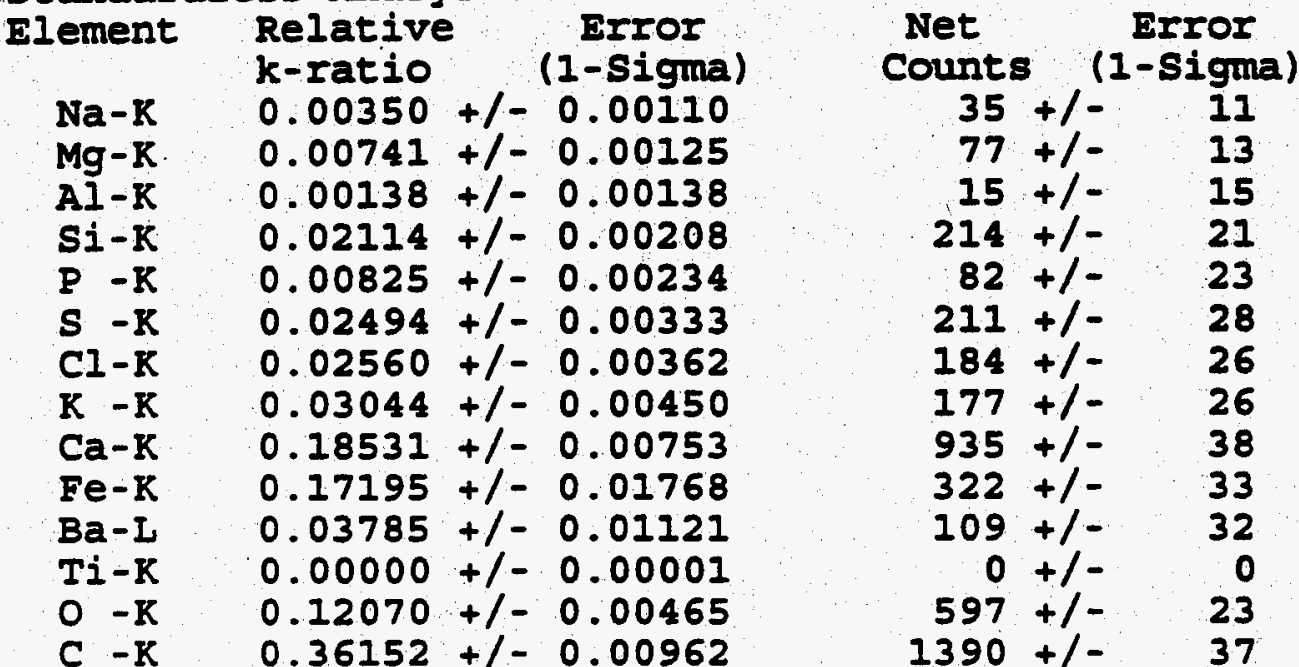

Adjustment Factors

Z-Balance:

shell:

$\begin{array}{ccc}K & L & M \\ 0.00000 & 0.00000 & 0.00000 \\ 1.00000 & 1.00000 & 1.00000\end{array}$

ZAF Correction Acc.Volt.= $15 \mathrm{kV}$ Take-off Angle=42.37 deg Number of Iterations $=5$

\begin{tabular}{|c|c|c|c|c|c|c|}
\hline $\begin{array}{l}\text { Element } \\
\begin{array}{l}\mathrm{Na}-\mathrm{K} \\
\mathrm{Mg}-\mathrm{K} \\
\mathrm{Al}-\mathrm{K} \\
\mathrm{Si}-\mathrm{K} \\
\mathrm{P}-\mathrm{K} \\
\mathrm{S}-\mathrm{K} \\
\mathrm{Cl}-\mathrm{K} \\
\mathrm{K}-\mathrm{K} \\
\mathrm{Ca}-\mathrm{K} \\
\mathrm{Fe}-\mathrm{K} \\
\mathrm{Ba}-\mathrm{L} \\
\mathrm{Ti}-\mathrm{K} \\
\mathrm{O}-\mathrm{K} \\
\mathrm{C}-\mathrm{K} \\
\text { Total }\end{array}\end{array}$ & $\begin{array}{l}\text { k-ratio } \\
\text { (calc.) } \\
0.0019 \\
0.0039 \\
0.0007 \\
0.0112 \\
0.0044 \\
0.0133 \\
0.0136 \\
0.0162 \\
0.0985 \\
0.0914 \\
0.0201 \\
0.0000 \\
0.0641 \\
0.1921\end{array}$ & $\begin{array}{l}2.185 \\
1.662 \\
1.456 \\
1.252 \\
1.211 \\
1.118 \\
1.137 \\
1.075 \\
1.065 \\
1.184 \\
1.369 \\
1.175 \\
3.985 \\
2.214\end{array}$ & $\begin{array}{r}\text { Atom } \\
0.30 \\
0.46 \\
0.07 \\
0.85 \\
0.29 \\
0.79 \\
0.74 \\
0.76 \\
4.46 \\
3.30 \\
0.34 \\
0.00 \\
27.24 \\
60.39 \\
100.00\end{array}$ & $\begin{array}{c}\text { Element } \\
\text { wt } \\
0.41 \\
0.65 \\
0.11 \\
1.41 \\
0.53 \\
1.48 \\
1.55 \\
1.74 \\
10.49 \\
10.81 \\
2.75 \\
0.00 \\
25.55 \\
42.53 \\
100.00\end{array}$ & $\begin{array}{l}\text { Wt ErI } \\
\text { (1-Sigma) } \\
+/-0.13 \\
+/-0.11 \\
+/-0.11 \\
+/-0.14 \\
+/-0.15 \\
+/-0.20 \\
+/-0.22 \\
+/-0.26 \\
+/-0.43 \\
+/-1.11 \\
+/-0.82 \\
+/-0.00 \\
+/-0.98 \\
+/-1.13\end{array}$ & $\begin{array}{c}\text { No. of } \\
\text { Cations } \\
0.266 \\
0.404 \\
0.060 \\
0.753 \\
0.258 \\
0.695 \\
0.656 \\
0.668 \\
3.932 \\
2.910 \\
0.301 \\
0.000 \\
--5 \\
53.209 \\
64.110\end{array}$ \\
\hline
\end{tabular}

The number of cation results are based upon 24 Oxygen atoms 


\section{3 .3}

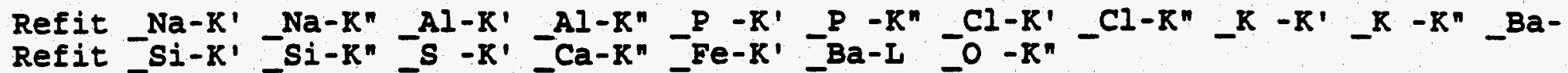
Filter Fit Method

Chi-sgd $=1.28 \quad$ Livetime $=30.0 \mathrm{sec}$.

\section{Standardless Analysis}

Element

$\begin{array}{ll} & \text { k-ratio } \quad(1-\text { Sigma) } \\ \mathrm{Na}-\mathrm{K} & 0.00221+/-0.00062 \\ \mathrm{Mg}-\mathrm{K} & 0.06803+/-0.00180 \\ \mathrm{~A} I-\mathrm{K} & 0.00418+/-0.00082 \\ \mathrm{~S} i-\mathrm{K} & 0.01402+/-0.00089 \\ \mathrm{P}-\mathrm{K} & 0.00449+/-0.00093 \\ \mathrm{~S}-\mathrm{K} & 0.03585+/-0.00250 \\ \mathrm{C} I-\mathrm{K} & 0.01015+/-0.00127 \\ \mathrm{~K}-\mathrm{K} & 0.01674+/-0.00158 \\ \mathrm{Ca}-\mathrm{K} & 0.56583+/-0.00523 \\ \mathrm{Fe}-\mathrm{K} & 0.12430+/-0.00980 \\ \mathrm{Ba}-\mathrm{L} & 0.00000+/-0.00001 \\ \mathrm{~T} i-\mathrm{K} & 0.00000+/-0.00001 \\ \mathrm{O}-\mathrm{K} & 0.05762+/-0.00146 \\ \mathrm{C}-\mathrm{K} & 0.09658+/-0.00254\end{array}$

Adjustment Factors

Z-Balance:

Shell:

$\mathrm{K}$
0.00000
1.00000

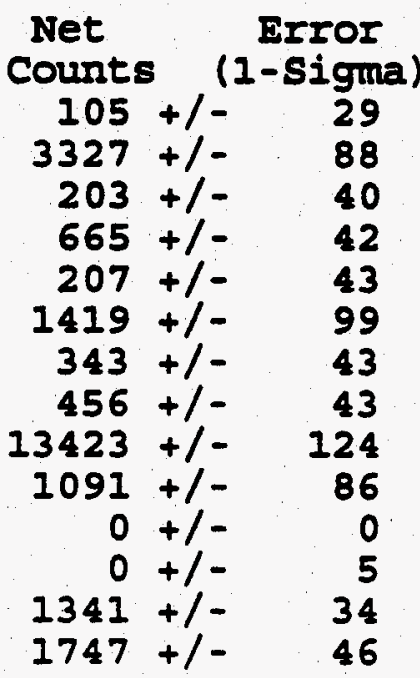

ZAF Correction Acc.Volt. $=15 \mathrm{kV}$ Take-off Angle $=42.37 \mathrm{deg}$ Number of Iterations $=5$

\begin{tabular}{|c|c|c|c|c|c|c|}
\hline $\begin{array}{l}N a-K \\
M g-K \\
A I-K \\
S i-K \\
P-K \\
S-K \\
C l-K \\
K-K \\
C a-K \\
F e-K \\
B a-I \\
T i-K \\
O-K \\
C-K \\
\text { Total }\end{array}$ & $\begin{array}{l}\text { k-ratio } \\
\text { (calc.) } \\
0.0015 \\
0.0455 \\
0.0028 \\
0.0094 \\
0.0030 \\
0.0240 \\
0.0068 \\
0.0112 \\
0.3787 \\
0.0832 \\
0.0000 \\
0.0000 \\
0.0386 \\
0.0646\end{array}$ & $\begin{array}{l}2.161 \\
1.630 \\
1.512 \\
1.281 \\
1.218 \\
1.110 \\
1.118 \\
1.011 \\
1.050 \\
1.169 \\
1.431 \\
1.232 \\
4.991 \\
2.630\end{array}$ & $\begin{array}{r}0.32 \\
7.09 \\
0.36 \\
0.99 \\
0.27 \\
1.93 \\
0.50 \\
0.67 \\
23.02 \\
4.04 \\
0.00 \\
0.00 \\
27.93 \\
32.86 \\
100.00\end{array}$ & $\begin{array}{c}\text { Element } \\
\text { wt } \\
0.32 \\
7.42 \\
0.42 \\
1.20 \\
0.37 \\
2.66 \\
0.76 \\
1.13 \\
39.74 \\
9.73 \\
0.00 \\
0.00 \\
19.24 \\
17.00 \\
100.00\end{array}$ & $\begin{array}{l}\text { Wt Err. } \\
\text { (1-Sigma) } \\
+/-0.09 \\
+/-0.20 \\
+/-0.08 \\
+/-0.08 \\
+/-0.08 \\
+/-0.19 \\
+/-0.10 \\
+/-0.11 \\
+/-0.37 \\
+/-0.77 \\
+/-0.00 \\
+/-0.00 \\
+/-0.49 \\
+/-0.45\end{array}$ & $\begin{array}{r}\text { No. of } \\
\text { Cations } \\
0.278 \\
6.094 \\
0.313 \\
0.854 \\
0.236 \\
1.657 \\
0.428 \\
0.578 \\
19.786 \\
3.475 \\
0.000 \\
0.000 \\
-.0 \\
28.238 \\
61.936\end{array}$ \\
\hline
\end{tabular}

The number of cation results are based upon 24 oxygen atoms 
$980430.3 \cdot 4$

Refit $P-K^{\prime}{ }^{P}-K^{\prime \prime} B a-I^{\prime} B a-I^{\prime \prime}-T i-K^{\prime} T i-K^{\prime \prime}$

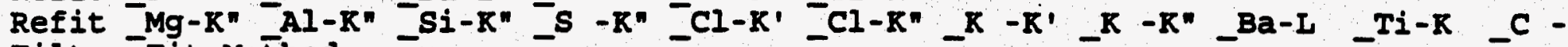
Filter Fit Method Chi-sqd $=1.68 \quad$ Livetime $=30.0 \mathrm{sec}$.

Standardless Analysis

Element

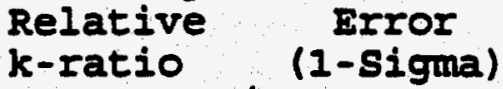

$\mathrm{Na}-\mathrm{K}$

k-ratio

(1-Sigma)

$\mathrm{Mg}-\mathrm{K}$

$0.00875+/-0.00094$

AI $-\mathrm{K}$

$0.01145+/-0.00067$
$0.01214+/-0.00067$

Si-K

$0.02444+/-0.00079$

$P-K$

$0.00199+1-0.00071$

$S-K$

$0.06054+/-0.00128$

Cl-K

$0.01490+/-0.00103$

$\mathrm{K}-\mathrm{K}$

$0.02761+/-0.00130$

$\mathrm{Ca}-\mathrm{K}$

$0.29638+/-0.00499$

$\mathrm{Fe}-\mathrm{K}$

$0.22649+1-$

0.00879

$\mathrm{Ba}-\mathrm{I}$

$0.00000+1-$

0.00001

Ti-K

$0.00000+1-$

0.00001

$\mathrm{O}-\mathrm{K}$

$0.19281+1-$

0.00290

C $-\mathrm{K}$

$0.12249+/-0.00231$

$\begin{array}{rr}\text { Net } & \text { Error } \\ \text { Counts } & (1-\text { Sigma }) \\ 639+/- & 69 \\ 870+/- & 51 \\ 916+/- & 50 \\ 1800+/- & 58 \\ 143+/- & 51 \\ 3727+/- & 79 \\ 783+/- & 54 \\ 1167+/- & 55 \\ 10932+/- & 184 \\ 3092+/- & 120 \\ 0+/- & 0 \\ 0+/- & 0 \\ 6973+/- & 105 \\ 3443+/- & 65\end{array}$

Adjustment Factors

z-Balance:

K

Shell:

0.00000

L

0.00000

$M$

1.00000

1.00000

0.00000

1.00000

ZAF Correction Acc.Volt. $=15 \mathrm{kV}$ Take-off Angle $=42.37 \mathrm{deg}$ Number of Iterations $=6$

\begin{tabular}{|c|c|c|c|c|c|c|}
\hline $\begin{array}{l}N a-K \\
M g-K \\
A I-K \\
S i-K \\
P-K \\
S-K \\
C l-K \\
K-K \\
C a-K \\
F e-K \\
B a-I \\
T i-K \\
O-K \\
C-K \\
\text { Total }\end{array}$ & $\begin{array}{c}\text { k-ratio } \\
\text { (calc.) } \\
0.0049 \\
0.0064 \\
0.0068 \\
0.0137 \\
0.0011 \\
0.0340 \\
0.0084 \\
0.0155 \\
0.1666 \\
0.1273 \\
0.0000 \\
0.0000 \\
0.1084 \\
0.0688\end{array}$ & $\begin{array}{l}2.320 \\
1.737 \\
1.500 \\
1.283 \\
1.229 \\
1.124 \\
1.148 \\
1.064 \\
1.062 \\
1.169 \\
1.371 \\
1.180 \\
3.401 \\
2.755\end{array}$ & $\begin{array}{r}1.00 \\
0.92 \\
0.76 \\
1.26 \\
0.09 \\
2.40 \\
0.54 \\
0.85 \\
8.86 \\
5.35 \\
0.00 \\
0.00 \\
46.26 \\
31.71 \\
100.00\end{array}$ & $\begin{array}{r}\text { Element } \\
\text { Wt } \\
1.14 \\
1.12 \\
1.02 \\
1.76 \\
0.14 \\
3.82 \\
0.96 \\
1.65 \\
17.69 \\
14.88 \\
0.00 \\
0.00 \\
36.85 \\
18.96 \\
100.00\end{array}$ & $\begin{array}{l}\text { Wt Err. } \\
\text { (1-Sigma) } \\
+/-0.12 \\
+/-0.07 \\
+/-0.06 \\
+/-0.06 \\
+/-0.05 \\
+/-0.08 \\
+/-0.07 \\
+/-0.08 \\
+/-0.30 \\
+/-0.58 \\
+/-0.00 \\
+/-0.00 \\
+/-0.56 \\
+/-0.36\end{array}$ & $\begin{array}{c}\text { No. of } \\
\text { Cations } \\
0.517 \\
0.475 \\
0.395 \\
0.654 \\
0.046 \\
1.243 \\
0.283 \\
0.440 \\
4.598 \\
2.776 \\
0.000 \\
0.000 \\
-.-\end{array}$ \\
\hline
\end{tabular}

The number of cation results are based upon 24 oxygen atoms 